Portland State University

PDXScholar

1993

\title{
Urban Regimes and Downtown Planning in Portland, Oregon and Seattle, Washington, 1972-1992
}

Mark Richard Bello

Portland State University

Follow this and additional works at: https://pdxscholar.library.pdx.edu/open_access_etds

Part of the Urban, Community and Regional Planning Commons Let us know how access to this document benefits you.

Recommended Citation

Bello, Mark Richard, "Urban Regimes and Downtown Planning in Portland, Oregon and Seattle, Washington, 1972-1992" (1993). Dissertations and Theses. Paper 1196.

https://doi.org/10.15760/etd.1195

This Dissertation is brought to you for free and open access. It has been accepted for inclusion in Dissertations and Theses by an authorized administrator of PDXScholar. Please contact us if we can make this document more accessible: pdxscholar@pdx.edu. 
URBAN REGIMES AND DOWNTOWN PLANNING IN PORTLAND, OREGON AND SEATTLE, WASHINGTON, 1972-1992

by

MARK RICHARD BELLO

A dissertation submitted in partial fulfillment of the requirements for the degree of

\author{
DOCTOR OF PHILOSOPHY \\ in \\ URBAN STUDIES \\ Portland State University \\ C)1993
}


TO THE OFFICE OF GRADUATE STUDIES:

The members of the Committee approve the dissertation of Mark Richard Bello presented May 7, 1993.
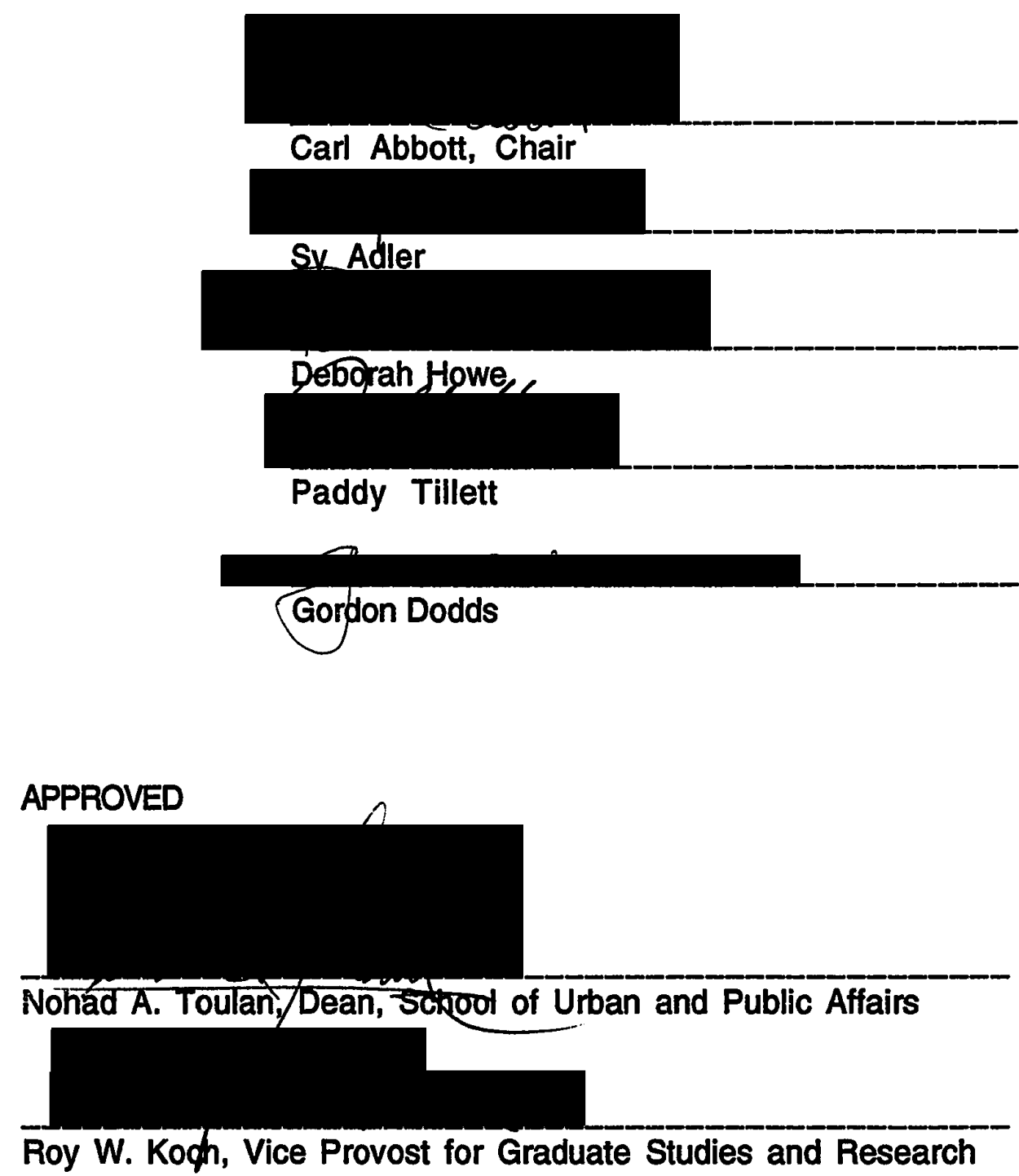
AN ABSTRACT OF THE DISSERTATION OF Mark Richard Bello for the Doctor of Philosophy in Urban Studies presented May 7, 1993.

Title: Urban Regimes and Downtown Planning in Portland, Oregon and Seattle, Washington, 1972-1992.

APPROVED BY THE MEMBERS OF THEDISSERTATION COMMITEE

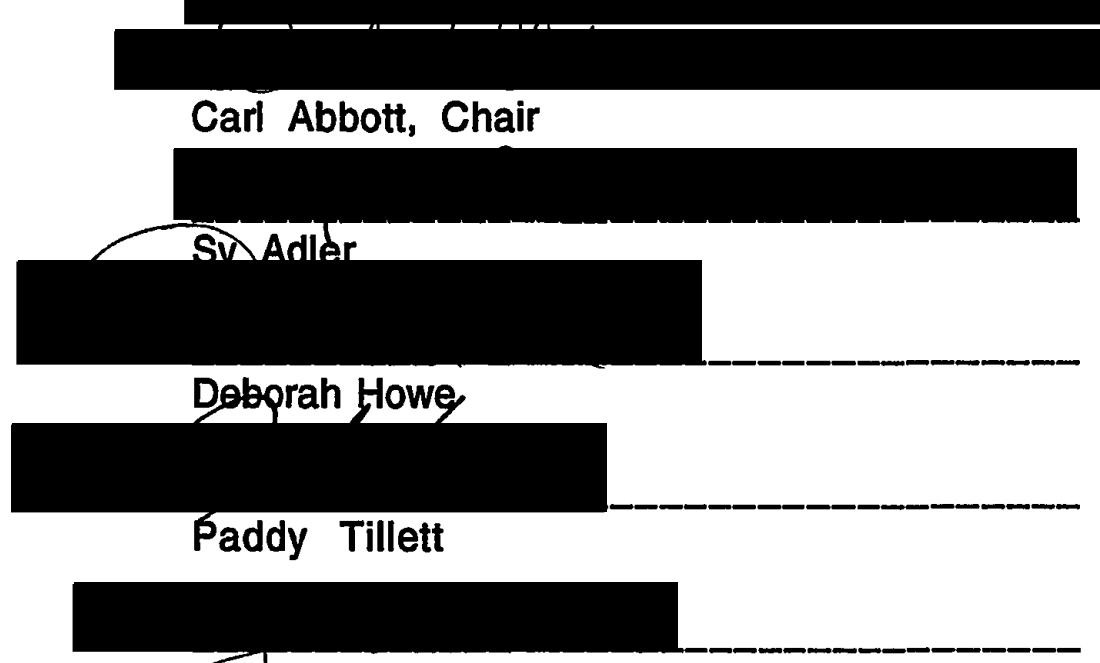

Gordion Dodds

Portland and Seattle are often considered to be divergent in character, partly because civic leadership in each city has a different vision. The adoption of contrasting downtown core plans, projects, and policies in each city allows us an opportunity to understand the nature of each city's regime. As defined by Elkin, an urban regime is the community's governing coalition, those who exercise public authority in a legal sense and those private actors able to act collectively and bring concerted influence to bear. 
The time frame for this study begins with the first modern planning document, the 1972 City of Portland Downtown Plan. During this period, both central business districts were transformed, simultaneously losing some retail, commercial and industrial functions while gaining further control of regional economies.

Portland perfected the entrepreneurial urban regime. The linkage among the land use alliance (property owners, investors and private professionals); the bureaucracy; and politicians was established by the success of the 1972 Downtown Plan. There is little conflict in Portland. Systemic bias is masked by overly extensive citizen involvement processes; city subsidies and grants which influence activists' positions; and use of tax increment money to hire consultants who reinforce the business point of view.

Seattle never perfected the entrepreneurial regime. The business community was fractured into conservatives and progressive camps. Also, the bureaucracy was caught in the Mayoral-Council crossfire. There is great controversy in Seattle. The prodevelopment decisions are still made but activist groups can successfully make it to the ballot box.

Primary sources of information included planning studies; reports; memoranda; minutes of meetings; resolutions; budgets; and activists' printed materials. Participants in each city were interviewed. Secondary sources of information included articles, and census materials. 


\section{ACKNOWLDGEMENTS}

Good citizens are the riches of these cities.

Thanks to my family. 
TABLE OF CONTENTS

PAGE

ACKNOWLEDGEMENTS. ............................ i i

LIST OF TABLES. ........................... ix

LIST OF FIGURES. . . . . . . . . . . . . . .

CHAPTER

I INTRODUCTION...........................

Endnotes : ........................10

II PORTLAND AND SEATTLE: POLITICAL ARRANGEMENTS

AND POLICY FORMATION . . . . . . . . . . . . . . . . . . 11

The impact of postwar growth . . . . . . . . . 13

Politics .........................23

Postwar Reform Politics in Portland

Reform Politics in Seattle

Continuing Political Evolution in Portland

Mid-Sixties Challenges in Seattle

Downtown Activism in Portland

Neighborhood Activism in Seattle

Comparison

Socioeconomic Context . . . . . . . . . . . . . . .43

Geography and Group Influence. . . . . . . . . . 48

"Zones of Discard"

Newer Reinvestment Areas

Manufacturing and Wholesale Trade 
Theoretical Questions . . . . . . . . . . . . . . . . . . 54

Pluralism

City Limits

Urban Regimes

Stratification

Endnotes .........................66

III PORTLAND: FROM DOWNTOWN PLAN TO CENTRAL CITY

PLAN...............................70

New Challenges. .....................70

Central City Plan: Updating the Downtown

Plan .............................71

Process

Critical Issues

Balanced Representation

Plan Purpose

Design Event One

Functional Advisory Committees

New Actors: the Urban Design

Advisory Team

Overload

Phase Two

Housing

The Planning Bureau Takes Charge . . . . . . . . . . 96

Planning Outcomes ................. 107

Downtown

North of Burnside

Lloyd District

Northwest Triangle and Macadam

Central Eastside

Conclusion . . . . . . . . . . . . . . . . 110

Endnotes. ......................118 
IV SEATTLE DOWNTOWN PLAN ...............123

Postwar Optimism . . . . . . . . . . . . . . . . 123

Monson Plan. . . . . . . . . . . . . . . . 123

Land Use and Transportation Plan (LUTP) . . . . 129

Plan Policies. . . . . . . . . . . . . . . . . . . . . . . . . 142

Housing

Urban Design

Arts

Office and Commercial Concentration

Retail

Peripheral Residential Areas

Incentives

Citizen's Alternative Plan . . . . . . . . . . . . . . 150

Conclusion . . . . . . . . . . . . . . . . . . . 159

Endnotes . . . . . . . . . . . . . . . . 165

V PORTLAND MORRISON STREET PROJECT. . . . . . . . . 167

Cadillac-Fairview. . . . . . . . . . . . . . . 167

Opposition

Demise of Cadillac-Fairview

Rouse Enters the Scene . . . . . . . . . . . . . . . . 183

Selection

Re-negotiation

Opening . . . . . . . . . . . . . . . . ...197

Conclusion. . . . . . . . . . . . . . . . . . . ..199

Endnotes . . . . . . . . . . . . . . . . . . . . . . . . . .204 
VI SEATTLE WESTLAKE MALL PROJECT. . . . . . . . . . . 208

Early Struggles. . . . . . . . . . . . . . . . .208

Mondev .........................215

Opposition

Royer's Revision

Demise of Mondev/Seattle Art Museum

Proposal

Rouse Enters the Scene . . . . . . . . . . . . . ..226

Continued Opposition

The "Battle of Westlake"

Conclusion. . . . . . . . . . . . . . . . . ...235

Endnotes . . . . . . . . . . . . . . . . . . . . ..239

VII FROM SKID ROAD TO NORTH DOWNTOWN. ...........246

Dowrtown Plan. . . . . . . . . . . . . . .246

Implementation of the Downtown Plan . . . . . ..250

1981 North of Burnside Study

Mid-1980's Conflicts

Mayor Clark's 12-point Plan

The Clark-Shiels Agreement. . . . . . . . . . . . 266

Central City Plan Policy Reversal. . . . . . . . . . . .272

The Burnside Community Council Closes

Challenge to PDC. . . . . . . . . . . . . . . . . 277

River District Proposal. . . . . . . . . . . . . . . . .278

Conclusion. . . . . . . . . . . . . . . . . . . ...280

Endnotes. .........................285 
viii

\section{RESIDENTIAL DISPLACEMENT IN DOWNTOWN}

SEATTLE $\ldots \ldots \ldots \ldots \ldots \ldots \ldots \ldots \ldots \ldots \ldots \ldots$

Community Reaction to Increasing

Displacement. . . . . . . . . . . . . . . . . .287

Housing Preservation Ordinance . . . . . . . . . .293

Rent Control

Land Usa aild Transportation Plan Housing

Policy.............................296

Mayor's Recommended Draft

Court Invalidates HPO

Business Commitment

Citizens' Alternative Plan Challenge. . . . . . . . . ..309

Conclusion.........................314

Endnotes .......................... 319

IX CONTRASTS IN URBAN REGIMES. .................321

How the Urban Regimes Operate. . . . . . . . ...321

Portland

Seattle

Why the Portland Urban Regime is More

Successful .........................329

Summary: Lessons from Seattle and Portland. . 337

Directions for Further Research. . . . . . . . . . 342

Endnotes. .......................348

REFERENCES $\ldots \ldots \ldots \ldots \ldots \ldots \ldots \ldots \ldots \ldots \ldots \ldots \ldots \ldots \ldots \ldots \ldots \ldots$

APPENDIX $\ldots \ldots \ldots \ldots \ldots \ldots \ldots \ldots \ldots \ldots \ldots \ldots \ldots \ldots \ldots \ldots \ldots \ldots . . .388$ 


\section{LIST OF TABLES}

TABLE

PAGE

I Metropolitan Population Growth: United States, Portland and Seattle. . . . . . . . . . . . . . . . 16

II Population Growth in Portland and Seattle Central Cities and Surrounding Counties: 1970-1990. . . . . . 18

III Percentage Employment Mix By Region, 1970 - 1990. . 19

IV Percentage City Core Employment Mix, Portland and Seattle: $1970-1980 \ldots \ldots$. . . . . . . . . . . . . . . 21

V Selected Population Characteristics, Portland and Seattle: 1980 and 1990. . . . . . . . . . . . . 44

VI Selected Population and Housing Characteristics, Portland Downtown and Seattle Downtown, 1990. . . . .46

VII LUTP Density Limits. . . . . . . . . . . . . . . . . . . . . . 148

VIII Source of Anti-CAP Funding By Interest Groups . . . . . 157

IX Source of Anti-CAP Funding

By Individual Contributors. . . . . . . . . . . . . . 158 


\section{LIST OF FIGURES}

FIGURE PAGE

1. Isometric View of Downtown Portland. . . . . . . . . 2

2. Isometric View of Downtown Seattle. . . . . . . . . . 3

3. Case Studies Timeline. . . . . . . . . . . . . . . . 7

4. How a City's Policies Are Determined. . . . . . . . . . . 12

5. Metropolitan Portland and Seattle. ............ 14

6. Downtown Plan Concept. .................. 35

7. Portland Historic Development. . . . . . . . . . . . 50

8. Seattle Historic Development. . . . . . . . . . . . . . .51

9. Systematic Bias. ......................64

10. Neighborhood and Business Association Boundaries. . . . 73

11. Central City Concept Diagram, George Crandall. . . . . . .91

i2. Central Commercial Arc. ................... 100

13. Eastbank Freeway Options. . . . . . . . . . . . . . . 103

14. Central City Plan Concept. . . . . . . . . . . . . . 108

15. Research Questions: Central City Plan. . . . . . . . . .112

16. Monson Plan Sketch. ...................... 125

17. Seattle 2000 Downtown Areas. . . . . . . . . . . . 130

18. Skyline Views from West Seattle. . . . . . . . . . . . . 134

19. Downtown Classifications and Heights. . . . . . . . 143

20. Washington Mutual Tower Floor Area Bonuses. . . . . . .153

21. CAP Height Limits. . . . . . . . . . . . . . . . 156 
22. Research Questions: Land Use and

Transportation Plan. . . . . . . . . . . . . . 161

23. Morrison Street Project Site. . . . . . . . . . . . . 168

24. Morrison Street Project Site Land Use. . . . . . . . . . 172

25. Cadillac Fairview Skybridges. . . . . . . . . . . . 175

26. Revised Pioneer Place Concept Proposal. . . . . . . . . 192

27. Research Questions: Morrison Street Project. . . . . . .200

28. Westlake Vicinity Map. ..................211

29. Westlake Park Project Proposal, 1974. . . . . . . . . . 214

30. Mayor Royer's Westlake Proposal, 1978. . . . . . . 221

31. Private Public Space vs. Public Public Space at Westlake............................. 227

32. Rouse Proposal with Wintergarden. . . . . . . . . . . . . 229

33. A Town Square Park Alternative for Seattle at Westlake. . . . . . . . . . . . . . . . . . . . . . . .234

34. Research Questions: Westlake Mall. . . . . . . . . . 236

35. Union Station, Railyard Planning District. . . . . . . . . . 248

36. Northwest Industrial Planning District and Railyard/Post Office Planning District. . . . . . . . . . . 249

37. North of Burnside Land Use Policy: . . . . . . . . . . . .257

38. Location of SRO's or Shelters North of Burnside. . . . . 262

39. Central City Floor Area, 1988. . . . . . . . . . . 273

40. North Downtown Redevelopment Opportunities, 1990. 279

41. Research Questions: Skid Road to North Downtown. . . 281

42. Seattle Downtown Residential Neighborhoods. . . . . . . .289

43. Downtown Low Income Program ............. 304 


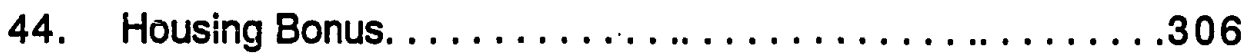

45. Research Questions: Residential Displacement in Downtown Seattle. . . . . . . . . . . . . . . . . . 316

46. Portland: Urban Renewal, Redevelopment and Downtown Plan Special Districts. . . . . . . . . . . . 339 


\section{CHAPTER I}

\section{INTRODUCTION}

When we view the adoption of contrasting downtown core plans, projects, and policies in Portland and Seattle, we view the contest between effectiveness and democracy. City bureaucracies and business organizations in these two very similar Northwest cities have attempted to structure public debate and decisions to their mutual advantage and to the disadvantage of social and environmental activists.

This dissertation examines the two decades from 1972 to 1992, when each city had already rejected the clearance of its core and sought a new strategy to revitalize that core. Figures 1 and 2 illustrate mid-1980s views of each city's core. During this period, both central business districts were threatened with the loss of retail, commercial and industrial functions to an expanding metropolis. Each city realized that it must plan its downtown, encourage office growth, retain some retail, and prevent the further erosion of downtown housing. Both cities sought out experts who could explain how to modernize the core and retain a central role within decentralizing metropolitan areas. Citizens of both cities objected to proposed freeways, to demolition and clearance of historic districts, and to loss of downtown housing. Freeways were stopped, historic districts designated, housing built downtown, and 


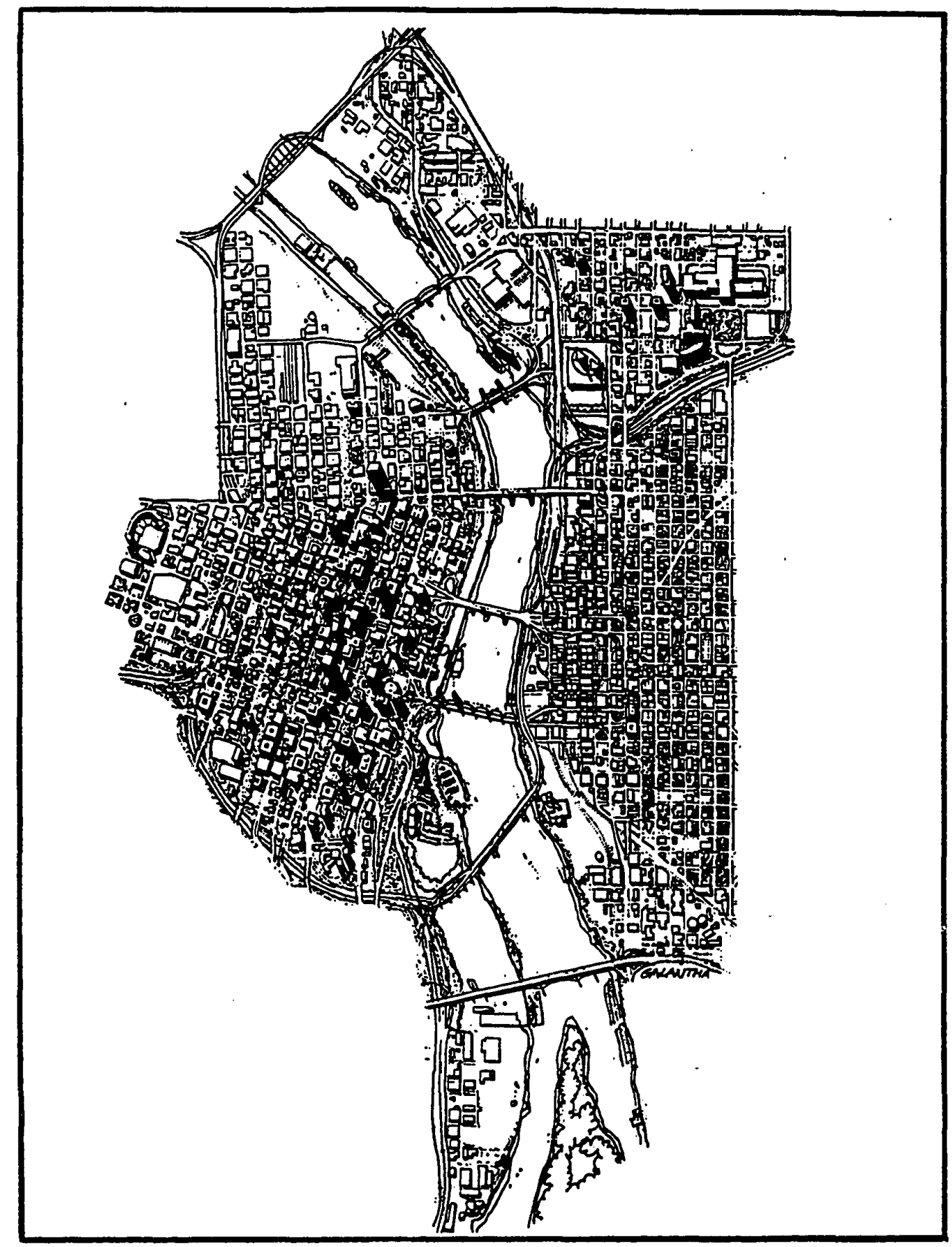

Figure 1. Isometric View of Downtown Portland. From City of Portland, Developer's Handbook, (1992). 


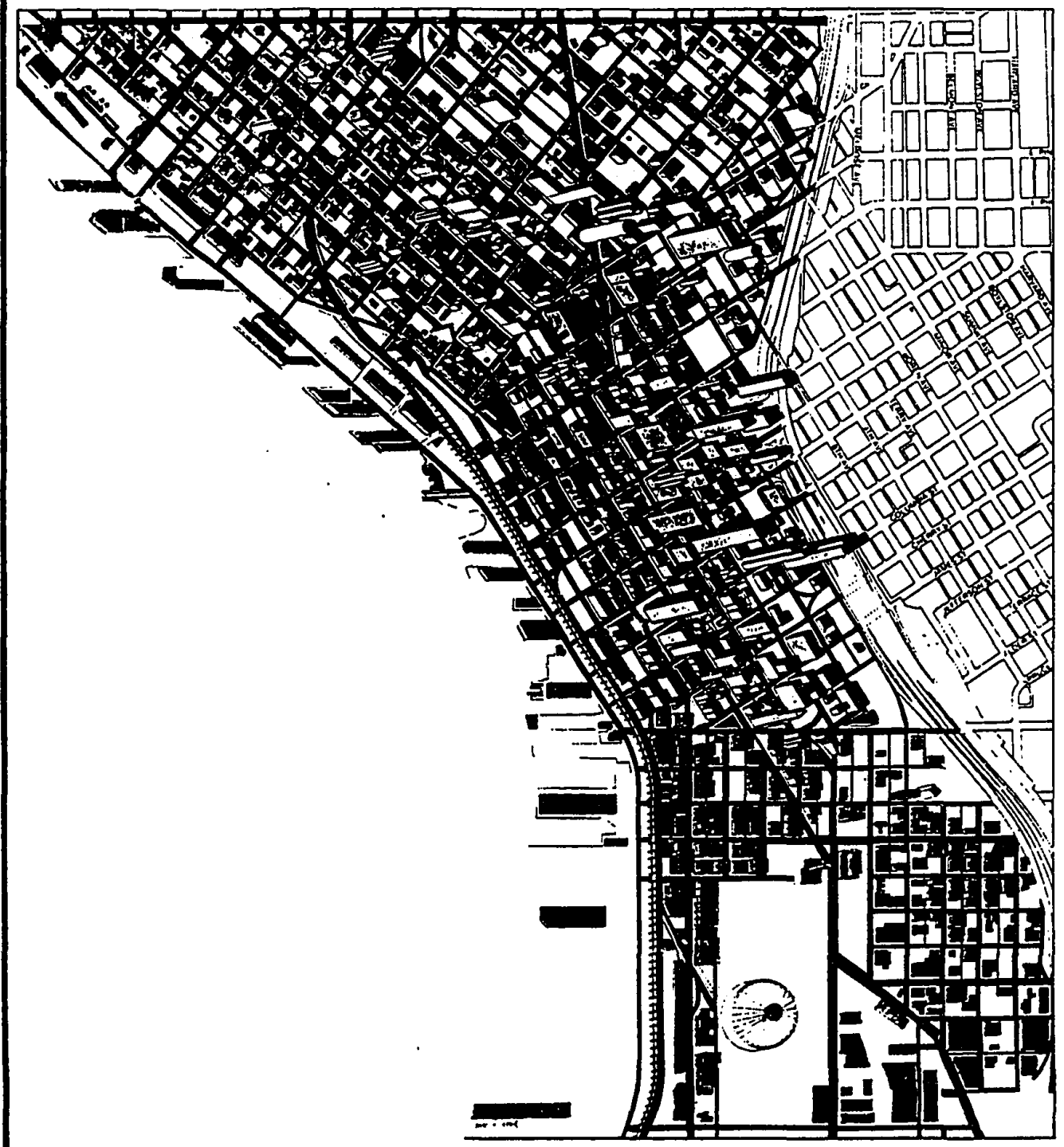

Figure 2. Isometric View of Downtown Seattle. From City of Seattle, Summary of the Land Use and Transportation Plan for Downtown Seattle (1985). 
retail cores strengthened. Although both downtowns lost market share to outlying retail, commercial and industrial areas, they simultaneously maintained dominance in headquarters office space and upscale retailing. However, historical sketches in Chapter II describe a divergence in the level of conflict and the role of local government in the 1970s. Portland had embarked upon extensive urban renewal in the early 1960s, but within a decade paused to create a Downtown Plan. The 1972 Downtown Plan took almost a decade to implement. The Plan guided the actions of the private sector and the city's Development Commission so successfully that an update was begun in the mid-1980s. The Downtown Plan's success ensured acceptance of a plannerly process-oriented approach. Portland had created a process-oriented, low conflict political style which contained opposition to the well-entrenched City Hall and downtown business interests coalition. The Portland Development Commission became a dominant player. Activists were absorbed or dropped out. Seattle undertook one project after another, from the world's fair in 1962, to the clean-up of Lake Washington in the mid-1960s and 1970s, to the creation of an impressive downtown in the 1980s. Seattle built these projects at the cost of increasing conflict and increasing estrangement between activists and City Hall. Seattle lacked a coordinating mechanism to make agreements stick. Activists turned to alternative forms of leverage such as ad hoc electoral coalitions rather than continue fruitless negotiations with downtown interests. In the late-1980s, Seattle voters adopted a limited lid on downtown development. 
Chapter II also describes an activist local government in Portland which endured as Seattle faltered. While Seattle failed to implement urban renewal programs on the downtown periphery, Portland extended urban renewal from the fringe to the heart of downtown. While Seattle failed to address the increasing congestion of freeways leading downtown, Portland built the first leg of a radial light rail system and has begun work on a second leg to connect downtown with the wealthiest suburbs. Portland promoted development through a independently financed Development Commission which has no counterpart in Seattle. 1 For two decades Portland pursued downtown growth at the expense of alternative uses of tax revenue. The use of tax increment financing insulated the use of tax revenue for downtown project from other city needs. This policy was not challenged until caught in a statewide tax revolt in the early 1990s, and downtown growth remains a regional objective. Portland also institutionalized city design review as a means to further development objectives by insuring quality development appropriate to the status of the region's headquarters. ${ }^{2}$ In Seattle, downtown growth was successfully challenged by the public. It is the goal of this study to examine the reasons behind these contrasting records.

Past history, politics and external events affect decisionmaking as well. Both cities have been affected by great postwar growth, and increased sophistication of government, business associations, neighborhoods and specific interest activists. The crucial distinction between these two cities is institutional. The 
difference lies in both formal governmental institutions and informal arrangements between organized groups which have adapted to modern times. Portland's political arrangements have enhanced the ability of business and City Hall to form an alliance in contrast to Seattle where more pluralist politics have created competitive issues. In cities like Portland and Seattle, where political parties are not significant actors in municipal politics, the institutions which structure public debate and provide continuity are the bureaucracies and downtown business associations.

Contrasting political arrangements in each city allow us an opportunity to understand the nature of each city's governing coalition or "urban regime." As defined by Stephen Elkin, an urban regime is the community's governing coalition, those who exercise public authority in a legal sense and those private actors able to act collectively and bring concerted influence to bear. ${ }^{3}$ Private and public investment decisions are coordinated by urban regimes. We can trace the impact of the urban regime on public and private decisions and the resulting transformation of each city during the preparation and implementation of core plans and projects in the 1970 s and 1980s. Outcomes represent the bargaining, conflict, and consensus among various factions who are unequally positioned. The time line presented in Figure 3 illustrates the continuity of policy in Portland. A break in policy is indicated by a displacement of the line. For example, the sole reversal of public policy in Portland is represented by the break between the Cadillac-Fairview project and the Rouse project. The strong impact of the Downtown Plan is 


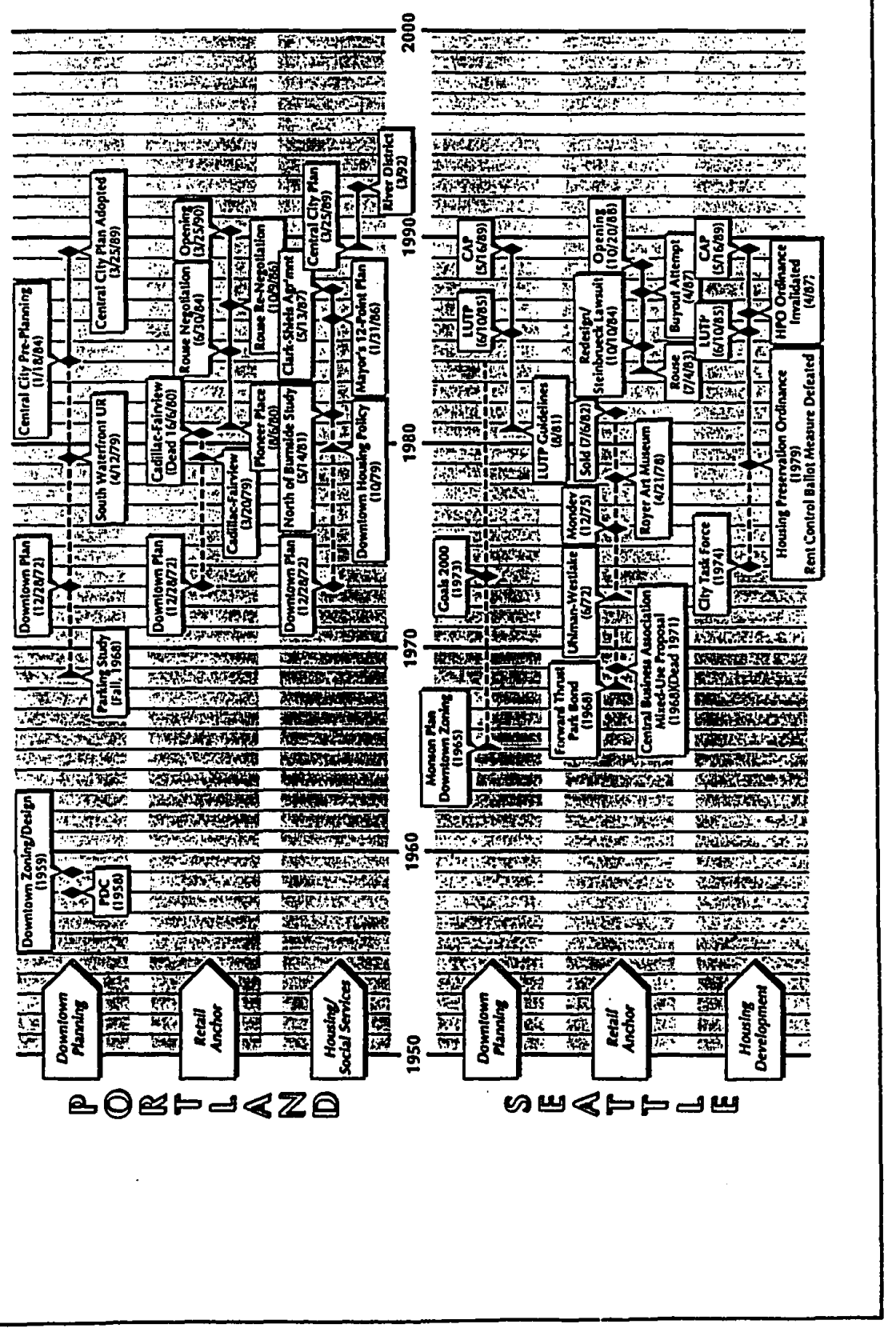

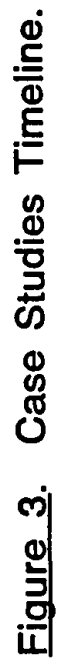


evident in Portland. In contrast, Seattle development is marked by pronounced discontinuities.

This study is organized around the story of formal decisionmaking processes rather than electoral politics. ${ }^{4}$ It will describe how Portland perfected an entrepreneurial urban regime and how the urban regime dealt with conflict in three specific projects, plans and policies. The linkage among the land use alliance (property owners, investors and private professionals), the bureaucracy and politicians was established by the success of the 1972 Downtown Plan. There is little conflict in Portland. Systemic bias is masked by overly extensive citizen involvement processes, city subsidies and grants which influence activists' positions, and use of tax increment money to hire consultants who reinforce the business point of view. Seattle never perfected the entrepreneurial regime. The business community was fractured into conservative and progressive camps. Also, the bureaucracy was caught in the Mayoral-Council crossfire. There is recurring, bitter controversy in Seattle. The prodevelopment decisions are still made but activist groups can successfully challenge at the ballot box.

Chapter II provides theoretical tools to understand the outcomes of plans and projects narrated in Chapters III through VIII. The Chapter discusses competing reasons for the difference in regime effectiveness. Postwar growth and governmental activism set the stage for the formation of stratified urban regimes. Three research questions are posed as a means to discuss the potential for activist success. The next six chapters explore three types of plans 
or projects in each city. Chapters III and IV chronicle the Portland Central City Plan/Downtown Plan update and the Seattle Land Use and Transportation Plan effort. Chapters V and VI describe efforts in both cities to develop downtown retail projects. Chapters VII and VIII describe attempts to grapple with the provision of housing and social services for the poor in each downtown. The concluding chapter, Chapter IX, attempts to compare and contrast downtown politics. Portland has traded democracy for effectiveness. Seattle's pluralist inclinations have hindered effectiveness but allowed the articulation of alternative visions for the city. 


\section{ENDNOTES}

${ }^{1}$ Tax increment financing assigns the revenue generated above the adopted base year to a development agency for use on projects within an urban renewal district. Approval of Measure 5, a property tax limitation, has seriously affected the ability of PDC by bringing tax increment revenue within a property tax cap. However, this limitation was an inadvertent result of the larger failure of the Oregon tax system and its over reliance on the property tax. The city is now considering measures to ask the voters to reinstate this system.

${ }^{2}$ Although design review seeks to further human scale design, the author feels that it is supported by the downtown business community for the upscale status it ensures.

3"Urban regime" is a term coined by Stephen L. Elkin. See Stephen L. Elkin, City and Regime in the American Republic, Chicago: The University of Chicago Press, 1987. Elkin and other theorists are discussed in Chapter II.

4The opportunity to evaluate the experience of the Rouse Corporation's retail projects in both cities provided the impetus for this study. The focus then expanded to include the downtown planning environment represented by each city's downtown plan. I was also interested in the Impact of redevelopment. Redevelopment causes both small retailer and housing displacement. I selected the latter because housing displacement was a primary concern of those activists who challenge the downtown urban regime. This dissertation was written first as a chronology of events in Portland and Seattle. Interviews and written documents such as planning studies and reports provided a means to isolate significant events. Other primary documents included memoranda, minutes of each meeting, resolutions, budgets, etc. Secondary sources of information included newspaper and magazine articles, and census materials. These materials were avallable from the City of Portland and City of Seattle archives; the Multnomah County library and Portland State University library and the City of Seattle library and Seattle Municipal library; and individuals and government agencies. Bias is a danger in such research as this. To avoid bias, chapters were reviewed by knowledgeable but disinterested participants such as Paddy Tillett, who was a member of the Urban Design Advisory Team for the Central City Plan in Portland and who practices architecture in Portland and Seattle; and Brewster Denny, professor of public administration at the University of Washington in Seattle. I also benefitted from the long-standing involvement of my sources who are at least consistent in their biases and provide a constant point of view of these events. The danger of blas was also mitigated by the nature of my findings. At the beginning of this study 1 was newly assigned to downtown reviews at the City of Portland Bureau of Planning. This research and my personal experience have led me to conclude the opposite of my colloquium proposal when I mistook lack of conflict in Portland for true citizen participation. 


\title{
CHAPTER II
}

\section{PORTLAND AND SEATTLE: POLITICAL ARRANGEMENTS AND POLICY FORMATION}

\begin{abstract}
Informal and formal political arrangements most directly affect planning processes. These processes are more democratic or more elitist (and presumably more decisive). This study focuses on the interrelationship between informal and formal political arrangements and planning outcomes. Figure 4 illustrates this model of urban politics. Community socioeconomic characteristics indirectly affect a city's policy. External events and previous community decisions even more indirectly set the stage. This chapter describes postwar growth, downtown politics and general socioeconomic characteristics to make the argument that these more fundamental characteristics were shared by Portland and Seattle at the beginning of the study period. Both cities were economically successful, middle-class cities, which championed similar development agendas Yet they diverged during the study period. As sketched out in Chapter I, Portland implemented and continues to implement a energetic downtown development agenda. Seattle's agenda has been thwarted by successful appeals to the voters. At the end of the chapter, we examine pluralist and revisionist theory in order to understand the interaction between group influence, political institutions and policy selection. Three
\end{abstract}




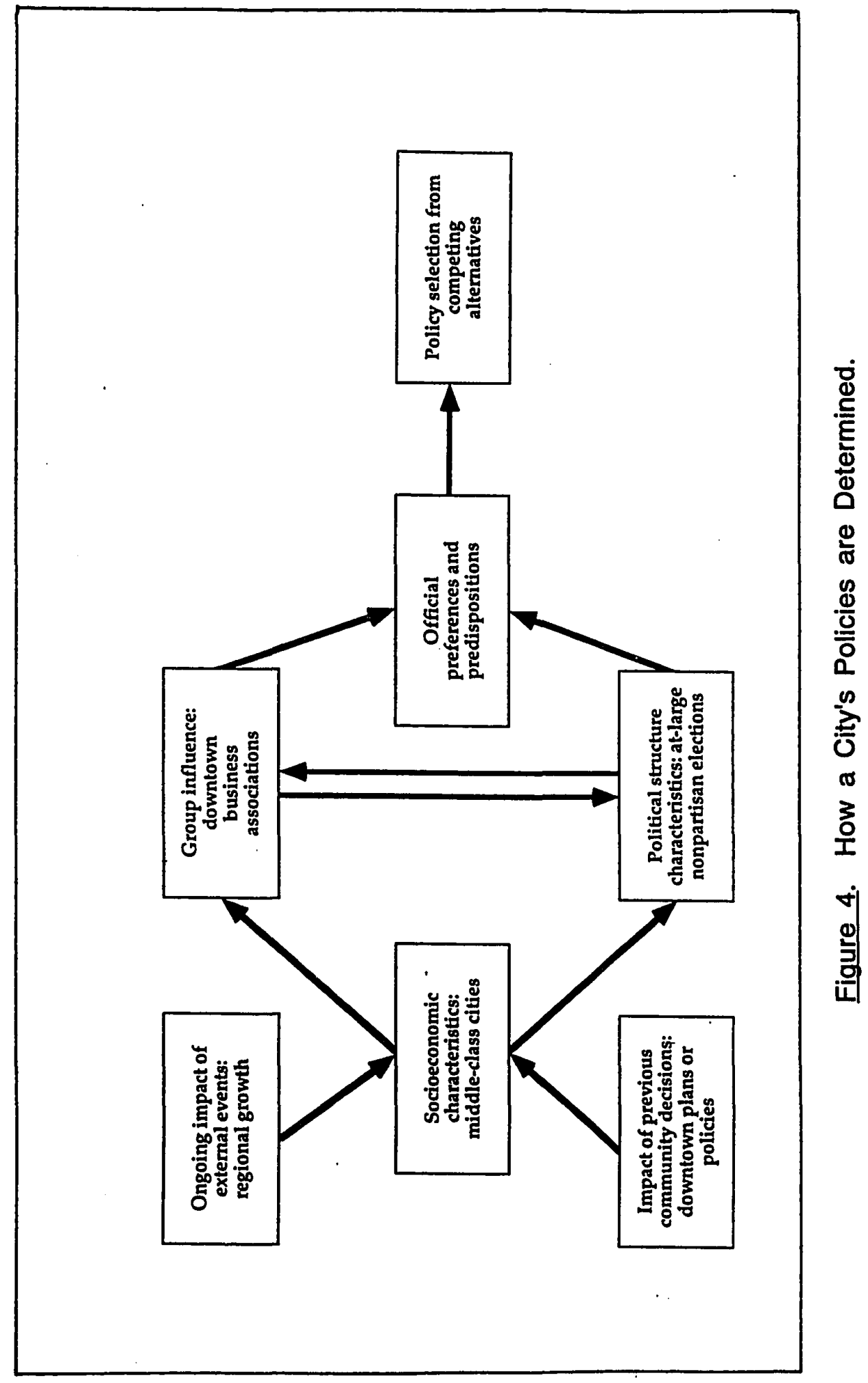


research questions are developed to provide a framework for our six case studies. Answers to these three research questions will provide a description of the urban regime in each city and the balance each city has created between democracy and effectiveness.

\section{THE IMPACT OF POSTWAR GROWTH}

Using 1950 data, Otis Duncan and his colleagues described a national classification scheme which placed 151 metropolitan areas in a national hierarchy based upon population and economic functions. The system defined the categories of national metropolis, regional metropolis, regional capital, diversified manufacturing center with and without metropolitan functions, and special cases. New York, Chicago, Los Angeles, Philadelphia and Detroit ranked high in population, value added by manufacture, wholesale sales, business services receipts, non-local commercial loans and demand deposits. Portland and Seattle ranked 20th and 21st in metropolitan population. These two cities were "alike in being centers of commercial activity and nodal points for rather extensive hinterlands over which they enjoy uncontested dominance."1 The Seattle and Portland economies-were based on the Pacific Northwest resource industries. (Figure 5 illustrates the location and extent of these two metropolitan areas.)

Since 1950, both cities have become integrated into the global economy. The regions are caught up in foreign trade and foreign competition. The manufacturing sector has been enlarged to include electronics and computers. In both cities retail and manufacturing 


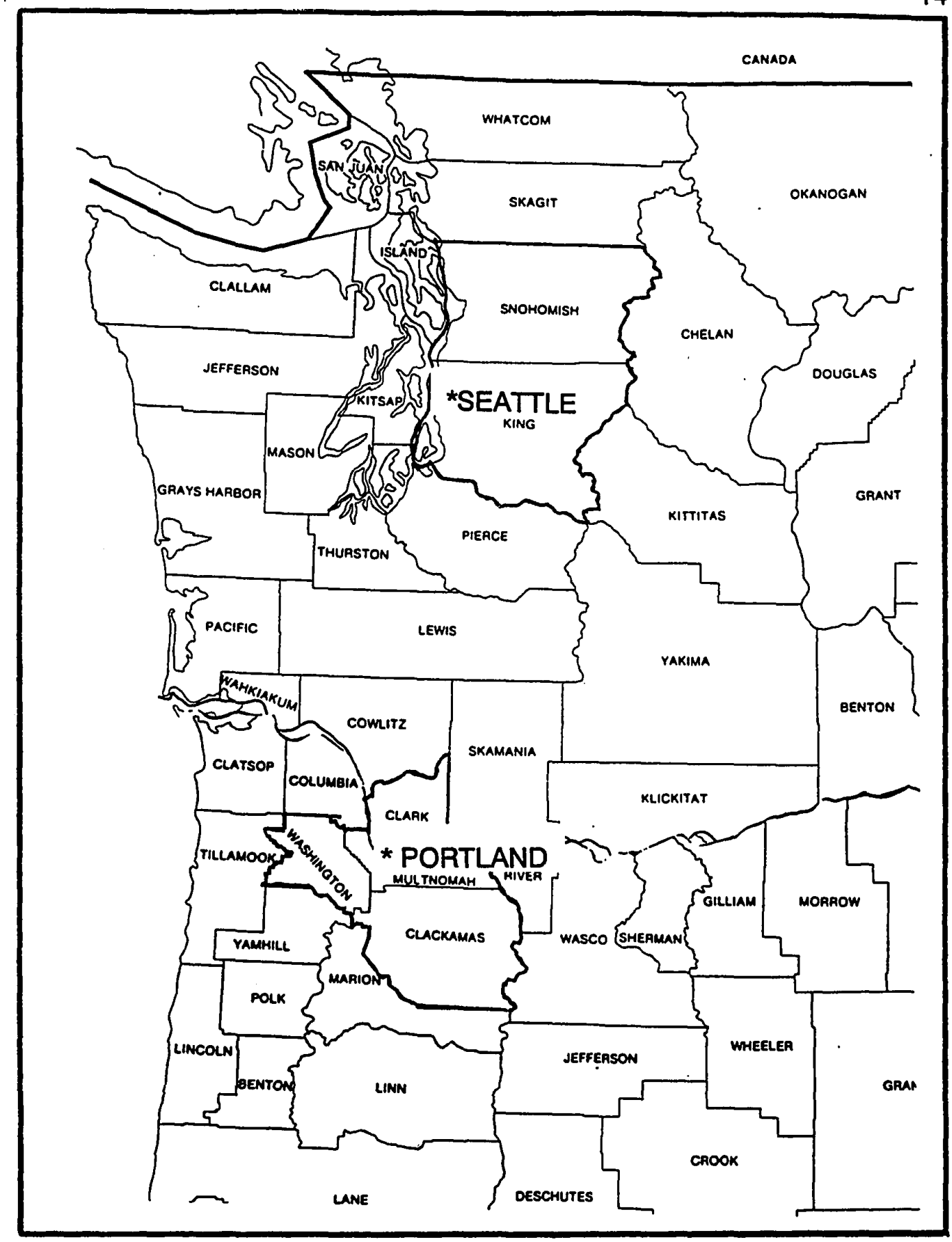

Figure 5. Metropolitan Portland and Seattle. 
jobs are locating outside the core, but downtown remains the predominant office center.

Seattle's office spurt in the late 1980 s convinced many that Seattle had left the league of regional centers for an international role. However, the City of Seattle itself could not make that case. Seattle, like Portland, is not a major financial center, being far outdistanced by Vancouver, B.C. and San Francisco.2 Furthermore, much of the increasing statistical gap in population between Seattle and Portland is the result of combining the Seattle/Everett and Tacoma metropolitan areas for census purposes. Seattle metropolitan counties grew 38.5 percent from 1970 to 1990 to $1,972,961$ but this was less than the 40.2 percent growth rate in Portland (reaching 1,412,374 in 1990.)

Table I indicates United States and Portland and Seattle metropolitan population growth since 1940. Both regions gained approximately 40 percent in metropolitan population from 1940 to 1950 as the result of war inmigration, then traded population leads over the next several decades. Both metropolitan regions have grown considerably faster than the United States. In the 1950's Seattle grew close to the national rate (31.1 percent vs. 33 percent while Portland lagged (16.7 percent). In the 1960's, both Portland and Seattle got close to the rate for all U.S. metropolitan areas (22.5 percent and 28.7 percent vs. 23.5 percent U.S.) During the study period, 1970 - 1990, first Portland, then Seattle grew twice as fast as the national rate. In the 1970's Portland grew at a 23.4 percent rate while the U.S. grew at a 10.7 percent rate. In the 1980 s, 


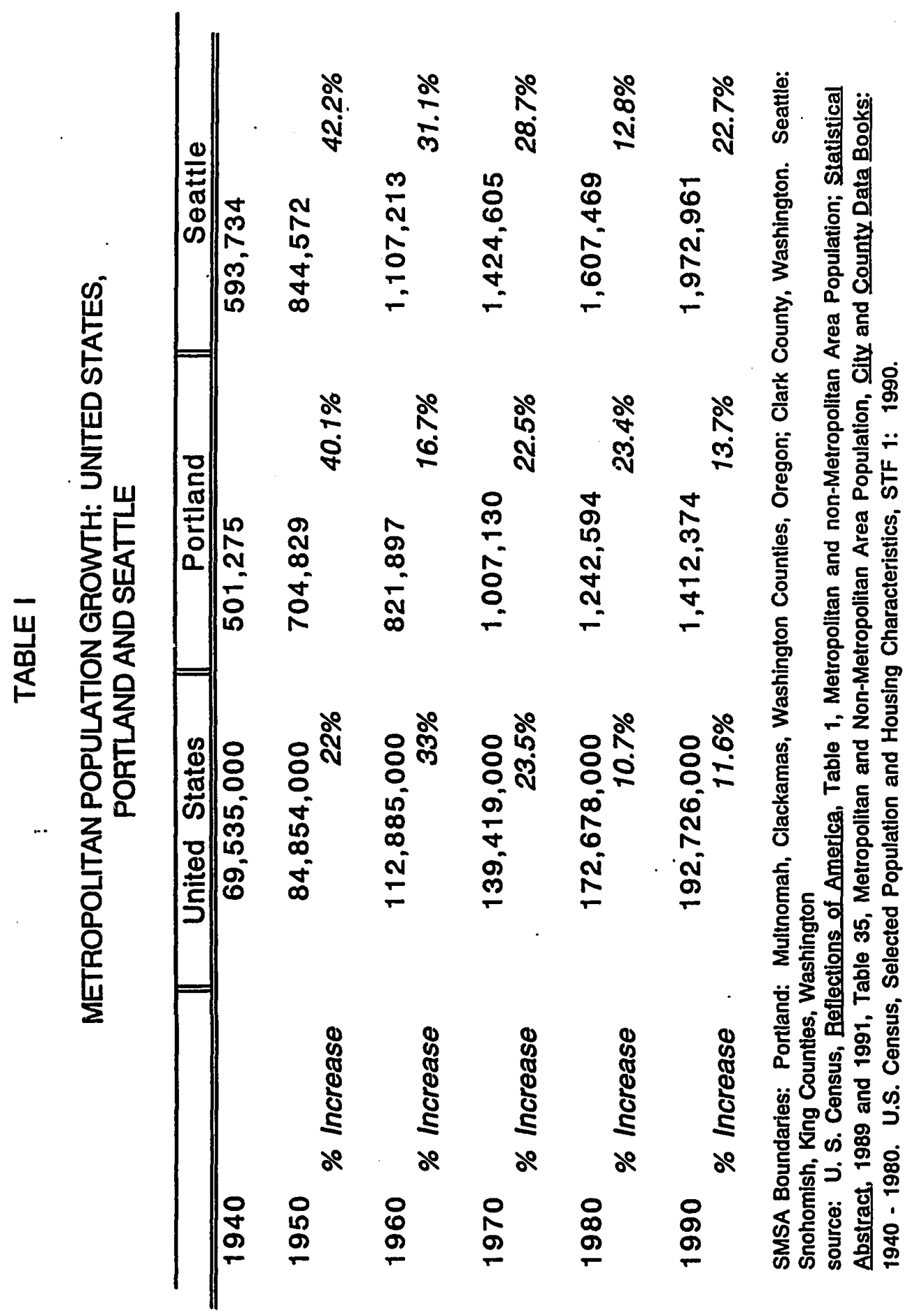


Seattle grew at a 22.7 percent rate vs. the U.S. rate of 11.6 percent. As mentioned above, both regions grew approximately 40 percent over the two decades of our study period. The study period was a period of great metropolitan expansion in both regions compared to the U.S.

Both central cities experienced a declining share of regional growth in the last two decades. Table II compares central city population to the same surrounding suburban counties regardless of Census definition of metropolitan areas. ${ }^{3}$ Each city declined from approximately 37 percent of its region in 1970 to 30 percent a decade later. In the 1980s, Portland managed to temporarily halt its proportionate decline by annexing approximately five percent of the region's population, rising to 31 percent of the region's population. Seattle declined to 26.2 percent of the region. Rapid population growth has been fueled by an average annual 2 percent plus increase in employment in the 1970's and 1980's. This growth rate is projected to continue through the year 2000 in both regions. 4

Portland and Seattle both managed to retain manufacturing jobs despite the national shift to FIRE (finance, insurance, and real estate), services and retail and wholesale trade. In Portland, manufacturing employment lost in the 1981-1983 recession was not regained until the end of the decade. In Seattle, Boeing maintained a strong presence. Boeing's plants south of the CBD and in Everett and the suburbs accounted for $\mathbf{4 0}$ percent of all regional manufacturing employment. Table III indicates the mix of industry in the United 


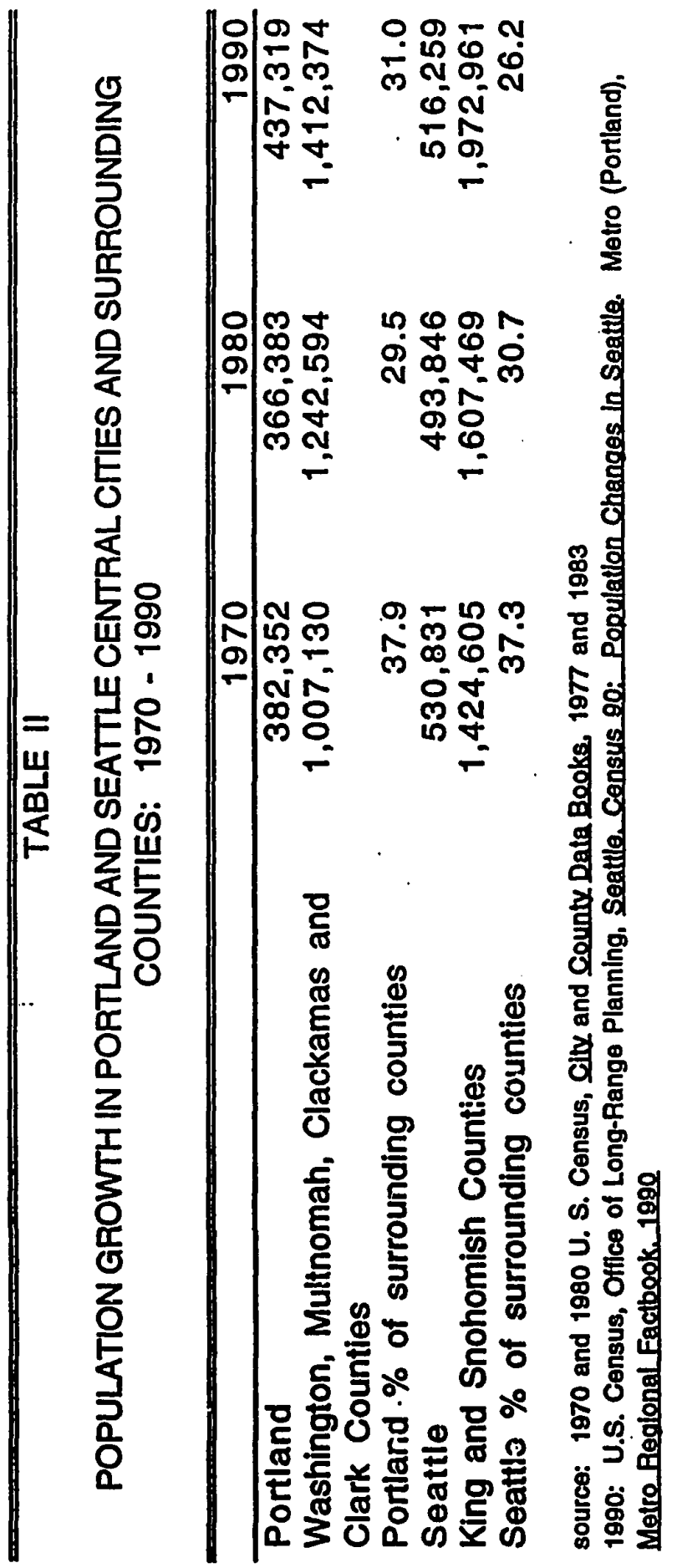


ㅇำ

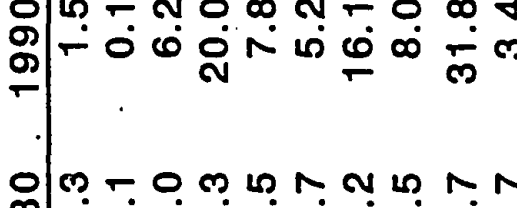

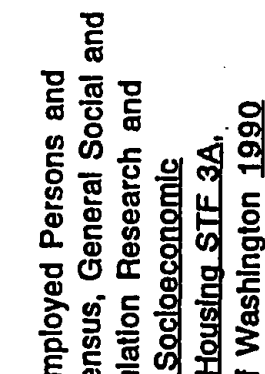

엉흐

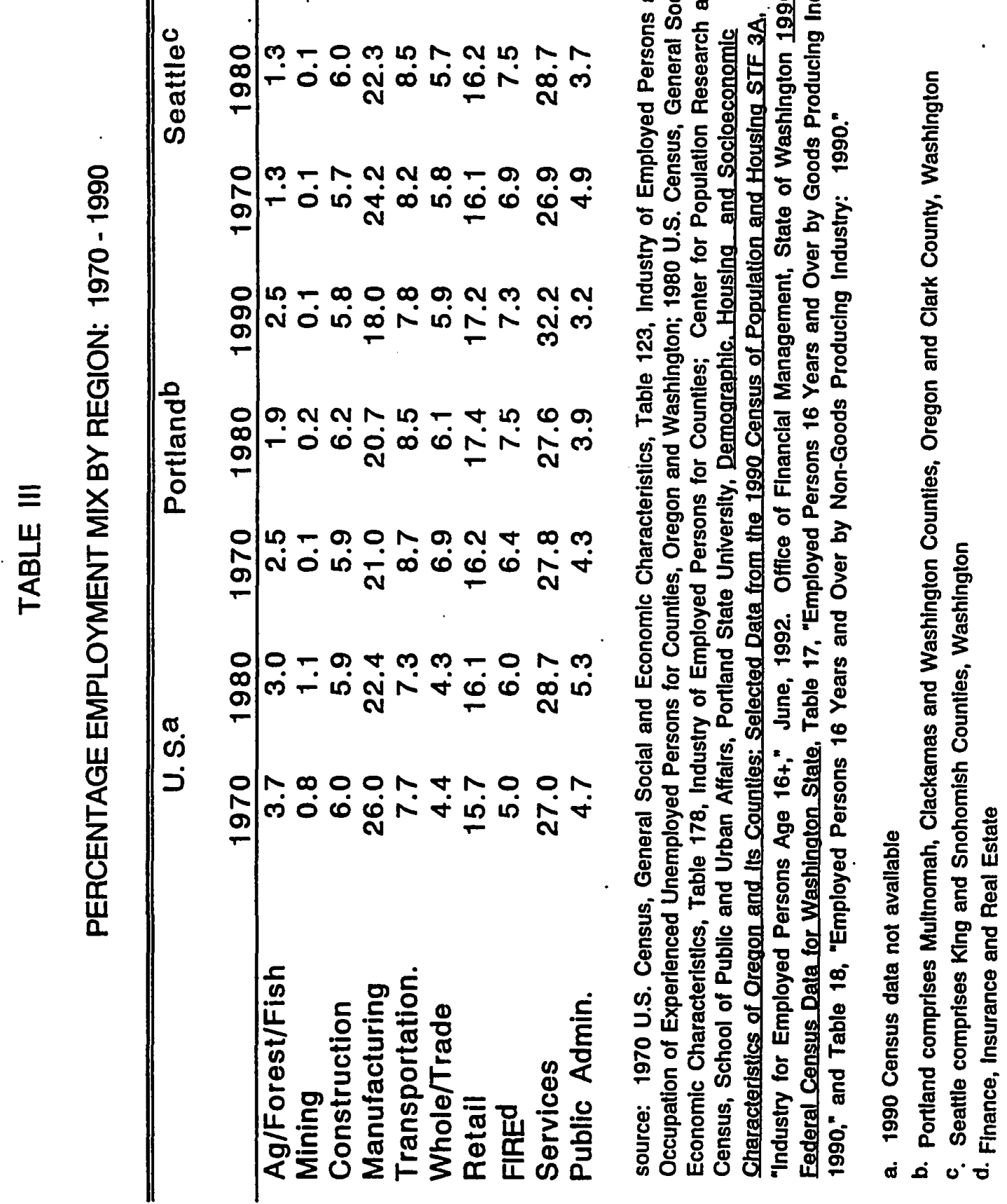


States for 1970 and 1980 and both regions for 1970, 1980 and 1990. These figures are given for the same geographic area as used for the previous population figures. Despite national trends in which manufacturing declined from 26.0 percent to 22.4 percent of employment totals, there was little shift in the regional mix. Both Portland and Seattle enjoy higher rates of employment in transportation and wholesale trade than the U.S., as would be expected for two major ports. In 1980, transportation employment accounted for 8.5 percent of total employment in both cities, 1.2 percent higher than the U.S. figure. Wholesale trade totaled 6.1 percent and 5.7 percent respectively, or between 1.8 percent and 1.4 percent higher than the U.S. Services accounted for more than one quarter of employment, followed by manufacturing, between one fifth and one quarter of employment and retail trade, which strengthened in the Portland region over the decade. Trends were similar in the 1980 s as service employment increased in each region at the expense of manufacturing and transportation employment. Likewise, the downtowns of each city had similar percentages of predominant services. 5 In both downtowns, service employment was the dominant category (Table IV). Portland's core planning area contains industrial districts such as the Northwest Triangle, Lower Albina, Central Eastside and Macadam industrial areas.

Suburbanization and the decentralization of economic activity affected retail and office functions in both cores. In Portland, downtown's share of retail sales fell from 17 percent in 1958 to 6 


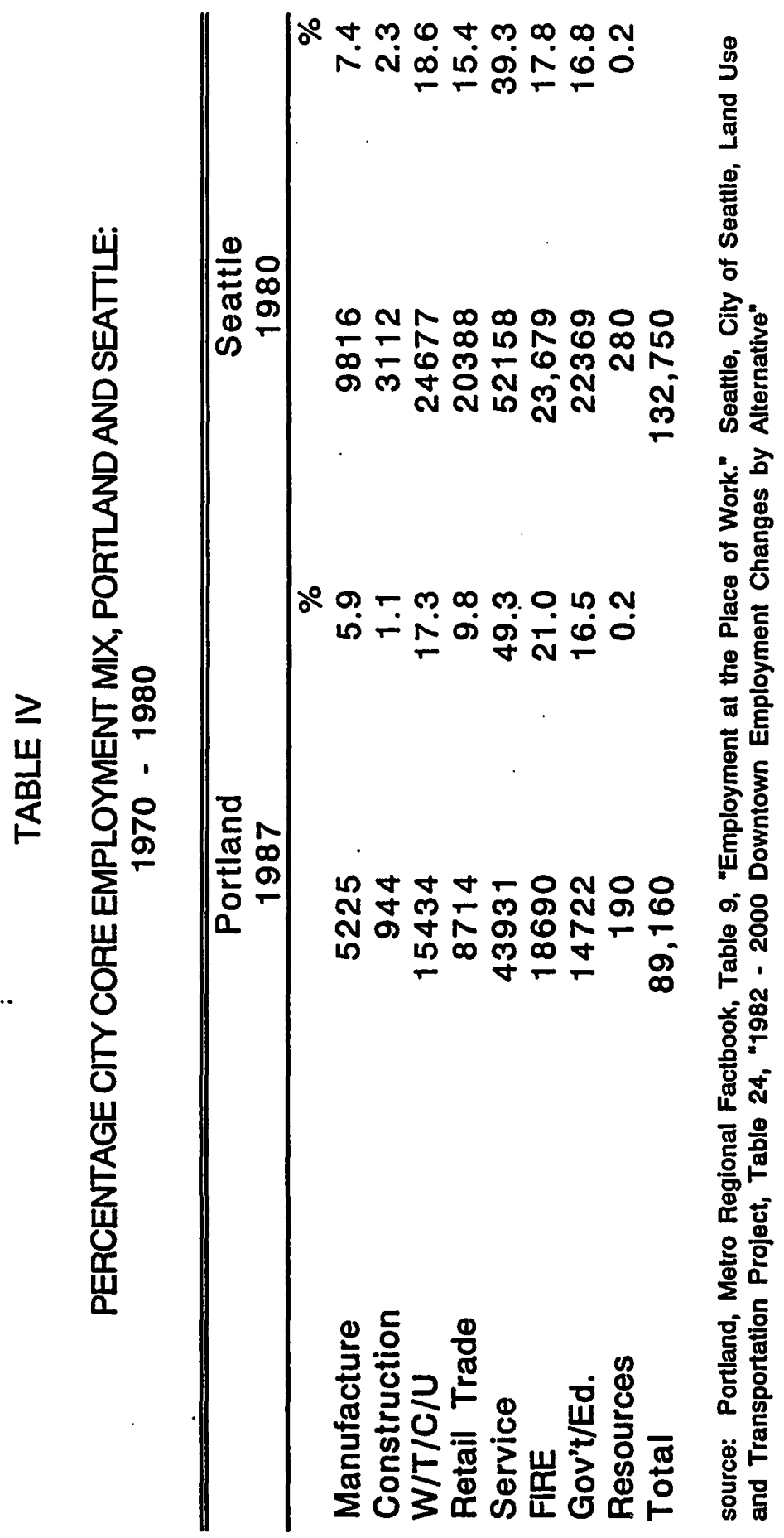


percent in 1972 to 4 percent in both 1977 and 1982.6 Although the market had stabilized, the downtown Morrison Street Project was envisioned to stop further erosion and cement the new strategy of upscale merchandising. In Seattle, downtown retail sales fell from 31 percent in 1954 to 18 percent in 1967 to 3.15 percent in 1982.7 These were absolute declines in Seattle, from $\$ 1.2$ billion to $\$ 975$ million in 1982 dollars. The Seattle Westlake Mall was envisioned to maintain the allure of downtown shopping by complementing the big downtown retailers with a specialty retail mall which would provide the popular festival marketing concept of the 1980's.

As both downtowns lost general merchandise dominance, retailers emphasized upscale, high quality, expensive and specialized goods. Despite continuing efforts to draw regional shoppers downtown through free parking programs, the majority of customers were downtown workers, tourists, business travelers and conventioneers. Unlike many U.S. downtowns, the retail cores remained vital. But they were threatened with the loss of their relative market share. The perception of status decline was linked to a sense that downtown might no longer function at the apex of the regional hierarchy.

Headquarters offices and specialized services have remained attracted to downtown areas because of the concentration of economic activities and high levels of services. But growth was greatest in the suburbs. In the 1980's both Portland's and Seattle's share of the regional market for prime office space declined. Competing office corridors along US 26 (Sunset Corridor) and Lake 
Oswego in metro Portland and Bellevue and Redmond in metro Seattle could now offer Class A office space. The downtowns captured only about half of the new construction in each region during this period.

Expansion of office space in Seattle $(900,000$ sq. ft. annual average in the 1970's), outdistanced Portland (200,000 sq. ft. average increase). In 1985 , Seattle contained $17,560,079$ sq. ft. of prime office space contrasted to Portland which had 12,468,561 sq. ft. In Portland, only half the CBD growth was projected to take place on the west side of the Willamette. CBD westside growth would be matched by the eastside Lloyd District, the downtown's auto-oriented twin. 8

Thus, by the 1980s, each city was a less significant part of a dynamic, expanding metropolitan area. Both downtowns were thought to require planning to respond to that less significant role. The retail cores searched for a future in dispersed economic geography.

\section{POLITICS}

Portland and Seattle both transformed from conservative to activist governments after World War II. City Hall and the downtown business community first faced the challenge of "Young Turk" business interests, and then social and environmental activists. 
Postwar Reform Politics in Portland

In 1948, Dorothy Lee beat long-time politician Earl Riley on police corruption charges. Riley had retained the support of big Portland businessmen including retailers Fred Meyer and Aaron Frank . of Meier and Frank.9 Lee created a Committee on Municipal Reorganization with the intention of modernizing public administration. The Committee suggested a city-manager form of local government. The effort was defeated 3-2 at City Council. A subsequent effort, led by a citizens committee, fell short of the necessary initiative signatures required. Lee was defeated in the next election without creating lasting political alternatives. With the election of Mayor Fred Peterson and continuance of William Bowes' 30 year reign as Commissioner of Public Finance, the city lapsed back into timid, conservative government.

\section{Reform Politics in Seattle}

Arthur Langlie was put forth by the Order of Cincinnatus to clean up Seattle. The Order of Cincinnatus was formed in response to the chaotic, radical politics of Seattle in the 1930s Depression. The Order was composed of downtown business interests, the Young Republicans and the Protestant Greater Seattle Council of Churches. ${ }^{10}$ The Order of Cincinnatus stressed honest government, reduced taxes and modest government expenditures. The Order of Cincinnatus disappeared from public view after effecting a political shift from radical to conservative. Under Langlie, government remained cautious, with a weak mayor and a council interested in 
balancing a budget. City voters turned down eight of eleven bond issues proposed by local government before World War II.11

Seattle was a businessman's city in the thirty years following Langlie's election. Private interest groups and citizen committees took the leadership role in Seattle. In the late 1950s, Delbert Miller, a professor at the University of Washington, identified a consistent inner ring of influentials in Seattle. Businessmen held eight of the top twelve positions in the innermost circle. The mayor ranked eleventh.12 This grouping was well known as the "Big Ten."

As Banfield described it,

If you want to get anything done in Seattle," says Ross Cunningham, political editor of the Times, "you get about six members of the Big Ten together and tell them it's a good project. If you convince them, you're in." The Big Ten is an informal group of downtown financiers, real estate men, and industrialists. Its representatives meet every week with Chamber of Commerce and press, radio, and television people in a 'Monday Luncheon Club' to discuss city affairs. No public officials are present, but it is said that big decisions affecting the city government are sometimes made.

The Chairman of the Board of Boeing was a member of the Big Ten, but he seldom participated in downtown development politics. Nor did Teamster President Dave Beck. ${ }^{13}$ Political historian Mark Sidran writes that the caretaker government "left downtown businessmen in a position of greater influence than might otherwise have been the case."14 The private Municipal League played the most public leadership role in the community. The League had fulltime staff and an extensive committee structure and in the mold of the Order of Cincinnatus, "played the government watchdog role." 
Its membership included "representatives of all the community's strongest interest groups and prestigious individuals."15

\section{Continuing Political Evolution in Portland}

A steady political evolution during the Terry Schrunk years helped to create a public-private partnership and diffused much potential conflict. In 1957, Terry Schrunk was elected Mayor of Portland as a moderate progressive. Shrunk's election followed four years of stagnation under Fred Peterson. Peterson's term (19531957) was marked by an eastside-westside conflict over the location of Memorial Coliseum. Citizens had required by initiative a location east of the Willamette River which revealed the split between the westside business interests and the voters who mostly lived on the eastside.

Peterson had also been involved with a failed attempt at urban renewal through the Housing Authority. The Authority had been unable to implement urban renewal in Northwest Portland and had left the city with nothing but public housing projects to balance the new opportunities in the suburbs. Schrunk revitalized urban renewal and fused private and public interests through the creation of the Portland Development Commission (PDC). The creation of PDC and approval of the South Auditorium project by a narrow vote in May, 1958 created an agency which would eventually learn from mistakes and become a powerful implementation tool of the Portland planning process. Despite support from the Chamber of Commerce, Labor Council, the progressive City Club, the conservative Oregon Voter 
and both dailies, it was still necessary to alleviate concerns that the Development Commission would be granted too much autonomy. A.V. Fonder distributed a review of legal constraints which would prevent PDC from gaining too much power. (This was well before PDC acquired an independent financial base in tax increment revenue.) Businessmen as well as voters distrusted City Hall. The virtue of the new agency lay in severing ties with the Peterson era and creating an agency that could get things moving on the west side. It also separated redevelopment from the social agenda of public housing.

Ira C. Keller, a prominent businessman became chair; other members included attorney A.V. Fonder, Roy C. Hill of the painter's union, Vincent Raschio of Portland Homebuilders, Jack R. Caufield, former U.S. Marshall. These members represented the mix of business, professional and union organizations expecting to benefit from urban renewal.

"Schrunk staked his political career on the success of urban renewal. He recruited PDC board members from the city's business establishment, gave them freedom of action, and expected tangible results."16 The action orientation of PDC was further enhanced by the first Commission chair, Ira Keller, who insisted upon unanimity and PDC Executive Director, John Kenward, who put together a remarkably talented team. Not only was a semi-autonomous agency freed of "politics," but later the agency acquired an independent financial base. Tax increment financing (TIF) allowed the city to use the increment in additional property tax revenue beyond the base 
year to fund future projects. Tax Increment Financing tied projects to an economic feasibility analysis, since project revenue had to pay off urban renewal bonds. This requirement disadvantaged housing projects which were difficult to pencil out.

Finally, Kenward and Keller emphasized urban design, not only as an aesthetic, but in a larger functional sense. The South Auditorium project was designed to create a stabilizing, enhancing influence on downtown and to complement the retail core, not to compete.

City Council approved the South Auditorium project on June 18, 1958 over the objections of 85 residents, bitter that the city was displacing them. Portland financed that displacement through a New York syndicate. Despite sympathetic portrayals by the Oregon Journal and sporadic resistance, the 68 business firms and 470 families had no support from Council. The community came to associate urban renewal with government power and insensitivity. The newspaper headlines read "Residents, merchants, sad, bitter as renewal area move-out nears."17

\section{Mid-Sixties Challenges in Seattle}

The mid-sixties were years of tremendous growth, physical expansion and challenges to city governiment in Seattle. The Municipal League, League of Women Voters, and establishment groups such as the "Citizens Committee for Strengthening Seattle Government" sought institutional reforms to modernize local government. However, the Council remained conservative at a time 
when even the downtown business community, reorganized as the Central Association, began to push for a more activist government. A new organization arose to articulate the values of Kennedy's New Frontier. In 1967, a group of law school students and recent law graduates of Washington, Harvard and NYU met, both Young Republicans and Young Democrats. The new group met under the auspices of the Governmental Affairs Director of the Seattle Junior Chamber of Commerce. The group took up the challenge of the downtown establishment weekly, the Argus:

The time is ripe for a young non-partisan group to select and put up for election a full slate of candidates for the Council at the next municipal election ... (T)he voters of Seattle would welcome with open arms an infusion of new blood in the Council. But they must be good candidates, backed by substantial and responsible people. ${ }^{18}$

The group's name and acronym laid out its program - CHECC Choose an Effective City Council." A measure of the politics of the time was that this new grouping was anxious to avoid arousing the opposition of the downtown business leadership. The city press, well-attached to the city's business establishment, supported CHECC in return. CHECC's two candidates both defeated incumbents. CHECC's formation was an important milestone in Seattle politics. A highly political, city-wide grouping sought to have impact on nonpartisan elections like the old Order of Cincinnatus, but through the adoption of modern techniques - position papers and media press conferences. CHECC created a model for future urban activists organized around issues. Now that urban activists were on the scene, 
downtown development would be increasingly perceived as a citywide issue. The most significant activists would be grouped around historic preservation and housing/displacement issues.

At the same time that CHECC was creating the potential for wider citizen politics, businessmen were embarking on the greatest and last privately initiated venture, Forward Thrust. In November, 1965 Attorney James Ellis called for $\$ 819$ million dollars of road, sewer, parks and other capital improvements. Agreements among Boeing, Western International Hotels, Pacific Northwest Bell and Seattle - First National Bank (the "Big Ten") had all come before the public announcement. Ellis announced this message to the Seattle Rotary Club in November, 1965, and called for a county-wide community effort to combat pollution and congestion in the face of the region's suburbanization. Shortly thereafter, a "Committee of $200^{\prime}$ representing various interests in the county was organized. The size of the committee as well as the varied package of projects was a reflection of the fragmentation of community interests:

In a political system in which city government is either unwilling or, due to the dispersion of authority, unable to act, interest groups and citizen committees assume particular importance in promoting action and leadership. ${ }^{19}$

The converse of this observation is that city hall would also be vulnerable in controlling conflict. The city would be faced with dissident groups who could impede or stop in-city projects such as Pioneer Square, Pike Place Market and Westlake Mall urban renewal. 
Forward Thrust parks improvement bond issues passed in February, 1968. One of the bond measures provided for parks throughout the city, including downtown.

Neighborhood-oriented activists were elected to Council. From 1971 on, neighborhood organizations were permitted to decide how to spend the Forward Thrust moneys for neighborhood improvements. Neighborhoods were empowered, spending money and gaining confidence. Funds were earmarked for neighborhood and downtown parks.

\section{Downtown Activism in Portland}

Despite urban renewal successes south of downtown, downtown Portland continued to decline in the Sixties. One of the nation's largest regional malls, Lloyd Center, opened in 1959 on an eastside site over a mile from downtown. The location was convenient to the eastside freeway and offered thousands of parking spaces. At the same time, the erection of Memorial Coliseum on the east side indicated a shift in the balance of power harmful to westside interests. Businessmen formed Downtown Portland, Inc. and tried several parking schemes to lure customers back. Bill Roberts, prominent downtown retailer, was elected chair of Downtown Portland, Inc. in 1960. Another business group formed in 1963, Downtown Associates. Although this was also short-lived, the group initiated one of the first downtown development studies, a decade before the Downtown Plan. Nothing appears to have come of this study. Downtown interests were unable to get things moving. 20 
One more business group was organized in the fall of 1968 . The Portland Improvement Corporation (PIC) was organized and designated a Downtown Committee to initiate a parking. study. PIC president was Paul Murphy, who represented the Ladd Estates, a long-established land development firm. Board members included Ira Keller; Glen Jackson, chair of the Oregon Department of Transportation; Bill Roberts; Julian Cheatham, the vice-president at Georgia-Pacific; Frank Warner of PGE; and banking officials. Declining retail sales and increasing congestion were hurting downtown. The attempt to duplicate the suburbs brought an increasing loss of character. In 1969, Bill DeWeese, President of the Chamber of Commerce, called for a committee of 50 to suggest an agenda for private and public action over the next ten years. These 50 citizens were to be appointed by the Chamber, the mayor, the Multnomah County Commission chair, the chair of the Portland Development Commission and the president of Lewis and Clark College.

In 1970, thirteen top businessmen organized the Downtown Committee. These businessmen included Edwin W. Steidle, president of Portland's largest department store, Meier and Frank; William E. Roberts, former president of the other large department store, Lipman and Wolfe; Glenn Jackson, head of the Oregon Highway Commission and one of the most influential men in the state; Ira Keller of the PDC; and the heads of major banks and realty firms. The Committee hired a firm of economists and planners. Robert $S$. Baldwin, the Multnomah County planner, was loaned to head the 
Downtown Plan effort. The committee moved aggressively but the public, particularly the architects, objected to the lack of citizen participation. Portland City Commissioner Lloyd Anderson was sympathetic to citizen concerns. A compromise was effected whereby a Citizens' Advisory Committee (CAC) brought reputable citizens to the effort. The chair of the committee, Dean Gisvold, a supporter of Schrunk's chief rival, liberal Neil Goldschmidt, chaired a series of negotiation sessions in which the Plan was hammered out. 21

The Citizens' Advisory Committee (CAC) supplied goals and objectives which still guide downtown redevelopment. The Committee formed task forces on Housing and Downtown Neighborhoods, Commerce, Waterfront, Portland State University/Park Blocks and Transportation. Each task force digested public comments from Town Hall meetings and planning reports and forwarded a proposal to the CAC. In about 18 months the Planning Commission and City Council ratified the "Planning Guidelines, Portland Downtown Plan" (December 28, 1972). The Downtown committee, chaired by Paul F. Murphy, and the Citizens' Advisory Committee, chaired by Dean Gisvold represented a balance of interests. The business representatives lent credibility; the CAC supplied public approval. These two groups hammered out compromises in frequent working sessions. Thus, both business and "quality of life" issues were addressed.

The plan process transformed a parking plan into the Downtown Plan. The plan sought the revitalization of downtown as 
an office and retail center while revitalizing housing, recreating a waterfront and taming the automobile. The Downtown Plan revitalized downtown by providing the framework for massive public investment in transit, parks and commercial development (Figure 6 illustrates the Downtown Plan concept.) Access and economic vitality were hitched to public transportation. The Plan failed to address housing and social problems north of Burnside Street, bring the middle-class back downtown or create a permanent solution to the parking/air quality dilemma.22 However, these issues were secondary to revitalizing the downtown core. The Downtown Plan managed to be both visionary and pro-growth.

The Downtown Plan combined a desire to reinforce the dominant position of downtown Portland with quality of life issues such as urban design, historic preservation and mixed land use. For example, the commerce goal read: "Enhance Downtown's role as the leading center for retail goods and consumer services. Provide an atmosphere conducive to investment."23 The most significant result of the Downtown Plan was the commitment to mass transit as a principle means of access to Downtown. As this entailed the conversion of SW Fifth and Sixth Avenues to a bus mall, there was significant opposition on the part of retailers, especially Meier \& Frank. The department store was located between SW Fifth and Sixth and had been previously embroiled in an unsuccessful attempt to build a customer parking structure in the heart of downtown. Bill Roberts, the first chair of the Tri-Met board got the mall built. Despite real controversy, eventual economic success won over the 


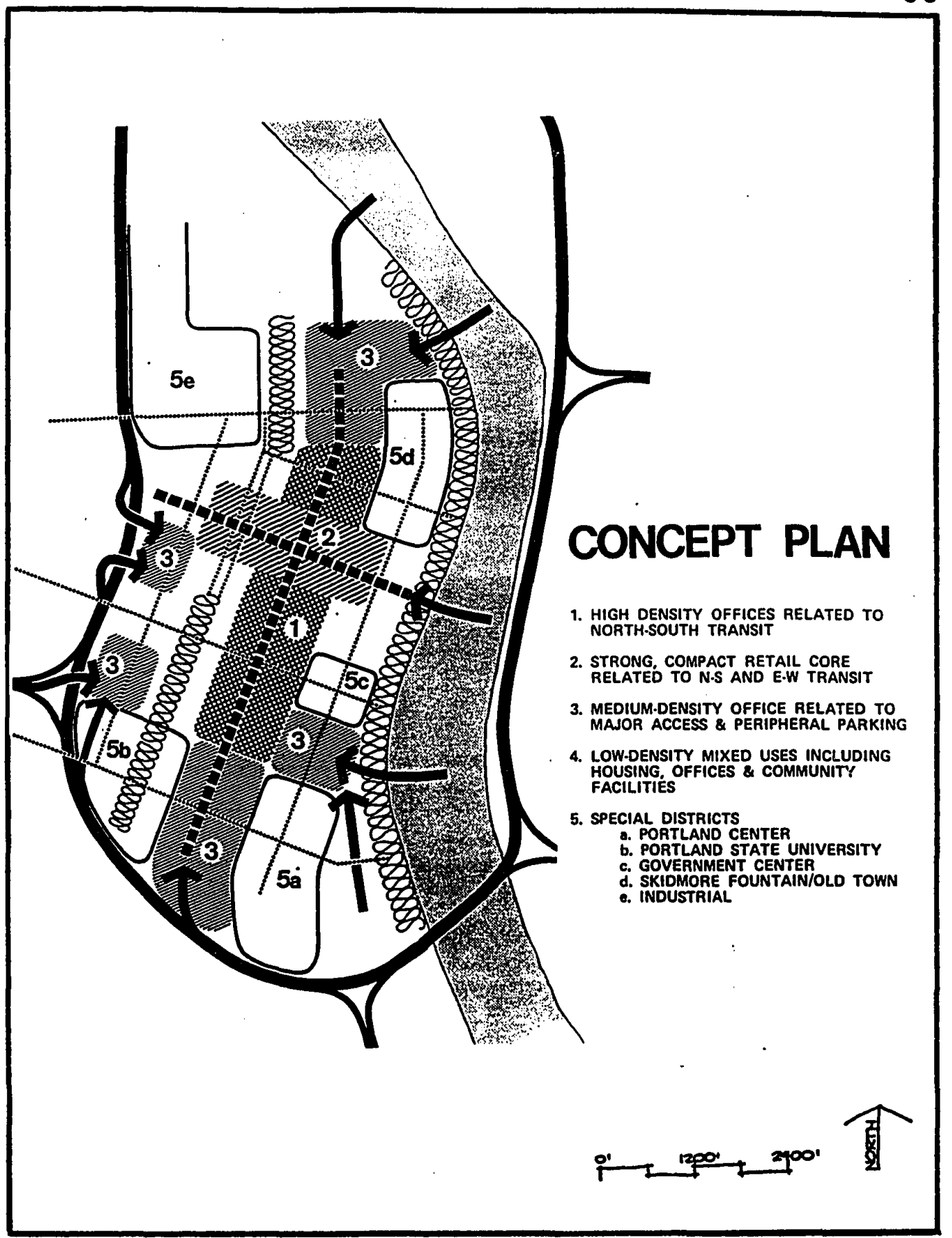

Figure 6. Downtown Plan Concept. From City of Portland, Planning Guidelines: Portland Downtown Plan (1972). 
Portland business community. As the official history of the plan states:

The preparation and implementation of the Downtown Plan and Program was an outstanding cooperative endeavor involving Portland's business community, intensive citizen participation, planners and urban designers, with the pivotal support of local, State and Federal governmental officials and agencies. This endeavor is exemplary because the process of Plan/Program preparation and implementation has involved the cooperative participation of the business community, the citizens of Portland and every level of government. 24

One practical result of this mythology is that neither neighborhood organization nor citizen activist can escape the community's expectation for "public-private" participation. The Morrison/Pioneer Place project, the Central City plan and even those parties disputing social service issues were constrained to work within the bounds of consensus and negotiation. One of the few groups willing to act outside these bounds was the Burnside Community Council. BCC was an activist organization north of Burnside in skid road, the Downtown Plan's only failure.

A significant effect of the Downtown Plan was to trigger private investment in the core. Plan implementation also redirected the city's Development Commission toward this end. As a major element of the Downtown Plan, the City created a massive urban renewal project along the waterfront in April, 1974. Governor Tom McCall's riverfront project area was expanded to incorporate a faded downtown area within four blocks of the waterfront. Adoption of 
the waterfront program guidelines was handled by Bob Baldwin concurrently with his work on the Downtown Plan.

PDC survived two midcourse corrections to emerge as the linchpin to the implementation of the Downtown Plan. In 1971, the City Club went on record favoring the abolition of PDC and urging merger with the Housing Authority of Portland or at least the creation of a superagency which would combine Planning, PDC and the Building Bureau.25 PDC was faulted for its lack of citizen participation and comprehensive planning. Ira Keller ran the Commission as before. PDC policy-making was considered backroom politics. Neil Goldschmidt ran for Mayor, promising to abolish PDC. Goldschmidt soon learned that he needed the agency to accomplish his downtown agenda. PDC had the tools and the expertise; no one else could build Waterfront Park. 26

Goldschmidt created the Office of Policy and Development within his portfolio to coordinate development. OPD also received federal money. The newly created OPD had responsibility for implementing Goldschmidt's vision and coordinating PDC with Planning and other development agencies. OPD created a long term agenda for PDC to implement the new Downtown Plan. PDC began to work well with Bureau of Planning staff, notably Rod O'Hiser who met weekly with PDC. George Sheldon, chair of the Planning Commission in 1973 also helped to coordinate the new downtown development policy.

In 1977, PDC misstepped again when it offered public park land for tennis courts for Marriott Corporation's proposed hotel guests. 
The Office of Planning and Development was called in to investigate but suggested budgetary and reporting reforms rather than abolition.27 The Commission withdrew from the Marriott deal and one of the few citizen suits was withdrawn.28 (Within the study period, the Cadillac-Fairview deal would again cause community scrutiny of PDC project management.)

Neighborhood Activism in Seattle

On July 10, 1972, the City Council adopted Resolution 23684 establishing the Seattle 2000 Commission. Mayor Wes Uhlman supported the commission. For six months, hundreds of citizens participated in numerous task forces, discussion groups and hearings to produce a 330 page policy document. Community, liveability, preservation and protection of residential neighborhoods became the priority quality of life issues. Yet the Goals also promoted the primacy of Seattle throughout the region. The city committed to an elaborate process of setting population targets and rewriting the Comprehensive Plan in single family, multi-family and commercial districts in order to implement the Goals for Seattle 2000. Throughout the 1970s, increasing conflicts over permissive zoning densities and the impact of overly large apartment projects began souring relations between the neighborhoods and City Hall. Zoning battles nurtured citizen involvement in Queen Anne Hill and Capitol Hill. Neighborhood activists did not yet connect between downtown growth and displacement/gentrification in surrounding neighborhoods. 
Seattle was concerned to keep a vibrant downtown, the center of the region, "the pre-eminent center for business, governmental and cultural activities in the region."29 Downtown, livability was cast as a set of urban design principles:

The planning and development of the downtown should bring about a unified, well-integrated whole, while maintaining and enhancing the identity of areas of special character or emphasis. The Seattle downtown is and should remain the headquarters of the region, where activities of a citywide and regional character, and activities requiring dense concentrations of people, or other kinds of concentration, should tend to be grouped. Major retail trade, principal financial institutions, headquarters of enterprises both commercial and notfor-profit, the executive offices of government, all benefit from downtown location and all contribute to one's sense of downtown as the center of significant thought and action. Such a center should contain the major cultural, entertainment, and urban recreational institutions. 30

This goal would become the foundation for an aggressive downtown growth strategy in the subsequent decade. But vibrancy and special character would translate differently for different actors. The Sierra Club, Allied Arts, and the downtown business community, then represented by Downtown Seattle Development Association, would grab different facets of the internally contradictory Goals for Seattle 2000.

Thus, the 1970's saw increasing complexity and potential for conflict over quality-of-life issues endemic to zoning, housing affordability and public participation.

In 1974, Uhiman proposed that an Office of Policy Planning be 
created. The Goals for Seattle 2000 had called for more centralized planning. OPP was created by Ordinance 104067 "to coordinate currently fragmented City policy making and Planning." OPP was responsible for human resources and criminal justice planning along with housing, transportation and land use. OPP also took on shortrange problem solving for the mayor. OPP elected to begin a series of land use policies rather than draft a conventional comprehensive plan. OPP also began to range farther afield than physical planning. OPP expanded the number of its activities - amenities, urban design, and social welfare.

This amounted to premature meddling with community values and interfered with the efforts of the agency to become accepted by the public. Liberal Seattleites were quite satisfied with the OPP-sponsored studies, but business and other established interests that favored development did not believe such work contributed to their goals. 31

OPP barely survived the budget process in 1978 and was reorganized in 1979. OPP became OPE, the Office of Policy and Evaluation. Planners were spun off into line agencies as part of a general decentralization. Two years later, the agency lost all functions except commercial district and downtown land use planning. Relabeled the Land Use and Transportation Project, the office was retained within the Mayor's Executive Department. The decentralization of planning and the legacy of OPP made it difficult to handle increasing neighborhood conflict resulting from the increases in density allowed by the zoning code.

During the first half of the 1980's, little new construction was done because of a weakened economy 
and delays in drafting of the new code language from the policy plans. As a result, the projected densities of the code were still unrealized. When the economy recovered, however, building starts took off. Neighborhood residents were suddenly dealing with the actual impacts of the new functional plans and land-use code, and many didn't like it. Those neighborhoods facing extensive development began pressuring City Hall for relief. 32

Mayor Royer had run a "think small" campaign in his successful 1977 campaign for Mayor. He called for a park at Westlake; a reduction in the 1-90 freeway project connecting the eastern suburbs to downtown Seattle; more city resources for smallbusiness development and low-income housing and roll-back of fast growth residential zoning enacted during the UhIman administration. Mayor Royer's constituency of "activists and camp followers in Seattle's vigorous feminist, minority, lesbian/gay and senior communities" 33 expected dramatic changes in the new administration. Royer had directly challenged Paul Schell, the former director of the city's Department of Community Development and the candidate of the downtown business community. However, Royer's commitment to a re-evaluation of neighborhood densities did not extend to a parallel stance against downtown growth. (See Chapter IV, VI and VIII for Royer's evolving position on the downtown Land Use and Transportation Plan, Westlake, and housing displacement.)

\section{Comparison}

The adoption of the Downtown Plan in Portland and the Goals for Seattle 2000 at the same time in the early 1970's indicates a 
common interest in reinforcing the dominant position of downtown Portland and Seattle and in grafting on quality of life issues such as good urban design, historic preservation and mixed land use. Both cities benefited from strong mayors, Goldschmidt and UhIman, who centralized planning and began implementation of these policies. Portland's downtown plan cemented relationships between the planners and the business community. PDC began a series of projects which leveraged private investment with public moneys using tax increment financing. Public disenchantment with PDC methods did not include questioning of the city's basic "public/private" partnership. The city had firm direction in its efforts to promote downtown growth, including investment in retailing. 34

Seattle adopted the Goals for Seattle in 1973, but waited a decade to begin downtown planning. In the meantime, increased zoning densities and growth led to increased conflict.

Decentralization of planning precluded an effective bureaucratic response. Mayor Royer campaigned against City Hall. When the city decentralized the planning function during the Royer administration, the city lost its connection to a "comprehensive, Jong-range vision."

Finally, there is concern among the public that the exercise of planning becomes an end in itself, rather than a catalyst for action. Without the link between planning and implementation, the work produced in planning is often shelved. While citizens have identified the need for City-wide and neighborhood planning and want public outreach to be a meaningful part of the process, they are looking for assurances that this work set the stage for resource allocation. In short, planning should go beyond 
identifying outcomes and set out phases of implementation. 35

When the city embarked upon a Land Use and Transportation Plan for downtown in the early 1980's, an ad hoc bureaucratic organization within the executive department was created for that sole purpose. The lack of centralized planning and/or planner credibility made it extremely difficult to diffuse controversy through negotiation. Seattle assigned a purely advisory role to the Planning Commission. Unlike Portland, the Seattle Planning . Commission did not act as a filter to constrain political conflict before the Council. City government was not able to translate a new activist Seattle spirit into an institutional framework for blending private and public interests. 36

\section{SOCIOECONOMIC CONTEXT}

Portland and Seattle both grew slightly in population in the 1980s - Portland grew primarily through annexation and Seattle primarily through increasingly dense residential infill construction (See Table V). In neither city did annexation or gentrification create significantly different cities compared to each other or to the previous decade. In 1990 Seattle had a significantly greater Asian population than Portland, 11.8 percent vs. 5.3 percent but even Portland's percentage was twice as high as the U.S. (5.3 percent vs. 2.9 percent U.S.). Seattle had a larger black population at 10.1 percent of the population versus Portland's 7.7 percent. But Seattle's total gain was less than the national figure of 12.1 percent 


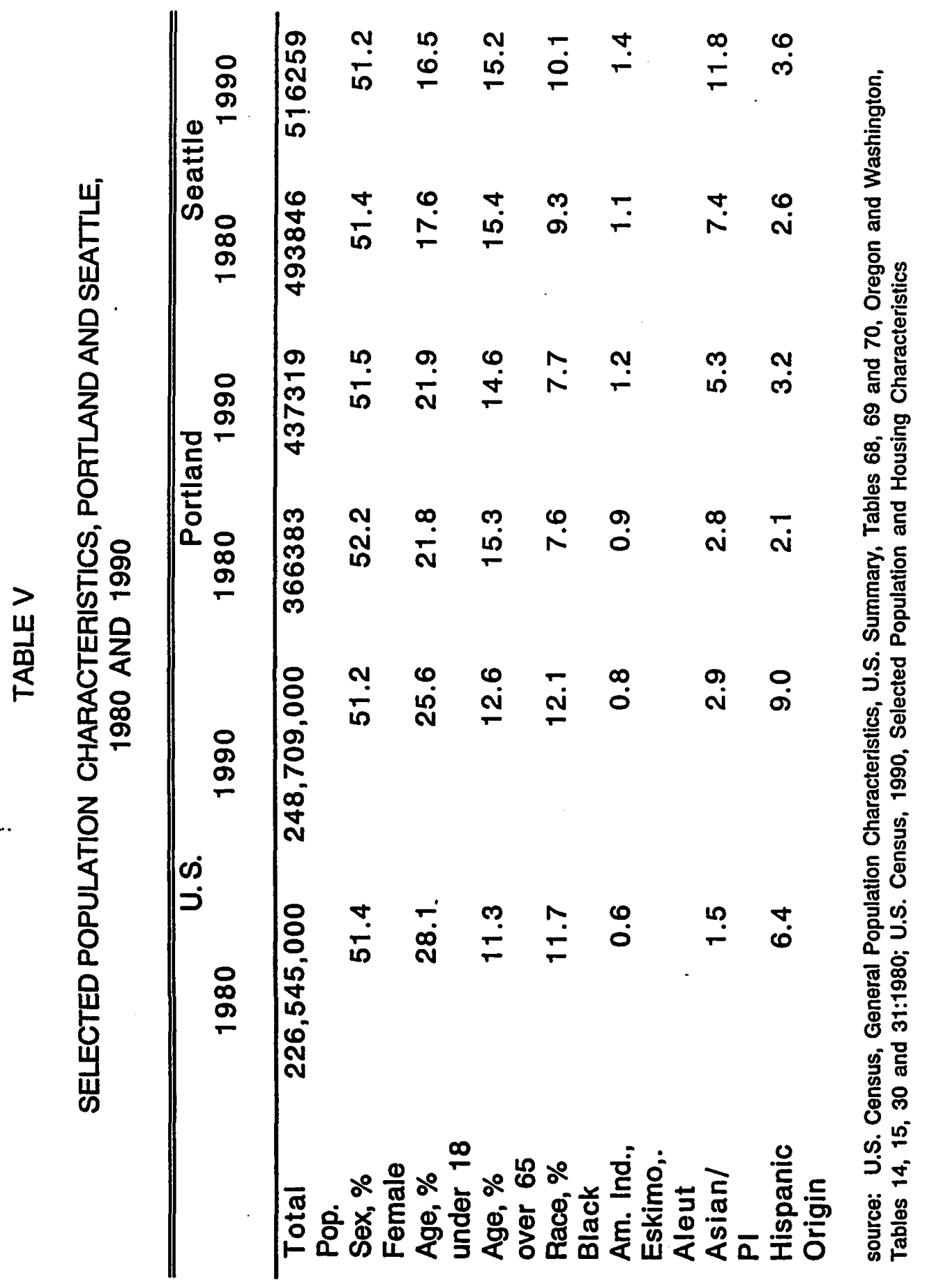


for all metropolitan areas. The two cities contained few Hispanics compared to the national percentage (3.2 percent and 3.6 percent compared to 9 percent). The two cities were homogeneous and alike compared to the national average. Portland and Seattle had diverged less than Seattle's more numerous office towers might suggest.

Both cities were evenly balanced between homeowner and renter. In 1990, 53 percent of 198,000 housing units were owner occupied in Portland. In Seattle, 48.9 percent were owner occupied. Seattle housing was becoming increasingly expensive. While the median owner occupied unit was worth $\$ 59,000$ in Portland, in Seattle the median value was $\$ 137,000$. In 1990 , median rent in Portland was $\$ 340$ in Portland, compared to $\$ 425$ in Seattle. Median income was not reported in 1990 census summary reports, but the per capita income in 1983 was $\$ 11,444$ in the Seattle Primary Metropolitan Statistical Area (PMSA) and $\$ 9,803$ in the Portland PMSA. 37 Seattle housing was perceived to be in an affordability crisis compared to Portland, but downtown, the circumstances were similar - housing was disappearing.

Downtown resident populations were crucial to hopes for keeping the downtown an 18- or 24-hour neighborhood. Table VI lists population, housing units and race. Population and housing units stabilized over the 1980's. Although minorities made up a growing percentage of downtown residents, Portland - from 15 percent to 20.5 percent in Portland and from 27.8 percent to 33.3 percent in Seattle - relatively low figures. Economic growth and/or building code enforcement often squeezes the amount 


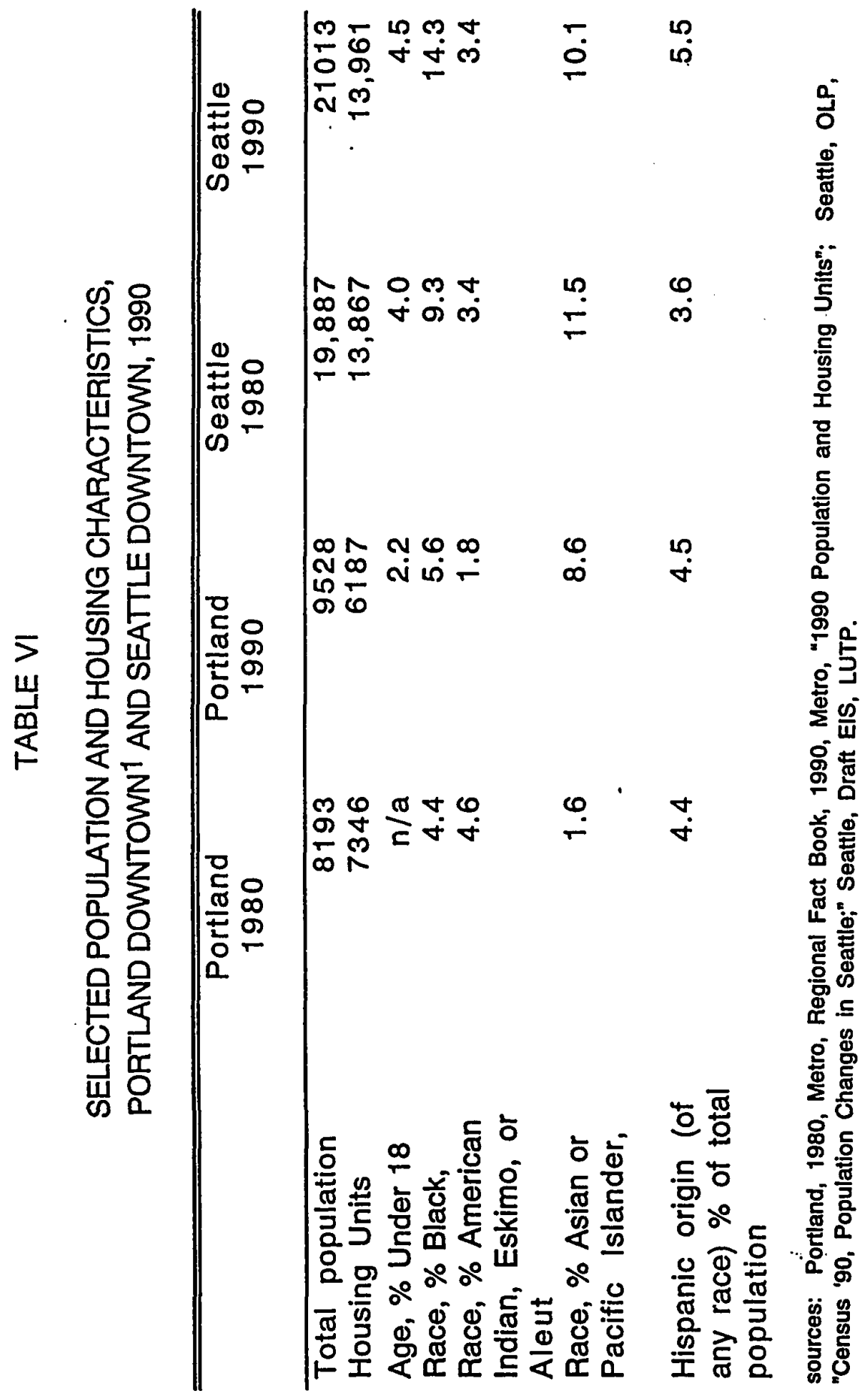


of downtown housing. In 1980, the Portland Central City plan area contained 10,092 housing units, 6.4 percent of the city's total housing. Most housing was low-income. Single Room Occupancy (SRO) housing units accounted for 16 percent of the housing stock. Since 1970, the downtown had lost 2,400 SRO units, or 59 percent of the previous total.

A similar loss was reported in Seattle. Approximately 15,622 units had been lost between 1960 and 1983.38 In 1982, the Seattle downtown contained 9,164 housing units, of which 7,311 were lowincome. The draft environmental impact report of the Seattle Land Use and Transportation project forecast an additional loss of 3,073 low income unsubsidized units, about half of the 7,311 low-income housing units of a total of 7637.39 The Seattle planning study also indicated that additional downtown workers would create a demand for 55,157 housing units of which only 2,768 would be created by the plan. 40

These trends were well-known to decision makers in both cities in the early 1980s: Although strong, the position of manufacturing was threatened by the recession and by a national economy which continued to shift from a manufacturing to a service, information and professional base. Most downtown residents were expected to be predominantly low-income and in need of social services. Downtown social service agencies were finding it difficult to disperse throughout the region. Both cities continued to grapple with housing and social service crises. Neither city had yet succeeded in bringing the middle-class back to the core. Both cities 
sought to reposition themselves in the regional market with new projects downtown.

\section{GEOGRAPHY AND GROUP INFLUENCE}

With growth and economic transformation has come a corresponding shift in core district functions. As the central business district grew, relocated and became distinguishable from the port, maritime terminals in each city relocated away from our study area. The central business districts moved less than a mile up and away from the threat of flooding, leaving the original townsite to become the workingmen's and then transients' quarter. Middleclass and wealthy residential districts moved to higher sites separated from the downtown. This has resulted in similar downtown districts and patterns of group influence.

\section{"Zones of Discard"}

In Portland, the Skidmore/Old Town and Yamhill historic districts remain from the original commercial district. The Skidmore/Old Town district retained its connection to the working waterfront but lost most commercial activity to the relocated business district. After World War II, the district became the Skid Road of Portland and residents became mostly social service agency clients. Development politics became increasingly centered on the "transient problem." Business associations were oriented toward small business owners, often sluggish until a threat appeared on the horizon. Portland's Old Town Merchants Association was replaced by 
the more shrill Union Station Business Association in the 1980s. Highway projects fragmented the Yamhill district. The area to the south of the Yamhill Historic District was destroyed by highways and by urban renewal. South of Market Street, an old ethnic district was torn down and replaced with the South Auditorium urban renewal district of offices and high rise residential towers (See Figure 7). Comparable areas in Seattle include the original townsite, along Yesler Way, as part of a low-income residential crescent which arcs from the International District (east of the Kingdome), to Pioneer Square, north through the First Avenue Corridor, to Pike Street Market and the Denny Regrade (See Figure 8).

As these older areas were often historic districts or provided minority or low-income housing, activists played a part in some public redevelopment decisions. Portland's Chinese Consolidated Benevolent Association in Old Town was paralleled by Seattle's International District Improvement Association. Historic boards in Portland's Skidmore/Old Town district were paralleled by historic groups in Seattle's Pioneer Square and Pike Place. Similar social service agencies existed in both Portland and Seattle.

\section{Newer Reinvestment Areas}

Portland's center moved gradually at the turn of the century from SW Front to SW Fifth at SW Morrison around the federal courthouse (now called Pioneer Courthouse). The Meier \& Frank department store was located in the new heart of downtown. Office structures were built nearby until the Depression. In the 1950s, 


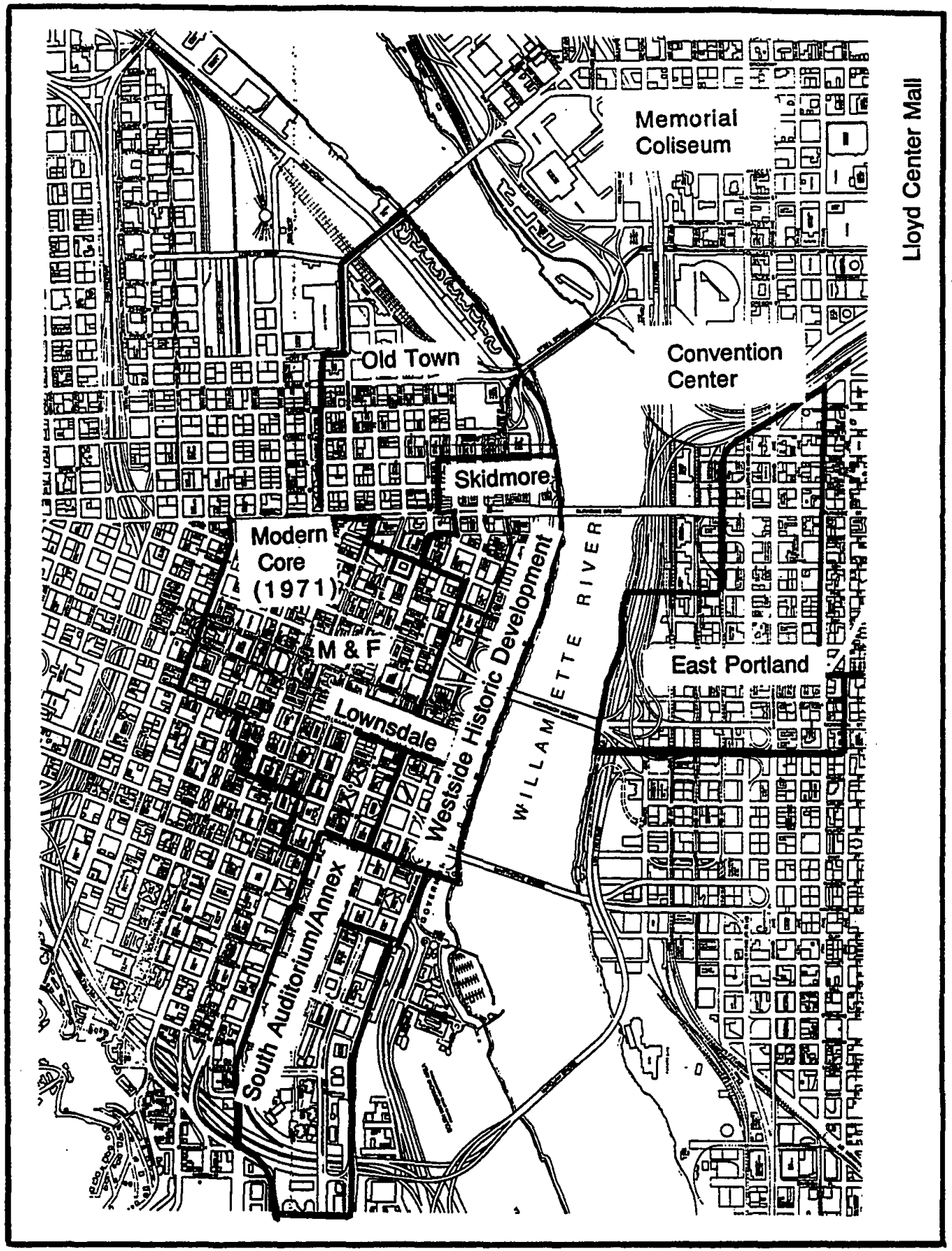

Figure 7. Portland Historic Development. 


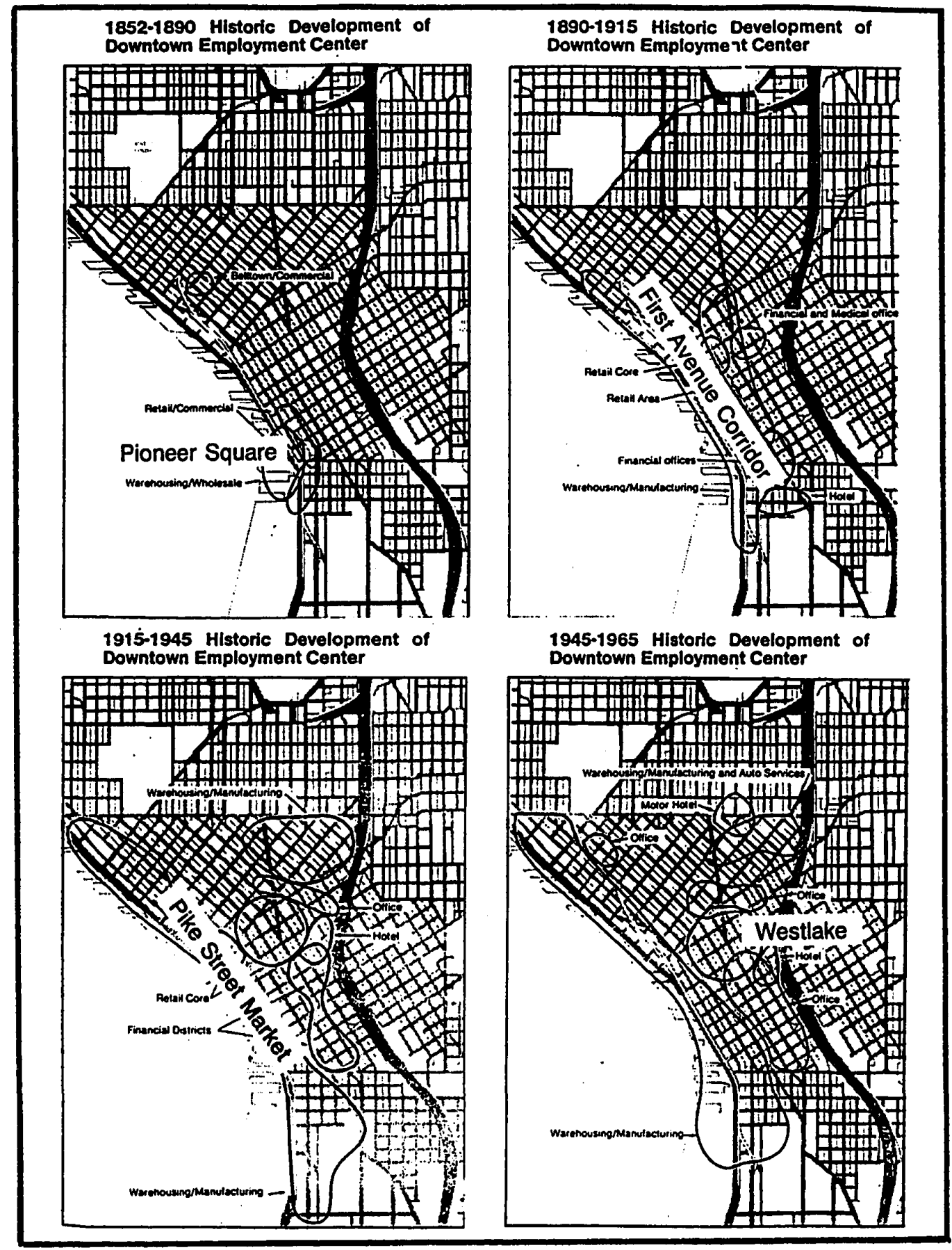

Figure 8. Seattle Historic Development. From City of Seattle, Land Use and Transportation Project (1981). 
Meier \& Frank demolished the city's premier hotel, the Portland Hotel, for a two-story structured parking lot. This was then replaced in the 1970 s with a city plaza/light rail hub, Pioneer Courthouse Square, to anchor the retail district. The city also proposed in the late 1970 s to locate an upscale retail mall to further anchor the retail district. The history of this project is discussed in Chapter IV. The building of the Transit Mall along SW Fifth and SW Sixth in 1977 and light rail along SW First to Yamhill and Morrison in 1985 promoted new office construction surrounding the retail core. The growth of the South Auditorium urban renewal district knitted disparate areas into a large westside office and retail core. The Lownsdale neighborhood was lost to new office construction. However, at the same time, the construction of the Lloyd Center Mall in 1960 created a retail and office competitor about a mile away on the east side of the Willamette. The Lloyd property interests were headquartered in Los Angeles and did not form a neighborhood association. By the study period, the Lloyd interests had sold the Lloyd Center Mall and several dozen eastside city blocks to the eastside electric utility, PP\&L.

The focus of Seattle moved from Pioneer Square to SW Fourth and SW Fifth Avenues in the vicinity of Westlake. Big retailers such as Bon Marche, Frederick and Nelson, and Nordstrom clustered in the retail core between SW Union Street and Olive Way (several blocks to the east of Pike Street Market, the city's farmer's market). Westlake Mall was intended to complement a downtown retail core lacking much public open space. The history of this project is . 
discussed in Chapter V. New offices were located to the south of the retail core. The area from Pioneer Square to Pike Street Market along the First Avenue Corridor provided investment opportunities for historic "adaptive re-use."

Downtown Portland was represented by business groups such as the Portland Improvement Committee, the Downtown Committee and eventually the permanently established Association for Portland Progress. Seattle formed the Central Association and then the Downtown Seattle Development Association. These business groupings evolved from informal groups meeting weekly to more organized fee-based business lobbyist organizations. These organizations were relatively uninterested in peripheral areas. Downtown residents also organized on a more piecemeal, informal basis. The Portland Downtown Community Association was a recognized association, but vacillated between activists and affluent residents throughout this period.

\section{Manufacturing and Wholesale Trade}

Manufacturing and wholesale trade areas are adjacent to both cores. Both Portland and Seattle have sluiced down hills and filled in lower ground for industry. Portland sluiced portions of the West Hills to fill in marshy ground along the river to the north of downtown. In Portland, the Northwest Triangle to the north of downtown on the west bank, the Macadam district to the south of downtown on the west bank, and the Albina and Central Eastside districts on the east bank were distinctively different districts 
from each other and from downtown. These distribution and industrial areas also contained lower income housing. Some Portland districts such as North Macadam were dominated by a few large, established enterprises. Others such as the Central Eastside Industrial Council were composed of many small businesses facing obsolescence.

Seattle industrial areas were located south of downtown along the Duwamish River. Former industrial areas along Eliott Bay north of downtown were filled. These areas have been considered out of the central planning area. Likewise, Portland's Guild's Lake district has been outside the planning area.

\section{THEORETICAL QUESTIONS}

Portland and Seattle are heralded for their emphasis on extensive citizen participation. Both cities are consciously inclusive and process-oriented. A wide range of positions put forth by different groups, none with a monopoly on resources, is supposed to result in public policy in the public interest. The fairness of these processes is based upon the pluralist assumption that influence is dispersed.

\section{Pluralism}

Portland and Seattle political leaders subscribe to Robert Dahl's description of the city as a forum in which political demands of different groups with different interests are represented. No group has a monopoly of resources nor devotes all of its resources to 
politics. Political leaders are interested in winning re-election, most eligible voters participate, and most voters are knowledgeable and disinterested and have a real choice among alternative policies put forth by rival candidates. The political system works because there is a consensus about basic views.

Dahl's study of New Haven found that "fundamental aspects of the social, economic, and political structures of New Haven" had fragmented "a system of cumulative inequalities in political resources" into "a system of noncumulative or dispersed inequalities in political resources." Dahl hypothesized that:

1. Many different kinds of resources for influencing officials are available to different citizens.

2. With few exceptions, these resources are unequally distributed.

3. Individuals best off in their access to one kind of resource are often badly off with respect to many other resources.

4. No single influence dominates all the others in all or even in most key decisions.

5. With some exceptions, an influence resource is effective in some issue-areas or in some specific decisions but not in all.

6. Virtually no one, and certainly no group of more than a few individuals, is entirely lacking in some influence resources. 41 Contrary to Dahl's model of open competition among political agendas, the theme of this dissertation is the strong desire in both cities to create an institutional framework to carry out policies to 
reinforce the business core, albeit with quality of life amenities. These policies called for continued growth. Cummings, Molotch, Whitt, Neubeck and Ratcliff, in Business Elites and Urban

Development describe this concentration of influence:

The political and economic essence of any given locality, in the present American context is growth.42 । [Molotch] further argue that the desire for growth provides the key operative motivation toward consensus for members of politically mobilized local elites, however split they might be on other issues, and that a common interest in growth is the overriding communality among important people in a given locale - at least insofar as they have any important local goals at all. Further, this growth imperative is the most important constraint upon available options for local initiative in social and economic reform. It is thus that I argue that the very essence of a locality is its operation as a growth machine. 43

Local businessmen who own property, financial institutions oriented toward local investments, profesșionals such as lawyers and realtors who directly benefit, and businessmen/politicians are typical members of the growth coalition. The metropolitan newspaper, university, and utilities also support growth because general economic growth enlarges their client base. The latter become growth statesmen rather than advocates for a particular distribution of growth. The agenda is controlled so that

the issues which are allowed to be discussed and the positions which the politicians take on them derive from the world views of those who come from certain sectors of the business and professional class and the need which they have to whip up public sentiment without allowing distributive issues to become part of public discussion. 44 
City Limits

Paul Peterson writes that the conflict between efficiency and equity also limits public debate.

Within a federal system the objectives of central and local governments stand in contrast to one another. Local governments are more concerned about operating efficiently in order to protect their economic base, while the domestic policy structure of the national government is more concerned about achieving a balance between developmental and redistributive objectives... The emphasis local governments place on efficiency at the expense of equality is due not to any antiegalitarian commitments of local policymakers but to the constraints under which local governments operate. In order to protect the economic well-being of the community, the government must maximize the benefit/tax ratio for the average taxpayer. 45

Public debate is appropriate only when the probable economic impacts of policies "is so problematic that reasonable individuals can disagree about their effects."46 These are typically allocational policies such as where public facilities are to be built or general housekeeping issues such as garbage collection or civil-service employment. Peterson comments that Dahl's pluralist theory may be an appropriate theoretical framework to discuss New Haven school politics. 47 But downtown development issues such as examined in this dissertation are developmental policies necessary to the city's well-being.

Peterson's emphasis on the limits of political choice, the restrictive "social and economic" context in which the city is embedded, 48 suggests that the focus of this dissertation is misplaced. These case studies should focus on broad national 
constraints, not just record the actions of local actors:

When developmental policies are considered, attempts to ascertain the power of one or another individual or group are probably pointless, if not misleading. In this policy arena the city as a whole has an interest that needs to be protected and enhanced. Policies of benefit to the city contribute to the prosperity of all residents. Downtown business benefits, but so do laborers desiring higher wages, homeowners hoping house values will rise, the unemployed seeking new jobs, and politicians aiming for reelection. 49

Peterson justifies the dominance of the pro-growth coalition:

Lower levels of citizen involvement in local politics can be understood as rational responses to the structural context in which the public finds itself. ...To the extent that local politics weakens the capacity for mass pressures, it allows for due consideration of city economic interests. At times the interest of one or another notable may run contrary to the economic interests of the city of the whole, but it is the interest of the disadvantaged which consistently come into conflict with economically productive policies. By keeping mass involvement at the local level to a minimum, serious pressures for policies contrary to the economic interest of cities are avoided.50

I believe that public resources are devoted quietly and swiftly to downtown issues because powerful interests are most concerned with downtown redevelopment. Neither pluralist politics nor economic necessity accounts for specific decisions. Pluralist theory would lead one to believe that a significant number of interests compete to determine specific public investment decisions, whereas decisions are based upon a mix of objective study and personal influence. Peterson's analysis, if correct, could lead one to believe that similar cities will follow similar 
developmental policies with similar results and similar low levels of conflict. (Peterson himself admits that the power structure approach gives a "quite convincing portrait of the local political landscape.")51 Is this borne out by our case studies?

\section{Urban Regimes}

Stephen Elkin proposes an "urban regime" model which responds to both Dahl's and Peterson's concerns. Urban politics is rooted in the political economy of the city:

The conceptual foundation on which my comprehensive interpretation rests is the division of labor between state and market as it has become manifest in cities. The interpretation attempts to move beyond the now sterile debate between elitists and pluralists that has characterized community-power studies - and takes seriously what common sense tells us, namely, that city politics is a profoundly economically oriented enterprise. It is bound up with economic matters in direct and powerful ways, so that there can be no study of city politics without the study of city economy. Moreover, the nature of the city's concern with its economic destiny, the extent of its public powers and their internal organization- in short, the principal features of the state-market division- are all historically shaped." 52

Elkin lists several features of city politics which undermine a pure pluralist characterization of local politics. Elections rarely provide a referendum on development policy. City bureaucracies are central actors in city policies. These bureaucracies are so interested in growth in the local economy that city officials seek local businessmen's direction. Bureaucracies have autonomy on dayto-day running of the city and have significant influence on major policy and budgetary decisions. 
Elkin calls attention to three pairs of linkages:

1) the extent to which the land use alliance shapes the activities of the functional bureaucracies, how its efforts to do so are carried out and the pattern of resistance, if any, of the leadership of city bureaucracies to these efforts,

2) the extent to which the personnel and resources of city agencies are part of electoral coalitions, including whether city politicians regularly penetrate the bureaucracy for electoral advantage.

3) the extent to which the alliance between land interests and local politicians is a crucial part of the electoral organization created by politicians, including whether land interests contribute resources and are themselves candidates for office.53

Elkin provides an historical overview of the "continuities" which have served as the building blocks of different city political patterns or "urban regimes." As the nation's economic history has evolved, dominant regime types have succeeded each other. Nineteenth Century privatist regimes turned Twentieth Century pluralist; then federalist; and then entrepreneurial. Elkins's description of the complex entrepreneurial regime provides a focus for this study:

The shape of the political economy is still emerging. But the implications for the broad character of the relationship between business interests and public officials can be discerned ... Even in the context of more politically difficult land-use strategies for promoting city growth and of changes in the political arrangements, public officials are still drawn to policies that promote the economic growth of the city. They are thus drawn into extensive links with business figures who share these purposes and whose cooperation is in any case 
required in order to pursue them. These links are, inevitably, different from those that existed under the pure entrepreneurial political economy. They are, in fact, more complex, not least because public officials are now themselves more diverse in their incentives and business interests are more fragmented. On balance, the relationship is one in which public officials play a stronger role than they did previously. This is partly because business interests are, in fact, more fragmented and partly because the problems are more complex and business executives lack the time to act as civic statesmen, thinking through proposals. In general, the relationship between public officials and business is more like a coalition than like the alliance that was characteristic of the pure entrepreneurial political economy. 54

This complex regime relies heavily on institutional arrangements which bureaucratic actors administer. City Hall promotes growth through sophisticated land use policy and specific project proposals.

This contradicts pluralism's assumption of dispersed influence and Peterson's re-definition of pro-growth bias as fundamentally fair because in the interest of the city as a whole. This research will refer to these linkages to explain the politics behind our case studies. For example, this study describes the success of the Portland Development Commission within the study period. Quasipublic institutions, such as development commissions, create the institutional context which constrains the public agenda. Development Commissions select projects which will facilitate growth and involve the public and private business sector in partnership. 55 


\section{Stratification}

In addition to identifying which linkages are most important to each city, this study should be able to examine in detail how these linkages work. Clarence Stone has restated stratification theory to indicate how the "durable features of the socioeconomic system confer advantages and disadvantages on groups in ways that predispose public officials to favor downtown business interests."56

Social structure in cities is of a diamond shape - a small top stratum, a large (and multiple) middle strata and a relatively small bottom stratum. The top stratum has three advantages over the more populous middle class: economic position, hierarchical position and social position or lifestyle. Economically, the top stratum has great wealth and command of major economic enterprises; politicians favor the top stratum as these revenue produces are essential to institutional maintenance. Elite associational groups are small and can act quickly and devote substantial resources to any project. The high social status of the top stratum exerts an allure.

Given the likelihood that public officials, elected and appointed, will want to enhance their own careers and assure the well-being of the organizational units they are affiliated with, their behavior will be patterned by the system of stratification. Specifically, systemic power grows out the fact that as officeholders make decisions, they take into account: (1) economic considerations - especially the government's revenue needs; (2) associational considerations - capabilities of various groups to engage in and sustain policy and other goal-oriented actions; and (3) social status and life- 
style considerations - especially as they bear on professional and career accomplishments. 57 ... This positional bias results in system power in which top stratum business interests are indirectly powerful. Public officials are subconsciously predisposed to favor business interests.

Figure 9 presents a more sophisticated treatment of interest demand generation and conversion. 58

Systemic power comes into play during the "demand conversion" phase. Action or inaction on articulated demands are grouped into three stages: (1) mobilization - the stage at which proposals may or may not receive enough support to be brought up for formal consideration by local authorities; (2) official disposition - the stage at which officials formally decide to approve, either fully or in substantially modified form, or disapprove proposals; and (3) implementation - the stage at which it can be determined whether or not after gaining official approval proposals have been put into effect and if so, to what extent.

Finally, Elkin's linkages assume that the land use alliance. controls electoral contests. Elkin's second and third linkages involve electoral coalitions but voters do not decide alternative policy choices. The fundamental questions is: Can citizens make a difference? Dahl provides hope that not all influence is beyond the reach of a committed activist. Elkin and Stone cast doubt that the urban regime with its inherent advantage can be beaten. Peterson thinks that the activist is misguided. Yet we desire local democratic decisions. I suggest three research questions for our six 


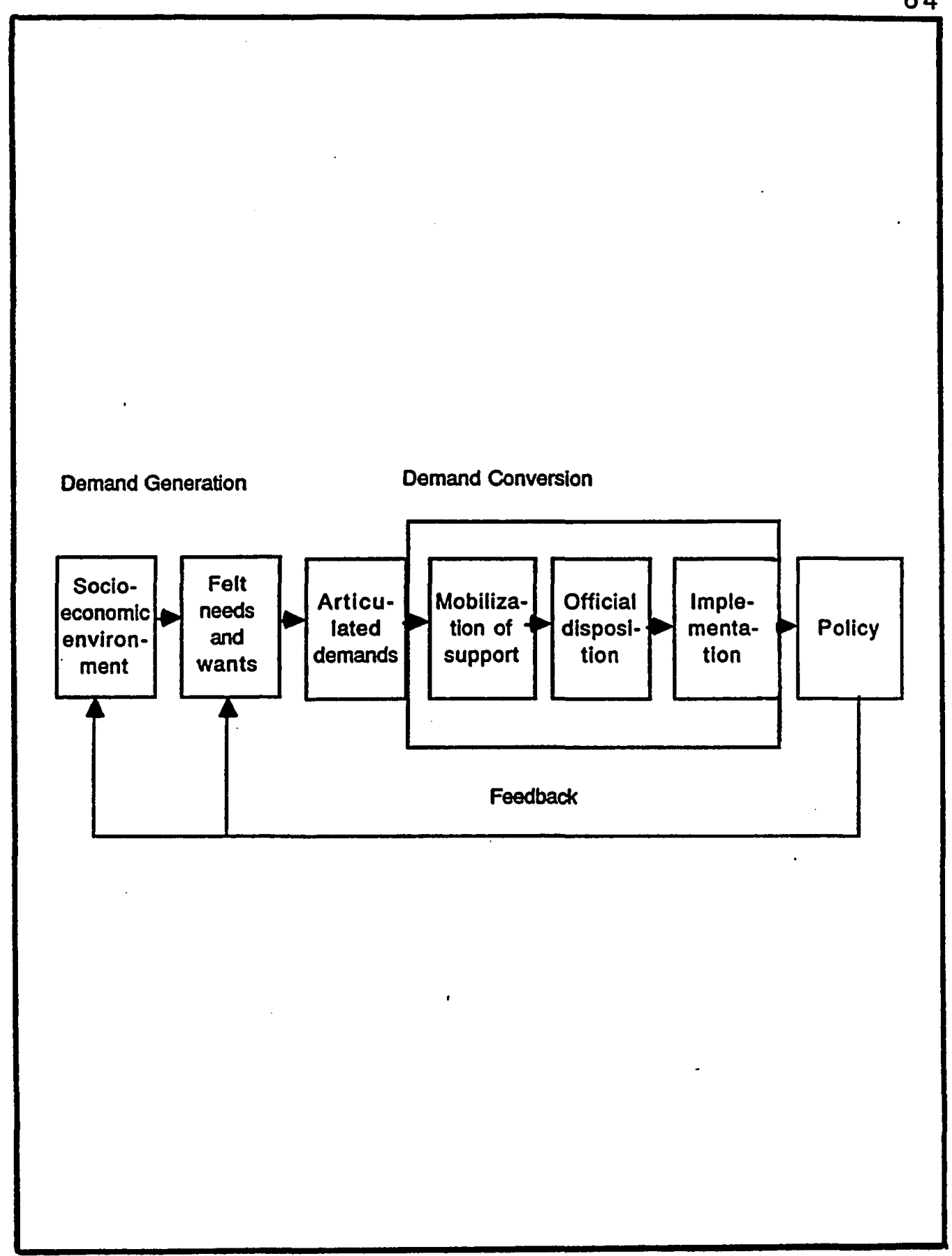

Figure 9. Systemic Bias. From Clarence Stone, Economic Growth and Neighborhood Discontent. System Bias in the Urban Renewal Program of Atlanta (1976). 
case studies which provide a means of examining the extent to which each city furthers or thwarts democratic citizen participation:

1. How does the urban regime operate in each city? Is each regime in Portland and Seattle equally effective? Do business and City Hall collude on every issue to their advantage?

2. How does the jobs argument affect the ability of activists to envision alternative policies to those put forward by the urban regime?

3. Can activists mount a challenge at the ballot box? Can activists organize and create an alternative to the existing urban regime? 
ENDNOTES

${ }^{1}$ Otis Dudley Duncan, Metropolis and Region, p. 334.

${ }^{2}$ City of Seattle, Office of Long-range Planning, Comprehensive Plan Framework Pollicies, Economy Backoround Document.

${ }^{3}$ Most of the phenomenal growth attributed to Puget Sound is attributable to the statistical decision by the U.S. Census to combine the old Seattle-Everett and Tacoma SMSA's. This chart quotes statistics for the four countles surrounding Portland and the two counties surrounding Seattle. The four counties surrounding Portland are Multnomah, Clackamas and Washington Counties, Oregon; and Clark County, Washington. The two counties surrounding Seattle are King and Snohomish.

4The figures for Portland are based upon Metro assumptions as reported by Karen Myers \& Associates in the study, Central Clity Plannine Area Office Market Study, March, 1986. The Puget Sound region grew by $2.4 \%$ during the 1980 's according to the Puget Sound Council of Governments as reported in the Seattle, Office of Long-range Planning report, Economy and Employment Comprehensive Plan Backoround Paper, 1990.

5Unfortunately, these local data were collected specifically for downtown planning efforts at different times. The Portland data, collected in 1987, reflected the recovery from the recession early in the decade while the Seattle data were collected in 1980.

6Portland Development Commission, Central City Plan Briefing Paper 4: Historical and Current Retall Activity in the Portland Metropolitan Ares, March, 1986.

7 Puget Sound Council of Governments, Economic Profile of Seattle CBD, 1982-1987, page 10 and Table 5, "1977 Retails Sales (Establishments with payrolls)" and Table 6, "1982 Retail Sales (Establishments with payrolls)."

${ }^{8}$ Association for Portland Progress, "Outlook 2000," August, 1990. Puget Sound Council of Governments (PSCOG), Economic Profile of Seattle CBD Economic Activity, 1982 1986, Table 3, "Prime Office Space Inventory." Land Use and Transportation Project Draft Environmental Impact Statement. Portland figures include Class $\mathrm{C}$ office space. Seattle's Prime Office space alone was projected to increase to $19,486,820$ sq. ft. by 1987 . However, as of the beginning of 1993 , Seattle's downtown office vacancy rate was approximately $20 \%$, about double that for Portland.

${ }^{9}$ Carl Abbott, Portland, p. 156.

10 Mark Sidran, Middle -Class Urban Pollitical Conflict: The Case of Seattle, p. 6. George W. Scott, "The New Order of Cincinnatus, Municipal Politics in Seattle During the 1930's," Pacific Nerthwest Quarterly 64 (October, 1973): 137 - 46.

11 Sidran, page 7.

12Delbert C. Miller, International Community Power Structure, p. 72. 
13 Banfield, p. 41.

${ }^{14}$ Sidran, p. 12.

15Edward C. Banfield, Big_city Politics, p. 134, quoted by Sidran, p. 8

16 Abbott, p. 170.

${ }^{17}$ Oregon Journal, "Residents, merchants, sad, bitter as renewal area move-out nears," May 24, 1959, p. 1.

${ }^{18}$ Arqus, "Elect A New Slate," August 13, 1965.

19 Sidran, p. 7.

${ }^{20}$ Oregenian, "Downtown Boosters Quietly Fade Away," February 24, 1965

21David Brewster, Arous, "Sweeping Downtown Plan Unites Portland," March 3, 1972, p. 1. Abbott describes downtown planning efforts in his book, Portland. Chapter 10 is titled "Saving the Center: Downtown Planning, 1957 - 80."

22Dick Brainard, "Memorandum, Downtown Plan - Central City Plan Relationships," March 1, 1984.

${ }^{23}$ City of Portland, Downtown Plan:_Planning Guidelines. "Commerce Goal."

${ }^{24}$ City of Portland, Bureau of Planning, Rudy Brunner Award Application, p. 1.

${ }^{25}$ Oregonian, "City Club Record Report urges city to abolish renewal body," August 13, 1971.

26The old guard was replaced during Goldschmidt's tenure - Ira Keller resigned in 1972; Ned Look resigned in 1973; Kenward left in 1975.

${ }^{27}$ Oregenian, "OPD calls for Commission reform," November 25, 1977.

${ }^{28}$ Oregonian, "Amended sult says hotel violates plan," January 17, 1978.

${ }^{29}$ Seattle 2000 Commission, Goals for Seattle 200, 1973, p. 31.

${ }^{30}$ Seattle 2000 Commission, Goals for Seattle 2000, "Goal A, Diversity and Freedom of Choice, Goal IIA, The Center of the Region."

31 Linda Dalton, "Polttics and Planning Agency Performance," p. 194, quoting David Brewster, Seattle Weekly, "Rediscovering government: By reorganizing city hall Mayor Royer has unearthed a forgotten asset - and discovered himself," February 27, March 4, 1980, p 12. 
32Nancy Debaste, Vicki Murphy, Alexandra Pye, Carl Warren and Hillary Hamilton, Chair, Seattle League of Women Voters, Neighborhood Planning in Seattle, p. S-6.

${ }^{33}$ Characterization of Royer's 1987 Mayoral campaign support by Rich Ray, "Urban Development and the Co-optation of the People's Mayor, Arcade, February/March, 1989, p. 1.

34The 1980 city-wide Comprehensive Plan raised density issues in the neighborhoods but these remained unconnected to the core.

35Sue Taoka, Special Assistant to the Mayor, Your City: Seattle Works in the 1990s, Seattle: no date, p. 20.

36 A note on formal political institutions: Portland continued its Commission form of government during this period. The Mayor held but one vote on Council but chose who would oversee the Development Commission, Bureau of Planning and Transportation Bureau. The Mayor also submitted a budget. The Mayor oversaw the Development Commission during this period. Thus, the Mayor initiated urban renewal projects and agreed to fund planning initiatives. Seattle continued with a "strong-Mayor, strong-Council" form of government. The Mayor initiated both planning and projects but Council had to ratify these plans and projects. The Seattle City Council sometimes established committees to oversee the work.

Formal electoral requirements for non-partisan, at-large electoral requirements were the same in both cities. This "reform" program strengthens the position of upper-status professionals associated with the promotion of downtown. Citizen participation involves "blueribbon committees" rather than low-status or unorganized groups.

37U.S. Census, Table 1, "Selected Population and Housing Characteristics," 1990. State and Metro Area Data Book, "Table C. Citles," 1986.

${ }^{38}$ This area also includes Seattle's Lake Union and First Hill.

${ }^{39}$ Seattle, Office of Long Range Planning, Land Use and Transportation Project (LUTP), Table 37, "1982-2000 Change in Downtown Housing by Type," Table 39A "Downtown Low Income Housing Program: Proposed Action." The Seattle Downtown Study area Includes an expanded International District.

40LUTP, Table 34, "Regional Housing Impacts by Downtown Plan Alternative."

41Robert A. Dahl, Who Governs: Democracy and Power in an American Clty, p. 228. Dahl's italics.

42 See also Logan and Molotch. Urban Fortunes. The Political Economy of Place. Berkeley. University of Callfornia Press. 1987.

43. Harvey Molotch. "The Clty as a Growth Machine: Toward a Political Economy of Place," A.J Volume 8?. Number 2, D. 310.

44Molotch, D. 318. 


\section{5 paul E. Peterson, City Limits. D. 68 and 0. 71}

46paul E. Peterson, Clity Limits, p. 150.

47Peterson defines developmental policies as those which guarantee more revenue than expenditure. Those policies which incur more costs than revenue are redistributive and those policies which are neutral are allocational.

${ }^{48}$ Peterson, p. xil

49 Peterson, p. 147.

50Peterson, pp. 128-129.

51 Peterson, p. 5.

52Stephen L. Elkin,. City and Regime in the American Republic, , p. 7.

${ }^{53}$ Elkin, "Twentieth Century Urban Regimes," p. 14.

54 Elkin/Stone, p. 43.

${ }^{55}$ Elkin, City and Regime in the American Republic, pp. 41-42.

56 Clarence Stone, "Systemic Power in Community Decision Making: A Restatement of Stratification Theory," American Political Science Review, 74, 3. p. 159.

57Stone, p. 168.

58 Stone, Economic Growth and Nejahborhood Discontent: System Bias in the Urban Renewal Program of Atlanta, p. 21. 
CHAPTER III

PORTLAND: FROM DOWNTOWN PLAN TO CENTRAL CITY PLAN

\section{NEW CHALENGES}

As described in the previous chapter, the Downtown Plan revitalized the west side downtown by providing the framework for massive public investment in transit, parks and commercial development. ${ }^{1}$ New issues also arose at the start of the 1980's which suggested new action by the City. Downtown - circumscribed by the rail yards to the north, the 1-405 freeway to the west and south and the Willamette River to the east - continued to lose market share to the suburbs. And suburban-style commercial development was possible just beyond downtown borders. Downtown parking restrictions did not apply beyond the freeway loop. New projects to the north and south along the river and in Lloyd Center benefited by the attractions of the core and centrality. In these peripheral areas, excellent access to highways was complemented by free extensive parking. Lloyd Center had the space and the intention to build a new office tower every three to five years. The Association for Portland Progress (APP), the west side downtown business association, identified parking restrictions as the chief drag on its efforts to maintain market share.

The Portland Development Commission was completing the 1970 's downtown development agenda with the development of 
projects such as Pioneer Courthouse Square, the Portland Center for the Performing Arts, a retail anchor project on Morrison, the South Waterfront Project, KOIN Fountain Plaza, South Park Blocks improvements, and relocation of the bus station. At the same time it was clear that the Banfield light-rail system and its proposed westside extension would significantly affect the Lloyd Center/Coliseum, North of Burnside and the Northwest Triangle districts. The recession had hit Oregon hard; the city was having difficulty marketing the retail core anchor project to potential investors or tenants. Redevelopment of the North of Burnside area had stalled. Hopes for a Portland version of Georgetown were dimming in the face of continued conflicts between local merchants, transients and social service agencies. It appeared that downtown might not capture the new convention center. ${ }^{2}$ Influential downtown business people such as John Russell, Greg Baldwin and Louis Scherzer therefore felt that an update of the Downtown Plan was essential.

\section{CENTRAL CITY PLAN: UPDATING THE DOWNTOWN PLAN}

In October, 1983, Commissioner Margaret Strachan's office proposed a "Central City Plan" (CCP). The Plan was partly a counter proposal to APP's attack on the downtown parking lid and partly a recognition that the Downtown Plan needed a new agenda. Strachan's chief aide, Richard Forester, wrote a Council resolution which called for a review of the downtown plan and the urban renewal plan. This review would include a Central City parking, transportation 
and traffic plan to enhance "the role of downtown as a mass transportation hub of the region." 3 The Central City would include downtown west of the Willamette River, Skid Road (North of Burnside), an adjacent immigrant neighborhood (Goose Hollow), railyards and industrial land adjacent to the west side downtown (Northwest Triangle, the Macadam Corridor), and areas east of the Willamette (the Central Eastside and Lloyd Center). Forester and Michael Harrison, a senior planner at the Planning Bureau, had enlarged the scope of concern from parking supply to the diminishing role of the core in the still suburbanizing region. This was a replay of the Downtown Plan's evolution.

After two months of discussion and the circulation of ten preliminary drafts, Strachan went public at the beginning of 1984 with a Council resolution creating a broad-based citizen-driven planning process (Figure 10 illustrates neighborhood and business association territories). The Commissioner or her staff had contacted prominent businessmen such as Doug Goodman, John Russell, Bill Naito, Melvin Mark, Pete Marks, Bill Wyatt (APP) and others and found support for the update 4 . In the two months of public discussion, Strachan and her staff called or wrote almost 300 interested parties - business people and organizations from each geographic area, neighborhood organizations, politicians, consultants, influentials, etc. 5 Widespread support for the plan focused on the need to update the Downtown Plan. The disparate nature of this support was disguised because the Downtown Plan had promised so many different results - economic development, humane 


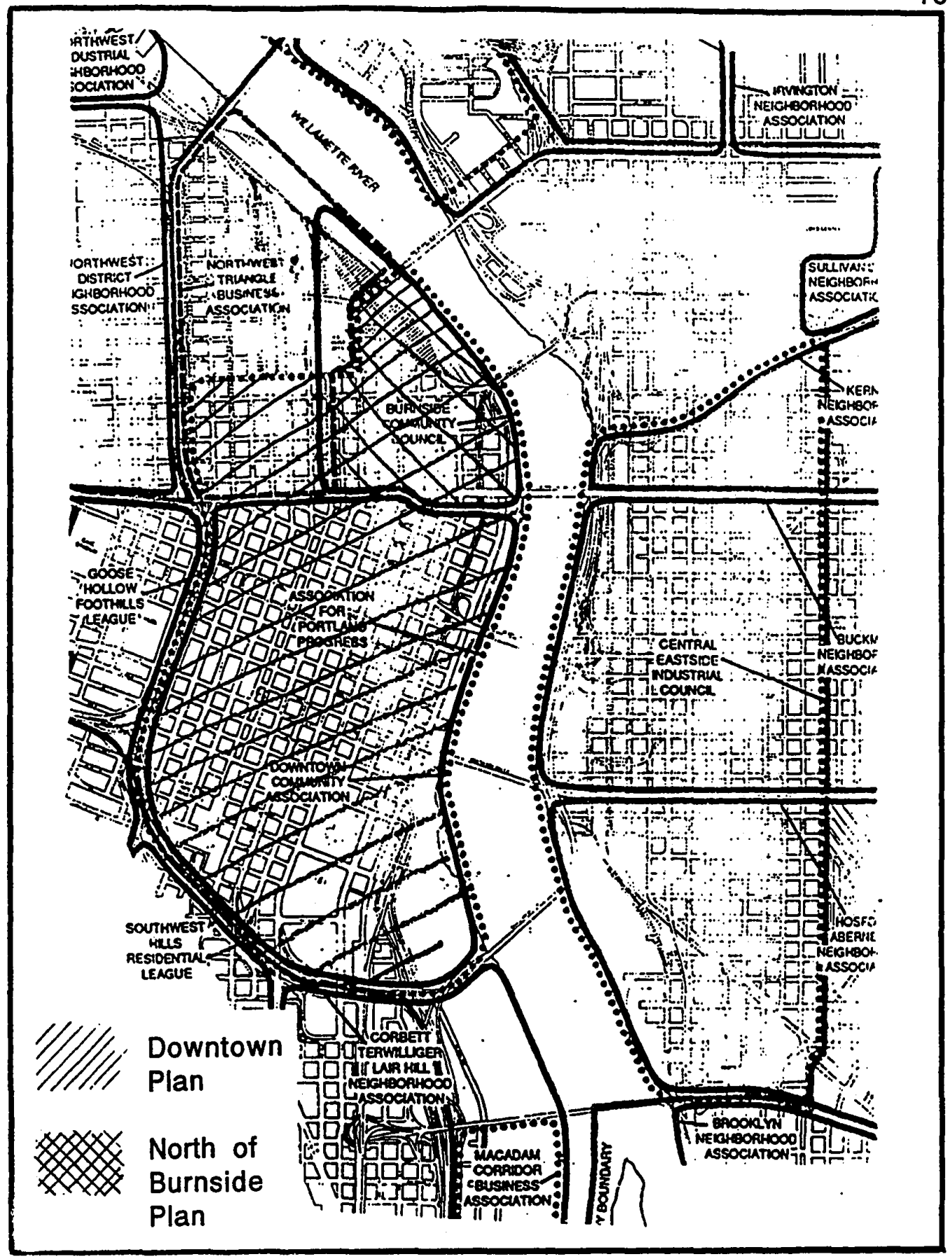

Figure 10. Neighborhood and Business Association Boundaries. From City of Portland, Central City Plan (1988) 
design and replacement housing. In particular, westside business interests focused on the private investment leveraged by the big Downtown Plan projects such as the transit mall. ${ }^{6}$ These business interests saw a chance to include the east side and other west bank areas that had profited by the Downtown Plan effort while escaping parking and design restrictions.

The chief obstacle to this initiative was Mayor Frank Ivancie's antipathy to planning. Ivancie had appointed Terry Sandblast as Planning Director. Sandblast had formerly staffed an eastside commercial strip business association. These small business people were opposed to additional core planning initiatives as a diversion of resources. Strachan sought to circumvent this difficulty by creating an independent effort that would not directly involve the Planning Bureau. With Council and business community support for Strachan's initiative, Mayor Ivancie reluctantly supported an update. Ivancie and Strachan compromised over the location of the effort, placing it as a separate unit within the Bureau of Planning rather than an independent city office. As part of the compromise, Ivancie and Strachan jointly selected the "pre-planning committee" charged to make a proposal to Council for the organization. and content of the plan. Mayor Ivancie insisted on Sandblast's participation.7

The pre-planning committee included Strachan as chair; PDC Executive Director Patrick L. LaCrosse, vice-chair; Sandblast, William W. Wyatt of the business lobby group, the Association for Portland Progress; Donald H. Lengacher of PGE (the westside electric utility) and CEIC (the Central Eastside Industrial Council); and Don K. 
Stastny (an architect and supporter of Strachan). The pre-planning committee was responsible for defining the powers of the citizen committee, its composition and size and its relationship to all other city commissions and review bodies. Ultimately, relationships with the Planning Commission and Development Commission would be most crucial to the outcome of the plan. The pre-planning committee was guided by consultants. Don Barney \& Associates coordinated publicity, meeting logistics, data requirements and funding generally. Other consultants also included planner Dick Brainard, who had worked on the Downtown Plan at $\mathrm{CH} 2 \mathrm{MHill}$, and Don Stastny who provided planning advice and who authored the citizen-based, reiterative process eventually used.

\section{Process}

On July 25, 1984 the Portland City Council adopted the planning process which would guide the plan for the next $21 / 2$ years. This process would consist of three phases - development of a broad vision for the Central City, translation of the vision into "performance goals," and transformation of the goals into an implementation plan. The final result would be a draft plan which would inciude a vision statement, performance goals, public actions, and potential private responses required to implement the plan. Each of these products would be reviewed by the Planning Commission and ultimately adopted by City Council. 8 The plan called for an innovative public outreach effort in the form of three "Design Events." Design events were series of events taking place over a two-week period involving organized groups and individuals from all 
over the community. Design Event One was to initiate the process of creating a broad vision. The kick-off took place on the center span of the Burnside Bridge. Balloons floated above the bridge in an arch which symbolized the binding of both sides of the river into a "Central City" core.

Design Event Two was to follow basic research and studies of the different districts. (District studies were never completed). Design event two was to result in a refined vision statement "in terms of performance goals that describe the City's expectations for the Central City in terms of housing, transportation, public amenities, urban design and other issues." Finally, Design Event Three was to take place to evaluate the feasibility of the refined vision statement. Design Event Three was to take place in Fall 1986 or Spring 1987, two or three years in the future.9

According to a consultant's presentation to the Planning Commission, the original intent had been to do a more traditional planning study in terms of citizen involvement. In a traditional study, experts isolate relevant facts and propose alternatives for citizen comment. But the pre-planning committee felt that a traditional planning process might not "jell.". In some ways, the plan process was an experiment, different from traditional planning or even from the mythicized Downtown Plan:

What we are charged with and are presenting to you is a process by which the vision of the city can be planned. One of the things that I [Don Barney] feel is inherent within this type of process is that it is different than a comprehensive planning process, it is different than a 
fairly, let's say, then, a traditional planning process. A traditional planning process, which is all that the planners are trained in, has to deal with a derivation of the scientific method of a data gathering, data analysis, hypothesis setting, testing hypothesis, down the line. A fully step-by-step rote approach to planning. What we have in Portland, and because of the structure that is here, with the comp. plan, the Downtown Plan, we have the luxury of developing a new type of planning process that takes planning, or the ability to do planning, a step higher. So it enables us to: one, develop a vision for what the city can be, to test that vision down through a series of events within the city to come up with a final vision and guidelines of what and how to get to that particular point. 10

The attempt to be non-traditional, to be a national leader in an untried planning process, would mean unforeseen difficulties. The Planning Commission acquiesced to the Central City Plan process because the process was explicitly laid out by Council resolution. Planning Commissioner Richard Bentley did question whether the project would suffer from the lack of specific timelines. The dialogue between the consultant and Planning Commissioner Bentley foreshadowed the tension between process and product. Strachan's plan represented process. Her theme was that good process led to good product.11

\section{Critical Issues}

At the very beginning of the process, the consultants reported to the committee on the crucial issues which the Central City Plan would confront: 
From a development viewpoint, staff officials anticipate a possible debate over the future nature of the Central City. Right now, it is an area of great diversity, home of the region's highest paying jobs and some of its lowest paying jobs. A decision of the CCP may be whether to retain this diversity through the continued existence and creation of warehousing and light industrial uses, or to move basically toward office, as many core areas in other major metropolitan centers have done. Such a transition has already occurred in the south Macadam corridor, where $600-800$ light industrial jobs have been replaced by $2,000-3,000$ office-related jobs.

The status of the industrial sanctuary in the Central Eastside Industrial District (CEID) was one of the most important issues for the new Plan. New proposals for offices had recently been made. While the area's lower cost space was supportive of incubator industry, the "district's relationship to the river places it squarely at the table in the debate over recreation uses and public access points on the Willamette. All in all, the CEID is likely to be a real center of intensive discussion during the CCP development." The plan would also have to tackle the failure of the Downtown Plan in the area north of Burnside. 'The 'gentrification' of some of the Burnside area with successful office and retail ventures has produced co-existence problems between the business and the transient community that ought to be more vigorously addressed for the benefit of both populations through the CCP."12 (Changing public policy toward North of Burnside is treated in Chapter VI.)

The consultants also suggested that housing could be rebuilt in areas such as North Macadam and Central Eastside outside downtown. 
Balanced Representation

The Citizen Steering Committee was elaborately balanced. The steering committee consisted of 15 citizen members plus three exofficio members from the Planning Commission, Planning Bureau and Development Commission. There were four at-large representatives, including the chair, Don Stastny; four representatives of business/development interests in the Central City planning areas; four representatives of residential neighborhood interests within or immediately adjacent to the core; one design/planning representative (Sumner Sharpe, Strachan's husband); one social service representative and one representative from the arts community. The membership was "an upfront analysis of community power structure."13 The members were picked by Strachan and Ivancie. To make the committee even more representative, candidates who could represent more than one view were favored. For example, Mary Burki held a Ph.D. in urban affairs, was a past president of the Downtown Community Association, and was a housing specialist for a North of Burnside social service agency. Betsy Lindsay represented her Corbett-Terwilliger neighborhood and the Art Museum where she taught. Commissioner Strachan made it very clear that the plan was to be a citizen-driven process and emphasized the great length of time and effort spent organizing the planning process - six months, 17 public meetings, three public hearings, and participation by several hundred individuals. ${ }^{14}$

The Citizen Steering Committee would "prepare and review" the plan. The role of the Planning Commission would be limited to 
recommendations to the City Council for formal approval, although the Planning Commission was assured of and given periodic briefings along the way. The CSC, as it was called, would be assisted by a Management Support Team. Its function would be to coordinate technical/bureau people and citizen committees. Citizen committees were envisioned to be divided into three parts Research Advisory Committee, Special Issue Committee, and District Advisory Committee. The first two committees were combined, the latter committee was never constituted.

The most important aspect of the Management Support Team was that it was not headed by a planner or outside planning consultant, despite the positive experience of the Downtown Plan. The CCP Manager was specifically intended to be a nonplanner - "a senior level professional with project management and policy development experience." Urban design or planning experience was "desirable." 15 Dean Smith, a resident of the plan area, directed the effort as Plan Manager. Smith had previously served as Strachan's assistant and before that as Don Clark's public affairs assistant. His background was public administration, journalism and neighborhood politics. Staff to the plan included citizen-involvement planner Jim Owens and Rod O'Hiser, who had staffed the Downtown Plan. O'Hiser was the only Bureau of Planning employee on the project.

\section{Plan Purpose}

The mission statement, purpose and objectives clearly called for the elaboration and extension of the Downtown Plan's emphasis on economic growth and preservation of amenities: 
Mission ... To develop a plan that is a vision of the future, establishes the Portland central area as the center of commerce and cultural activity in the community, recognizes the unique environmental setting and historic precedence of the area, incorporates the residential and business characteristics of the individual districts within the area, preserves the integrity of adjacent neighborhoods, and improves the livability of the area for all citizens."

The CCP was intended to build upon the Downtown Plan, to lure additional investment to the core and to meld the individual districts into a cohesive Central City core. The CCP would be comprehensive, and would tackle unresolved housing, social service and parking issues:

Objectives... Planning issues to be considered include, but are not necessarily limited to, urban form and design, land use, transportation, housing, pedestrian environment and historic preservation; riverfront use; retail, commercial and industrial development; social services; public and private education, convention/tourism; cultural entertainment and recreation activities.

The plan would "Clarify the functional role of the Central City and its relationship to the community." 16 The former reference to competition for new office space among downtown and Lloyd Center and Macadam had been downplayed, as well as the failure of the Downtown Plan to address the loss of housing and the lack of a social policy. The press briefly discussed the difficulties of planning for such a balkanized area but participants were optimistic. 17 
With the exception of the Lair Hill neighborhood there was total community support for the plan before Council.18 Lair Hill still remembered its partial destruction by the South Auditorium urban renewal project. Downtown growth as a city-wide issue, affecting housing affordability or the quality of life was not considered to extend beyond actual plan boundaries. As long as the boundaries were kept tight, no neighborhood or environmental coalitions would fight downtown growth as in Seattle. (See Chapter IV.)

The period from Council approval in July 1984 to the following January was devoted to choosing representatives for the Citizen Steering Committee (CSC). The process was so lengthy because the process was elaborate. Sixteen neighborhoods within and adjacent to the CCP area were allotted four spaces. Since each neighborhood submitted three names, 48 people competed for four spaces. The plan sought participants who could count as "two-fers" and "threefers" and were new to city politics. ${ }^{19}$ The plan sought to create a multiplicity of interests, in conscious homage to pluralist theory. The members of the CSC were expected to make decisions on a consensus basis and within the confines of the meeting room.

\section{Design Event One}

Design Event One was an elaborate community outreach project, designed by a Portland public relations firm. On May 18, 1985, Portlanders were invited to celebrate the plan with a Burnside Bridge party. At noon, after the reading of the Mayor's proclamation, the "Dreamspan" balloon arch which symbolically linked west and east sides, was released into the air to begin the fun. What followed 
was an elaborate series of six city-wide and fifty neighborhood workshops; a ballot distributed via The Oregonian; intercept surveys of senior citizens, youths and tourists; a 1,000 person telephone survey; Tri-met placards; children's "Kid-mapping Project;" a mobile van with interactive computers; displays and a slide show touring Portland and visiting shopping centers; and Rose Festival events - all programmed to "allow people to define the specific issues of concern to them personally."20 " The standard mailing list contained 627 names of citizens, officials, community and business organizations.

The outreach theme was "Portland - Give Us Your Dreams to Build A Plan On." This slogan suggested the experimental, nontraditional, even visionary nature of the process created by Don Stastny. In the future, supporters of the original process would cite citizen input from this Design Event as evidence of local and democratic support for significant planning efforts. For example, proponents of moving the 1-5 freeway off the east bank of the Willamette would castigate decisions to retain its location on the riverbank as a betrayal of the public's desire to return to the river. Others would call Design Event One a farce, ridiculing the idea that the 10,000 Portlanders who may have stopped by a workshop or played with the computer were serious bargainers in the politics of city planning.

Design Event One results were painstakingly itemized by staff in twenty functional areas. Staff summarized broad issues and inventoried specific issues. The issue statements were intended to 
be used as a basis for research during phase two. These functional areas included commercial/industrial development, convention/tourism, cultural/entertainment, education, government, historic preservation, livability, natural environment, parking, pedestrian environment, public safety, recreation and parks, retail, riverfront social services, transportation, urban development and jobs. Responses were tabulated as apparent "consensus," "controversial" and "extremely controversial." The extent to which these values influenced the steering committee is unclear. In the CCP final write-up, the planning staff relied instead upon the proposals of the Functional Advisory Committees (FACs). 21

\section{Functional Advisory Committees}

The Functional Advisory Committees (originally called Research Advisory Committees) were created to review the research to commence at the beginning of Phase Two. Potential committee members applied and were appointed on the basis of expertise. In addition to receiving technical reports from consultants and bureaus, the members were supposed to suggest implementation options. In essence, the Functional Advisory Committees became eight separate citizen idea committees. It would be their reports which would provide the "1000 ideas" considered by the Planning Bureau. The original Functional Advisory Committees looked at economic development, recreation and environment, land use and housing, transportation, culture/entertainment and education, social services and public safety. Approximately 50 research reports were commissioned at a cost of $\$ 300,000$. Despite this large expenditure, 
research money was not earmarked for social service planning, in part because a grant application to Fred Meyer charitable trust was not funded.22 Research on the 1-5 move was limited in scope. Much of the research would not be successfully transmitted to the CSC by the Functional Advisory Committees; many studies were useful only to those agencies such as PDC who were skilled in using data to prove a point. These committees represented a lower level of citizen activism. They did not have access to decision-makers.

New Actors: the Urban Design Advisory Team

At the same time that the steering committee was confronted with massive citizen input, the Urban Design Advisory Team was created. This team was modeled on the national program of the American Institute of Architects which sent design professionals to give vision to redevelopment efforts. The Central City Plan team consisted of three prominent local architects, George Crandall, Paddy Tillett, and Will Martin as well as the nationally-prominent Berkeley planner Alan Jacobs. (Seeking design advice from San Francisco was a Portland planning tradition.) This team of four was responsible for creating the design vision for the steering committee. Will Martin, a romantic visionary began to speak about a pedestrian "ponte vecchio." After Martin's untimely death in September 1985, George Crandall would lead the team in critiquing process and product. Ultimately, he would actively move the team's focus to the very center of controversy - the future of the Central Eastside. The Central Eastside could not remain an industrial 
sanctuary and also redevelop with new mixed use development on the east bank of the river.

\section{Overload}

By September it was clear that the process was too complex and the information to be considered was too great. During this period both PDC and the Planning Commission chafed at the lack of a direct role in the plan.23 Coordination among all aspects of the project suffered from the large amount of work required of the management team. Some members of the steering committee became detached from the process. 24

A cleavage between the process "visionaries," and the pragmatists began to develop. The UDAT team, now led by Crandall, began to critique the process. This exposed the narrow representative positioning of most CSC members and the unwieldliness of a 25 member group. The CSC membership was so parochial that no one could take a position based upon the merits of an argument from a city-wide perspective. Discussion was difficult as the CSC jumped from issue to issue, sidestepping the crucial Central Eastside land use and transportation concerns. Technical studies churned out by the consultants created unigested homework for committee members. 25

As a result of the standoff, the steering committee issued a particularly bloodless first draft of Goals and Policies by November 18, 1985. Economic Development, Convention/Tourism, Natural Environment, Housing, Parks and Recreation, Public Safety, Transportation and Pedestrian Environment were broad topics. Goal 
and Policy language was non-specific. The plan stated that "the Central City should operate as the economic center for the City of Portland, the State of Oregon and the Columbia Basin." PDC had strongly objected that the previous vision statement had overlooked economic development. Richard Forester, on Strachan's staff, also argued that jobs provided the basics of core revitalization. In contradictory fashion, the policies indirectly called for maintenance of the industrial sanctuary on the eastside while doing something about the blight of the eastbank freeway (the CSC was told that to move the freeway would threaten the continued viability of the east side and that the state was about to build needed freeway access to 1-5, the primary north-south freeway corridor in Portland). The Plan highlighted the desirability of these manufacturing and distribution businesses in the core by specifically calling for a continuation of manufacturing and distribution services. Somehow, without disturbing plans to create even more freeway on the water's edge, the "intrusion of 1-5 on the eastside waterfront should be reduced."26

\section{Phase Two}

After two years, and $\$ 350,000$ it was clear that only broad statements could pass muster with the heterogeneous steering committee. Furthermore, the CSC was weakened by divergent approaches to decision making. Most members were uncomfortable with the reiterative Design One, Design Two workshops.27 Decisionmaking itself was up for grabs. The Urban Design Advisory Team assumed that the planning process was within their professional 
ambit while the designers of the original process pursued their vision of a citizen-driven process. Also, the Pre-Planning Committee's distrust of parochial interests, inherited by the management team meant that district studies could not be trusted to be objective rather than parochial and biased.

At this point, organizational changes were instituted to create more of a planning environment. Ft. Wayne planner Norm Abbott was hired as Planning Director on the strength of his management ability. Strachan's office was confident that he could avoid further confusion. Abbott was given the impression that the project needed planning-style leadership. Of course, this raised the same problem as before in terms of two staffs with different orientations. Already the management team had been brought into the Bureau's budget process in a move engineered between the Planning Bureaiu and the budget office.28 When Bud Clark defeated Frank Ivancie in 1984, Margaret Strachan was assigned the Planning Bureau. By this point in time, onlookers were becoming polarized in their estimate of the plan. Strachan, her advisors, and some neighborhood activists saw the plan as visionary, citizen-driven, and systems-oriented. Business people, the UDAT team and some members of the CSC saw a leadership vacuum, lack of direction, wasted effort, and delay. According to some interviewees, the steering committee had difficulty in understanding the planners' method of presenting alternatives.

Norm Abbott convened a charette process to generate alternative land use patterns. Michael Harrison and other planners 
were brought in even though no dollars were officially budgeted for this extra work.29 The Planning Bureau, meeting with the UDAT team and the CSC management team created three alternative growth patterns for consideration by the steering committee: an automobile-oriented central city, a central core composed of selfcontained "urban villages," and a city built around an intensive transit system. The auto-oriented model required the least public intervention. This model assumed no new light rail construction and the continued development of large-scale office and industrial projects just outside of the westside downtown. The urban village concept suggested creation of intense development "cells" around parks or landmarks. These would be oriented to a service-based economy. A trolley would connect "cells." The transit oriented growth pattern proposed light rail lines to the west, north and south and the extension of the transit mall to Barbur Boulevard on the south. Intensive urban development would take place along transit lines. The first two alternatives were "straw men." It had already been decided to extend the light rail line to the west. That had been the trade-off as part 'of negotiations to create a light rail system. The downtown could not grow without better access to the western suburbs over the West Hills. The steering committee made its first decision in 18 months by adopting the transit alternative on June 23, 1986.

Selection of the intensive transit option did not necessarily dictate land use in the Central Eastside. Led by George Crandall, the Urban Design Advisory Team proposed a major alteration to the 
structure of the Central City. The architects called for a modified mixed use zone west of SE Union Avenue. By relaxing zoning prohibitions on housing and other uses excluding office, the east bank would redevelop despite the freeway. Only office uses would be prohibited to avoid competition with downtown and Lloyd Center This was nicknamed the "donut concept" and it allowed redevelopment even without moving the freeway (see Figure 11). The key objectives would be a two-sided central city core with active, intensive uses in a core transit loop on both sides of the river. The industrial sanctuary would be confined to the east between Union and SE 12th.30 The Planning staff and Development Commission/staff opposed this proposal. PDC was especially committed to an industrially-oriented Central Eastside urban renewal area. Industrial development was represented as providing roughly 17,000 jobs. (Actually, this was a relatively low employment density, spread over 400 blocks.) These industrial properties could successfully compete with the suburbs given the construction of the 1-5/McLoughlin ramps. The Bureau of Planning drafted a report supportive of the industrial sanctuary concept at the request of PDC. 31

The committee agreed with the UDAT team by a split margin, 8-5. The majority believed that increased activity, jobs and possibly some housing was the appropriate future, even if the freeway remained - the land was strategically positioned opposite downtown, the convention center was planned to the north and OMSI 


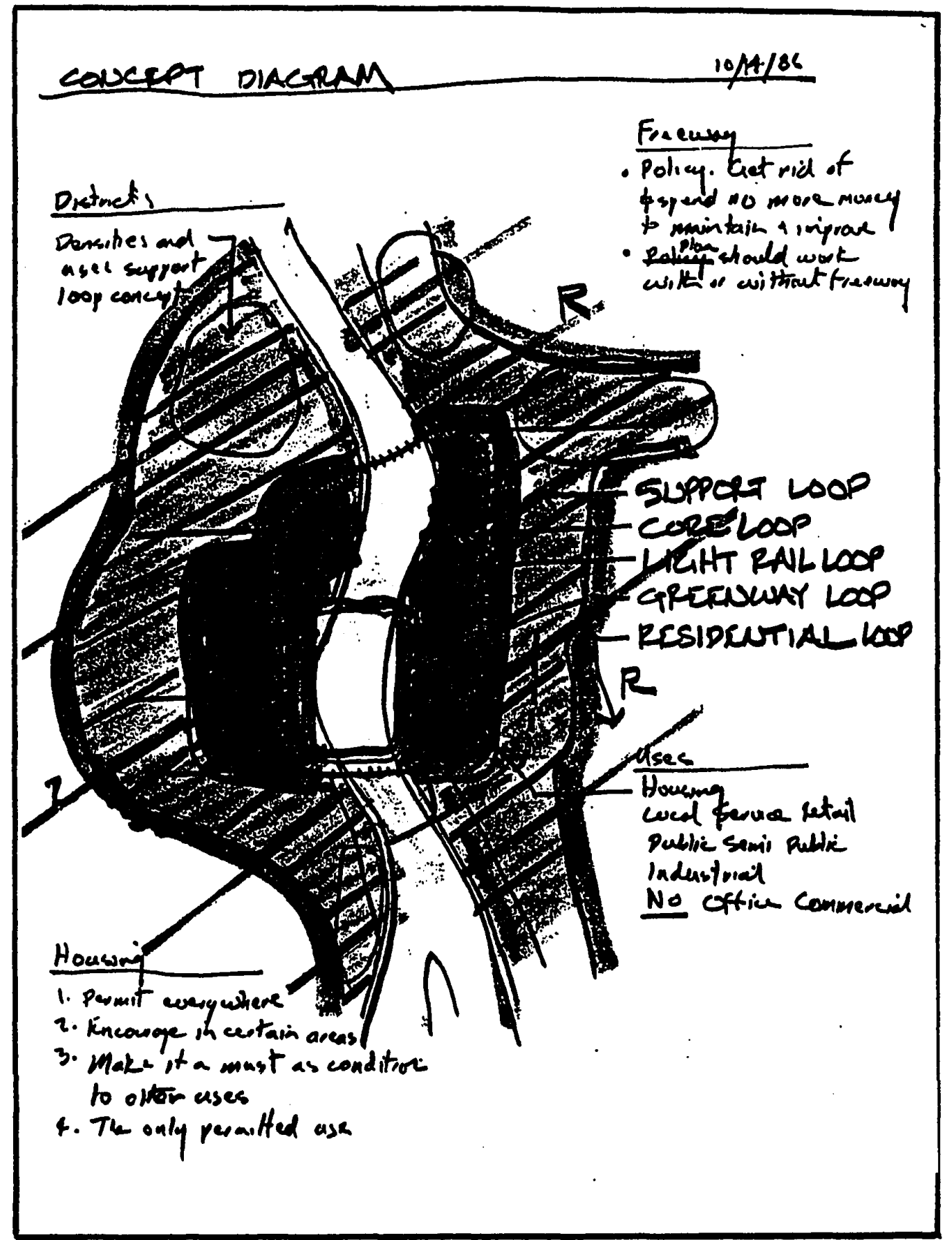

Figure 11. Central City Concept Diagram, George Crandall. 
to the south. Tom Walsh and the other steering committee members thought that redevelopment was inevitable.32. At the same time the steering committee proposed to lower permitted floor area along the Union/Grand corridor. The steering committee's version of a mixed use zone was billed as a higher intensity of uses and a richer mix "to create a two-sided city and to bring activity to the waterfront." Principal office uses were to be prohibited so that the area would not compete with Downtown or Lloyd Center. The market would create a third tier similar to that happening in the Northwest Triangle. (The tabloid also illustrated the industrial designation as an alternative.) $)^{33}$

Business and economic interest groups opposing this compromise included North/Northeast Boosters, the Central Eastside Industrial Council, PDC and the Economic Development Functional Advisory Committee. These groups thought the concept would have a destabilizing effect upon otherwise healthy business. Liberalizing permitted land uses while not moving the freeway was a fine distinction. Most of the CSC members could not understand this distinction. The location of 1-5 overrode all other discussions regarding land use and urban form

The 1-5 question split the steering committee. It did not help that the committee was presented with five different alternatives on August $1,1986$. The steering committee had originally commissioned private traffic consultant Robert Conradt and Oregon Department of Transportation official Tom Schwab to study the problem as a result of public sentiment expressed during Design 
Event One.34 As early as May, 1986 Conradt determined that the freeway could be moved. According to summary minutes, the steering committee took the position that moving the freeway was not feasible during the life of the plan but that the area near the east bank could redevelop "In order to satisfy a number of Central City Plan goals and policies, options for removal or relocation of the 1-5 freeway in the Central Eastside area have been explored. At the current time, removal or relocation of the freeway do not appear feasible... Beyond the 20 year scope of the Central City Plan is envisioned the removal of the 1-5 freeway within the Central Eastside and a restructuring of the inner-City freeway program. (Commissioner Strachan recalls that this decision was left for further study. Strachan had spoken of binding west and east side together - "not to re-create a downtown on the eastside.") 35 Don Lengacher had been representing the eastside since the pre-planning days to insure that this would not happen. Those motivated by urban design concerns - the architects, the Urban Design FAC and those interested in returning the river to the people - an ad hoc group called Riverfront for People - continued to push.

\section{Housing}

Several staff proposals that could increase the supply of housing were rejected. Housing designations along the North Park Blocks, west of the South Waterfront project, and along Southeast Harrison Street and Station $L$ in the Central Eastside were rejected. The steering committee set a goal of adding 4,700 housing units over the next two decades (6-4 vote) over the opposition of the 
Association for Portland Progress who feared that there would be no market demand. 36

The draft land use plan proposed new housing areas west of Lloyd Center, in the Northwest Triangle area and in the North Macadam district. Housing proposals were generally supported by the public. However, in North Macadam, property owners were opposed to housing or mixed-use projects. Property owners opposed residential zoning and cited inadequate market demand, poor environment and lack of infrastructure. While broad support for housing was expressed, the plan's objective of targeting 4700 new housing units in the next 20 years was questioned. The issue pitted the activists on the housing FAC against "realists" pointing to previous demand. Housing advocates and developers split over whether the railyards and sites along the river were suitable for housing and whether housing should be required or not. The Schnitzer/Zidell interests, who had controlled this area for their metal salvaging operations for many years but were about to go out of business. They were opposed to the staff's emphasis on housing and open space or park under the Marquam bridge. These interests wished for low-density office development, a marina and/or hotel.

At that point, the original plan process called for a second design event. Margaret Strachan had been defeated by a planning opponent, Bob Koch in November, 1986. Koch had campaigned against public expenditures for downtown planning. New commissioner Earl Blumenauer received the Planning Bureau assignment. 37 Norm Abbott prepared a memo to Commissioner-elect Earl Blumenauer, 
outlining two options for completion of the project. Both options would allow the CSC to complete its work and forward it to the Planning Commission and City Council for acceptance and future implementation. This would require an additional $\$ 131,000$ in Council funding. The management team would be kept on to finish by the fall of 1987.38

These options were rejected. In January, 1987, upon taking official responsibility for planning, Blumenauer canceled the schedule and revised the plan timeline to insure completion by June, 1987. The Commissioner was uneasy about inheriting a plan which was fairly unclear, without implementation tools and with negative reviews by some in the business community. The Commissioner decided not to ask Council for additional funding. 39 Blumenauer intervened aggressively, frustrating the committee members who were not consulted prior to the truncated end. Work had to be competed by May 1, 1987. A five week public review process began at the end of February. Four workshops and two hearings were held in this period. By this time, support for the plan had worn thin. The Oregonian speculated that putting the committee outside the planning bureau, "slack" political oversight by Strachan, and lack of direction by a staff committed to a citizen-driven process had led to "real trouble" according to Bill Wyatt, APP. This approach could be called slack, but Strachan had intended that citizens have the latitude to develop their own plan.40 Blumenauer said that he was looking "to the political realities of trying to win public support and City Council support for a plan."41 It was forgotten that Wyatt, 
eastside business interests, Ivancie, and later Clark, Sandblast and LaCrosse had signed off on the planning process.

Extensive outreach was again cranked up for the second and last design event. The staff established a special phone line; broadcast television public service announcements; produced a live, 90 minute cable broadcast; printed 1000 buttons and bus placards; and distributed newsletters and press releases. One thousand copies of a 20 page four-color tabloid were distributed. A total of 53 presentations were made. The tabloid was designed to make background information and issue discussions understandable to the citizenry. The cover and first page were devoted to describing the legacy of the downtown plan --"one billion dollars in public and private investment and 30,000 new jobs" - and emphasizing the "citizen-driven nature of the process." 42 By April, the staff had summarized all public comments on the steering committees' proposals into a two-inch thick "Report on Public Review Period 2."43 This hectic schedule was mandated by the shortened timeline. Much information was so condensed as to be unintelligible. All of the research undertaken by staff and consultants and recommendations of the eight Functional Advisory Committees could not be digested in two sittings.

\section{THE PLANNING BUREAU TAKES CHARGE}

\section{Bureau planners who had been outsiders became solely} responsible for the Discussion Draft, the last step prior to formal consideration by the Planning Commission. Michael Harrison of the 
Portland Planning Bureau began to link the policies of the steering committee and the Functional Advisory Committee to proposals for implementation. Only those policies which could be implemented and which had a willing agent were proposed. Since the Development Commission was the city's chief implementation agency, PDC effectively co-wrote the document. By June 30, 1987 a discussion draft was complete. Again, business and citizen influentials were contacted for their opinion.

The discussion draft eliminated the mixed use district by the east bank. Housing production then depended upon Macadam, the railyards north of Union Station and Lloyd District housing zones. The Macadam district was most heavily targeted. North of Burnside human service issues were put off for further study. The eastside/industrial sanctuary controversy was also put off. The plan did provide details of a bonus system which could provide an additional $50,000,000$ square feet of floor area beyond the already existing allowances.

By November, 1987 the Planning Commission began public hearings, adopting the documents through the process of adopting or rejecting amendments from the public and individual planning commissioners. 44 The Commission called for capturing the eastbank of the Willamette but preserving the integrity of the Central Eastside Industrial Sanctuary. They did not want to take on the freeway move issue but Commissioner Joseph Angel changed from initial dislike to ardent support.45 The Planning Bureau subsequently called for a study of alternative freeway alignments. The 
Commission rejected a bid to increase the target housing goal from 5000 to 7500 upon the realization that the higher limit would require the city to make zoning decisions and develop incentives favoring housing over commercial and industrial use.

On November 23, 1987 the Planning Commission unanimously adopted the plan and forwarded it to City Council for adoption. The Planning Commission turned back last minute pressure from North of Burnside, Downtown and Eastside business interests to reconsider the limited pro-housing thrust of the plan. ${ }^{46}$ Blumenauer was on hand to salute the Planning Commission for "one of the best pieces of work that we've seen ever." ${ }^{\text {"47 }}$ Yet the four year, $\$ 1.65$ million dollar plan had sidestepped the two most controversial issues - the east bank freeway move and the location of social service agencies. Neither the steering committee nor the general public participated much in Planning Commission discussion. Indeed, the steering committee had been involuntarily retired. The City Council heard from individual property interests and owners who could now focus upon the plan's impact upon their investments.

The three basic issues faced by the Council were required housing, social service siting and reductions in development permission. The business community opposed requirements for mandatory housing at Union Station and North Macadam as "land banking." The City Club did support housing requirements. The Portland Development Commission supported required housing on property other than its own. Generally, the Council supported the compromises crafted by the Planning Commission despite continued 
opposition by Macadam interests. Reductions in building density in the Central Eastside Commercial strip were assailed as preventing property development. The general concept of restricting density, technical definitions of FAR, and specific downzonings were assailed. There were a score of these requests from all three commercial areas - Downtown, Lloyd Center and Central Eastside. The irony of the CEIC request was that industrial sanctuaries were most threatened by large-scale commercial development adjacent to industrial areas. The most powerful members of the community asked for increased commercial development rights- Jack Burns and the CEIC, the North of Burnside business interests represented by Roger Shiels, the Downtown interests represented by attorneys Steve Janik and Tim Ramis. The Council turned down almost all these requests, concentrating commercial growth in the downtown crescent and away from the Central Eastside and the residentiallyzoned strip along 1-405. The City Club unsuccessfully challenged the staff and Planning Commission decision to maintain the Central Eastside as a sanctuary from the river to SE 12th Avenue

A total of 60 amendments' by business interests were defeated by Council by the narrowest of margins. Mayor Clark, Commissioner Lindberg and Commissioner Blumenauer outvoted Commissioners Bogle and Koch three to two. Blumenauer sold the development restrictions (actually not restricting the growth of the central city per se, but confining it to the light-rail crescent - see Figure 12) as a measure of Portland's egalitarian character: "A lot more people 


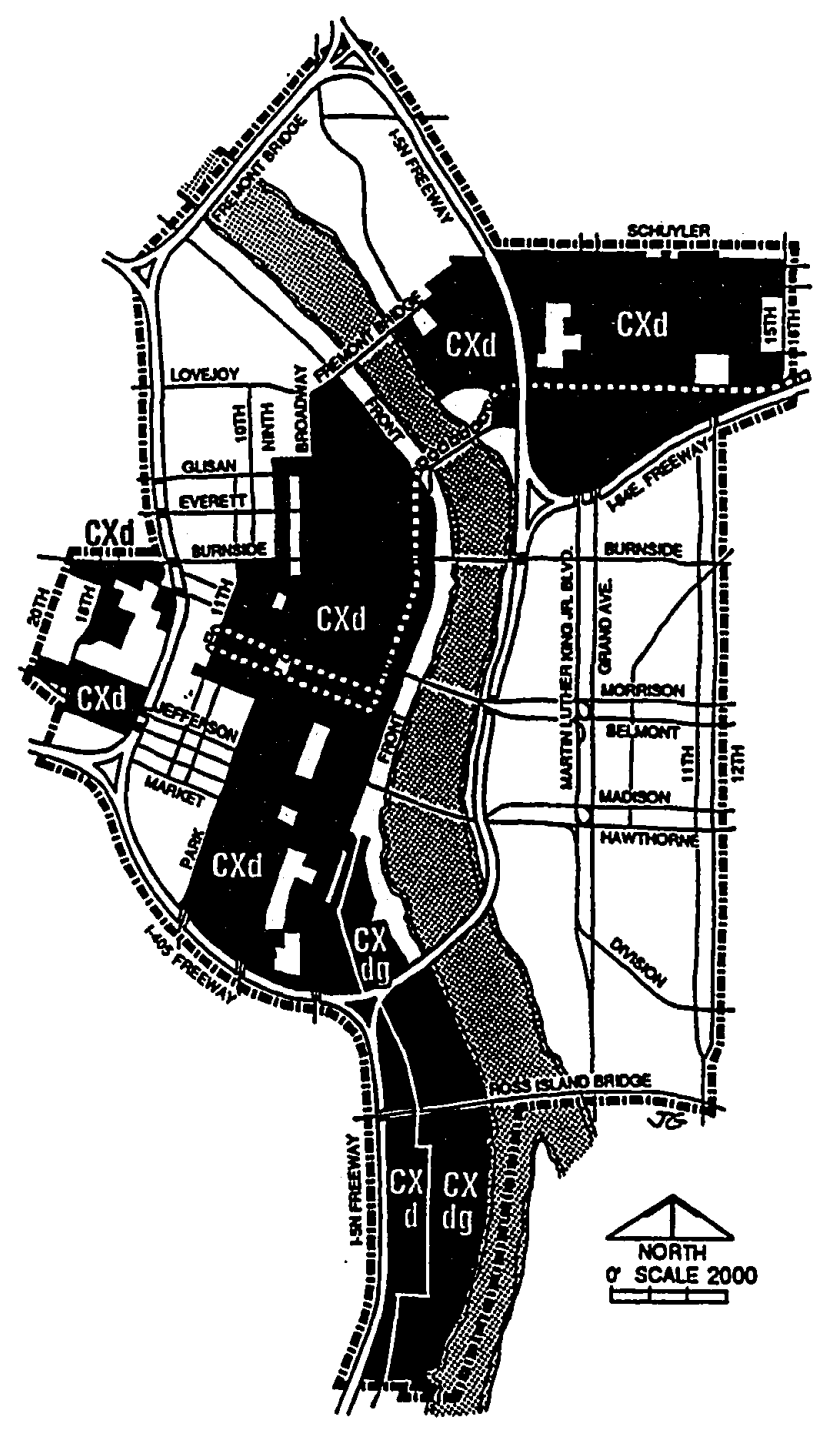

FIGURE 2-5

Commercial

Zones

LEGEND

CX Central Commercial

Figure 12. Central Commercial Arc. From City of Portland, Developer's Handbook (1992). 
can make some money instead of one or two people cleaning up and every one else waiting around for their turn." 48

The Council postponed a decision on the location of the 1-5 freeway and authorized a new study. The study suggested moving the freeway all the way to Water Street and freeing 32 acres, freeing land between the Burnside and Marquam bridges. However, City Council resolution 34473 added representatives from the Oregon Transportation Commission and the Metropolitan Service District (specifically, its regional transportation committee, the Joint Policy Advisory Committee on Transportation, JPACT, which included members from the City of Portland, and Multnomah, Clackamas and Washington Counties) to the committee along with PDC. Membership now consisted of two representatives from the Central Eastside Industrial Council, two representatives of Riverfront for People, one representative from the Planning Commission, one representative from SE Uplift, one representative from the Advisory Committee on Design and Construction for the Oregon Convention Center, and as the non-voting chair, Senator Jane Cease, also chair of the Oregon Senate Transportation Committee. This became known as the second Cease committee. 49

The Council continued the "dual-track" process of proceeding with the East Marquam project (no move, intensification of I-5 within the shorelines of the Willamette and further analysis of the ODOT proposal. The East Marquam project would be delayed until January, 1989. 
The Committee considered three alternatives - the original ODOT design, now called Alignment A; a compromise to move the freeway back from the river south of the Morrison bridge; and the most "visionary" plan to move the freeway back from the river south of the Burnside Bridge (see Figure 13). Alignment A actually magnified the freeway's visual and environmental impact upon the east bank - the freeway was widened, including the Marquam bridge and new ramps to McLoughlin (the East Marquam project). However, the project was fully funded and right-of-way already in place. The CEIC could get the needed access to I-5 soon. Alignment B relocated the freeway slightly to the east, within the ODOT right-of-way. The bridge could still be widened and the connections made to McLoughlin but the riverbank could be opened around the Hawthorne bridgehead. This project would improve the safety of traffic coming off the bridge. About 13 acres of land would be created. Eighteen businesses and 160 jobs would be lost, but redevelopment could capture from 200 to 1,700 new jobs. Alignment $C$, the proposal of the first Cease committee, relocated the freeway all the way to the railroad tracks and created 32 acres of cleared land next to the water. This project would eventually provide the best access to the CEIC. Thirty-eight businesses and $\mathbf{4 3 5}$ jobs would be displaced but up to 2,500 jobs could be recreated.50 All three alignments also had alternative versions which made for a total of six choices.

The Committee included four members who had clearly defined positions - CEIC members Vern Ryles and Bob Bouneff were opposed to any move. Riverfront for People members Ernie Bonner and Bob 


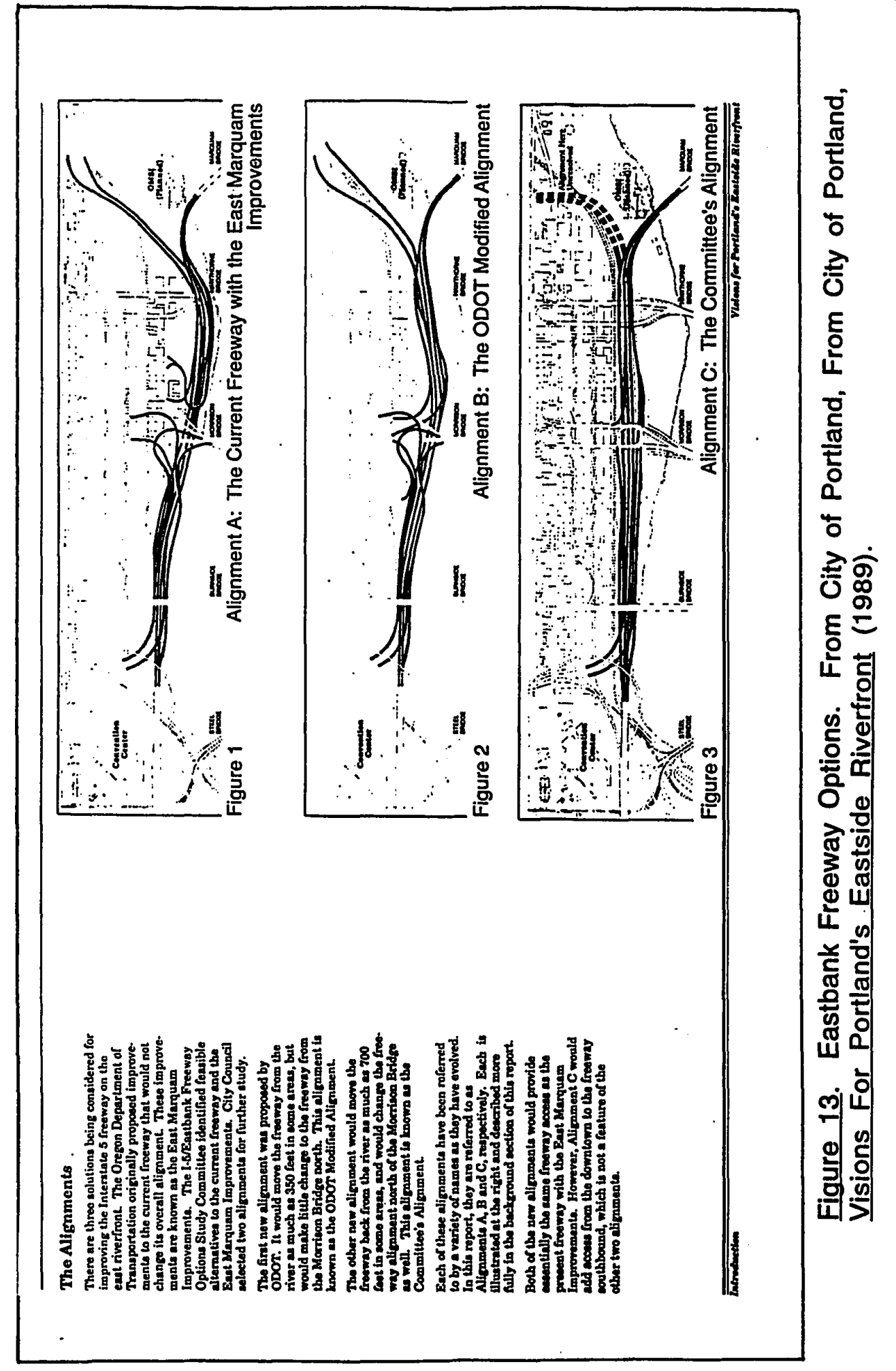


Belcher championed the original committee's work. The Committee voted 7-6 to recommend Alignment $C$. However, the method of voting became so controversial that opponents of the move could claim a split decision: The two groups had split the vote and chair Jane Cease had cast the deciding vote. The original resolutions establishing the committee had categorized her position as nonvoting. 51 The vote reflected the politics of the issue. The proponents of the move included the Riverfront for People activists, Southeast Uplift and individually prominent figures such as Planning Commissioner Joe Angel who favored Alignment C. Their City Hall champion was Commissioner Lindberg. Their vision is captured by the Oregonian forum editorial penned by Commissioner Lindberg:

The citizens of Portland are facing one of the most critical development decisions for the close of this century. We can change the face of Portland forever. We can expand both the aesthetic and economic potential of the inner Eastside. The Willamette River is ours. We can manifest the bold vision and decisive leadership necessary to seize a great opportunity or, we can allow our children's rightful inheritance to slip through our fingers.....

United, we can relocate the freeway and create a profound civic legacy for the 21st century. We need only recognize this golden opportunity in our history and exercise the stewardship our predecessors expected and our descendants deserve., 52

The no votes included the two Central Eastside members, the suburban interests and PDC. Although Commissioner Blumenauer did not vote, it was clear that he was the dominant force who presented 
the 1-5 move as a threat to the westside expansion of the light rail system.

It is true that as a public officeholder l've had occasion to lament the lack of vision of my predecessors. However, I am faced more often with the painful and expensive consequences of our city's failure to identify the resources need to carry out a vision. Mentally ill people roam our street after being deinstitutionalized without proper care available in our community. Our exciting Performing Arts. Center was built and opened without adequate money for operation and as a result is in a constant crisis.

The priorities and programs that the council has identified may lack the emotional power or the media magic of a proposal like moving the eastbank freeway. They are, however, the result of careful consideration of how best to build on our strengths and correct our weaknesses in order to improve all of Portland. Most important of all, they continue the city's traditions of tying our visions to specific tasks we are capable of achieving. 53

On March 28, 1989 the last decision of the Central City Plan was made at a press conference. After a trip on the light rail line to display it to Rep. William Lehman, (D-Fla.) chairman of the transportation subcommittee of the Housing Appropriations Committee, Mayor Bud Clark announced that he would opposed the 1-5 move. "Moving the east-bank (freeway) would cut into the funding and political punch we would use to get more MAX lines out to Washington County and elsewhere in the region."54 Both Commissioners Koch and Bogle agreed that moving the freeway would be nice but impractical. Commissioner Bogle had been represented as "keeping an open mind". A Council majority could 
have been Lindberg, Bogle and Clark.55 The main force behind the turn down was Commissioner Blumenauer, who feared to disturb the city/suburb compromise on metropolitan light rail. Suburban interests, Metro, the big-league politicians back in Washington, D.C. did not think that Portland could swing both56. In the final analysis, continued expansion of the downtown into the Central City "crescent" overrode the vision of joining East Portland across the Willamette with downtown. 57

!n this author's opinion, the greatest success of the plan had been in creating a "Central City" core better equipped to meet the challenge of the suburbs. There was strong business support in general for expansion to the eastside to directly compete with the suburbs through the expansion of the Lloyd District. There was also strong support for the light rail link to the west, north and southern suburbs. Also, there was continued consensus that livability was a key marketing tool for the city.

The great visible failure was the lack of resolve to zone and develop vast riverfront areas north and south of the downtown with housing and to allow the market to bring mixed uses to the riverbank part of the eastside industrial sanctuary. The Planning Commission was swayed by PDC's market data approach rather than persuaded by visionaries such as Crandall. The Central Eastside could not be ignored without political cost. The other non-decision - spending $\$ 60$ million on $1-5$ improvements without moving it - was precipitated by the decision to invite regional interests to pass 
judgment. This decision was made despite the physical practicality of the move.

\section{PLANNING OUTCOMES}

The interplay of redevelopment opportunities and business, citizen and bureaucratic interests lead to differing planning outcomes in each district (see Figure 14):

\section{Downtown}

Downtown experienced the least change because the status quo was desired by all. The Central City Plan fine tuned the last decade's experience in a series of trade-offs. For example, height was fixed in exchange for a hefty increase in floor area bonuses. The various land interests attempted to liberalize zoning regulations, but lost their bid at Council when these changes threatened the concept of development along a light-rail crescent. Those properties along the crescent received greater development potential.

\section{North of Burnside}

The original Downtown Plan had been ambivalent about this area. Almost by default, the area had become increasingly "blighted" as alternatives for SRO housing such as the Lownsdale district of south downtown disappeared. The 1981 North of Burnside study actually reduced development potential and promoted a social service/low-income sanctuary parallel to the industrial sanctuary. The demand of PDC to reverse this direction was entirely successful 


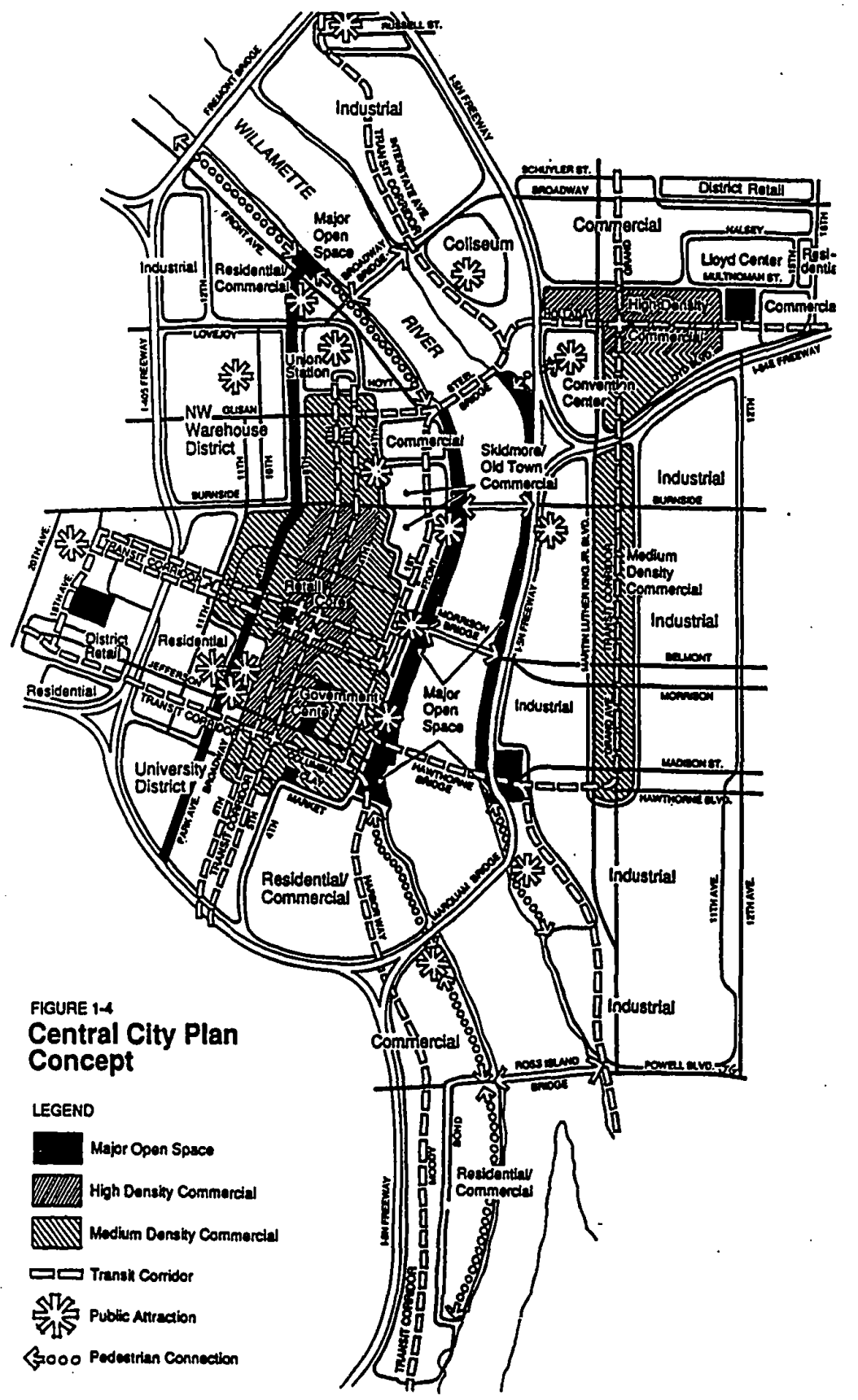

Figure 14. Central City Plan Concept. From City of Portland, Developer's Handbook (1992). 
in changing official disposition. The only obstacle to a rout of the agencies and their clients was the Clark-Shiels agreement which traded a limit on shelter beds for sufferance of the existing agencies. (Refer to Chapter VI for an extended discussion of the North of Burnside area.)

\section{Lloyd District}

Lloyd District planning was non-controversial as the dominant corporation, Pacific Development Incorporated (an arm of PP\&L electric utility) cooperated in a first-generation plan. Bill Scott, director of marketing at the time, had helped direct the Downtown Plan effort under Mayor Goldschmidt. Conflict was postponed until the eventual consideration of expansion of downtown parking restrictions to the eastside (under way by 1992).

\section{Northwest Triangle and Macadam}

The plan generally confirmed the wishes of the major property owners to transition away from obsolete industrial functions. Land owners and their representatives resisted draft plan requirements for housing. Housing activists and the Bureau of Planning wished to mandate housing; the land owners and PDC resisted restrictions on redevelopment. Eventually a compromise allowed master planning and postponement of the housing requirement. In these districts, owners' market perceptions counted the most. Investors viewed housing as a more promising market by 1992 . In this new climate, public and private interests coincide. The city's mechanisms dovetail perfectly with private investment. 


\section{Central Eastside}

It is in the Central Eastside that the conflict was greatest and clearly distinct demands put upon decision-makers. Here, vision clashed with pragmatism - the Downtown Plan's vision of a pedestrian, post-industrial environment clashed with the demands of rail and truck-dependent industry. The post-industrial vision was clearly articulated by the Urban Design Advisory Team. The vision was adopted in modified form by the Citizen Steering Committee and when dropped by Blumenauer's team, championed by some members of the Planning Commission and finally by an ad hoc group. Finally, pragmatism won out. The city establishment with the notable exception of Commissioner Lindberg and Planning Director Norm Abbott responded to the concerns of PDC and the Central Eastside Industrial Council.

\section{CONCLUSION}

This chapter has sketched the successful expansion of the west side urban regime throughout the core. City structures for promoting and shaping growth are in place throughout the core through the expansion of west side zoning and public investment in the urban renewal districts north of Burnside and in the Lloyd District. Portland has a sophisticated regime which understands the mass transit/density connections and which values quality-of-life amenities. But activists' demands are blunted.

The attempt to understand how the kaleidoscope of interests and institutions came together led us to ask three research 
questions in the previous chapter. Is the urban regime in control of the discussion and able to convert activists' demands? Does a community-wide acceptance of economic development arguments, such as Peterson's redefinition of pro-growth strategies as strategies in the public interest, cement that control? Can activists circumvent that control by getting successful initiatives on the ballot? Figure 15 provides responses to those questions for each phase of the Central City Plan.

The CCP reiterative and citizen-driven process created uncertainty for the urban regime. Commissioner Strachan and her supporters came from an activist tradition interested in traditional neighborhoods, affordable housing and social services. This interest in social policy did not fit well with the redevelopment bias of most downtown interests. Consultants alluded to tough choices between maintenance of the status quo and redevelopment at the beginning of the plan process, but these difficulties were expected to be resolved in the reiterative process. Again, this process created great complexity which had been avoided in the Downtown Plan process. Dean Gisvold, Chair of the Citizens Advisory Committee, had engaged citizens in negotiations but in a goal oriented, step-by step process.

Strachan's alternative process was created partly from necessity - by-passing Ivancie and Sandblast - and partly from a true desire to create a visionary re-iterative process. The citizendriven element of the plan created a credible but temporary platform for alternative activist positions. Activists could argue that Design Event One showed that the public supported east bank development 


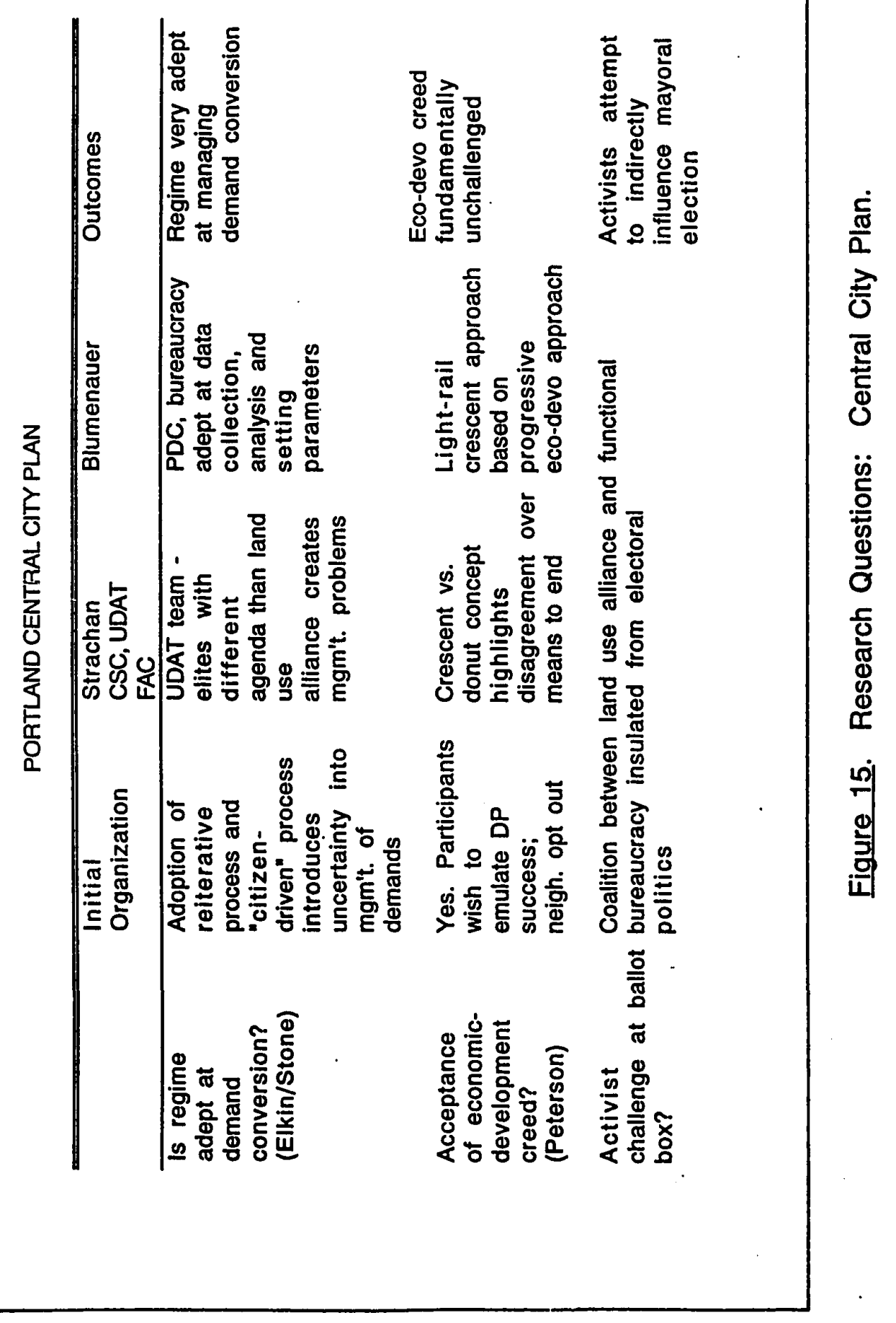


across from downtown (the donut concept). Design Event One findings created an alternative popular "vote."

Membership in the Citizen Steering Committee was based upon a "pluralist" approach which confused representation of multiple interests with dispersed influence. That is, two-fers and three-fers tried to vote on the basis of two or three constituencies geographic district, institution/business, or cause - rather than an overall appreciation of the public interest. This approach negated the complex citizen participation process. CSC members represented interests. CSC members could not take seriously the wishes of the "10,000" Portlanders who attended one of the Design Events. Two years into the plan, media events and iterative design workshops began to pale. The varied interests were not able to reach consensus on issues. There was increasing disenchantment with the plan. Plan designers were process oriented. The business community and city agencies were product oriented. Simply put, entrepreneurial urban regimes want product, not process. As the plan's process orientation created complexity, influentials became frustrated with the plan's inability to deliver. Finally, Strachan's defeat allowed the product-oriented faction to wrap up the plan. But the conflict over 1-5 and social service issues could not be massaged. Strachan's "citizen-driven" planning process allowed some dissidents to contest status quo decisions in the cause of "vision."

The entire community, including activists, accepted the basic need for growth in the core. Activists differed from the urban 
regime only in means vs. ends. Portland activists did not question the dominant role for downtown. Portland warmed to Strachan's call to update the Downtown Plan because the economic position of the core was threatened by continued regional growth. The city could no longer rely on momentum to maintain the center. The Downtown Plan had been a success. The urban regime viewed the Downtown Plan's model as absolutely necessary to spark further reinvestment in the core. The Downtown Plan model was one of public investment leveraging private investment. Quality of life projects such as parks and urban waterfalls had encouraged new office, retail and apartment construction in the past and would do so in the future. Investment in mass transit may have positive urban design implications but it was really valued as the best means to get office workers and shoppers into a very restricted space. The perceived success of the Downtown Plan allowed Commissioner Strachan the opportunity to outflank Mayor Ivancie, an economic development, project-oriented opponent of the city's quality-of-life liberals. Commissioner Strachan recognized that the continued threat of suburban style development and the opportunities for expansion beyond the 1-405 loop attracted the influentials who had gained from the previous Downtown Plan success. Powerful downtown business interests and the Development Commission welcomed a new planning effort. Antipathy on the part of Ivancie was overcome with the support of these influentials.

The Central City Plan also provided an opportunity to redress economic obstacles not satisfactorily resolved by the Downtown 
Plan. The conflict between North of Burnside business entrepreneurs and established big corporations and transients/social service providers had not been resolved by the 1981 North of Burnside Plan. The continued loss of housing in Lownsdale and south of Burnside had put increasing pressures on North of Burnside. (These issues are discussed in Chapter VII.) And the Downtown Plan could not have foreseen the construction of the light rail line through Lloyd District, over the Steel Bridge through North of Burnside and into the Downtown retail core. This would be the first leg of a region-wide system which would center on the core and help maintain its dominance into the next century. The complexity of incorporating eastside interests to the more established westside urban regime was reflected in the composition of the Central City Plan's Citizen Steering Committee and its inability to act as cohesively as the Downtown Plan's Citizen Committee had.

The light rail crescent approach was based on a progressive economic development approach The fundamental development opportunity for reinvestment lay along the light rail crescent from Downtown, through North of Burnside and Lloyd District. The westside urban regime accepted expansion to the crescent because it understood that the regional light rail system would not be built without the initial success of this first leg. In opposition, George Crandall, a member of the design advisory team; Commissioner Lindberg and others saw opportunity to redevelop the east bank and create a real river city focusing on the Willamette. Commissioner Blumenauer, speaking for the urban regime, saw the revitalization of 
the east bank not as the return to the river but as a noncritical amenity. Investment in the east bank might be a hindrance in the regional competition for development in the next decades. The outcome of the plan was a continuation of the status quo on the westside and south of Burnside, and redevelopment of North of Burnside, and Lloyd District as part of the light rail redevelopment crescent. The industrial sanctuary policy was abandoned in the Northwest Triangle district but retained in the Central Eastside. PDC expanded its programs to Lloyd District and the Central Eastside.

These planning outcomes represented the accommodation of the urban regime to the changing nature of regional access to downtown. Despite the mission statement's claim on vision, Portland's urban regime missed the chance to claim the Willamette.58 The decision to not move the freeway was justified by the public interest in maintaining industrial jobs in the city. But the westside urban regime had rejected compromises regarding the freeway alignment. Decisions were made on the basis of political understandings, not citizen involvement.

From the mission statement onwards, there was no consideration of the alternatives to the monocentric urban region. The Downtown Plan had established as policy that downtown growth was in the public interest of all city and regional residents. The Central City Plan redefined the center of the regional bull's-eye as a crescent from the west bank, through a redeveloped skid road to the Lloyd district. The Portland Central City Plan reflects the conflict 
between a "citizen-driven" planning process and a well-established "public-private partnership" which had directed central city development for the last decade.

The plan was never threatened by initiative nor competitive elections. The "public-private" partnership successfully expanded to include eastside interests and westside peripheral interests. The regime has proven adaptable and the stratified nature of most politics works to the regime's advantage. Growth was not perceived as contrary to quality of life. PDC not only implements development policy but also shapes policy. Activists threatened but avoided challenge in court, much less the ballot box. Dahl's description of hurdles to electoral activity are especially true in Portland where antagonists on one issue may be allies on another. Activists can only indirectly criticize the urban regime and the politicians and bureaucrats who learn to rely on the agency. 


\section{ENDNOTES}

1Despite the success of the Downtown Plan, the Plan failed to address housing and social problems north of Burnside, bring the middle-class back downtown or create a permanent, long-term solution to the parking/air quality dilemma. Dick Brainard, "Memorandum, Downtown Plan - Central City Plan Relationships," March 1, 1984.

${ }^{2}$ Michael Harrison, interview, April, 1991.

${ }^{3}$ Richard Forester, memo to Margaret D. Strachan, October 20, 1983, Dean Smith papers.

4Dean Smith, Interview, March, 1991.

5No author, "Contacts, Central City Plan" no date, Dean Smith's papers.

6 Consultant Gordon Davis noted that "business people knew that they had to deal with the public process but that the planning process would not disregard their concerns," interview, June, 1991. Gordon Davis, "Background Briefing," 1984, p. 14.

7City Council Resolution 33592, January 18, 1984.

Spencer Heinz, "Strachan to offer plan for Portland core," Oregonian January 9, 1984.

Oregonian editorial, "Back central City plan,: January 10, 1984.

Spencer Heinz, "Strachan plan for city core clears hurdle,: Oregonian January 11, 1984.

Oregonian, "Council due to consider central city plan action," January 16, 1984.

Chuck Goodmacher, "City plan raises issues," Observer, January 18, 1984.

8Pre-Planning Committee adoption of Don Barney \& Associates, "Citizen Involvement/Pre-Planning Process," February 6, 1984.

${ }^{9}$ Central City Pre-Planning Committee, City Councill Plan Adopted Planning Process, Adopted by the City Council, July 25, 1984.

10Don Barney testimony, Planning Commission hearing, June 12, 1984.

${ }^{11}$ Gordon Davis, interview, June 1991.

12Don Barney \& Associates, "Memorandum, Central City Plan Planning and Research Needs," January 3, 1985.

13Gordon Davis, Interview, June, 1991.

14Betsy Lindsay interview, June, 1991. 
Commissioner Strachan testimony to City Council, July 25, 1984. Resolution 33717, adopted that day, authorized the Pre-Planning Committee to initlate the start-up of the plan.

${ }^{15}$ Central City Pre-Planning Committee, City Council Plan Adopted Planning Process, Adopted by the City Council, July 25, 1984, p. 12.

${ }^{16}$ Central City Pre-Planning Committee, City Council Plan Adopted Planning Process, Adopted by the City Councll, July 25, 1984, 1-2. Not all objectives are listed.

17 Mike Francis, "Ambitious Central City Plan will seek to bridge," Business Journal, Week of May 7, 1984.

Gordon Oliver, "Leadership, Public Involvement Keys to Central City, Oregonian, May 10. 1984.

18 Gordon Oliver, "Public hearing scheduled on central clty plan," Oregonian, April 15. 1984. 25, 1984.

Gordon Oliver, "Committee agrees to revise 'central city' plans," Oregonian, April

Business Journal, "Central city plan steps in right direction," Week of April 30, 1984.

19 Gordon Oliver, "Citizens Sought to Help Guide Central City Plan," Oregonian, September 6, 1984. 19. 1984.

Gordon Oliver, "Committee Updates Status Central City Plan," Oregonian, September

20Donald Stastny, Citizen Steering Committee, May 8, 1985. 12, 1985.

Linda Kramer, "Visionaries try to shape future of central Portland," Oregonian May

21 Staff report, "District Workshops, Categorization by Issues," August 1, 1985.

Staff report, "Issue Statements," August 7, 1985.

22Citizen Steering Committee, Central City Plan, "Fred Meyer Charitable Trust Grant Application, Soclal Service component," July, 1984.

23 Michael Harrison, intervlew, April, 1991 and June, 1991. A sub-committeo was formed to redefine the process. R. Cary Jackson, Gary W. Madson and Shella D. Holden generally supported the status quo. Their report was never adopted.

${ }^{24}$ Central City Plan Process Subcommittee, "Central City Plan, Proposed Process Refinements," September, 1985.

Betsy Lindsay, interview, June, 1991.

Peter Fry, interview, July, 1991. 
25Dean Smith, Interview, March, 1991. 18, 1985.

${ }^{26}$ Central City Plan Steering Committee, "First Draft, Goals and Policies," November

Qregenian, "Central City Plan Panel Adopts 'Vision Statement'," October 8, 1985.

27George Crandall, interview, June, 1991 and Betsy Lindsay, interview, June, 1991.

28.Michael Harrison, interview, April, 1991 and June, 1991.

29 Norm Abbott, interview, July, 1991.

30No author, "UDAT Concept," no date.

${ }^{31}$ Portland Development Commission, "Briefing Paper 8: The City of Portland's Industrial Sanctuary Policy," April, 1986.

Robert H. Glascock, "The Industrial Sanctuary Policy: Purpose, History and Implementation," March 24, 1986.

${ }^{32}$ Oregonlan, "Steering Panel weighs Central City growth patterns," June 3, 1986.

Oregenian, "Panel favors transportation network as focus of city core." 1985.

Margaret Strachan, "Statement by Commissioner Margaret D. Strachan," May 8,

Alan R. Hayakawa, "Portland awaits Central City Plan," Oregonian November 17, 1986.

Management team staff, "Summary of CSC Comments - August 18, 1986 Work Session

${ }^{33}$ City of Portland, Oregon Central Clty Plan, "The Central City Plan, Choices for the Future...The first draft of a plan to guide growth in the heart of Portland," January, 1987, Draft Land Use Plan.

34Dean Smith, memo to Oregon Transportation Commission, September, 1986.

${ }^{35}$ Citizen Steering Committee (CSC) summary comments, August 28, 1986.

36 CSC staff, memo to Citizen Steering Committee, "Draft Conceptual Statements," October 27, 1986

CSC staff, memo to Citizen Steering Committee, "Draft Report and Recommendations concerning the Long Range Concept, Land Use Concept Plan and district Alternative.

Dean Smith, memo to Citizen Steering Committee, "Staff Report and Recommendations," November 14, 1986.

37 Michael Harrison, interview, June, 1991. 
1986.

38Norman A. Abbott, memo to Earl Blumenauer, Commissioner-elect, December 29,

39 Linda McPherson, interview, June, 1991.

40 Margaret Strachan interview, May, 1992.

${ }^{41}$ Oregonian, "Blumenauer delays review of Central City Plan, " January 8, 1987.

Qregonian, "Planning Committee members frustrated," January 19, 1991.

Qregonian, "Blumenauer prepares to act on stalled Central City Plan," January 26,

1987.

Oregonian, "Planning Committee told of holdover funds," January 28, 1991.

Qregonian, "Planning Committee agrees to revised schedule," February 10, 1987.

${ }^{42}$ City of Portland, Oregon Central City Plan, "The Central City Plan, Choices for the Future... The first draft of a plan to guide growth in the heart of Portland," January, 1987.

43public Outreach Program and Public Input CSC staff, "Report on Public Review Period 2," April, 1987.

${ }^{44}$ City of Portland Planning Bureau, Discussion Draft. Central City Plan

City of Portland Planning Bureau, "Supplemental Amendments Report for Planning Commission Review," October 22, 1987.

45 Norm Abbott, interview

46Union Station Business Community Association, letter to Portland Planning Commission, November 18, 1987.

Burns Bros., Inc. letter to Planning Commission, November 18, 1987.

Wright Runstad \& Company letter to Planning Commission, November 18, 1987.

47Portland City Planning Commission, "Minutes of the Meeting of November 23, 1987.

${ }^{48}$ Gordon Oliver, "Central City Plan adopted unanimously," March 25, 1989.

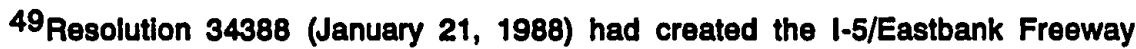
Options Study Committee. Its Final Report was issued June 27, 1988.

Resolution 34473, September 28, 1988.

50 Barney \& Worth, Inc., "I-5/Eastbank Study Update," No. 2, January, 1989.

51 James Mayer, "Eastside freeway panel favors shifting $1-5$ to east" Oregonian, January 31, 1989. 
James Mayer, "Bid to move I-5 freeway stuck in slow lane, Deciding vote by Cease called into question," Qregonian, February 23, 1989.

${ }^{52}$ Commissioner Mike Lindberg, "Chance for City to make bold statement," Qregonian Forum, March 23, 1989.

${ }^{53}$ Commissioner Earl Blumenauer, "City has other priorities more important," Oregonian Forum, March 23, 1989.

54James Mayer, "Clark stand kills I-5 move," Oregonian, March 28, 1989.

55 James Mayer, "Freeway: Is it a dream or an inspired plan?" March 12, 1989.

56 James Mayer, "Funding factors include congressional clout, local priority, Oregonian March 12, 1989.

57 Mark L. Zusman, "Road Block "Why light rail and Earl Blumenauer are standing in the way of moving the freeway," Willamette Woek, March 9-15, 1989.

$58 \mathrm{Peytl}$ and architect activists continue to return to this issue. Randy Gragg, "East Bank Blues," Qregonian, January 24, 1993. 


\section{CHAPTER IV}

\section{SEATTLE DOWNTOWN PLAN}

\section{POSTWAR OPTIMISM}

The postwar optimism and ambitions which engendered the Seattle World's Fair in 1962 also permitted the urban regime to promote a greatly expanded downtown The 1957 Comprehensive Planning and Zoning Ordinance allowed development to proceed virtually without limit. Building size was regulated by a new technique of Floor Area Ratio (FAR) limits, a maximum ratio of building floor area to site area. 1 Height restrictions were dropped and the amount of floor area allowed permitted skyscrapers everywhere regardless of impacts on surrounding development. The code divided Seattle into a compact "Central Business District" which included the major retail, financial and office, government, hotel, restaurant, entertainment and related parking areas, and the "Central Business District Periphery" which included such support services as parking, commercial uses, light manufacturing, housing, civic center, medical and institutional activities. Housing was zoned out of downtown.

\section{MONSON PLAN}

In 1958, members of the Seattle City Council and the Central Association of Seattle, a new organization of major downtown 
business interests, agreed to formulate a series of policies to "provide a workable guide for future public projects to assure that public funds available are most wisely spent; and a plan for private development which will stimulate even greater investment by private enterprise in Seattle's Central Area."2 Consultant Donald Monson, on leave from the New York Planning Commission, prepared a plan to accommodate regional growth. Monson's plan stressed improved accessibility through the development of a radial system of expressways converging on the downtown, tied together by a circumferential route around the central business district (See Figure 16). Transportation terminals would provide for transfer between automobiles and public transit.

The plan was an attempt to impose on the framework of the existing downtown the rational principles of spatial organization and circulation that had been applied to modern suburban shopping center development. In the downtown context, the area encircled by expressways would develop as a complex of glass and steel towers housing major office and retail uses. The retail core would be recreated as a mall with pedestrian links between Pike Street Market and Westlake Mall. The public space at Pike Street Market would be placed on top of a seven-level 3,000 space parking garage. Pike Street Market itself would be rebuilt or replaced in the same location. As recommended by a team of national real estate experts called "Build America Better," Skid Road would be redeveloped, including the Pioneer Square district. While Pioneer Square might be restored or rebuilt, the plan would basically level sixteen blocks, 
125

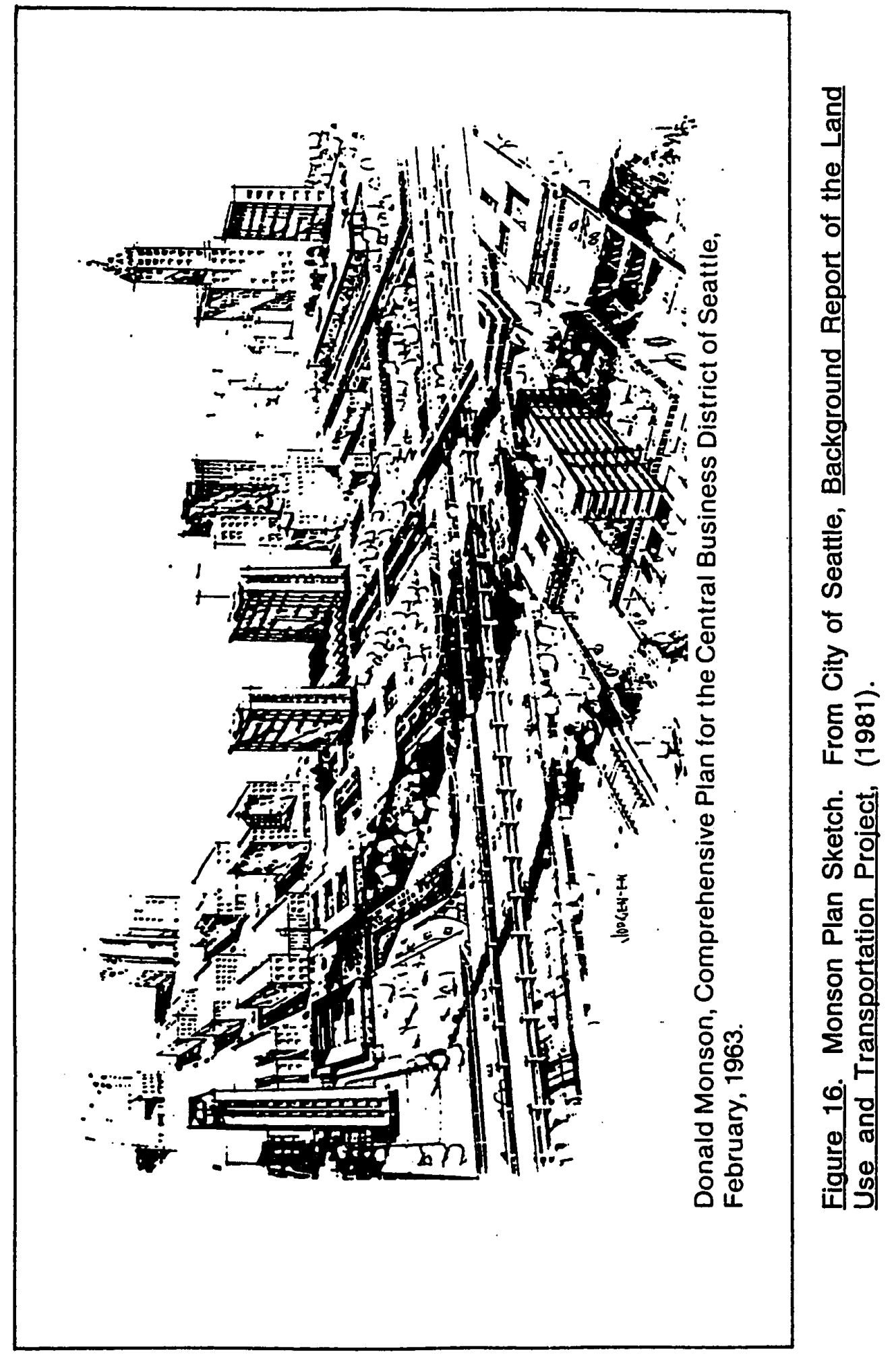


to be recombined into superblocks for major highrise office towers and parking structures.

The Monson plan has been described as a plan for both the suburbanization of Seattle and the Manhattanization of Seattle. A . prominent feature of the plan was the ringing of downtown Seattle by freeways, including two north and south connections between Alaska Way on the waterfront and 1-5 on the east edge of downtown. The plan also called for provision of an enormous parking deck and rooftop shopping center to replace Pike Street Market. As in Manhattan, floor area bonuses for plazas, setbacks and arcades were introduced to encourage tall slender buildings. In addition to large scale, publicly financed urban redevelopment projects, Monson recommended revisions to the zoning code which were inspired by the latest New York code revisions. The downtown was divided into a Metropolitan Business/Metropolitan Business Expansion zone suited to a concentrated retail shopping area, and a Metropolitan Commercial zone for offices and services. Residences were not allowed in the Central Business District because mixed uses were not promoted in the absence of schools or community facilities. While Monson recommended base floor area ratios with specific maximum floor area incentives for specific districts, the revised 1965 Comprehensive Zoning Ordinance, created to carry out these recommendations, established a uniform FAR limit of ten to one (10:1) throughout downtown with no ceiling for maximum attainable bonus floor area and, therefore, no height limit. Bonus allowances were as follows: plaza, an additional ten square feet of bonused 
office or commercial floor area for every square foot of plaza; shopping plaza 14:1; arcade, 6:1; and voluntary building setbacks, $6: 1$. The ordinance projected that a typical half-block project would contain just under 500,000 sq. ft. gross floor area and be about 47 stories in height. (The average Seattle half block project would be as big as the biggest buildings ever built in Portland.)

Seattle was thrown wide open for nearly unlimited growth. Furthermore, the new zoning disrupted traditional building/street relationships. No specifications were made within zones to delineate where certain bonus provisions would be most appropriate. Without direction, there was little hope that amenities like arcades would be provided by individual private developments in such a way that a continuous integrated system would evolve over time. The tall tower set back from the street by a landscaped plaza became the standard architectural response to the new zoning formula. Buildings stood aloof, separated from their surroundings from each other, unconnected by the envisioned pedestrian malls.

During the years that followed the code revisions, office construction boomed. New office towers were of a completely new scale for downtown, representing the physical consequences of the new zoning regulations. An unprecedented demand for office space, and a building technology that virtually removed any restrictions on building size allowed office towers on a New York scale.

This vision of a sanitized, efficient central city was not shared by all of Seattle. In the 1970s backlash described in Chapter II, voters succeeded in halting urban clearance projects. In 1970, 
Pioneer Square was brought under the protection of a municipal ordinance establishing it as Seattle's first historic district. In 1972, the voters removed additional freeway links from the Comprehensive Plan. In 1973, the seven acre Pike Place Market Historic District was established by referendum and put under the protection of the Landmarks Board. Voters had upset the New Yorkinspired planning system of downtown businessmen, City Hall politicians and staff. Planners responded to the electorate by proposing the Downtown Concept Plan, similar to Portland's Downtown Plan. The plan proposed to refocus the downtown transportation retwork on a Third Avenue transit/pedestrian spine. Parking would be funneled to the periphery and prohibited in the core. This concept quickly failed due to lack of support from the downtown community. The business community could veto any proposal it disliked.

In response to the confusion created by the public rejection of key aspects of the Monson Plan and business rejection of the Downtown Concept Plan, the Municipal League, CHECC (Choose an Effective City Council), and the League of Women Voters persuaded the city to create a community-wide commission on urban policy. The Seattle 2000 Commission established 12 task forces: community; downtown; economy and economic security; education; environment; government and citizen participation; housing; law and justice; recreation and the arts; social and health services; social justice and human resources; and transportation, utilities, and new technologies. These 12 sets of policies were formulated by an 
Executive Board, twelve task forces and 21 discussion groups. Approximately 2000 citizens participated. The downtown task force proposed a downtown in many ways similar to the vision being generated in Portland. Downtown would be redeveloped in a way that . was "non-uniform, with different parts having distinctly different densities, functions and characters (see Figure 17)." This goal maintained the traditional vision of a downtown which was preeminent in the Puget Sound region and provided a psychological center as well. The downtown would continue to grow yet maintain and strengthen in character despite the increasing competition for land: "It is important to recognize that office buildings can often pay a higher price for land, driving land prices beyond the range for cultural or recreational uses. As a result, care must be taken in the recruitment of new headquarters not to sacrifice other priority uses for downtown land. 3" The downtown task force also called for downtown housing, a pedestrian-oriented downtown and excellence in urban design.

Although the Council adopted the Goals for 2000,4 little work was done to implement these recommendations. A Comprehensive Plan process was begun but targeted the neighborhoods first. In the next decade, the effort reached downtown This phase was named the Land Use and Transportation Plan, to be addressed next.

\section{LAND USE AND TRANSPORTATION PLAN (LUTP)}

By the time the Land Use and Transportation Plan for Downtown Seattle was adopted by Council Resolution 27281 on 


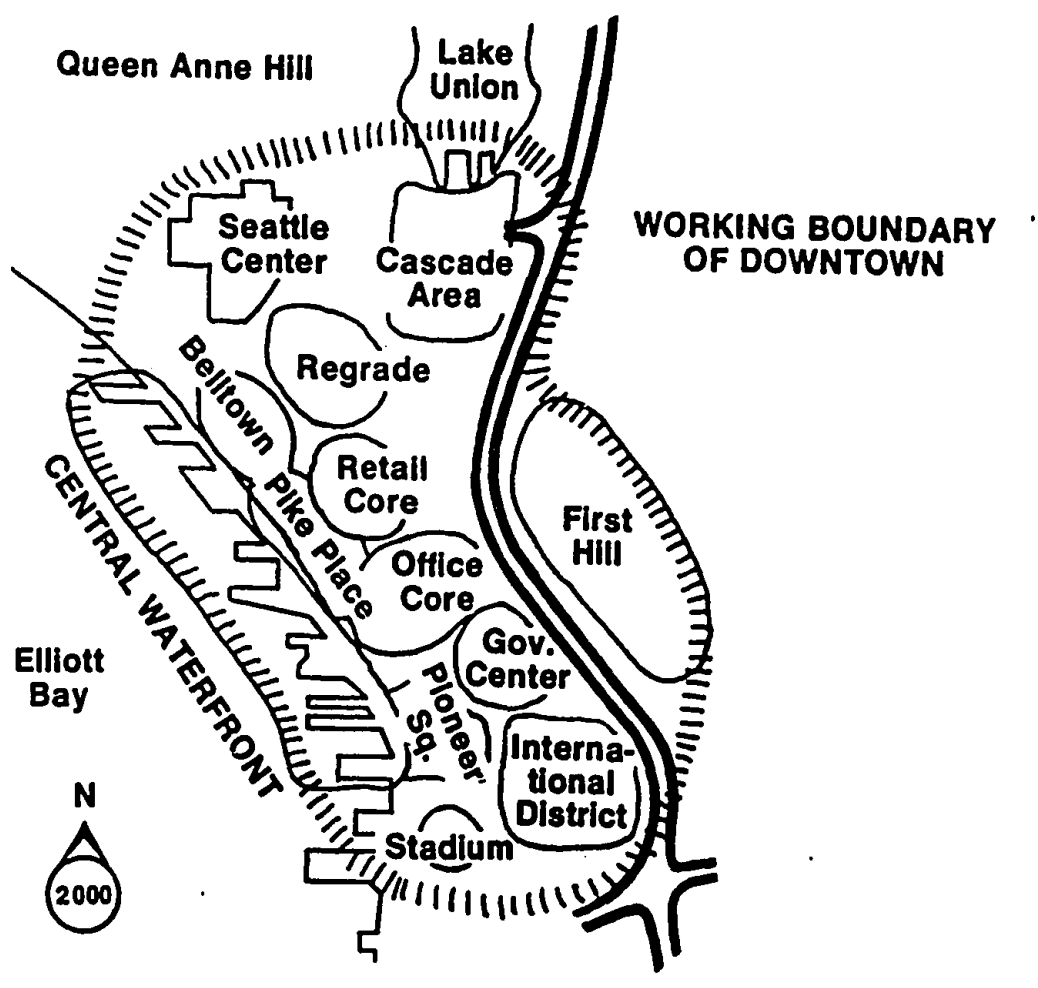

Figure 17. Seattle 2000 Downtown Areas. From City of Seattle, Goals for Seattle, Study Area of Seattle 2000 Downtown Task Force (1973). 
June 10, 1985, planners, politicians and the public had participated in an exhaustive four year process. 5 In March, 1981, the Mayor's Office of Policy and Evaluation issued the Background Report of the Downtown Land Use and

Transportation Project as a resource document "to give people wishing to participate in the downtown planning effort the basic information and analysis needed to develop alternatives for land use and transportation downtown." This document set out policy issues in five areas: transportation, natural environment, energy, housing and services, and land use and design. For each topic, a summary of Seattle history was provided, background information research by consultants summarized, and policy issues framed. The assumption that continued growth would solve problems as well as provide new challenges was the theme behind this as well as most future debates:

Growth is at the core of nearly all major issues confronting downtown Seattle. If employment in downtown doubles in the next 15 to 20 years as expected, it will affect the transportation system, the natural environment, energy resources, the housing supply and the character of downtown. ${ }^{6}$

A series of hypothetical policy questions implicitly supported continued growth but also laid the groundwork for acting to save the retail core and create additional designoriented regulations. The background report rhetorically stated a fact and then pondered a suitable planning outcome. 
The issues are quoted at length so that the reader can sense

the tone of the project:

More housing is being built in and around downtown. To what extent can downtown housing be relied upon to reduce commuter travel demand? Will people living in new downtown housing also work downtown?"

Growth improves the prospect for achieving the City's goal of more housing in and around downtown. It also makes older apartments and residential hotels in the downtown core more susceptible to redevelopment or conversion to more economic uses. Should a balance of low, medium and high income housing be sought downtown?

The zoning ordinance segregates major land uses into office, retail, service/manufacturing and residential areas. The intent of the zoning is to concentrate and intensify retail and office uses in particular. Are offices encroaching into the retail core ? Should the retail core be kept compact? Should it extend into adjacent areas along certain streets?

Seattle's Zoning Ordinance treats downtown like a flat plane without hills. The bonus system and others regulations ignore the existence of steep slopes. Without height controls, building on the lower slopes can build high to maximize views diminishing the natural topographic form and block upland views. Should zoning take topography into account? Should protection of private views be an objective of height limits?

Elements of buildings and open space which lend a human scale create a pleasant pedestrian environment. The scale and texture of building materials, sizes and spacing of windows or other openings in walls, heights of buildings or portions of buildings, street furniture and landscaping all are critical elements in determining the character of pedestrian spaces. Should these desired features be encouraged through zoning?? 
The background document left these and other rhetorical questions unanswered. However, the document provided support for the view that downtown Seattle should remain the pre-eminent center for business, government and cultural activities of the region. Activist positions that downtown housing can provide an answer to commuter snarls, that zoning tools to encourage low and middle income housing were required, that the retail core required protection, and that the 1965 zoning ordinance ignored or defeated valid urban design considerations were accepted as well. Once the background report was issued, citizens were invited to begin the public participation process. The Seattle Planning Commission issued a paper on goals, and the city conducted forums and workshops. These activities generated several "soft" or preliminary alternatives.

In August, 1981, the city issued Guidelines for Downtown Alternative Plans which served as the basis for future planning. These guidelines disallowed alternatives to core dominance. Fifteen competing alternatives were then submitted by civic interests groups. (See Figure 18 for a few alternatives.) The most influential players in the process were the Downtown Seattle Development Association (now the Seattle Downtown Association or DSA), Allied Arts, a venerable Beaux Arts group, the Sierra Club, and housing activists. Many of the Citizen's Alternative Plan initiative issues were first raised by these interests. 


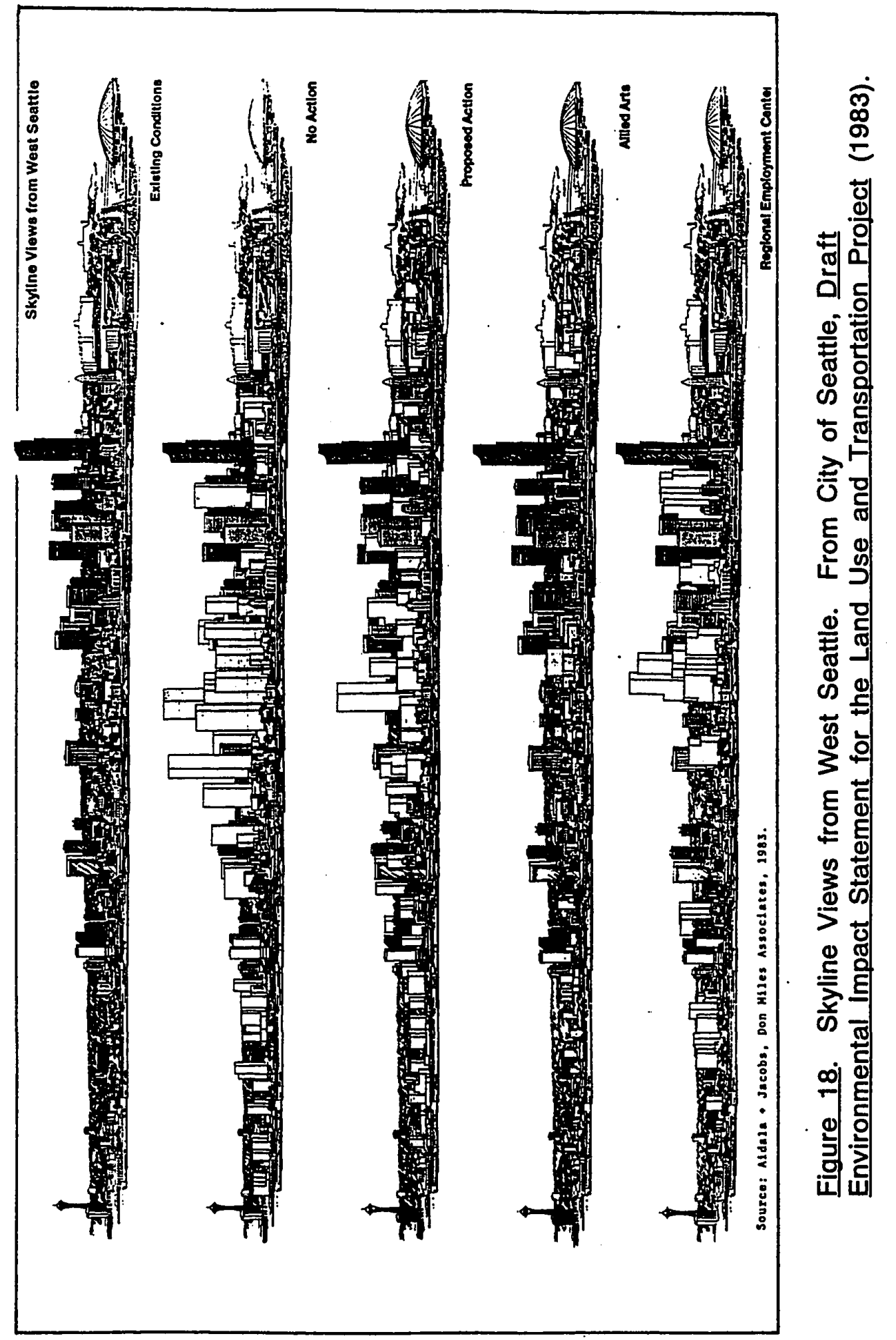


The Downtown Seattle Development Association (DSDA) stressed the value of high intensity uses in the office core. The DSDA argued that allowed density would even need to be increased in the northeast area of downtown (now the DOC-2 zone.) A mix of uses such as retail, theaters, restaurants and short-term parking would provide vitality and fill dangerous empty spaces. This mix would be encouraged through floor area incentives in and near the retail core. The DSDA was willing to allow incentives for amenities such as usable open space, landscaping, special sidewalk treatments, weather protection over sidewalks and plazas, interior public spaces, artwork, and preservation of landmark buildings. Housing would be promoted through zoning incentives but not on a higher priority basis than building or pedestrian amenities through the bonus system. The DSDA was supportive of altering base and incentive FAR limitations in different parts of the core and was opposed to "simplistic, blanket height limits." The DSDA was willing to acknowledge the need for "light and air," protection of historic districts, the impact on public services, and even shaping a certain city skyline but the plan should not supplant investment considerations:

Public policies which are intended to guide the intensity of development within the Downtown should recognize the effects of both the height and the bulk of buildings. Any controls on height and bulk should be based upon consideration of a number of factors, none of which is necessarily more important than any of the others To a certain extent a clustering of taller buildings in the core will also reflect the market place: high land values, 
more intensive business activity, etc. Third, building heights can accentuate natural topographic conditions, with greater heights at higher elevations. These factors are complex and interrelated and are not adequately addressed by simplistic, blanket height limits. ${ }^{8}$

The DSDA considered the proper mix of uses in the retail core to be retail and offices. Retail and restaurants would predominant at the ground floor with intensive office development at upper levels. The DSDA parking subcommittee urged that the supply of at least short term parking be substantially increased and that any attempt to promote transit or carpooling not discourage the suburban shopper. The DSDA's housing subcommittee envisioned substantial residential growth in peripheral areas of downtown; most new or rehabilitated housing would be market-rate housing.

In contrast to the DSDA, the Sierra Club Urban Committee challenged the notion that the downtown could sustain any rate of growth. The Sierra Club proposed that the city study the "desirable rate of growth" of office and retail space in downtown Seattle. Based upon a study of service costs and effect upon city revenue, a maximum yearly allowable rate of growth would be defined. Master Use Permits would be rationed and distributed according to a point system. City planners, politicians, architects, builders, retailers and citizens would define the general characteristics desirable in new downtown structures. Points would be awarded for values such as "excellence in the design of the building itself, 'humanness' of scale in terms of height or bulk, the provisions 
of on-site parkland or moderate-income housing, or how well a retail shopping complex was integrated with the office structure." $A$ housing linkage program might be required based upon a study of how many new residents would be attracted to the city by a new project. The developer might be required to build new housing units, rehabilitate existing units, donate cash to the Seattle Housing Authority or obtain low-interest financing for another housing developer. A developer would also facilitate the provision of park land in similar fashion. The Sierra Club also proposed urban design initiatives such as requirements for retail, prohibition of dead plaza space and prohibition of parking space at the ground level. Height limits were set at 10 stories in the retail core, and 28 to 38 stories in the office core. The retail core would be expanded. Parking would be cut in half over the next 20 years and be devoted to short term shoppers parking.

Likewise, energy conservation would cut energy needs in half in the next 20 years.

Allied Arts challenged the Monson notion that the city become a high rise city, subject to office building speculation in the retail core as well. The Allied Arts Plan proposed a dense, low-height downtown.10 Floor area and height were greatest in the office core, tapered down toward Puget Sound, and were reduced by two-thirds in the retail core.11 In the Central Business District two to three stories of housing would be provided in the office towers with restaurants, 
hotels, and classrooms at the bases. Interior shopping malls would be prohibited. The retail core's character would be enhanced and preserved through establishment of a Special Commercial District, characterized by preservation of existing Art Deco architecture and height, bulk, texture and frontage regulations built around the existing streetscape. Lower heights in the retail core would create a sense of light and openness in the retail core. A pedestrian wedge would be created between the retail district and Pike Place Market along Stewart, Pine and Pike Streets. The alternative proposed a network of landscaped and identifiable pedestrian pathways and streets, interconnected with a series of nodes to enhance the user's awareness of the relationship of the many activity centers and facilities located downtown. Growth would be accommodated through a more intensive use of existing buildings and available land rather than concentration on a few sites.

An architecturally-oriented faction called the Citizen's Alliance for Urban Seattle (CAUSE) called for the decentralization of Seattle with multiple centers throughout the region to avoid formless regional sprawl. ${ }^{12}$ This group represented architects and urban design oriented activists outside the establishment American Institute of Architects which generally supported the development community. This ad hoc group lacked the institutional prestige of Allied Arts. A housing coalition, the Downtown Neighborhood Alliance, 
wished to retreat in general from the DSDA/planner's vision of a greater downtown. The DNA suggested that the allowed FAR be lowered to $5: 1$ and bonus FAR be restricted to housing or energy conservation. Regional transportation projects such as the 1-90 highway project or the downtown bus tunnel would be scaled down. The downtown convention center would be abandoned. Developers would pay a housing development fee and a transit impact fee as in San Francisco. A unique suggestion called for relocation assistance for displaced small businesses, guaranteed five year leases, and use restrictions which required neighborhood oriented uses. ${ }^{13}$ As far as this research can determine, this was the first time that a general anti-growth position was taken by any Seattle organization. Much of the information marshaled in the organization's manifesto, The Issue of Downtown Growth - Limits to Growth was generated by the city's requirements for environmental impact analyses of each major downtown project.

A Mayor's Advisory Group reviewed each "soft" alternative (that is, business or citizen activist proposal). 14 The advisory group did not formally approve or disapprove policies or regulations but provided advice to the mayor's office. No consensus was reached on a particular alternative. Another two years of city work to June, 1983 resulted in the Draft Land Use and Transportation Plan for Downtown Seattle. Thirty-nine civic interest groups and thirty-eight community councils participated in the review of the Draft Environmental 
Impact Statement (EIS). Their response widened the gap between the city's proposed plan and activist expectations. For example, Allied Arts applauded the proposed downtown regulations for street walls, upper level setbacks and view corridors. Yet, Allied Arts noted that the city was not fundamentally addressing the question of the economic compatibility of office and retail redevelopment with the continued existence of small businesses. Height limits were too generous, and where height limits were in place, permitted floor area would create political pressure to raise height limits. ${ }^{15}$ The planners responded that property values and rents were likely to increase regardless of the approach to growth taken. Any attempt to moderate growth downtown would send development pressures to outlying commercial areas and there small businesses would be displaced. ${ }^{16}$

The Mayor's Recommended Plan was issued in May, 1984.

The document tallied the hundreds of citizens involved; the $\mathbf{5 0}$ staff presentations concerning the Draft Land Use Plan; the nearly five hundred people who attended the public forums in September, 1983, and the one hundred people who attended a forum at Seattle Center in December, 1983.17 Yet these numbers do not prove public citizen involvement. Many discussions regarding the base FAR allowances and incentive system bonuses and details were negotiated in a series of workshops between planners, architects and representative of the Downtown Seattle Association. Market studies provided 
the rationale for negotiations over base and bonus floor area provision. 18 The Mayor's Recommended Draft reiterated the old vision of downtown as the pre-eminent commercial, governmental and cultural center. No height limit was imposed on the primary downtown office core. While the base FAR remained at $10: 1$ as before, amenities such as the provision for parking, pedestrian amenities and aesthetic amenities allowed an increase to 15:1 FAR. An additional 5:1 FAR could be earned by providing housing. But this was an incentive system rather than requirements as originally required. The draft did significantly advance planners' desire to downzone the retail core. Staff gained support from the Allied Arts proposal. Projects in the retail core would have to include a performing arts center or a major department store to approach office core project magnitude. The retail core was kept at its original proposed size mid-way between the Allied Arts proposal and that of the DSA.

Paul Kraabel, chair of the Seattle City Council Urban Redevelopment Committee, negotiated the plan between property owners, planners and consultants and homeless advocates. Staff prepared notebooks which contained details of all proposals surviving to this stage. The committee voted on each amendment. For example, the Committee refused to impose a height limit on the Downtown Office Core-1. City Planners calculated that floor area regulations would limit 
heights to approximately 700 feet but the Committee refused to set a definite height limit.19

\section{PLAN POLICIES}

The 1985 Land Use and Transportation Plan ratified many of the decisions of the last decades restricting speculation in the periphery of downtown - Denny Regrade, Pike Street Market, Pioneer Square, the International District - while allowing expansion in the core (see Figure 19). Those policies most concerned with return on investment called for the regional preeminence of downtown and expanded office, commercial and retail trade. Those policies highlighting the new concern for "use" values concerned urban form and housing and neighborhoods. The document attempted to reconcile these conflicting values by promoting a "preeminent regional center" but allowing only "reasonable" development which could be serviced and which met vague policies.

\section{Housing}

As a result of pressure from low-income advocates, the city promised to maintain low-income housing. Previously, planners had been concerned about the gap between lowincome and luxury housing and focused on providing marketrate middle-income housing with floor area bonus incentives. LUTP pledged the city to maintain the existing number of low- 


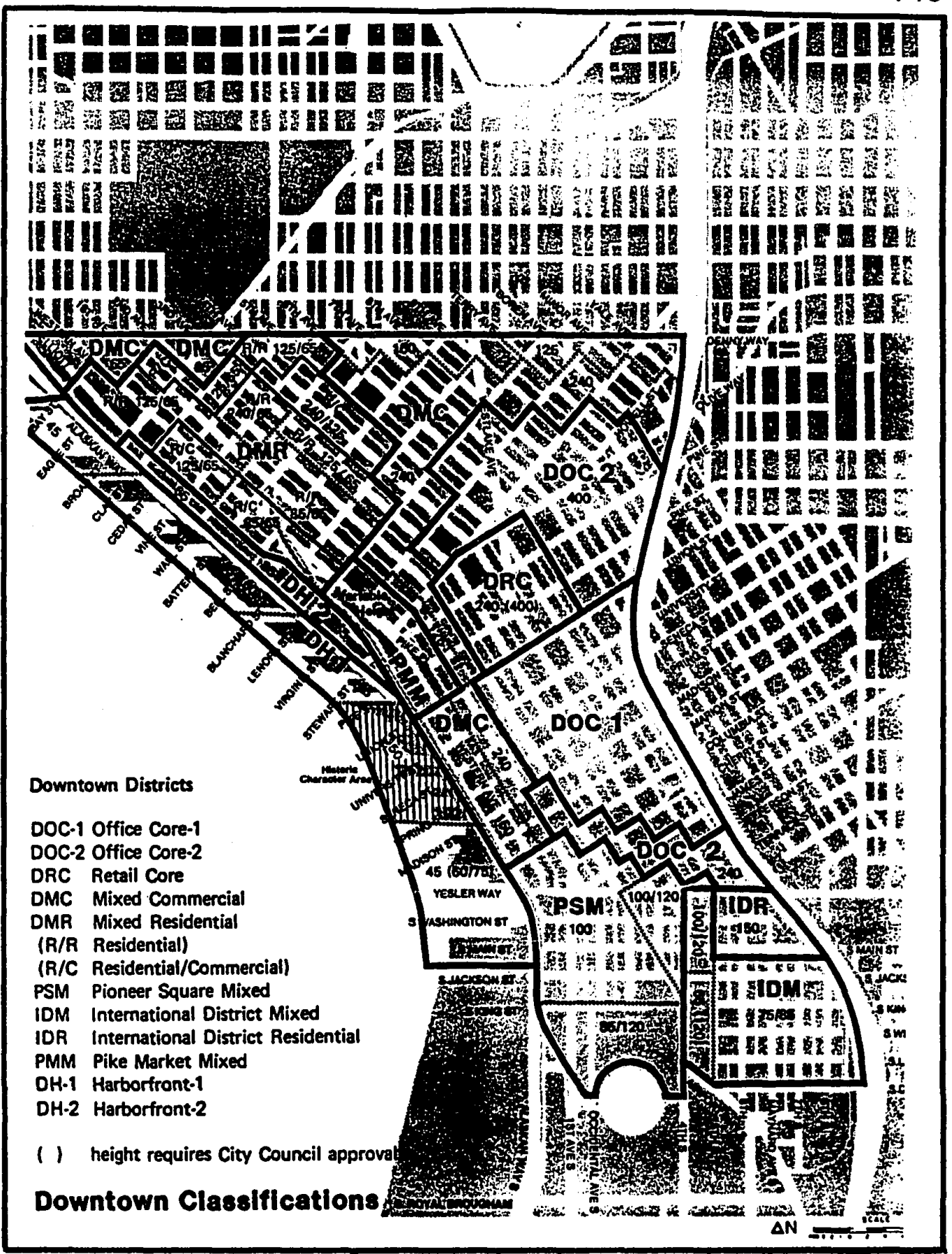

Figure 19. Downtown Classifications and Heights. City of Seattle, Land Use and Transportation Plan (1985). 
income units and keep housing affordable. As Chapter VIII illustrates, housing displacement was one area where promises could not be kept; the activist community attacked the city/development community emphasis on voluntary provision of housing for the displaced.

\section{Urban Design}

Allied Arts had championed urban design requirements to address the failures resulting from the 1965 Comprehensive zoning regulations. Allied Arts sought design-oriented development regulations and also pushed for limiting density and for preserving historic structures. However, developer and city antagonism prevented the formation of an urban design commission despite policies calling for enhancement of the remaining varied character of different districts in Seattle.

\section{Arts}

The arts community emphasized the economic benefit to the downtown if provisions were made to allow major arts institutions a chance to relocate downtown. A sizable floor area incentive bonus was created for a performing arts center. Because the Seattle Art Museum could only be built as a legally vested project, Seattle City Council allowed more liberal vesting than otherwise warranted in the transition from the old to new zoning. Several large projects were vested, creating examples for activist arguments. 
Office and Commercial Concentration

With the exception of the Sierra Club there was general consensus on the need to have a high-density commercial core. Much of the "mainstream" controversy centered on the First and Second Avenue corridors. The development community wished for higher densities than ultimately allowed, but lower densities worked better in revitalizing existing structures. The lack of height limits in the Downtown Office Core-1 was not an issue. Traffic capability was conceived only in terms of immediate infrastructure; that the bus tunnel would efficiently get traffic to the margin of downtown but no farther was deemed sufficient.

\section{Retail}

Planners wanted strong protection for the retail area, especially key sites surrounding the existing department stores. Staff wanted lower floor area allowances than eventually allowed; the DSDA wanted retail zoning in a smaller area than originally mapped.

\section{Peripheral Residential Areas}

The plan provided significant protection for peripheral areas such as the International District and Denny Regrade. Previously considered light manufacturing districts, or areas ripe for redevelopment, these districts were now protected by strict zoning regulations in exchange for significantly restricting commercial uses elsewhere in the core. This left 
Pioneer Square without a public commitment to maintain lowincome housing.

The mayor's proposed housing linkage program was quickly abandoned after an initial proposal in 1981 due to developer opposition. When the housing preservation ordinance was declared invalid by the court in 1985, the incentive provisions became the only zoning tool available.

\section{Incentives}

More than any other zoning device, the adoption of an incentive system requires a balancing of private and public interests. The choice of bonusable public benefits, the establishment of minimum "as of-right" floor area, the ratio of incentive floor area to public benefit feature, and the maximum incentive floor area ceiling for different amenities reflect the balance of interests in a community. The "equivalent land value method" was used by the city to establish the amount of incentive floor area permitted for each public benefit feature.20 The cost of each feature to be provided was equated to the cost of land per square foot in each land use district. the plan trade-offs assumed that bonusable feature must always be a more lucrative route for the developer to be an incentive.

The Plan provided for a base FAR of 10 with allowances for a FAR as great as 20:1 with the housing bonus or 15:1 with amenity bonuses. Amenity bonuses included items which were likely to be provided such as urban plazas, roof top gardens and 
public atriums. There was no height limit in the Downtown Office Core-1. The Downtown Office Core-2 was more restrictive with a base FAR of $8: 1$, and FAR of $14: 1$ with housing and 11:1 with only public amenities. Height limits ranged from 240 to 400 feet.

The Downtown Retail Core also allowed tall buildings of 240 to 400 feet, considerably larger than the existing two to seven story buildings in the retail core. A maximum of 14:1 FAR could be built if a project included a major department store or performing arts theater. Bonuses were "tiered" so that amenity features could be provided first to gain additional floor area above the base floor area permitted. Housing could then begin to substitute for any amenity and became the sole option above an arbitrary limit. For example in the Downtown Office Core-1 the following tiered density schedule applied:

FAR 10:1 - 13:1 Amenity Bonus Features only

FAR 13:1 -15:1 Amenity or Housing Bonus Features

FAR 15:1 -20:1 Housing Bonus Feature only

The following chart indicates the varying levels of permitted and bonusable floor recommended at various phases of the plan. (Activist proposals were incorporated into the CAP proposal.) 


\begin{tabular}{|c|c|c|c|c|}
\hline & & $\begin{array}{l}\text { TABLE VI } \\
\text { TP DENSITY }\end{array}$ & MITS & \\
\hline & & rime Office & rea & \\
\hline Plan & Base & Amenity & Housing & Housing TDR \\
\hline & & Bonus & Bonus/TDR & \\
\hline 1965 & 10 & 17.3 & 17.3 & 17.3 \\
\hline Staff 1983 & $10(12)^{b}$ & $16(18)^{b}$ & $18(20)^{b}$ & - \\
\hline Mayor 1984 & 10 & 15 & $15^{a}$ & 20 \\
\hline LUTP 1985 & 10 & 15 & 20 & - \\
\hline CAP 1989 & 5 & 7 & 10 & 14 \\
\hline & & ondary Offic & Area & \\
\hline Plan & Base & Amenity & Housing & Housing TDR \\
\hline & & Bonus & Bonus/TDR & \\
\hline 1965 & 10 & 17.3 & 17.3 & 17.3 \\
\hline Staff 1983 & $8(10)^{b}$ & $12(14)^{b}$ & $14(16)^{b}$ & - \\
\hline Mayor 1984 & 8 & 11 & 14 & - \\
\hline LUTP 1985 & 8 & 11 & 14 & 10 \\
\hline CAP 1989 & 4 & 6 & 8 & 10 \\
\hline
\end{tabular}




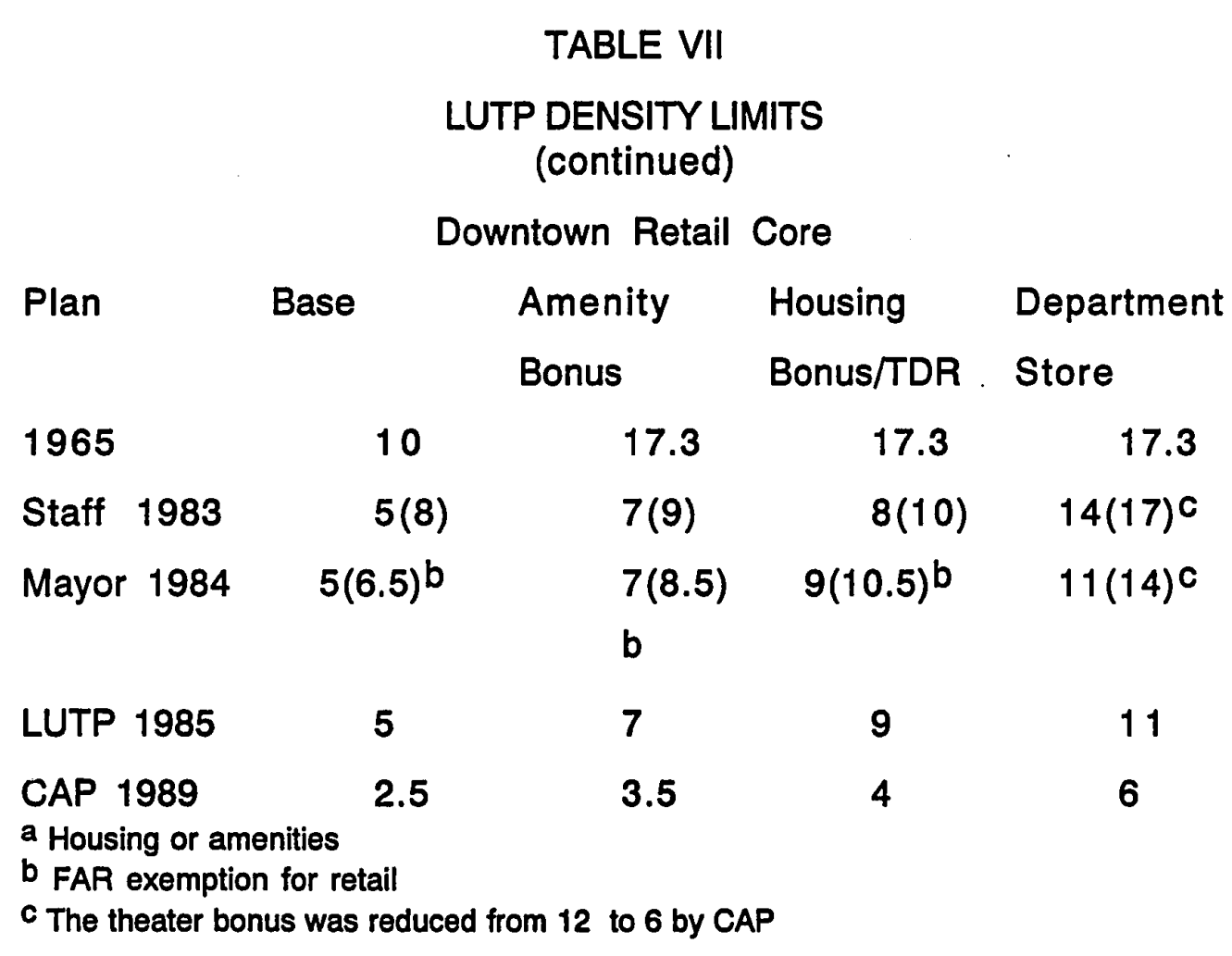

Council adoption of the Land Use and Transportation Plan was anticlimactic. Several developers spoke in favor of the plan, indicating that the city had successfully negotiated with the development community. The staff's greatest goal was simply to get the plan adopted, while the citizenry had been lost in the technical discussions of office construction costs associated with the downtown building and density studies. The public had expended much energy in disputing the Draft EIS. Paul Kraabel's council workshops made decisions without much input from city planners. Allied Arts acquiesced in the compromises and the Sierra Club's opposition seemed insignificant. Vesting new projects was a 
political decision. Although technical analyses were done by both city planners and attorneys, liberal vesting regulations were necessary if the Convention Center and Westlake Mall/Seattle Art Museum were to be built. The vesting of several projects meant that office towers continued to rise at the same time as work progressed on the Third Avenue bus tunnel and the Convention Center. Over four million square feet of office space was under construction in 1988.

\section{CITIZENS' ALTERNATIVE PLAN}

The decision to vest these office projects, including Seattle Art Museum/Westlake, ultimately brought the issue of growth and the form of growth to the entire citizenry. The Citizens' Alternative Plan coalition represented the coalescence of environmental, neighborhood and social activists' concerns that the political status quo favored downtown interests at the expense of their own concerns: namely, growth, housing, neighborhood commercial district viability, traffic and air pollution, urban design and taxes. In 1987, these interests came together in Vision Seattle, a grassroots political organization. In July, 1987 two dozen neighborhood activists met to discuss the lack of credible candidates opposing the incumbent City Council candidates up for election. The neighborhoods, especially the middle-class neighborhoods to the north of downtown, were appalled that Royer and the incumbent Council had forged an alliance with downtown which did not include middle-class neighborhoods: 
Mayor Charles Royer, who had campaigned a decade earlier as the champion of the neighborhoods, aligned himself most closely with the downtown business community and the Democratic Party. He allowed developers to build big skyscrapers in the center of town and bulky apartment buildings in the neighborhoods. At the same time, however, he tapped them for help in financing social programs and new housing for the poor.21

Pat Strosahl, Bill Keasler and other activists formed Vision Seattle. The new president, Pat Strosahl, had drifted away from early political activism (opposing the Vietnam war) into running the family jewelry business. He was brought back to political action by plans for a massive apartment complex down the street from his bungalow. Co-founder Bill Keasler had received a similar jolt. A computer engineer and longtime activist with the Lake Union houseboat community, he had become involved in neighborhood politics when he had learned that his landlord planned to raise moorage fees beyond his ability to pay. Keasler challenged his landlord all the way to the state Supreme Court and back to City Hall, and won. Within a year, Vision Seattle had led a successful fight to defeat Royer's $\$ 35,000,000$ plan to transform the Seattle central waterfront into what it feared would be a Seattle version of San Francisco's Fisherman's Wharf. It had also beaten a King County open space bond issue that it felt included too much money for the Seattle Aquarium and not enough for purchase of land for open space.

The Vision Seattle coalition included advocates for the poor such as the Catholic archdiocese's Tony Lee, housing activist John Fox and urban design advocates such as architect Peter Steinbrueck and attorney Margaret Pageler of Allied Arts as well as Ted Inkley of 
the Sierra Club. The Asian and minority communities, whose longtime positions of the Seattle City Council were challenged by Vision Seattle candidates, were not part of the coalition. Vision Seattle's CAP initiative became a vote of no-confidence on the urban regime which had pursued the same pro-growth policies since 1965.

The activists were given a useful example of what LUTP would allow with the construction of the Washington Mutual Tower. The tower, at 1201 Washington, was built under the new rules (see Figure 20). While the Washington Mutual tower was acclaimed for its architecture, approval of this project indicated that any tall tower could be easily built under the new system. The tower reached $700 \mathrm{ft}$. at a FAR of 19.7:1 or 1 million square feet of building. The new tower grew from 30 to 55 stories with the use of bonuses. It gained 13 stories for a $\$ 2.5$ million dollar donation for housing, two stories for excluding mechanical space, one and 1/2 stories for an atrium, two and $1 / 2$ stories for an escalator to connect Second and Third avenues, one story for day care for 22 children, two stories for an additional 15,000 square feet of retail space, two stories for a public courtyard near the Second Avenue entrance, $1 / 2$ story for a flowered terrace above the plaza, and two stories for a sculptured top. The Washington Mutual tower was estimated to generate over 1,000 vehicle trips into and out of downtown Seattle during rush hour alone and an additional 5,490 transit trips - the equivalent of 43 loaded buses. The single tower would use enough electricity to light 1,300 medium sized homes 


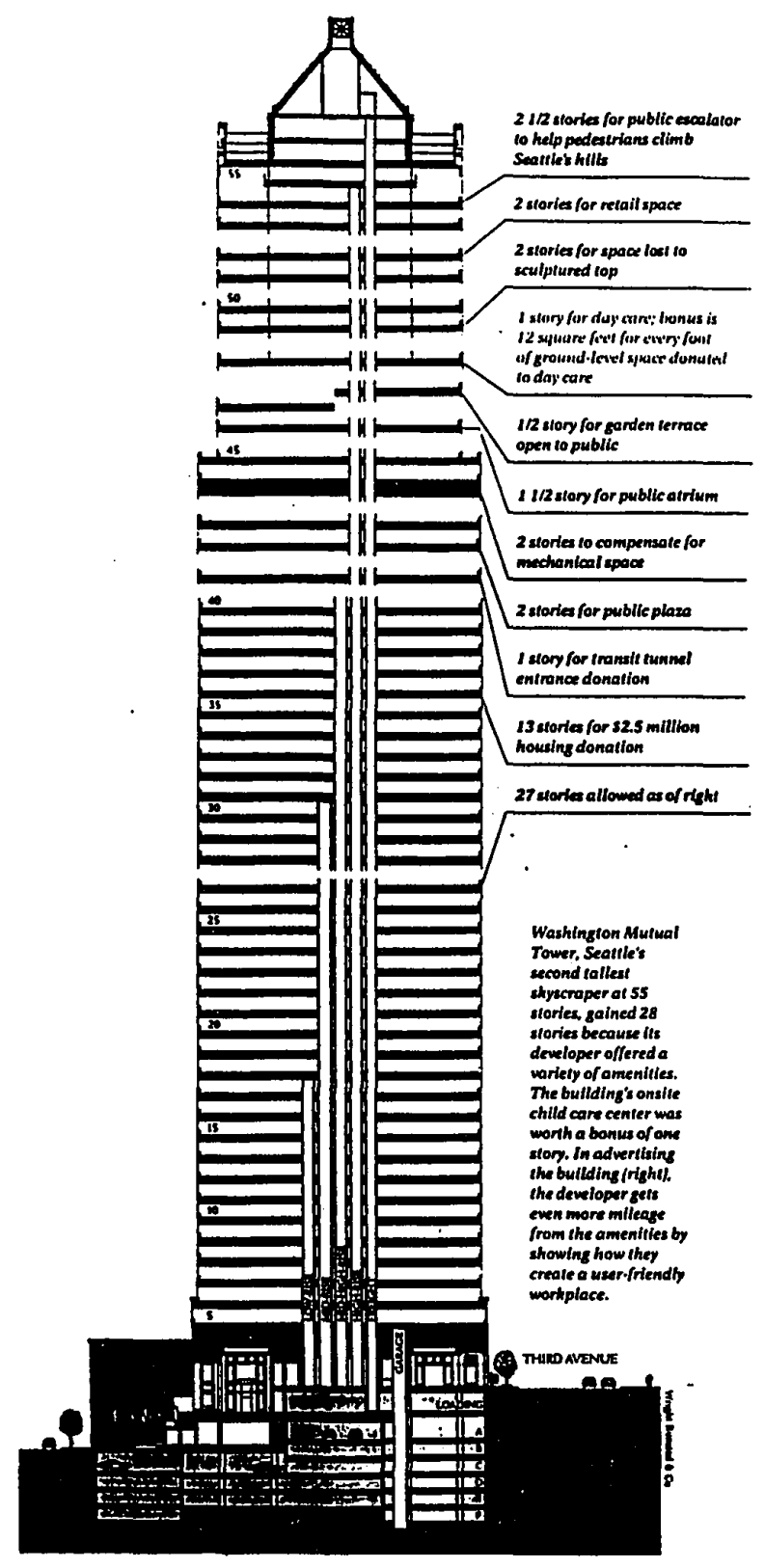

Figure 20. Washington Mutual Tower Floor Area Bonuses. From Planning Magazine, "Child Care Grows Up," May, 1989. 
increasing demand for non-hydro electricity. The project would demolish the Savoy Hotel which had 225 vacant units of low income housing. In sun-starved Seattle the tower would cast a 260,000 sq. $\mathrm{ft}$. shadow during a winter day. ${ }^{22}$

In February, 1988 Ted Inkley, on behalf of the Sierra Club, proposed that Council consider reducing the rate of growth downtown. Ted Inkley had previously written on behalf of the Sierra Club to advocate rationing development but that concept had never been taken seriously. He had also unsuccessfully opposed the intrusion of an office tower into the Westlake/retail district area as part of the group People for an Open Westlake. Council refused to reconsider the matter. The Citizens' Alternative Plan proposal was then put on the ballot and passed on May 16, 1989. Over 14,000 voters signed the initiative petition.

The Citizen's Alternative Plan proposed the following:

- temporarily limits on the development of new downtown office space to an average of about one million square feet a year (exempting all new small buildings);

- a 450 (35-40 story) height limit on skyscrapers in the Office Core zone, and no new skyscrapers in the 12-block Retail Core zone around Westlake Park and major department stores;

- a reduction in the allowable density (square footage) of new office development to reduce impacts;

- increased incentives to preserve low-income housing through the transfer of development rights; and 
- required study by city planners of measures for the longterm management of Downtown development, taking into account factors such as progress toward implementation of a regional lightrail system; compliance with low-income housing goals; the effect of Downtown development on the affordability of housing in the City's neighborhoods; the cost of infrastructure and utility improvements; downtown traffic problems; and the attainment of clean air standards (see Figure 21).

The chief opponent of the CAP initiative was the Downtown Seattle Association in coordination with the construction unions. DSA's "Citizens For a Better Downtown" argued that the initiative would destroy the compromises folded into the 1985 Land Use and Transportation Plan. LUTP was described by this group as "a commitment to manage the quality of growth for the benefit of all through sensitive planning and regulation and prudent public and private investment." This group raised over $\$ 180,000$ while the pro-CAP group raised only $\$ 14,000$. Again in contrast to the CAP forces which raised money in small amounts from individuals, the anti-CAP forces raised its money from organizations such as developers, architects, contractors, brokers, banks and title companies (see Tables VIII and IX).23

Despite Citizens for a Better Downtown's direct mailing campaign to the 40,000 voters who voted in each of the previous four campaigns, the measure passed 62 percent to 38 percent on May 16, 1989.24 Voters ignored the Seattle City Council imposition of interim controls prior to the election and a promise to review the 


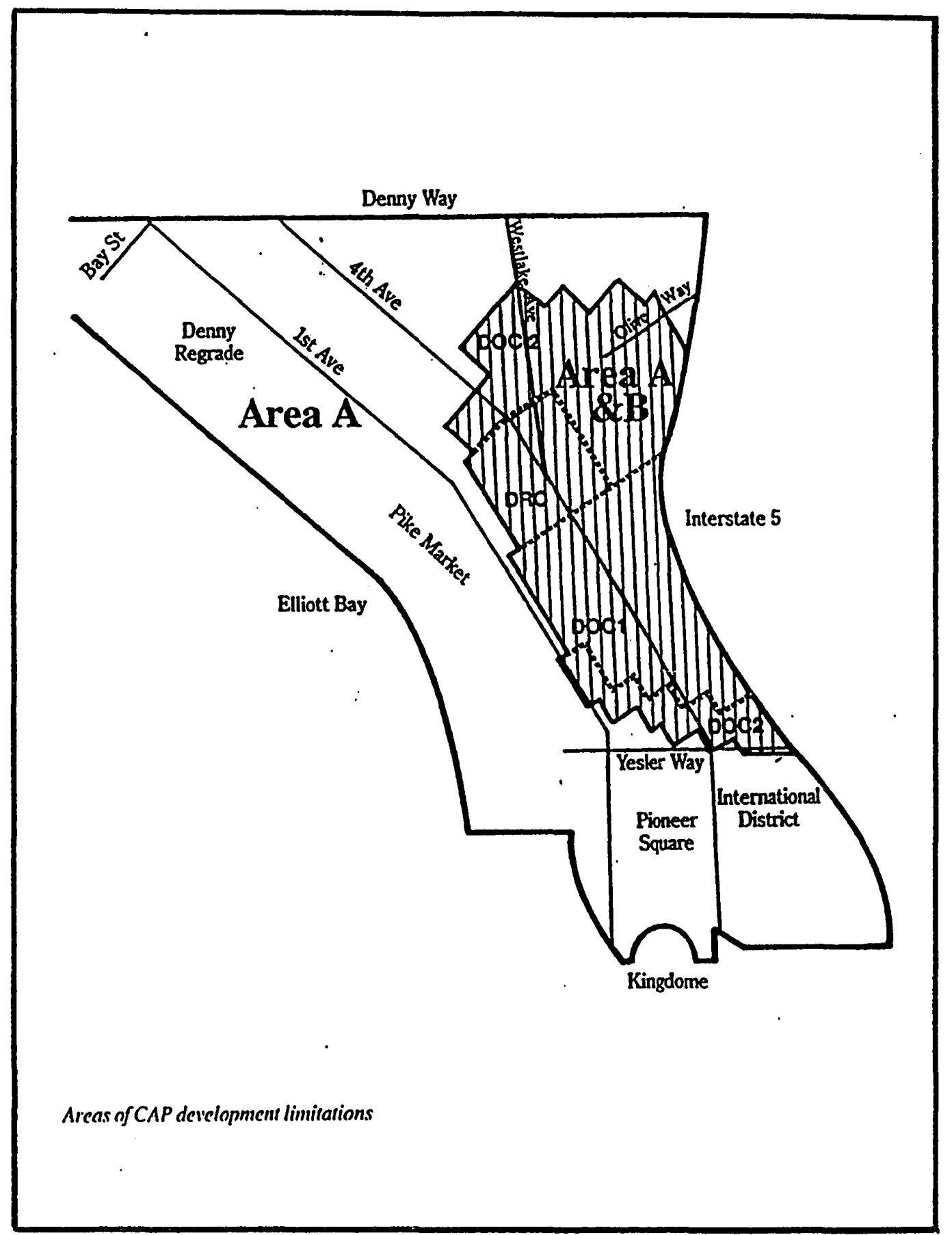

Figure 21. CAP Height Limits. From Arcade Magazine, "CAP: The Citizen's Plan," April/May 1991. 
TABLE VIII

\section{SOURCE OF ANTI-CAP FUNDING BY INTEREST GROUPS}

Developers

Banks

Contractors

Manufacturers

Real Estate

Utilities

Architects and Engineers

Hotels

Business Associations

Lawyers

Accountants

Retailers

Unions
$\$ 26,200$

$\$ 22,530$

$\$ 19,460$

$\$ 15,500$

$\$ 14,784$

$\$ 12,000$

$\$ 10,850$

$\$ 10,300$

$\$ 8,937$

$\$ 6,150$

$\$ 5,325$

$\$ 4,900$

$\$ 4,290$ 
TABLE IX

SOURCE OF ANTI-CAP FUNDING BY INDIVIDUAL CONTRIBUTORS 19

The Boeing Co

$\$ 10,000$

U.S. West

$\$ 10,000$

Seafirst Bank

$\$ 6,000$

Security Pacific Bank

$\$ 4,315$

Washington Mutual Bank

$\$ 3,000$

First Interstate Bank

$\$ 2,500$

Sellen Construction

$\$ 4,000$

Wright Schuchart Inc. (construction)

$\$ 3,000$

Wright Runstad and Co. (developer)

$\$ 4,500$

Prescott Development Co

$\$ 4,500$

Unico Properties (developer)

$\$ 4,500$

IntraWest Corp. (developer)

$\$ 3,500$

Norman Co (real estate consulting)

$\$ 2,600$

Vance Corp. (property management)

$\$ 4,227$

Seattle Chamber of Commerce

$\$ 5,000$

Downtown Seattle Association

$\$ 2,737$

Iron Workers District Council

$\$ 2,737$ 
regulations. A subsequent survey found that voters had supported CAP because of: a perceived need to plan development, to control growth impacts, and to reduce building height and environmental and traffic congestion impacts. The urban regime was revealed to be out of touch with the electorate. 25

Initial intentions to revise the CAP limit by 1991 have been stopped by a shift in the market from office to housing. While only one of the five vested office projects may be built, over 3000 new units of market-rate housing have been proposed. Office growth has slowed just as the housing market has heated up. Affordable housing has become even scarcer (see Chapter VIII).

\section{CONCLUSION}

In 1973, Seattle let slip a golden opportunity to write a downtown plan. Seattle was in a position to use the Seattle 2000 Commission Goals for Seattle as a framework for downtown expansion and attention to quality of life issues. Such a plan would have been based upon the Goal 2000 Commission consensus on the strong need for a regional center. However, the urban regime of the time may not have accepted restrictions based upon quality of life concerns such as design review or height limits, as in Portland. Instead, unlike Portland, Seattle planned from the periphery inwards, not reaching downtown until the beginning of the 1980 s. By that time, the city and region had grown greatly. New conflicts, issues and activists had come to the table. The older groups CHECC, the Municipal League, and the League of Women Voters - were 
unwilling or unable to create a new spirit of Seattle. These interest groups were replaced by urban design, environmental and housing activists who had learned to distrust city hall. Ultimately, a plan based on pro-growth sentiment (and fearful of cyclical downturns in Boeing employment) was equated by a majority of voters to the growing congestion and perceived deterioration in the quality of life.

Figure 22 provides an overview of answers to the research questions posed by this dissertation. At the beginning, the urban regime was able to set the parameters of policy on the basis of the standard economic development agenda. Downtown had to grow to remain the region's unchallenged center. The Land Use and Transportation Plan was organized as a top-down plan in which City Hall issued guidelines which assumed that proper types of growth could grow the downtown out of its problems. For example, housing could be created as a condition of a development review approval. The guidelines also assumed a positive connection between downtown growth, regional dominance and city well-being, as in Portland. The guidelines constrained the limits of discussion. But Allied Arts and the Sierra Club offered alternatives which challenged the downtown establishment's preference for prestigious tall office towers and sizable rentable floor area. The general cohesiveness of the narrow land use alliance prior to the CAP election can be indicated by the relative invariability of the guideline throughout the process whose stages included complex requirements for citizen involvement such as alternative "soft" and "hard" proposals; the environmental impact statement process, 


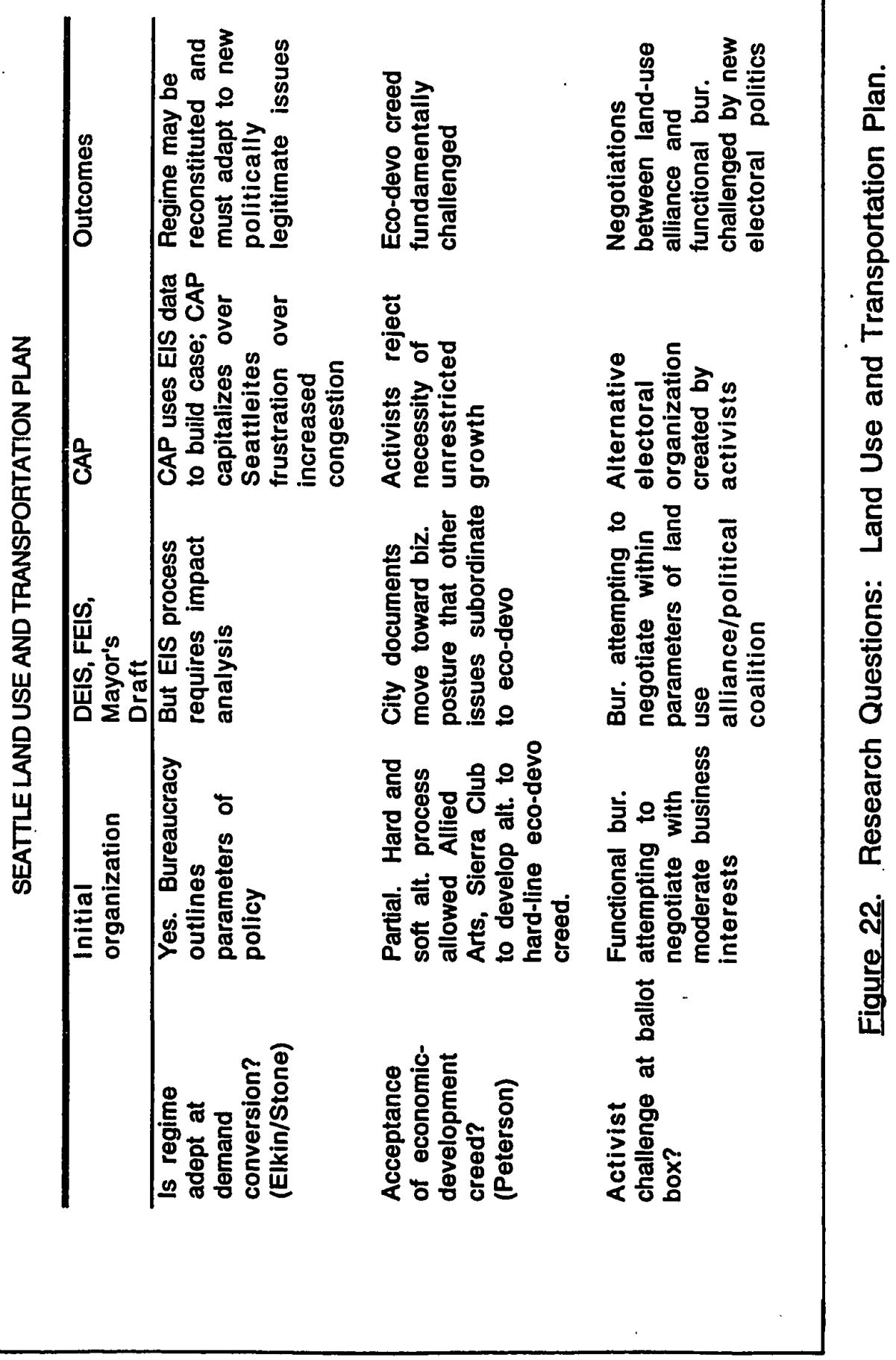


including comments and responses; Planning Commission review of the Mayor's draft; and the ultimate City Council public hearing. Initial proposals to restrict heights, to introduce housing linkage requirements, and to modify the existing floor area bonus requirements were modified to meet the DSA's objections. Urban design considerations were introduced as zoning standards to be negotiated between city staff and business representatives rather than design guidelines to be interpreted by the community design review board. In general, city planners and the downtown business association came to an agreement which avoided restrictions in the core but ratified citizen activist victories in the periphery historic preservation in Pike Place Market, and Pioneer Square; and pro-housing policies in Denny Regrade, Belltown and the International District. By following proposals for floor area limitations and amenity floor area bonuses, the relative strength of the various interests can be quantified. Allied Arts and Sierra Club proposals were not adopted although these "radical" proposals no doubt gave planners leverage. The EIS process documents how planners defended their plan against vociferous citizen activist criticism. Clearly, activist concerns were not incorporated into the LUTP prior to pro-forma City Council approval in 1985. The Council was not called upon to discuss the question of limited growth or the congestion and costs involved in getting everyone and everything downtown.

The Citizen Alternative Plan became a referendum on the progrowth policies of the urban regime. The CAP referendum 
fundamentally rejected any characterization of LUTP policies as "developmental" and therefore in the public interest (Peterson's theory). The urban regime tried to override the demands of the environmentalists and neighborhood and housing activists by characterizing CAP as anti-urban and pro-suburban sprawl. Although downtown interests poured money into the campaign, the EIS reports on LUTP and the Washington Mutual tower provided material for CAP's arguments. Each side was compelled to describe its vision of the public interest. The election became a referendum on the deteriorating quality of life in a period of intense growth throughout Puget Sound.

A new politics has emerged which awaits the test of a new boom. Seattle is again experiencing a mild "bust." Boeing employment grew from approximately 60,000 workers in 1985 to over 100,000 in 1989. Boeing employment will decline to a projected 80,000 workers in 1994.26 Would the public again adopt the CAP referendum? I suspect that like the defeated Forward Thrust transit bond issue, the public supports quality of life stances during good times, and specifically high Boeing employment. But the very need for public support indicates that the urban regime no longer can negotiate a plan without weighing potential electoral challenge from Vision Seattle.

A comparison between the two cities indicates that while the Portland urban regime has expanded to the eastside, the Seattle regime has seen neighborhood concerns interfere with previously isolated core issues. The economic development strategy in 
Portland remains strongly pro-growth with new opportunities based upon a regional light rail system centered on the core. But Seattle's downtown program is threatened by a new popular perception that downtown growth contributes to a deteriorating quality of life. In Portland, activists are unable to mount successful initiatives or openly back candidates, whereas in Seattle the urban regime has lost pro-growth projects (Seattle Aquarium) and pro-growth land use policies (LUTP). Politicians like Margaret Pageler question the orthodoxy. 


\section{ENDNOTES}

${ }^{1}$ A FAR of ten to one means that the floor area of a building may be ten times that of the site. That is, ten stories at $100 \%$ lot coverage, 20 stories at $50 \%$ lot coverage, 40 stories at $25 \%$ lot coverage and so on. Buildings can assume any configuration as long as this ratio is preserved.

2Donald Monson, Comprehensive Plan for Central Business District - Seattle, 1963.

${ }^{3}$ Seattle 2000 Commission, Goals for Seattle; pp. 30-33.

${ }^{4}$ Seattle City Council adopted Resolution 24283 on September 4, 1973. Resolution 24282 declared the intention of the city to adopt a comprehensive policy plan each year by the first Monday in July, and a program of implementation of the Seattle 2000 Commission goals and objectives. Mayor Uhiman concurred.

5The Land Use and Transportation Plan was adopted by Council Resolution 278281 on June 10, 1985.

${ }^{6}$ City of Seattle, Office of Policy and Evaluation, Background Report of the Downtown Land Use and Transportation Project, p. 4.

${ }^{7}$ City of Seattle, Office of Policy and Evaluation, ㄴUTP Background Document, pp. 4-7.

${ }^{8}$ Downtown Seattle Development Association, "Firm Alternatives," pp. 1-7.

${ }^{9}$ Sierra Club Urban Committee, "Seattle Downtown Plan Firm Alternatives," p. 1.

${ }^{10}$ Allied Arts of Seattle, "Firm Alternatives," pp. 8, 9, 12, 13, $20-26$

11 The Allied Arts Plan reduced floor area from 18:1 in the office core to 12:1 along SW Third and 9:1 in the First Avenue corridor. The retail core far was reduced to 5:1. The maximum height limit in the most intense office core would be $\mathbf{5 0 0}$ feet. Strong frontage heights would be lowered to 250 feet along Third and 125 feet along Second. Maximum height in the retail core was 165 feet but only 125 around Westlake Park.

${ }^{12}$ Citizens Alliance for Urban Seattle, "CAUSE Hard Alternatives," summary, pp. 1-2.

13Downtown Neighborhood Allance, The Issue of Downtown Growth - Limits to Growth, p. 9. organization.

14The process called for "soft" and "firm" proposals from each participating

${ }^{15}$ City of Seattle, Land Use and Transportation Project, Draft Environmental Impact Statement for the Land Use and Transportation Plan for Downtown Seattle, p. 9.

${ }^{16}$ City of Seattle, Land Use and Transportation Project, Draft Environmental Impact Statement for the Land Use and Transportation Plan for Downtown Seattle, p. 145. 
${ }^{17}$ City of Seattle, Land Use and Transportation Project, Mayor's Recommended Land Use and Transportation Plan for Downtown Seattle, p. 3.

${ }^{18}$ This narrative and others descriptions regarding negotiations between the development community, interest groups and the planning staff are based upon the correspondence generated during public review of LUTP and interviews with Bill Duchek and other Seattle Long-range planners in July, 1990.

19 Jeannette Williams, Seattle City Council, CAP notebooks are the only documents in the Seattle archives.

${ }^{20}$ Bill Duchek, LUTP, Memorandum "Assignment of Floor Area Bonus Values for Downtown Public Benefit Features," December 3, 1985.

${ }^{21}$ Walter Hatch, Seattle Times, untitled, undated, unpublished background for a possible news article.

${ }^{22}$ Seattle Times, "City Limits," May 1, 1989. See also articles by Rebecca Boren, "Is Vision Seattle Too Nearsighted?" Seattle Weekly, January, 1988, and by Eric Scigliano, "Vision Seattle Looks Ahead: Will There Be Life After CAP for the Citizen Coalition?" Seattle Weekly, August 16, 1989 and Chris von Veh, "The Vision Thing: The Citizen's Alternative Plan and Planning Anxiety," Arcade, February/March, 1989.

${ }^{23}$ Seattle Times, "Anti-CAP Group Attracts $\$ 180,000$ in Donations," May 7, 1989.

${ }^{24}$ Seattle Times "A Feather in Their Cap. Group of Neighborhood Activists Has Last Laugh," May 17, 1989. The final vote tally was 42,643 to 26,303 .

${ }^{25}$ Elway Research, Inc., Downtown Development Survey, November, 1989, pp. A14A15.

${ }^{26}$ Seattle Post Intelligencer, "Boeing to cut 19,000 jobs here in the next 18 months," February 19, 1993 
CHAPTER V

PORTLAND MORRISON STREET PROJECT

CADILLAC-FAIRVIEW

On March 20, 1979, the Portland Development Commission (PDC) approved Resolution No. 2680 which authorized the Commission to review a proposal from Cadillac-Fairview Corporation of Toronto, Canada to redevelop four downtown blocks between SW Morrison and SW Taylor and between SW Fifth and SW Third Avenues. 1 These blocks were envisioned as an anchor to the Downtown retail core which had been losing market share to the suburbs. Their location between SW Fifth and SW Third would provide a link between downtown and the waterfront (see Figure 23). The 1972 Downtown Plan had called for maintenance of a compact retail core which was defined as the blocks fronting on SW Morrison, Alder and Washington Streets from SW Third to Tenth. (East of the retail core, the city hoped to establish a "waterfront retail/exhibition center.") The retail core was expected to be "compact, colorful, intense and exciting" with such a strong pedestrian environment that an entirely auto-free shopping precinct was deemed ideal.2 The original plan did not envision an anchor to the retail district; the future site of Pioneer Place was simply indicated as a potential redevelopment site. The retail district was to be tied together by a massive system of "skyways" running 
The

Project

Site

The site for the Morrison Street Project (Map 3) is centrally located within the downtown core at the eastem end of the retail district. The

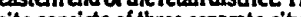
site consists of three separate dity blocks of to, 200 quancleet each (200 feet by 200 (eet) for a total of approximately 275 ages. The ' $L$ -

straped site includes Blocks 60 and 61, bounded by Fifth Avenue, Tyylo Street, Fourth Avenue and Morrison Street and Block 50, bounded by

Fourth Avenue, Yamhill Street.

Third Avenuse and Morrison Street.

The coiner of Fifth and Morrison has

lons been considered the "1005"

retail comer in the downtown.

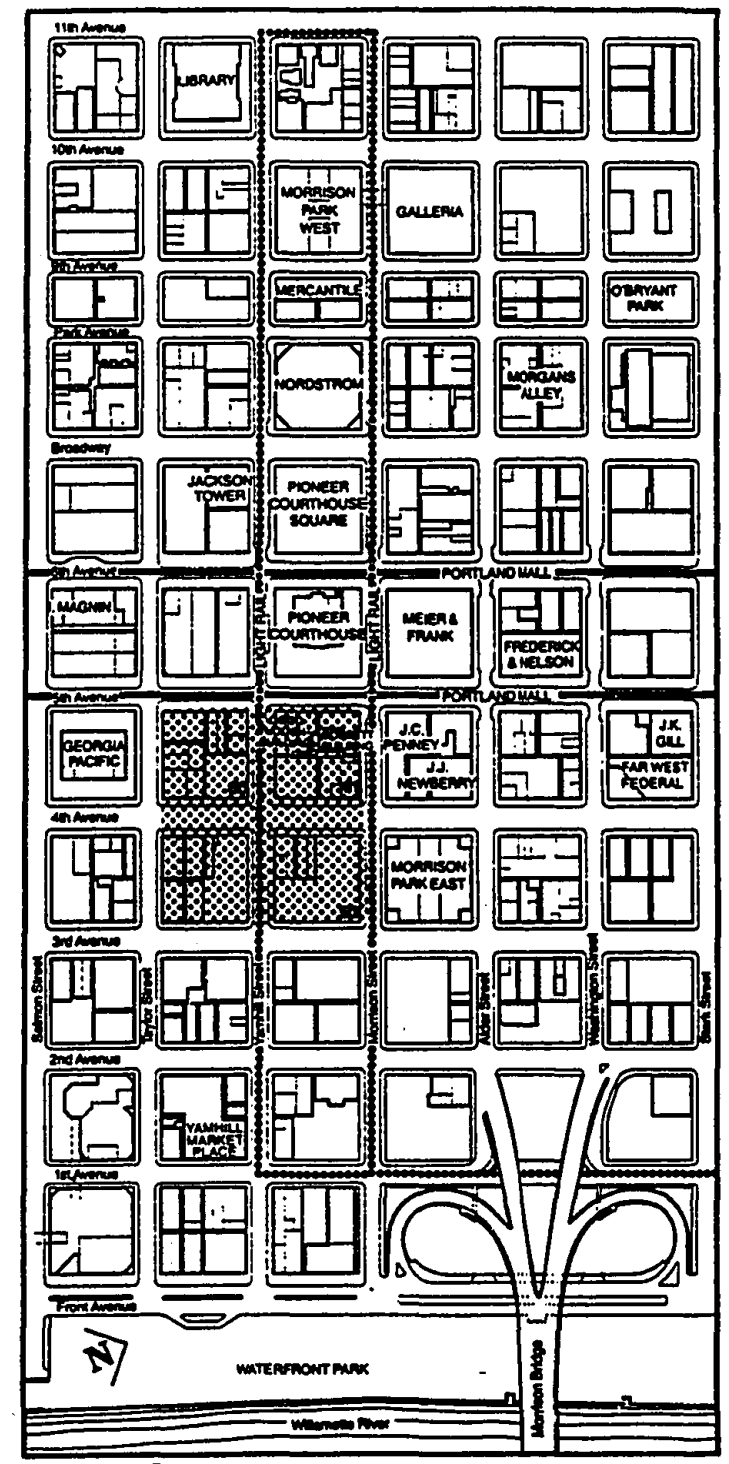

Map 3 - Site Area

Figure 23. Morrison Street Project Site. From City of Portland, Portland Development Commission Request for Qualifications. Morrison Street Project (1982). 
midblock down the Morrison/Alder corridor.

As a major implementation step, City Council adopted the Downtown Waterfront Urban Renewal Plan in $1974 .^{3}$ The urban renewal plan recognized that the area between the retail core and the waterfront along SW Yamhill was underused, a mix of parking lots and vacant buildings. The area was expected to accommodate offices, housing, convenience and specialty retailing. This four block site between SW Morrison and SW Taylor and between Pioneer Courthouse Square and the Yamhill Historic District had never enjoyed local prominence, being "jumped over" when the 19th Century Courthouse and big department stores had moved to SW Fifth Avenue. Although Pioneer Courthouse and the big downtown department stores had been built west of SW Fifth, little investment was evident east of SW Fifth. Aside from two medium scale office buildings along SW Fifth the area was "underdeveloped" with onestory buildings mostly housing downtown trade restaurants. The area was well suited to be included within the Downtown Waterfront Urban Renewal District. But by the end of the decade, the city realized that something bigger was needed. The city, especially Neil Goldschmidt, who had become Mayor in 1974, saw the need for a project which would begin generating tax increment revenue to fund the plan.

Although the resolution spoke of "serious study and consideration" and "broad public review from interested groups," there had been none to that point. PDC had had preliminary discussions with Cadillac Fairview and the Canadian firm had 
developed some diagrammatic concepts but PDC was already firmly committed to the proposal. Few people knew about the project until immediately before the resolution was brought before the Commission. 4 Cadillac-Fairview did not yet have a local architect working on the project. However, they had an excellent reputation and was one of the few firms experienced in multi-block urban redevelopment projects. Within 60 days of the receipt of a proposal, the Executive Director of PDC was to transmit copies of the proposal to the Planning Commission and City Council, schedule a public hearing and make a formal recommendation to City Council regarding "disposition of this proposal." The Planning Commission's role would be limited. It would be asked to review the project at the end of the process with the formal amendment of the urban renewal plan.

The Development Commission scheduled a public reception immediately after formal business to celebrate. It seemed as though downtown would get its long sought after retail anchor, the downtown shopping malls.

The Cadillac-Fairview project proposal promised a mixed use complex in the heart of downtown. Four downtown blocks would be filled with a full-line department store and an I. Magnin store, (approximately $260,000-410,000$ square feet), 100 specialty retail shops (190,000 square feet), a 250-350 room Radisson Hotel, 300,000-500 square feet of office space, and 1,000-1,300 parking spaces, The city estimated a potential for 1,300 new jobs, $\$ 1.5$ million in annual property tax receipts and $\$ 150,000$ in hotel tax receipts. Urban renewal activities would require a $\$ 10-\$ 12$ million 
subsidy. The project would eliminate apparently insignificant uses (see Figure 24). One block contained a restaurant and deli, beauty school and a three-quarter block surface parking lot. Another block contained two restaurants, retail nautical supplies store, market, low-income housing (Gilbert Building/Taylor Hotel), and half-block surface parking. A third block contained the Corbett Building with a variety store and an optical shop on the ground Floor; the Goodnough Building with a meat market, bar, card shop and candy store on the ground floor; the Russell building with a restaurant, optical shop and women's wear and the Fred Meyer Building. The fourth block contained a public market, a bookstore, bar, the U.S. Army recruiting office, a religious shop, the Chamber of Commerce and a quarter block surface parking lot. These blocks included vestiges of the old Portland, such as the Bauer and Boston public market. Altogether, the Cadillac Fairview project would replace 43 retail establishments, 400 housing units (the Taylor Hotel), 59 commercial offices, and one and one-half blocks of surface parking. Of 16 buildings in these four blocks, none were judged by PDC to be in good condition. Two were in fair condition, three were in poor condition, and eleven were in bad condition. 6

These local businesses and local owners had not been party to the preliminary negotiations. The eventual spokesman for the merchants group first read the news in the paper. The local merchants then were invited to a briefing with PDC and were 


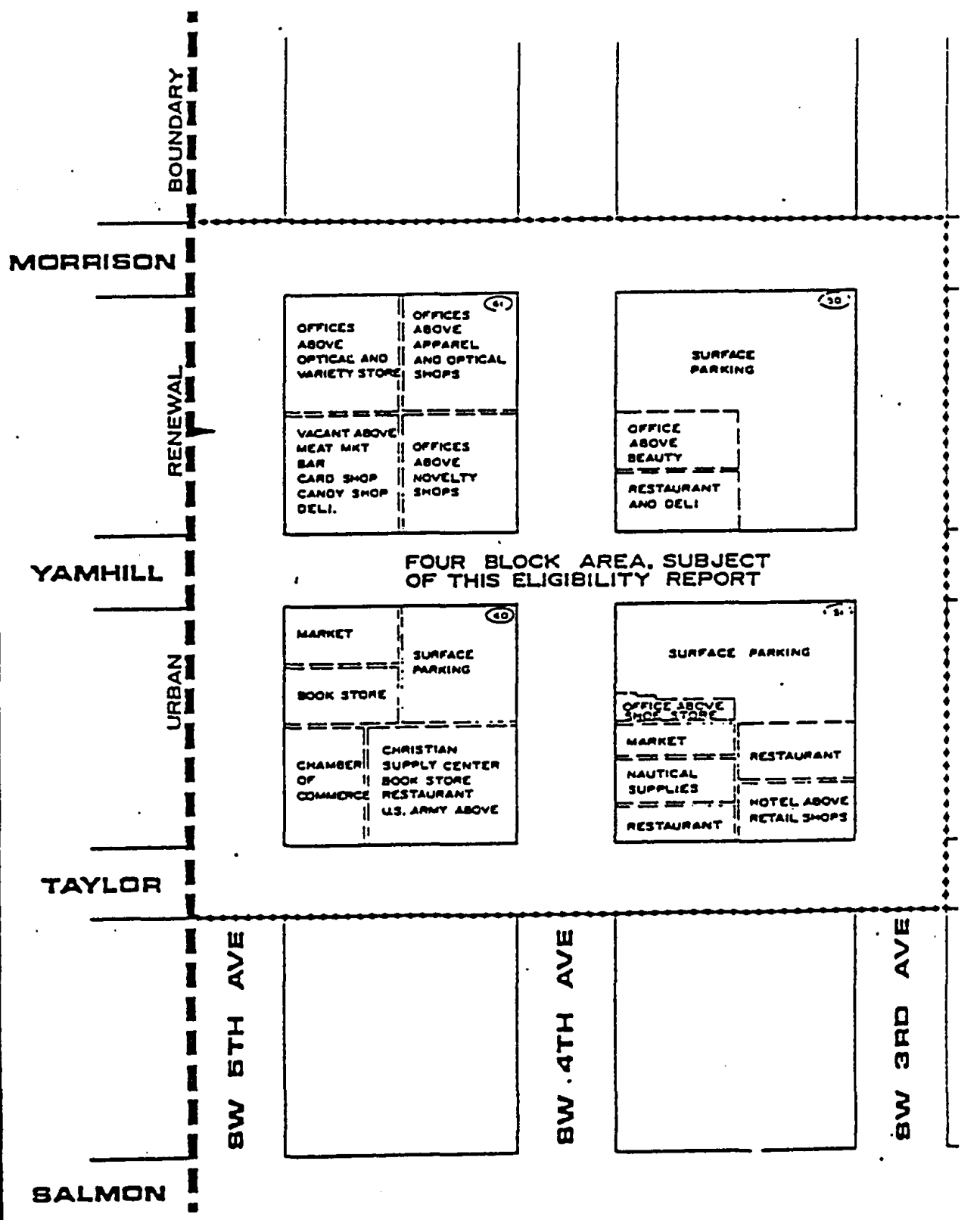

Figure 24. Morrison Street Project Site Land Use. From Patterson and Stewart, Report on the Existing Conditions Within Block 50, 51, 60 and 61 (1979). 
informed by PDC in a way that seemingly left no room for them.

These merchants, who included several Vietnam War era activists, had succeeded in developing small independent businesses and did not like what they perceived to be a condescending attitude on the part of the city. Newspaper stories echoed the theme of the City's 1960s urban renewal projects - obsolete buildings, displaced owners and businesses. ${ }^{7}$ The Oregonian ran a pictoral obituary eerily similar to the photos of the small immigrant merchants displaced by the South Auditorium urban renewal project. Some of these businesses had already been the object of urban renewal. The very popular Dave's Deli had moved once before when the Portland Development Commission had obtained a city block for the Morrison Park East parking garage. Ironically, many of the city officials who proposed to displace the deli were frequent customers.

Mayor Goldschmidt was committed to the project because it would generate tax increment financing for a new convention center and anchor downtown retail. The only issue for him was financial feasibility. Fair value for lands taken for the project, adequate parking and project design were expected to be the significant issues. The Oregonian recorded the "local color vs. flashy new stores $^{n}$ issue only as nostalgia for the old days.

\section{Opposition}

Within two months the issue became one of people vs. progress, at least as reported by the Oregon Journal. Planning Director Ernie Bonner of the Planning Bureau argued for progress but urged preservation of the more significant buildings. (The Planning 
Bureau was subordinate to the Office of Planning and Development. The Portland Development Commission also reported to OPD.) People advocates included Michael Stoops, a low-income housing advocate, who decried the destruction of the Taylor Hotel low-income housing and Martin Gix of the Downtown Community Association who stated that the project was too big and would erase all traces of Portland. 8 The proposed project connected seven blocks with skybridges and created visual barriers 760 feet in length both north-south and east-west (see Figure 25). Most significantly, the Society of Industrial Realtors called the City's closed dealings with CadillacFairview a moral issue and called for open identification, acquisition, and disposal of urban renewal land. The Chamber of Commerce opposed public subsidies to the project.9 Thus, design/historic preservation and low income housing displacement issues complemented a Portland conservatism which resented PDC's closed negotiations with a Canadian developer.

PDC conducted two public hearings on April 18, and June 27, 1979. A total of 450 attended the hearings and expressed concerns about project design, historic preservation, public costs for relocation of utilities, parking and the closed process itself. 10 Most downtown businessmen and their attorneys/consultants were heartily in favor. Bill Naito, not closely associated with the retail core but a major property owner north of Burnside, tried to compromise, offering support for the project while arguing for saving some of the buildings. An insignificant player, Gregory Clouse, a resident of the Taylor Hotel, talked about the threat of 


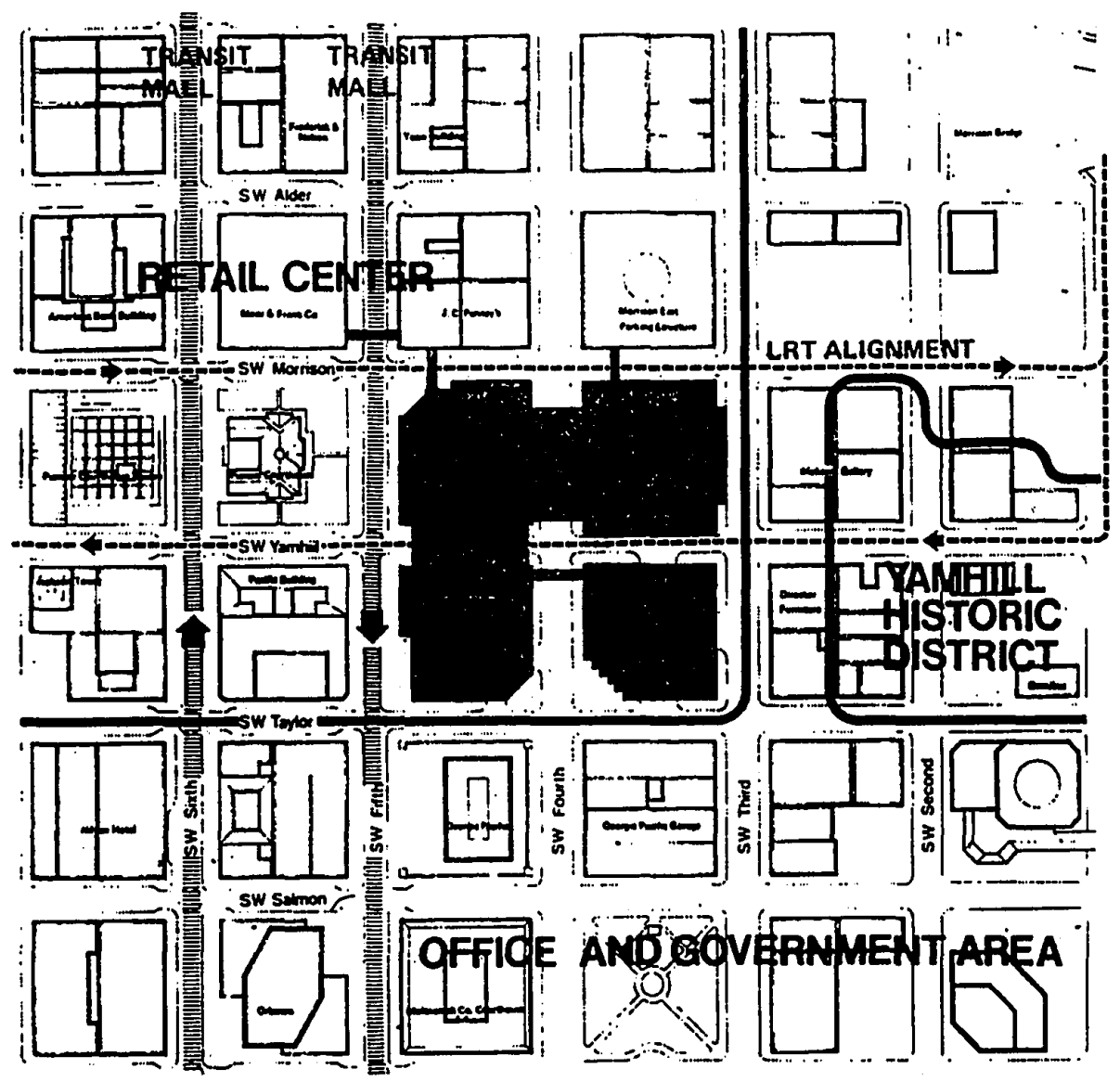

CADILAC FAIRVIEW PROPOSAL $\cdot$ NORTH

Figure 25. Cadillac Fairview Skybridges. From Patterson and Stewart, Report on the Existing Conditions Within Block 50,51,60 and 61 (1979). 
multi-national investment capital. The most compelling criticism came from Walter W. McMonies, Jr. an attorney representing both the Downtown Community Association and Metzger-Parker Company, which managed the Russell building, located within the project area. These parties were not opposed to the introduction of additional retail space into the project area but raised several questions:

whether the city should condemn property which was not blighted and owned by local owners in order to sell to absentee landlords; (2) what effect this threatened condemnation would have on the ability to lease space; (3) whether commercial displacement would be caused by the increased rents necessary to finance the project; (4) whether the project would result in the displacement of other businesses and housing, especially the likely disappearance of SRO housing; (5) whether increased traffic would impact air quality; (6) whether the project was too massive in scale with its seven skybridges and finally, whether the threatened Goodnough and Gilbert Buildings should be preserved.

PDC responded to these criticisms. The agency explained that the staff had made a presentation at an Urban Land Institute conference in June, 1978, to a large audience of private developers. Cadillac Fairview had subsequently approached the city and was asked "under the direction of Mayor Neil Goldschmidt, as Commissioner-in-charge" to present a detailed proposal. This was done in order to avoid creating uncertainty and resultant blight following a public process of site identification and request for proposals. 11 
As a result of the controversy, the project concept was somewhat modified. One of the most prominent local architecture firms, Zimmer, Gunsel, Frasca, was retained to alter the project concept. The facade of the Goodnough Building was retained and the Gilbert building/Taylor Hotel was to be moved across SW Third to be saved for housing. This effort was proposed to mollify the preservationists. The architect also endeavored to reduce the monolithic quality of the project by designing contrasting components and scaling down the width of the skybridges. ${ }^{12}$ in July 1979, the project won PDC approval with qualifications. The staff report noted that the city was "unlikely to achieve the adopted goal of enhancing the retail core and expanding it easterly" without this proposal. The staff suggested additional requirements such as a deli; an open air market; space for displaced merchants at less than market rates, relocation assistance; and replacement housing. PDC approved the general concept minus the skybridges linking the four blocks to other downtown properties. The project still contained 160 foot wide retail skybridges which made the four blocks into one big superblock. ${ }^{13}$ The Planning Commission also approved the project but balked at the make or break skybridge issue. CadillacFairview had continued to insist on skybridges which effectively destroyed the downtown distinctive pattern of small 200 foot by 200 foot blocks. Architect Robert Frasca of Zimmer, Gunsel, Frasca, offered to stake his professional reputation on his ability to make the retail bridge, skybridge system into "urban streets." The Planning Commission called for a study of the skybridge issue. The 
Commission did not have formal authority over the project. It did not officially participate in granting permits to allow skybridge encroachments over the street except to render advice.

Many Portlanders were not happy with the project. An August 7, 1979 Oregon Journal straw poll found that 196 of 250 readers found the project "bad for Portland," that 222 faulted the condemnation process, that 201 disliked the retail bridges, and that 227 were opposed to a subsidy. ${ }^{14}$ A prominent consultant, Don Barney, criticized the proposal for its internal orientation and skybridges.

In spring 1978, President Carter appointed Mayor Goldschmidt Secretary of Transportation. There was concern that without Goldschmidt, the project would falter. A new mayor, Connie McCready, had been appointed by City Council to fill out Goldschmidt's unexpired term. McCready was committed to the project, but expressed some concerns about condemnation precedent and the skybridges.15 After a Council informal discussion of the PDC recommendation for approval, 16 Mayor McCready directed the City's Office of Planning and Development to conduct a detailed study of the project which considered economics, planning/design, transportation/parking, historic preservation and renewal financing. 17 Don Barney, a prominent local consultant, coordinated the efforts of a team of experts. In December, 1979, the OPD report was issued, endorsing the project with some qualifications.18 OPD supported the thrust of the Downtown Plan which called for public action to create a retail core. Without a city-funded project, using 
eminent domain and tax increment financing, this opportunity for a retail anchor would disappear. Only the Corbett and Gilbert buildings would remain and the small businesses would be replaced in any event by office buildings blocking the extension of the retail core toward the Yamhill Historic District and the river. "A multiblock development was required to achieve "critical mass" with direct pedestrian connections and suitable parking necessary to lure a major department store."

OPD not only supported the rationale for the project but also defended PDC's secretive dealings with Cadillac Fairview: "The City is dealing with Cadillac-Fairview because the company represents a level of interest and expertise not previously seen." Only CadillacFairview had made a formal proposal. A more open process would have taken two or three years and created an "unacceptable" cloud over the four blocks. However, OPD also advocated redesign of the project to reduce the mega-structure look from a distance and a tunnel feeling at street level. The retail sky bridges would have to be scaled back and retailing should be re-oriented to the streets. The OPD report was an attempt to get ahead of the ball. The report created the necessary arguments to approve the project while isolating issues that could be negotiated with the company.

On December 19, 1979, over 400 citizens attended the public hearing with the majority in opposition. An interesting new complaint by Clyde Brummel, President of the Oregonian Homeowners Association, attacked the project as "corporate welfare."19 Despite criticism by citizens and hard questioning of 
the experts by Council, Cadillac-Fairview insisted that the project could not be made smaller or skybridges sacrificed.20 Mayor McCready publicly expressed her concerns - the need for further modifications regarding the density, design and use of retail bridges . and skybridges. Locally prominent attorney Steve Janik privately negotiated the size required for the skybridges on behalf of the developer.21

In the public's mind, the skybridge issue remained symbolic of the developer's and Development Commission's disregard for the public interest. The developer insisted upon "encroaching" upon the public's right-of-way in order to provide a "retail bridge" between each of the blocks. The architect for the project speculates that the developer would have settled for a $\mathbf{5 0}$ foot wide retail bridge, sufficient to allow a single row of retail shops of 35 foot width and an additional 15 feet for pedestrian traffic. In any event, the ultimate project settled for fewer, narrower pedestrian bridges without retail. On January 31, 1980, Council approved the project. Mayor McCready and Commissioners Ivancie, Lindberg, and Schwab outvoted Commissioner Jordan. Commissioner Jordan cited the opportunity to seek other development proposals from local firms. 22

Criteria for negotiation were set out (although these criteria could be modified.) These related to sufficient retail space, including a major department store; a hotel with at least 250 guest rooms; a fresh fruit and vegetable store and a delicatessen; limits on skybridges - one per block face and retail skybridges no wider than 110 feet; the department store could encroach 10 feet; an 
outward orientation; consideration to saving the Gilbert building and the facade of the Goodnough building (or spending money on preservation elsewhere); replacement of lost housing; including locally based businesses; rent reductions for merchants relocating to the project and construction scheduling to provide for relocating tenants; loans for new equipment; parking to be funded by parking revenue bonds; a $\$ 150,000$ letter of credit; a sharing of costs for liability between the developer and the city; use of tax increment financing money only; and a 90 day negotiation period (Ordinance 149087 and Res. 32603). Like the OPD report, City Council action positioned the city to approve a "hot" project by isolating public concerns for eventual negotiation.

During this negotiation period, citizens organized. There were three distinct sources of opposition. These were not only the businesses who would be displaced but also the Downtown Community Association and Save Our Livable Downtown, an ad hoc protest group of citizens, architects and preservationists. Bureaucrats at City Hall offered surreptitious help. By June 6, 1980, over 7,800 signatures were gathered on an initiative petition. The initiative petition would have required low and moderate income housing to be incorporated into an urban renewal project using tax increment financing. These projects would also have to go to a public vote. This initiative was signed not only by prominent opponents such as Howard Glazer and Terrence O'Donnell but also Frank Ivancie. Ed Tenny, manager of an affected small business, became spokesman for 16 businesses suing the city. ${ }^{23}$ These 
merchants engaged in locally televised debates with PDC staff, lobbied City Commissioners and filed court papers in an effort to delay the project and build public opposition. These activists were pro-business but were frustrated by the City's inability to understand the small business environment and by its infatuation with mega-projects. The merchants wanted to be included.24

Demise of Cadillac-Fairview

Negotiations were extended but resulted in Cadillac-Fairview's withdrawal after six months. The city and the company could not come to terms on finances. Both project economics and the financial strength of the developer were shaky. Cadillac-Fairview wanted the \$20 million upfront regardless of how long it took to sell the bonds; a delay could result in a loss of $\$ 600,000$ to $\$ 1$ million. Cadillac Fairview also wanted the city to guarantee that it would repurchase the hotel site if a hotelier could not be found. And, Cadillac Fairview wanted the width of the retail bridges finalized. This type of design issue was of less importance to the City Council but was crucial to Cadillac-Fairview.25 Persons interviewed for this study split over whether the conditions of approval were serious roadblocks. City Council may have been willing to renegotiate if Cadillac Fairview had not withdrawn. Alternatively, the conditions of approval may have represented a good faith effort by Council to attach significant conditions while securing an important retail project. With the Cadillac-Fairview proposal dead, the merchants dropped their lawsuit in exchange for PDC's promise to revise the 
selection process. The "1000 lb. gorilla" project was to be rethought.

\section{ROUSE ENTERS THESCENE}

The Council quickly reaffirmed its support for a Morrison Street Downtown Development Project "in order to fulfill the retail goal of the Downtown Plan."26 Bill Roberts, chair of the Development Commission, clearly understood the need to build on the momentum that downtown had recently achieved in rebuilding its retail core. Mayor Goldschmidt had worked hard to get national retailers such as Nordstrom and J. C. Penny to build or renovate downtown. A new, prestige retail anchor was needed to cement these commitments. Furthermore, these blocks at the 100 percent downtown corner remained the last prime parcel of real estate available to meet the goal of extending the retail district east to the river. PDC's reputation and ability to deliver were on the line.

A new public acquisition process was adopted by Council on August 6, 1980. This was a crucial break with the past. Up to this time, PDC could condemn any block. Commissioner Schwab put through Council a requirement that property acquisitions be made through amendment of the Urban Renewal Plan and review by the Planning Commission and approval by Council. Throughout the Cadillac-Fairview phase, the issues of major public concern had not been dealt with outside the context of the Cadillac Fairview proposal. What PDC needed was to isolate these issues outside the emotional framework of a specific proposal. Then the selection 
process could conform with predetermined objectives in an open process. Resolution 32723 provided for a different process: concept development, an amendment to the urban renewal district, request for and selection of proposals, plan refinement by PDC and the developer, and necessary public reviews. At this time, the Planning Commission also adopted new policies to address previous public controversies. These included urban renewal acquisition of property through a public process and a skybridge policy to guide the next project. From November, 1980, to March, 1981, PDC conducted a public review process to create the conceptual plan27 PDC met with the newly formed downtown business association, the Association for Portland Progress; the Building Owners and Managers Association; the Chamber of Commerce; the Downtown Community Association; the Planning Commission; the Design Commission; the Landmarks Commission; the Yamhill Historic District Advisory Committee and others. The Development Commission published "Outlook and Options for the Morrison Street Project" in March and an "Action Plan for Downtown Retail Development in Portland, OR" in June, 1981.

With this process, the City made a fundamental shift to an urban renewal program based upon public polices put in place prior to the developer selection process. The old urban renewal project process would no longer serve as the standard PDC approach. The City's new process would answer the most telling criticism of local businesses that they were frozen out of the development game. A two-part process to select the developer, the request for 
qualifications (RFQ), followed by the request for proposal (RFP), responded to the concerns of local business interests that the process be open to them. The two-part process also guaranteed that a strong company would first qualify, then address the complex list of public issues. Urban design considerations were a minor part of the City's decision. A "beauty contest" would be avoided by reducing aesthetics/project design to 25 percent of the selection choice.

PDC was still pre-eminent as the Downtown Plan implementation agency. The city refused to allow the Planning Commission to co-author the development proposal with PDC. The city had made procedural but not institutional change.

The most significant aspect of the process conducted by Doug Obletz, PDC staffer, was the simultaneous but separate consultation with the public regarding the public issues and the development community regarding feasibility. Two detailed documents were published establishing the vision for the project - fashion and high quality retail - and setting out a detailed set of development guidelines.

The Development Guidelines document contained minimum and desired development square footage and function, and potential floor area bonuses for retail and for housing; parking and loading access requirements; consideration of encroachments in the right-of-way, and street-level pedestrian orientation; consideration of retention of the Corbett and Goodnough buildings; integration with the transit mall; and integration with the Yamhill historic district.28 The City asked for a minimum of 240,000 gross lease square feet of high- 
quality retail, including a minimum of 100,000 square feet of retail anchor space and 90,000 square feet of specialty shop, restaurant and/or entertainment space. The developer was also required to provide a $400-500$ room hotel or $300,000-400,000$ square feet of office space. Retail parking would require a minimum of 450-500 shopper parking spaces. At this point it was expected that a $\$ 12$ million subsidy would leverage a $\$ 130$ million project with two department stores, $90,000-130,000$ square feet of specialty retail with a four to six year payback.29 The City was also willing to grant floor area bonuses for retail or housing.

The tone of the introduction of the Development Guidelines indicated strong public involvement in the process to be undertaken. The project guidelines emphasized prior review of the project objectives by the Portland City Planning Commission, Portland Design Review Committee, Portland Historic Landmarks Commission, Portland Development Commission and Portland City Council.

Although the Development Commission maintains a flexible posture toward the design and development of the project, the following requirements and guidelines are intended to assure that the design of the Morrison Street Project meets the project objectives, conforms to City goals and polices, addresses key public concerns and meets the test of good urban design. These guidelines are meant to encourage the development team to produce an imaginative design concept of the project consistent with public objectives for downtown Portland and the Morrison Street Project.

The Planning Commission then held its public hearing and recommended approval. Council adopted the guidelines with little dissent on July 17, 1981.30 This anticlimax represents real success 
in touching base with all influential members of the downtown establishment.

The publication of the Development Guidelines for the Morrison Street Project represented the zenith of public representation. However, the small retailers who had opposed the Cadillac-Fairview project became irrelevant. PDC considered these retailers marginal. The OPD report made it clear that they would be swept away by inevitable private development. Urban Renewal would give them relocation recompense and they were promised right-of-first refusal to lease space in the new project.

PDC authorized acquisition of Blocks 50, 60 and 61 on August 11, 1981 (PDC Resolution 3024). The Commission established the "fair reuse value of the land for uses developed in accord with the urban renewal plan to be $\$ 6,500,000$ adjusted for inflation" (PDC resolution no. 3129, June 11, 1982). The Downtown Waterfont Urban Renewal Plan was suitably amended on September 2, 1981 (Ordinance No. 152218).

PDC proposed that a citizens committee be appointed to pick the next developer. Although the Planning Commission argued that it should be involved in the selection process, perhaps jointly meeting with PDC, the Development Commission deftly sidestepped this issue by appointing the chair of the Planning Commission, Joan $\mathrm{H}$. Smith to the committee. As Joan Smith herself puts it, she is female, had experience with the successful Fountain Plaza project developer selection process, and is a team player. Each member of the selection committee represented different interests or talents - 
Joan Smith, the chair of the Planning Commission; Patrick $L$. LaCrosse, Executive Director of PDC; Robert F Franz, president of Pacwest Bancorp; architect Jon R. Schleuning, Partner, SRG Partnership; and most importantly, William E. Roberts, Chair of the Portland Development Commission. All decisions were by consensus with four of the members working to reach agreement with the fifth and most powerful, Bill Roberts. Bill had built the new Transit Mall and Pioneer Square, a new open space for the retail core. Both Bill Roberts and Mayor Frank Ivancie were "bricks-and-mortar" men.

PDC received four proposals in the fall of 1982 after national publicity. PDC selected three finalists: The Rouse Company of Columbia, Maryland; Williams Realty Corporation of Tulsa, Oklahoma; and Wright Runstadt of Seattle, Washington. ZGF, Soderstrom and BOOR/A represented local architecture firms. All other principles were from out of town. ${ }^{31}$ Bill Roberts noted that economic viability would probably be the biggest factor in the selection process. ${ }^{32}$ It was. The memorandum to PDC from the Selection Advisory Committee noted that "relatively little public discussion has focused on the dramatic or subtle differences in experience and abilities of the development teams to attract key shops, finance, build and operate a major retail project in a central downtown setting" but that this was a crucial consideration.

\section{Selection}

The Selection Advisory Committee selected Rouse. The three principal reasons for selection of Rouse were team qualifications, project economics, and retail identity concept design. The 
Committee voted for Rouse because it was voting for retail expertise and deep pockets: "other proposals, while visually exciting, are overly ambitious, perhaps to the detriment of the retail component."33 Only the Rouse Company team focused on retail and then sometimes added hotel or office space. The others did not have Rouse's ties with Batus, parent company of Saks and Frederick \& Nelson. Rouse included a letter from Batus evincing interest in the Portland project in its request for qualifications submittal (Batus Retail Division to Rouse, dated April 3, 1983.)

Most architects and architectural critics favored the Wright Runstadt proposal. While the Portland Chapter of the AIA selected Wright Runstadt, and only one Design Committee member voted for Rouse, conceptual design mattered only 25 percent. Project economics and retail concept favored Rouse. The City's economic advisor, Keyser Marston Associates Incorporated, recommended Rouse. Even Rouse's critics conceded Rouse's superior retail experience. ${ }^{34}$ Bill Roberts knew of Rouse's reputation through his previous retail experience. Rouse's glossy promotional brochure noted that it operated "over 100 major department stores and more than 5,200 individual stores, shops and restaurants in 31 million square feet of space." The 1982 Annual Report noted that 1982 earnings were up 45 percent to $\$ 23,784,000$. Bill Roberts distrusted its competitors, mostly suburban-oriented firms.

On June 30, 1983 PDC authorized negotiations with Rouse to commence over the next four to six months. The Commission also 
approved Saks Fifth Avenue and Frederick \& Nelson as retail anchors. Rouse proposed a three-block, mixed-use project to consist of:

- two department stores totaling approximately 200,000 square feet gross leasable floor area (GLA) on Block 50 (between SW Third and Fourth Avenues and SW Morrison and Yamhill Streets) and Block 60 (between SW Fourth and Fifth Avenues and SW Yamhill and Taylor Streets);

- specialty retail shops totaling approximately 155,000 square foot GLA located below grade on all three blocks and above grade within a two-story pavilion on Block 61 (between SW Fourth and Fifth Avenues and SW Morrison and Yamhill Streets);

- a 400 room, 25-story hotel and related facilities totaling approximately 340,000 square feet gross building area (GBA) located on Block 50;

- a 22-story office building totaling up to 350,000 square feet located on block 60 .

The project would build two levels of underground parking and retail prior to the hotel and office construction. Preliminary work required as part of light rail construction would accommodate the two levels. City approvals were quickly forthcoming. The Planning Commission and Design Commission split on the issue of skybridges but the Council approved skybridges with conditions. One skybridge would be two-levels.35 The Hearings Officer approved 1,024 parking spaces. 


\section{Re-negotiation}

Through 1985, the Rouse Company searched for tenants. In July, 1985, PDC announced a six month delay. ${ }^{36}$ Despite the delay, Council approved a $\$ 35$ million economic development bond issue on September 10, 1985.37 Rouse did announce an additional 30,000 square feet of specialty retail space and an Oregon Investment Council loan of $\$ 135-150$ million was secured. 38 However, Frederick \& Nelson bowed out on January 9, 1986 despite a letter of intent. And Rouse failed to land Siouffer as hotelier. ${ }^{39}$ The Oregon Investment Council withdrew $\$ 40$ million from its loan to the project.

The four blocks were now vacant without a replacement in hand. The retail core was suffering and local retailers were restive. Burnett Jewelers, Looking Glass Books, Golden Optical, and Dave's Deli considered suing the city. 40 These were a few of the 30 ground floor retail uses and 56 offices displaced and not yet relocated. 41 The June 25, 1986 deadline for negotiations had to be extended for three months.

PDC had known since early 1986 that neither Frederick \& Nelson nor a hotel would be part of the first phase of the Morrison Street Project. Rouse had proposed to limit its financial liability by dropping the second department store, the hotel, and underground parking (see Figure 26).42 At the March 19, 1986 Commission meeting, staff presented four options for proceeding with the Morrison Street Project ${ }^{43}$. The options included: 


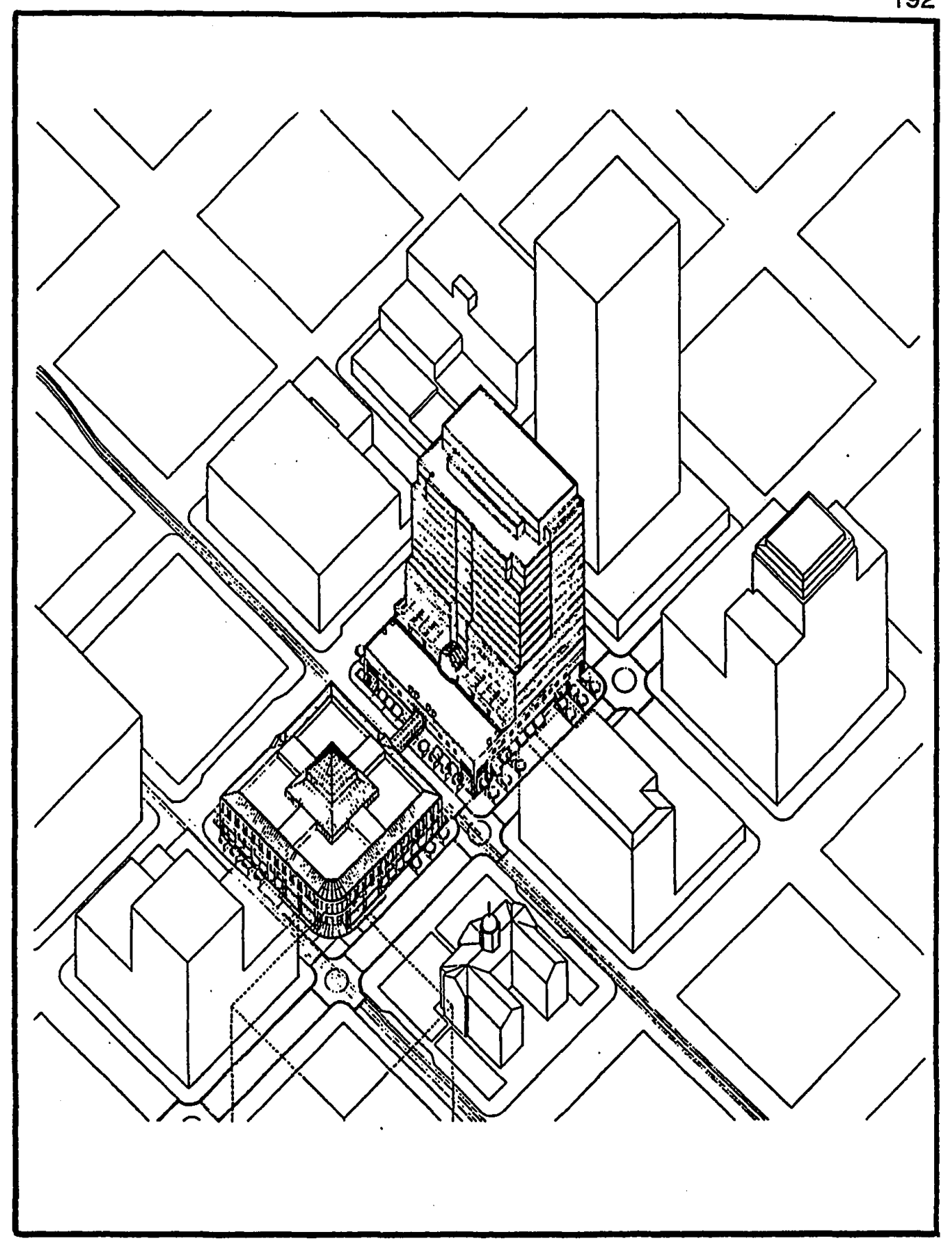

Figure 26. Revised Pioneer Place Concept Proposal. From Rouse-Portland Proposal (1987). 
Option 1: Place the project on hold until all major components could be delivered. Not recommended by PDC staff.

Option 2: Develop those components of the project that could proceed on Blocks 60 and 61 (Saks, retail pavilion, office tower, subsurface parking) and reserve Block 50 for future development. PDC staff rated this option acceptable.

Option 3: Develop all three blocks at once with ground-level retail activity and above-grade parking on Block 50. A second future office tower could be incorporated into this program, subject to securing a City FAR variance. Not recommended by PDC staff.

Option 4: Develop Blocks 60 and 61 with Saks, the retail pavilion and office tower and locate the parking in an above-grade structure on Block 51. Acceptable to PDC, Rouse's preference.

While PDC wanted Saks, the retail pavilion, and the office tower with below or above-grade parking (Options 2 and/or 4) Rouse "preferred" above-grade parking but would "pursue" parking belowgrade. After two executive sessions in May the Development Commission told Rouse that the project's main goal was to maximize retail development and that all design, program, financial and that timeframe decisions should be made from this perspective.

The Selection Advisory Committee was called to review the issue purely on a "rubber stamp" basis, according to one of its members. The Selection Advisory Committee no longer had real authority; this was a pro forma presentation. The Selection Advisory Committee saw a brief presentation of a few boards with the "good news, then the bad news"approach. 44 
At the September 15, 1986 PDC hearing Rouse proposed a fourblock, two-phased project to include:

Blocks 60 and 61: 135,000 square feet of retail, including a glass pavilion on Block 61 containing 70-100 specialty stores;

Block 60: a two-level, 60,000 square foot Saks Fifth Avenue as retail anchor, along with a 18-story office tower;

Block 51: An 8-story, 600-675 space public shopper garage on the northern $3 / 4$ of the block; 14,000 square feet of ground floor retail would be master-leased to Rouse.

Block 50- reserved for future development of the second retail anchor and hotel or office tower.

Cost of the project's first phase was estimated at $\$ 120$ million with a total public/private investment of $\$ 180$ million completed. 45

PDC approved the redesigned project on October 9, 1986 and the City Council allocated $\$ 12.7$ million to build the above ground parking garage on December 12, 1986. ( $\$ 3$ million was paid by Rouse.) 46 According to the Oregonian, the consensus on the street from downtown retailers, real estate brokers and politicians was that the company and PDC had "salvaged a decent, albeit incomplete, version of the original development plan approved three years ago, but which has since proven economically unfeasible for a variety of reasons." 47 Bill Roberts - who knew when and how to close a deal had picked Don Magnussen, a banker, to succeed him as chair of the Development Commission. Roberts supported the redesigned project. 
The switch from below-grade to above-grade parking remains one of the most controversial decisions from 1986. Several observers considered this unnecessary. This decision would line the SW Third/SW Fourth corridor, from SW Washington through SW Salmon, with surface parking lots and parking structures. This could be compared to a hole in the donut. The retail core could end up mostly parking space.

Not all observers thought that Rouse's and PDC's excuses were legitimate. Rouse perhaps refused to build 800 underground spaces, and made an ultimatum to the City. Observers discount Rouse's excuses of escalating project costs, construction problems (poor soils and a sloping site), and marketing issues such as public aversion to below ground parking. (Several sources alleged that the Rouse Company had promised a hotel aware that there was no market.) Simultaneously, the Rouse Company was renegotiating in Seattle for concessions. Willamette Week quoted David Soderstrom, a former chair of the Design Commission that "Rouse purposely promises more than it can deliver in order to win development projects. That's been Rouse's style on its last four or five projects. They wait for the city to run out of patience and then build whatever they want." 48 The AlA called this a reversal of the decision-making process.49 PDC replied that an amendment to Waterfront Urban

Renewal Plan was required, which allowed for full public discussion. The City was forced to trade long-term benefit - private development and tax revenues on a block adjacent to Pioneer Place for a one-time compromise payment from Rouse of $\$ 3,000,000$ to 
not build 175 units of underground parking. The Oregonian

editorialized for approval of the revised project, pointing out that it would serve the Yamhill Market retail project, a former PDC project in the Yamhill District.50 The irony of this reference is that Pioneer Place would compete with a failing Yamhill Market. Despite the setbacks, Batus/Saks approved their participation and the Rouse board approved the project. The State of Oregon Employee's Pension Fund granted a 35 year variable rate $\$ 110.5$ million loan to Rouse 51 . This represented 96 percent of the project's cost.52 PDC received Design Commission approval of the revised project on July 2, 1987. The project was described as a mixed-use project containing 174,000 square feet of specialty retail, a 60,000 square foot department store and a 16-story 329,000 square foot office tower.

The project survived two court challenges. An owner of part of the site sued simply to receive more cash in settlement for the public taking. A tax activist unsuccessfully tried to block the project. Tom Dennehey charged that PDC had been "illegally" collecting tax increment revenue over the previous six years $(\$ 77$ million). None of the previous activists were involved.

Determining value for condemned property represents the typical jousting over compensation for government takings. The latter case reflected Dennehey's view that PDC unfairly warped the property tax system in favor of downtown interests. 53 Tax increment financing raises the level of taxes paid outside the district for a specific period of time walling off revenue that can be 
used for general governmental purposes. Tax increment financed projects are not put to a vote of the citizenry.

OPD anticipated $\$ 1,915,000$ in annual tax revenue (1985 dollars) in return for a public investment of $\$ 19.5$ million (1988 dollars). Two thousand jobs would be created. The Corbett building was demolished in a spectacular implosion and construction began in early 1988.54

\section{OPENING}

The project opened on a beautiful spring day, March 29,1990. The Sunday Oregonian published a promotional section. The newspaper trumpeted:

Class \& Sass, Pioneer Place mall mixes elegance with a little whimsy."

Upscale but small-scale. New yet old. Fun but not trendy. Fitting in but standing out.

But Laurin Askew, project design director, and other observers believe most of those wishes are fulfilled in the final product that opens Thursday....

"Portland has a nice quality about it; it has a very human scale to it." Askew said. In designing the retail pavilion, "the trick was to find a building that was crisp and modern in its approach, yet lived without becoming 'ye olde.."'

'It's one of our best projects in terms of architecture, quality and materials," said Perry Page, vice president in charge of West Coast project for the Rouse Company, parent of RousePortland Inc., developer of Pioneer Place. 
"It has a very special sense and quality to it. It's as good as anything we've done anywhere in the country, as good as anything anybody has done anywhere."

PDC expressed satisfaction. PDC project coordinator Chris Kopca stated that: "It's everything we could've hoped for. It's proven worth the wait." Pat LaCrosse acknowledged that the city "did not get quite what we hoped for when we started out. But I feel very satisfied with what we have, knowing we came close to not having anything at all." LaCrosse credited Rouse with going "the extra five miles." Rouse predicted that between four million and six million shoppers would visit Pioneer Place annually. Sales should average close to $\$ 400$ a square foot, about the same as Westlake Center. Rents were climbing in shops in the vicinity, too.55

Of the 29 tenants tracked by the Oregonian, 19 were still in business in March, 1990. PDC spent $\$ 468,000$ in relocation assistance to help relocate 27 retailers and 41 office tenants. Seventy percent of this money went to the retail firms. Twenty one businesses had been invited back to the pavilion but none could afford the rent. Only nine of 51 Pioneer Place retailers were Oregon-based. Rouse's tenant mix is tilted toward national brands. 56

Furthermore, all the big projects - the Transit Mall, light rail, Rouse - disrupted retailing during construction. PDC disregarded the opportunity to relocate the small retailers to Yamhill Market, a city-funded project only two blocks away. Nurturing small retailers was not city policy. As the small retailer was a pawn in the Cadillac-Fairview controversy, so were the Corbett and Goodnough 
buildings. Historic preservationists no longer argued to save these buildings once it was clear that they were in conflict with Rouse's design plans.

\section{CONCLUSION}

This ten year process of conflict and resolution provides a clear view of Portland's urban regime and its incorporation of influentials' concerns into its urban renewal mechanism. Figure 27 illustrates how the urban regime handled opposition, the degree of community agreement on the need for the project, and whether activists challenged at the ballot box.

At first, the regime proved unskilled in dealing with the demands of citizen activists and the unforeseen objections of realtors. The Downtown Plan called for a compact retail core extending to the river and counted the loss of the Lownsdale residential community as the price of a revitalized metropolitan core. The plan hoped to replace the Lownsdale residential community with a bridgehead redevelopment project and did not propose anything special for the four blocks bounded by SW Morrison and SW Taylor from SW Third to SW Fifth. The plan could not foresee the national trend to build urban versions of the regional shopping mall as the means to downtown revitalization. The Portland Development Commission, under activist Mayor Neil Goldschmidt, put out feelers at a national Urban Land Institute meeting and attracted an international developer without local public discussion. The announcement caught the local pro-growth regime by surprise. The 


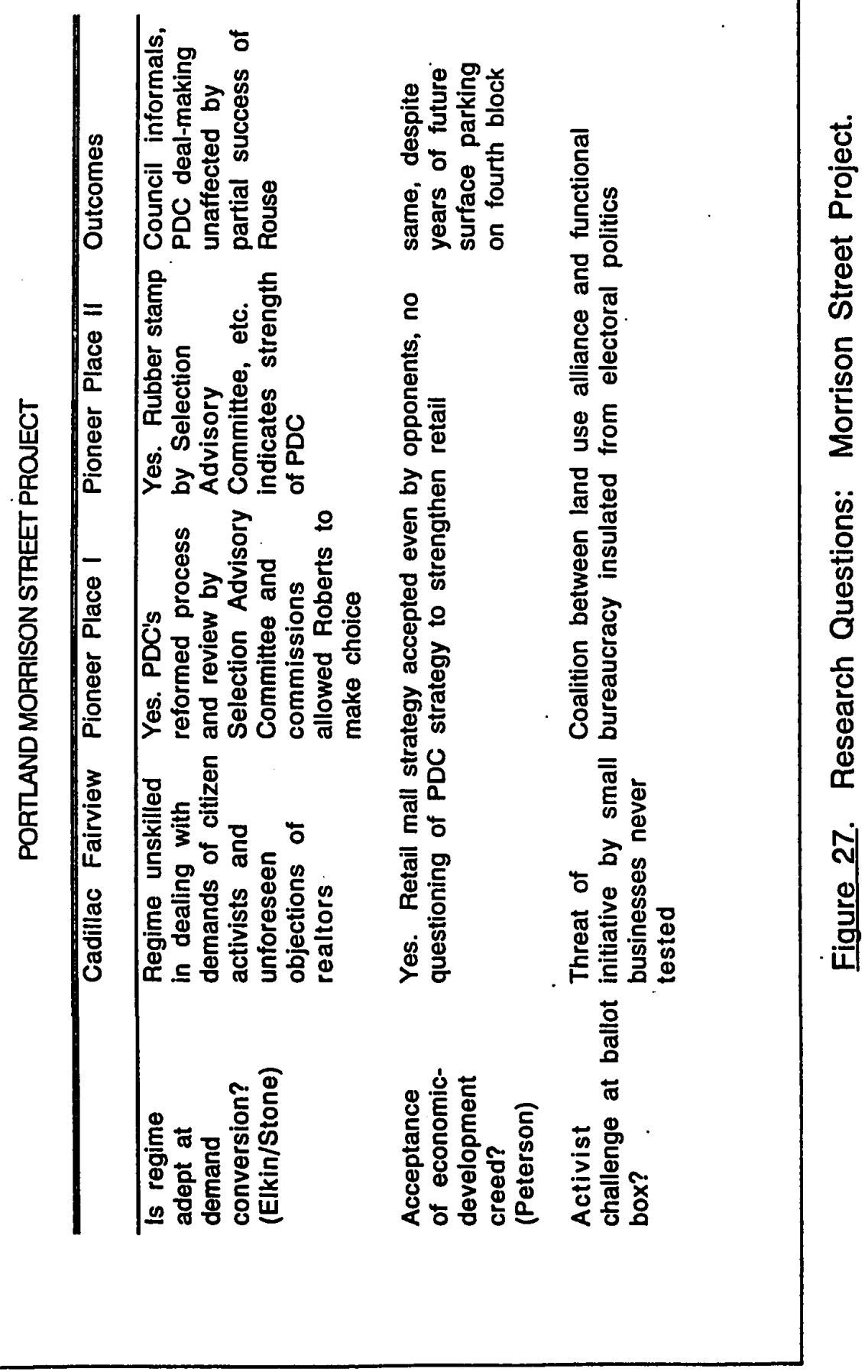


chief benefit of growth is profit to investors and it appeared as if locals would not benefit. Land assembly, land price write-downs, consultant fees, and other public subsidies would not be available to local investors and professional firms. The resulting split in the business community allowed an unusual amount of criticism to surface. Those major property owners expecting to profit supported the project. Neighborhood activists who had helped create the Downtown Plan were ambivalent. Housing activists, historic preservationists, and urban design aficionados opposed the project or sought modifications. Under siege, the developers brought in local influential professionals such as attorney Steve Janik and architect Bob Frasca to meet the demands of the moderates. However, a small group of displacees - Vietnam era radicals who had prospered as small businessmen - mobilized. Ultimately, these small business people had no greater success than residents and businesses displaced in the South Auditorium era. Council still approved the project (with design modifications to satisfy the former group and relocation sweeteners to appease the latter).

The retail mall strategy was accepted even by opponents. The question was one of means rather than ends of this widely accepted economic development strategy. The underlying policy of rescuing the retail core was paramount. The institutional weight of OPD and PDC's support and the City's sense of urgency cannot be overestimated. Still, whether it was weak economic times or a dispute over the amount of retail space within the skybridges, the project collapsed. 
The small merchants' threat to put an initiative on the ballot never materialized. Although they reacted to the threat of displacement to an unprecedented degree, no lasting political organization came of the controversy. Interestingly, Tom Dennehey's suit foreshadowed a state-wide tax revolt which will not be determined until the summer and fall of 1993 when Oregon voters will be asked to exempt tax increment financing from a property tax limitation. Unlike Seattle, relations between opponents remained cordial. Housing displacement and loss of small businesses were not blamed generally on downtown growth. On the contrary, the experience validated the need for a commercial retail core project. PDC staged a careful public process which came closest of all six case studies in reaching deep into the community. But these public hearings involved members in good standing with the urban regime. The urban regime coalesced in pursuit of the project once the realtors' objections were met. The City made a fundamental shift to an urban renewal program based upon multiple public policies put in place prior to the developer selection process. But the city pursued the same goal as before - luring an national retailer at the expense of other competing users of this central space. The demands of small local retailers were less important than the chance to regain dominance in the regional upscale retail scene.

The adoption of public objectives was an open process, but the selection of Rouse was decided by Bill Roberts. Roberts, a successful retailer, downtown property owner and chairman of PDC, had no peer. The selection committee, itself restricted to important 
urban regime members, deferred to Roberts' judgment. Negotiations with Rouse were negotiations between PDC/Roberts and Rouse. Whether Rouse unfairly re-negotiated in the crisis summer of 1985 is difficult to determine. The city was in a great bind having moved tenants out in the previous months and having created a rather large four block hole. The crisis was not time to rethink the public interest. The Selection Advisory Committee was in place to maintain appearances of the regime's continued adherence to the Request for Proposal's public intentions.

The City succeeded in redeveloping three and one-half blocks and spurred a successful revitalization of the retail core in the immediate vicinity. This came at the expense of tenants and retailers located more than a block away from the nine blocks surrounding the project. Downtown retail no longer provides a full range of comparison goods for a diminishing residential community. 57 The project still has one full block to redevelop. The block will be difficult to develop and is being used for surface parking. The project does not fulfill the Plan's initial goal of extending the retail core to the river. In fact, the public has forgotten this goal. The project has helped to kill Yamhill Market, another tax increment financed project in the Yamhill historic district. The public's patience with a new surface parking lot in the center of the city is a measure of the City's reliance upon PDC to implement a traditional economic development strategy. 


\section{ENDNOTES}

1PDC Resolution 2680, March, 1979.

${ }^{2}$ Bureau of Planning, Planning Guidelines, Downtown Plan, "Retail Core," p. 54.

${ }^{3}$ The Urban Renewal Plan for the Downtown Waterfront Urban Renewal Project was first adopted by Council on April 25, 1974 by Resolution 31395. 1979.

${ }^{4}$ Oregonian. "Money-makers: Zipped lips may tip off something big," March 11 ,

5 Journal, "Developer: Mall 'gives edge to downtown," March 21, 1979.

Oregonian, "Firms optimistic on four block development," March 21, 1979.

Qregonian, "Plan may top off city's downtown design," March 25, 1979.

6 Mark Clemons, "Public Issues in the Urban Renewal Process, A Case Study of the Morrison Street Development Project, Portland, Oregon 1979 - 1984, p. 9.

Portland Development Commission, "Proposed Morrison Street Downtown Development," July 17, 1979.

Lyle A. Stewart, "Report on the Existing Conditions within Blocks 50, 57, 60 and 61, June 27, 1979.

${ }^{7}$ Oregonian, "Four block development surprises merchants," March 21, 1979.

Journal, "Downtown Plan pits people vs. progress," March 19, 1979.

Willamette Weak, "The Cadillacing of Downtown," June 11, 1979.

${ }^{8}$ Journal, "Downtown plan pits people vs. progress," April 19, 1979.

9 Journal, "City's close ties with developer questioned," May 4, 1979.

${ }^{10}$ Oregonian, "PDC ponders Cadillac project," May 9, 1979.

11Porland, Development Commission, staff, "Background Paper, PDC and the Morrison Street Downtown Development Project," November 1979.

${ }^{12}$ Oregonian, Cadillac project modifled to match downtown mood," June 13, 1979.

Oregonian. "Design issues haunt Cadillac plans," July 20, 1979.

${ }^{13}$ Oregonian, "Development panel eyes resolution on 'superplan' " July 16, 1979.

Oregonian, "Canadian firm wins PDC OK," July 18, 1979.

14 Journal, "Cadillac Fairview go home!'," August 7, 1979. 
${ }^{15}$ Oregonian, McCready rekindles Cadillac Fairview Plan," September 6, 1979.

Oregonian, "McCready lends support," December 8, 1979.

${ }^{16}$ The approval was contained within the PDC report, "Analysis of Cadillac Faiview proposal for a Morrison Street Downtown Development," July 1979.

17 Journal, "Big Downtown project needs major change," December 7, 1979.

${ }^{18}$ Oregonian "Clity report supports Downtown complex," December 8, 1979.

${ }^{19}$ Oregonian, "Cadillac proposal blasted at hearing," December 20, 1979.

${ }^{20}$ Oregonian, "Council questions California experts on Cadillac Fairview," January 4, 1980

${ }^{21}$ Willamette Week. "Architectural suggestions for Cadillac Fairview (John Yeon)," January 21, 1980.

${ }^{22}$ Oregonian, "Council vote on Cadillac Fairview put off," January 24, 1980.

Qregonian, "Cadillac proposal wins tentative ok from Council," January 31, 1981.

${ }^{23}$ Oregonian, "Merchants take Cadillac Fairview to court," February 21, 1980.

Oregonian, "Cadillac critics say officials acted illegally," March 11, 1980.

Oregonian, "Merchants lose 2nd round with developers," March 15, 1980.

Journal, "Cadillac Fairview foe confident of win," April 11, 1980.

${ }^{24}$ Ed Tenny, interview, May 6, 1992. Journal, "Cadillac Fairview opposition gains momentum," May 2, 1980.

25 Journal, "Cadillac Fairview seeks more time to deal," May 6, 1980.

Oregonian, "Cadillac Fairview reveals new snag," May 7, 1980.

Journal, "Cadillac Fairview not victim of times," May 20, 1980.

Journal, "Cadillac Fairviow ouster opens doors to others," June 6, 1980.

Oregenian, "Cadillac Fairview proposal dead," June 6, 1980.

${ }^{26}$ Oregenlan, " 'Development project' " awaits council's judgement call," October 7 , 1980.

27Portland Development Commission, "Action Plan for Downtown Retail Development in Portland, Oregon, Final Recommendations for the Morrison Street Project," June 1981.

${ }^{28}$ The Gilbert block/Taylor Hotel was no longer within the project area. 
${ }^{29}$ Oregonian, "\$12 million dollars allotted for Cadillac-Fairvlew," February 3, 1981.

Oregonian, "PDC study asks minimum size on new project," April 8, 1981.

${ }^{30}$ City Council Resolution 32958 passed second reading July 16, 1981.

Oregonian, "Morrison project passes Council with little dissent," July 17, 1981.

${ }^{31}$ Oregonian, "Three enter Portland competition," October 13, 1982.

${ }^{32}$ Oregonian, "Retail mall plans rated neck and neck" May 6, 1983.

${ }^{33}$ Morrison Street Project Developer Selection Advisory Committee, "Memorandum to PDC," June 21, 1983. Oregonian, "Midsize' plan favored for Morrison project," June 9, 1983.

${ }^{34}$ Alan Hayakawa, "Designer's approaches to Morrison Street Project vary widely," June 19, 1983.

${ }^{35}$ Oregonian, "Panel approves 3 skybridges for Morrison Street project," October 10, 1984.

Oregonian. "Panel opposes Morrison skybridge plan," November 24,1984.

Qregonian. "Developer willing to pare skybridges, November 26, 1984 (City Council approved 3 skybridges with restrictions on December 5, 1984).

${ }^{36}$ Oregonian "Snags may delay Morrison project for 6 months," July 20, 1985.

${ }^{37}$ Oregonian. "Bond issue for Morrison project gets preliminary council OK," October 10. 1985.

${ }^{38}$ Oregenian. "Retail space added to Morrison project," November 5, 1985.

${ }^{39}$ Oregenlan, "Hotel dropped from Pioneer Place," March 14, 1986.

${ }^{40}$ Qregonian, "Downtown retailers painfully await project," March 31, 1986.

41PDC, "Action Plan for Downtown Retall Development in Portland, Oregon, Final Recommendation for the Morrison Street Project," p. 20.

42Oregonian, "Developer says snags unexpected," March 20, 1986.

Oregenian, "High-rise garage eyed," March 20, 1986.

Oregonian, "Morrison project sinks in scale, raising issue," March 30, 1986.

Oregonian, "Morrison project snag follows great year for Rouse," March 31, 1986.

43Patrick L. LaCrosse, "Memorandum to the Commissioners, Morrison Street Project Review of Alternatives and Providing Direction to the Rouse Company," June 19,1986. 
${ }^{44}$ Oregonian, "Morrison plan parking rapped," April 2, 1986.

Willamette Week, "What's wrong with Rouse?," April 9, 1986.

${ }^{45}$ Oregonian, "Expand MP developer says," May 7, 1986.

460regenian, "Redesigned Pioneer Place clears hurdle," October 9, 1986.

${ }^{47}$ Qregonian, "Rouse Plan receives favorable reviews." September 16,1986.

48 Oregonian, "Developer says snags unexpected," March 20, 1986.

Willamette Week, "What's wrong with Rouse?" April 3 - April 9, 1986.

${ }^{49}$ Alan Hayakawa, "Rouse parking should be underground," October 8, 1986.

${ }^{50}$ Oregonian editorial, "A Rouse-ing welcome," September 18, 1986.

${ }^{51}$ Oregonian, "Council votes to add parking structure," December 12, 1986.

${ }^{52}$ Oregonian, "Rouse gets downtown project loan." May 5, 1987.

${ }^{53}$ Oregonian, "UR Ruling slaps city," August 3, 1987.

Qregonian, "Way cleared for Pioneer Place project," December 10, 1987.

${ }^{54}$ Oregonian, "Block in Pioneer Place site rich in history," November 16, 1987.

55 Oregenian, "Pioneer Place arrives - at last and in style." March 25, 1990.

${ }^{56}$ Oregonian, "Pavilion lacks Oregonian retailers," March, 25, 1990.Oregonian, "Make way for Progress," March 25, 1990.

57 Meier \& Frank department store is the last full-line department store downtown. It does carry housewares, electronics and furniture in addition to clothing. 


\section{CHAPTER VI}

\section{SEATTLE WESTLAKE MALL PROJECT}

The vital point is that our cities must be gradually reordered and restructured so that each part will contribute toward intensifying the lives of those who live in them.

\section{Fred Bassetti ${ }^{1}$}

\section{EARLYSTRUGGLES}

The 1965 Comprehensive Plan for the central business district envisioned a series of pedestrian malls on Westlake, Pike, Pine and Fifth Avenues connecting with a redeveloped Pike Place Market, a new Market Park, and the redeveloped Waterfront. Although a symbol of progress, the monorail built for the World's Fair cast a shadow over the Westlake right-of-way and divided the retail core centered on Westlake and Pine.

In 1968, Forward Thrust bond moneys became available to provide solutions for the acknowledged lack of downtown "sit-in parks." Of the $\$ 118,000,000$ bond issuance, $\$ 1,750,000$ was earmarked for the "acquisition of several small sites in the central business district."2 In November, 1968, representatives of Mayor Wes Uhlman's office, the City Council, the City Planning staff and the Central Business Association met to discuss downtown park improvements. Perhaps influenced by an American Institute of Architects (AIA) proposal, ${ }^{3}$ the Cultural and Beautification 
Committee of the Central Business Association recommended that the Forward Thrust funds budgeted for downtown be concentrated on one or two major projects with maximum impact, and that one of these projects be full development of Westlake Mall as a principal downtown focal point at a cost of $\$ 1$ million. The AIA began a twenty-year process by proposing that Westlake between Pike and Olive, Pine Street between Fourth and Fifth, and Fourth Avenue between Pike and Olive be closed and incorporated into a major open space adjacent to complementary retail space. Fred Bassetti was chair of the AlA subcommittee which produced the proposal. The accompanying diagram indicated a large circular open space surrounded by the Bon Marche department store to the northwest, a new monorail terminus to the north, Weisfields jewelers to the northeast, and Nordstrom department store to the south. A new building to the southwest was also indicated.

In 1969, the Central Business Association and the City of Seattle jointly contracted with Fred Bassetti to design a project for Westlake. The Westlake planning area was considered to be Olive on the north, 6th Avenue on the east, Pike on the south, and 3rd on the west and Westlake on the east. Bassetti proposed closing parts of Fourth Avenue and Pine Street in order to create a roomy plaza and a tightly-woven system of shops, offices and a hotel perched over an underground parking garage. By this time, the Central Association had withdrawn its support from the $\$ 270,000$ study. The Central Association withdrew its support when the Bon Marche's James Walsh became president. Walsh was opposed to closing any streets. 
Closure of Pine would cut off direct access to the Bon Marche department store down Pine from the 1-5 freeway (see Figure 28). Also, Bassetti's opposition to plans to raze Pike Street produce market put him at odds with the downtown business establishment. ${ }^{4}$. Bassetti's next design was a stretch of shops beneath the monorail. Bassetti's other client, the City Parks Department, vetoed this use since it would mean spending public money without creating new open space. The third design was also doomed. It avoided placing structures in the alignment of Pine Street, pushing the monorail terminal to the north and shops to the south of Pine. Although closing Pine Street to cars but not to buses was intended as a compromise, Walsh remained opposed. The City could not build in vacated alleys and streets without the acquiescence of the businessmen.

Mayor Wes Uhlman sought to garner public support by holding a public meeting on May 27, 1971. The meeting was a failure. According to the Argus, the meeting highlighted the lack of City Hall leadership, the opposition of the Bon Marche, the conflict between the downtown retail establishment and the Friends of the Market, lack of a business leader who "could stop the bickering," and the suspicious public long kept in the dark. The next day, Bassetti's contract was terminated. 5

The following year, Allied Arts, an influential civic betterment organization, progressive CHECC politicians, and property owners got the process moving again by hosting a talk by 


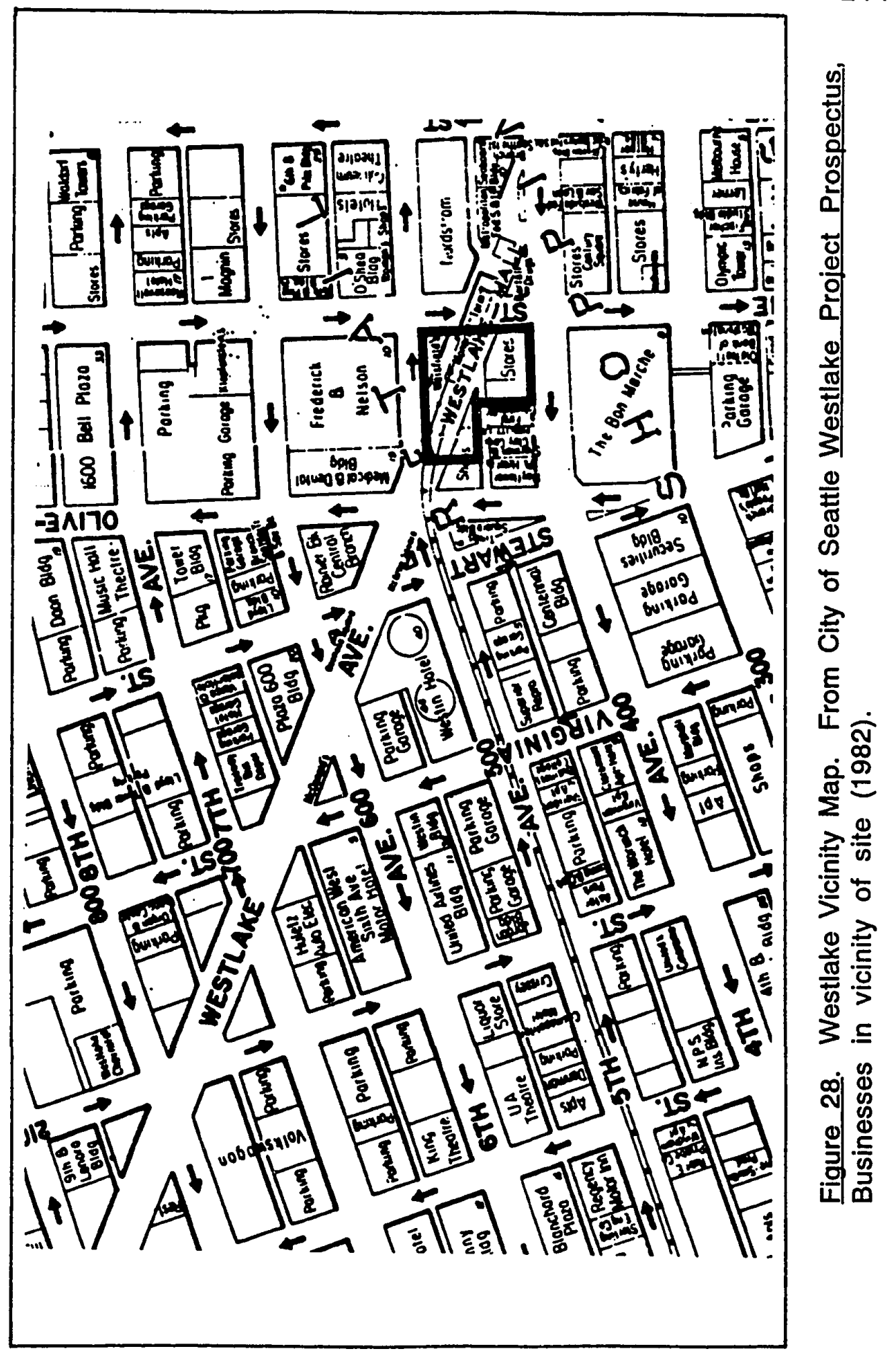


visiting architect Archibald C. Rogers on successful redevelopment in Cincinnati. In June, 1972, Mayor Uhlman named a 12-member

Westlake Advisory Committee to act as a public forum for discussing the issues and resolving conflicts. According to a later City of Seattle EIS statement, the Advisory Committee determined "that it would not be economically feasible to expect private concerns to finance all of the desirable redevelopment other than that intended for park use." The April, 1973, Committee proposal was significantly more profit-oriented than the development of Westlake Park. Two components were proposed - a spatially distinct market and a large public space of 50,000 square feet. Both Westlake and Pine would have to be vacated. The Committee thought that public and private interests should merge.6 To quote from the report to the Mayor:

A project to achieve these goals in the Westlake area can be accomplished only by a cooperative effort of City and private interests. Not only will retail goals be defeated if the public space is designed so that it impairs the retail function, but proper design and development of surrounding commercial structures is essential to success of the public space. Since each aspect of the project should not only not detract but enhance the other's function, any project in the area must be jointly designed and accomplished.7

The Committee proposed a core project which would redevelop a portion of the block between 4th and 5th Avenues and Olive and Pike Streets to provide a public space on the second floor of a commercial mega-structure. The space was roughly equal in area to the existing Westlake right-of-way being vacated. The committee 
rationalized adding commercial space as providing "both an economic return and necessary retail density and amenity, and an appropriate setting for the public space."

The Council authorized $\$ 60,000$ for economic and architectural studies. The Westlake Advisory Committee directed a City management team. Coldwell Banker did the retail market analysis and found the downtown to be distressed and in need of such a project. 8 Naramore, Bain, Brady and Johanson and Fred Bassetti did the architectural study. These firms had participated in the previous decision to build more shopping center rather than park. The new "Westlake Park Feasibility Study" proposed 36,000 square feet of retail space surrounding a 7,000 square foot glass atrium, new monorail terminal, and skybridge connections to surrounding department stores. "Public space" was again located one story above surrounding public sidewalks. Pine Street was to remain open (see Figure 29). 9

The Parks and Recreation Department proposed to fund the project with $\$ 983,000$ in Forward Thrust funds and an additional $\$ 8$ million of Councilmanic Bond Funds. The Final Environmental Impact Statement (EIS) was published in May, 1975. Public investment was expected to leverage a $\$ 27$ million dollar redevelopment effort in the area. 10 The project faced opposition from two sides. Small property owners objected to the large expenditure of public funds, the demolition of existing buildings, and displacement of a variety of small business tenants such as the Mayflower Hotel, Sherman \& Clay Music and Bartell Drugs. ${ }^{11}$ These property owners threatened 


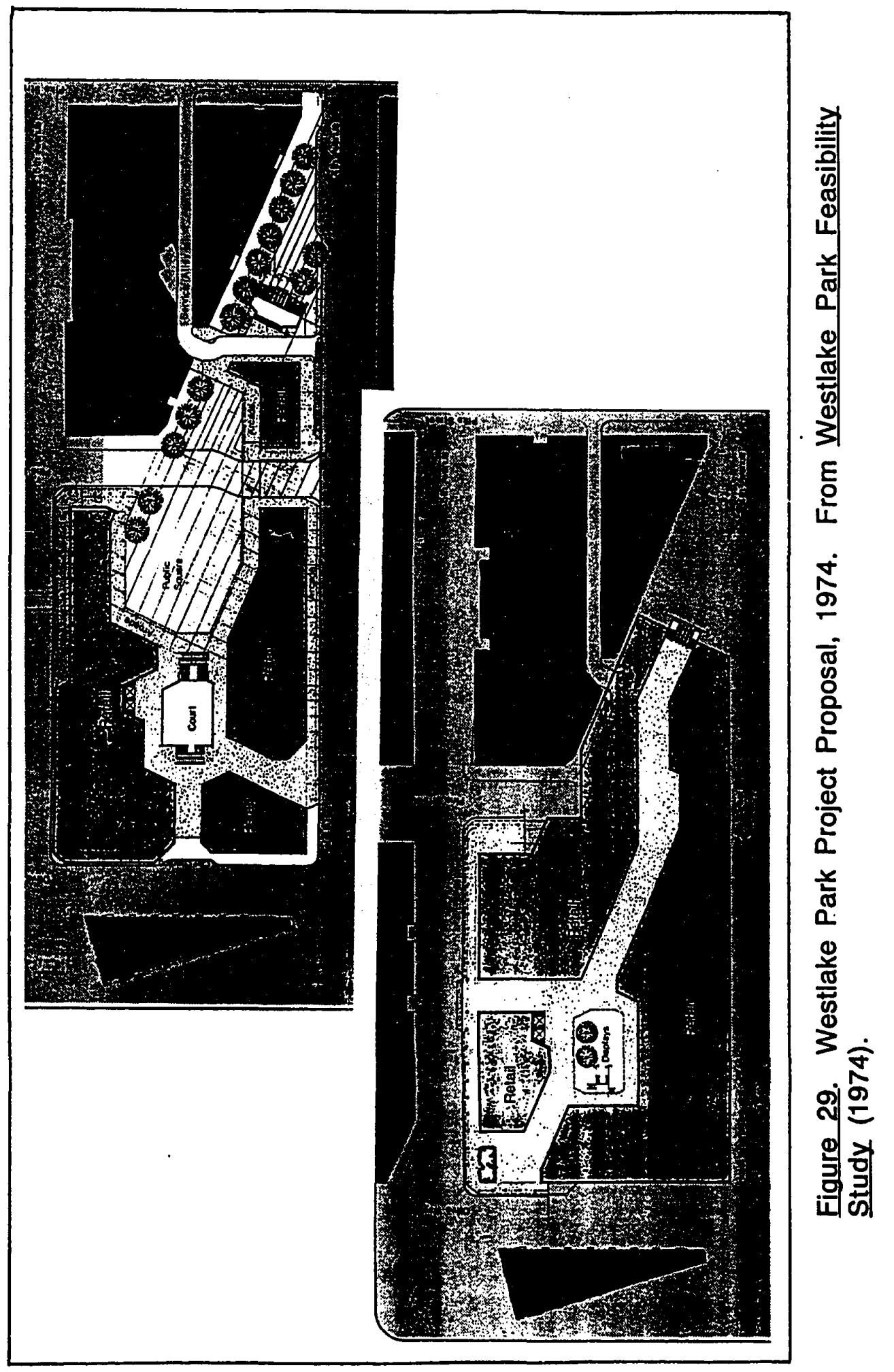


litigation. Large private investors would not assent to a project conceived and developed by the City alone. The City dropped the project again. On August 11, 1975, the Council passed Ordinance 104797. This ordinance authorized

the Director of Community Development, with advice from the Superintendent of Parks and Recreation to prepare or cause to be prepared through contracts with expert consultants, a proposal for the Westlake Project ... to provide an aesthetically satisfying urban park of appropriate scale to strengthen the retail core of the City's Central Business District and of a size approximately equal to the existing right-of-way of Westlake Avenue between 4th and 5th Avenues, including a proposal and recommendations for appropriate contiguous private commercial development to enhance such park to achieve establishment of a downtown focal point...

The City issued a prospectus inviting developers to submit proposals based upon the goals of the Westlake Advisory Committee. Criteria for selection included (a) development experience, (b) qualifications of the architect, (c) qualifications of the principal staff on the project, (d) capability to finance the project, (e) experience in leasing and management, $(f)$ proposed ownership role in completed project, and (g) proposed scope of work and timing. 12

\section{MONDEV}

In December, 1975, the City selected Mondev International of Montreal. Architects were Mitchell-Giurgola of New York and Joyce, Copeland, Vaughn and Nordfors of Seattle. Mondev beat out CadillacFairview of Toronto who would propose the ill-fated venture in Portland a few years later. ${ }^{13}$ The famous urbanist, Edmund Bacon, 
consulting for Mondev, promised new energy for the core and at the same time new open space by demolishing the historic Bartell Drug store. Mondev made public presentations throughout the next year and delivered schematics to the Department of Community Development in October, 1976. The proposed project consisted of a 300 room hotel, retail shops, theaters and restaurants, two public plazas, malls, arcades, a parking garage, a public park and a new monorail terminal. The project expanded to incorporate the Times building to the north and sent development north toward Denny Regrade, the old psychological limit of downtown. As far as public open space, the proposed park became $\mathbf{4 0}$ percent smaller at a cost of $\$ 9.5$ million dollars. 14

\section{Opposition}

Proponents of the project included the Chamber of Commerce, the Downtown Seattle Development Association, Allied Arts, the League of Women Voters, and the two newspapers, the Seattle Times and the Seattle Post-Intelligencer. ${ }^{15}$ Opponents of the project included some of the $\mathbf{4 2}$ merchants likely to be dispossessed by the project and those who thought the project too large, too commercial and too privately-oriented with an inadequate public square. "Citizens and Merchants Against the Westlake Mall Project"16 appealed to the public at large to stop the downtown interests "juggernaut." 17 CHECC opposed the project because the City and the downtown business interests had turned a public square into a retail opportunity. CHECC's protest pamphlet summed up their argument: 
"The Park that Got Swallowed Up. Westlake Park, an Easy Catch for Big Fish Progress?"18

The architecture was admired by University of Washington professor Victor Steinbrueck who called it "very imaginative and intensely dynamic." Steinbrueck liked the architecture but disliked the principle of private interest advanced as public interest. Victor Steinbrueck's concerns had weight because as a University of Washington architecture professor he had led the fight to preserve Pioneer Square and had contributed to the preservation of Pike Street Market. His two books, Seattle Cityscape and Seattle Cityscape \#2, had provided a clear philosophical alternative to the big projects favored by the downtown urban regime.

With full recognition of the interest and excitement of the architectural plan and with due respect to the impressive stature of the professional persons and corporation involved, there need to be further concerns expressed and questions asked.

Perhaps the most important concern is raised by consideration of the relatively humble nature of the origins of the project; the Forward Thrust "small sit-in parks" proposition, the acorn from which this mighty oak has grown.

- Is it appropriate for the city to be responsible for, and in actual partnership with, private enterprise in developing a large-scale, commercial project as the focus of downtown?

- Is business itself a public amenity and therefore deserving of direct financial support? 
- What of the symbolism of the publicly advocated and planned focus of downtown as a commercial complex - in contrast to a public space to be enjoyed by all?

One might ask also if a private developer, however enlightened, ever can place the public interests above his own financial motivations (or are the public amenities being used to enhance a private project?) What is the public responsibility? What does the city pay for - and maintain? Should, or can, Seattle spend another $\$ 8$ or $\$ 9$ million on such a development which includes so much private benefit? Will the City Council buy it? Will the public buy it? ${ }^{19}$

Despite Steinbrueck's principled opposition and the opposition of those who faced condemnation of their property, the City Council unanimously approved the project following completion of the Environmental Impact Statement (EIS) on May 10, 1977. The Westlake Development Authority, chartered and appointed by Wes Uhlman in December, committed $\$ 10.8$ million in bonds to cover the city obligation. These bonds were not subject to voter approval.20

There were two significant roadblocks to the project. First, an outsider candidate might make this a downtown vs. neighborhood issue in the upcoming Mayoral race. Uhlman would not be running for another term. The second roadblock, alluded to by Victor Steinbrueck, was the legality of the council decision. At the time, the City supported State legislation, HB 1191, which would specifically authorize Westlake.21

\section{Royer's Revision}

Charles Royer, an Oregonian who had succeeded as a mildly controversial investigative newscaster in Seattle, ran as the 
neighborhoods' candidate. Royer made his opposition to Westlake a campaign issue in his race against Paul Schell, former head of the Seattle's Department of Community Development and proponent of the Mondev project. His campaign literature stated that he "would work to complete as Mayor, a smaller scale, downtown park which would stimulate and encourage private development at private cost." Royer agreed with Steinbrueck that the scale of the project was too large, that the park was clearly a secondary priority and that the project would price middle income business and middle income consumers out of downtown. Royer emphasized his opposition on principle:

There are serious constitutional and moral problems. The proposal depends on the lending of public credit to a private developer. And, for the lending of our credit, we are developing amenities which many of our citizens will not be able to afford. The shops proposed by MONDEV would be nice, but it is my guess that most of our citizens are not able to buy their clothes from Pierre Cardin. Most of our citizens should not then construct an outlet for Cardin's wares. Nor should our money help build a swimming pool for the guests in the proposed hotel...

As Mayor, I would pursue such an alternative with all the persuasive and executive powers of that office, keeping in mind that public projects must involve early and real participation of affected businesses and citizens. And they must be completed in all due speed within the means provided by a tired and burdened taxpayer. 22

Upon assuming office in January, 1978, Mayor Royer established the Westlake Evaluation Committee to review the project. The Committee was made up of a broad range of citizens, 
including architects, Council members, community activists, neighborhood and downtown business people, developers, the City Attorney and the Director of the Department of Community. Victor Steinbrueck was on the committee. ${ }^{23}$ At the same time as that committee deliberated, the Royer administration continued discussion with Mondev. Following an earlier initiative by Schell, the Seattle Art Museum was induced to join the project.24 On April 21, 1978, Mayor Royer announced a revised concept of the Westlake Project which replaced the 300 room hotel with the main facility of the Seattle Art Museum, an existing non-profit institution (see Figure 30). The new proposal decreased the scale of the project, added public roof gardens, closed Pine and extended north of Stewart. Project planning moved ahead. In the summer of 1978, Mitchell/Giurgola initiated design work on the revised project. Schematics and preliminary specifications were completed in September, 1978.25

An appeal of the EIS filed by Steinbrueck and the Committee for Alternatives at Westlake (C.A.W.) was denied by the Hearing Examiner in January, 1979. Victor Steinbrueck objected that Royer's process was rushed. He argued that one Council hearing was not acceptable public participation since it had allowed only five minutes for organizations and three minutes to individuals, and only three City Council members had been present. Critics compared the proposal to San Francisco redevelopment projects and Yerba Buena style displacement.26 However, the Council approved the project on October 19, 1978. Development agreements were executed between 


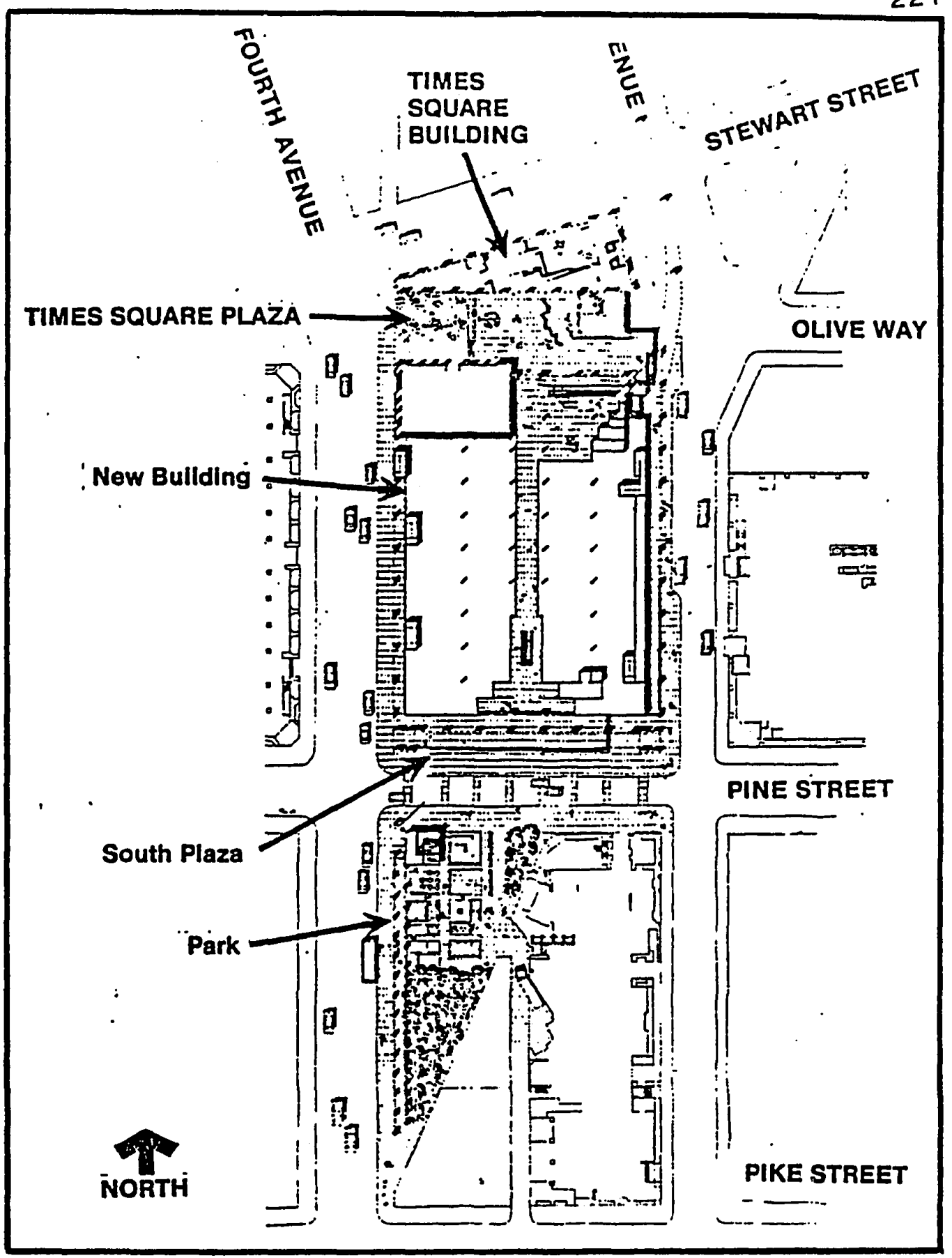

Figure 30. Mayor Royer's Westlake Proposal, 1978. From City of Seattle, Supplemental Draft Environmental Statement for the Westlake Project (1978). 
the City and the Westlake Development Authority (WDA); and then among the WDA, the Seattle Art Museum and MONDEV, USA.

Subsequently, Westlake Associates (a limited partnership consisting of MONDEV, USA and the Seattle Art Museum as limited partners) and . Daon Corporation as the general partner replaced MONDEV as the development entity. The City issued $\$ 12.6$ million in General Obligation Bonds, and an immediate appropriation of $\$ 942,000$ for project implementation activities. The Department of Community Development negotiated the purchase of four of the nine properties necessary for the planned project. HUD granted $\$ 2.8$ million toward purchase of the properties.

\section{Demise of Mondev/Seattle Art Museum Proposal}

Westlake Project property owners filed suit to stop the project. ${ }^{27}$. Why, they asked, wasn't land being condemned for a public purpose like the park rather than a competing commercial use? Charles Royer testified that "the city changed its original plan after finding that large urban open spaces often became places where criminals, drunks and derelicts congregate."28 The property owners facing condemnation argued that:

1) The Westlake Project is not a "public use" under the Washington State Constitutional provision controlling the taking of private property through condemnation proceedings (Art. 1, Sec. 16, Amendment 9).

2) The establishing of the Westlake Project is not a valid municipal purpose. 
3) The relationships established among the parties to implement the Westlake Project violate the state constitutional provision prohibiting a municipality from making a gift or lending its credit to private corporation (Article 8, Sec. 7).

4) The Amended Tripartite Agreement (WDA, Seattle Art Museum,, Westlake Associates ) violates state bidding requirements.

5) Using Forward Thrust moneys to develop the triangular park component of the project is an improper diversion of such bond proceeds.

6) The City of Seattle has no statutory authority to condemn for the Westlake Project.

7) The City is not authorized to give to the WDA nor is the WDA authorized to receive from the City either money or property.

Appeals were carried to the Washington State Supreme court. The DSDA filed a brief in support of the City through the law office of Jim Ellis, of Forward Thrust fame (see Chapter II). The court ruled against the City on the issue of public use in a 6-3 decision. The City was prevented from acquiring three properties through condemnation. 29

Subsequent efforts were made to revise the project with the Seattle Art Museum (SAM) purchasing the properties. However the City and the museum could not reach mutually acceptable terms of sale. In March, 1982, SAM announced its intention of seeking another downtown location. ${ }^{30}$ As a result, Mayor Royer recommended to City Council that the City sell its property at Westlake under tight design restrictions (April 13, 1982). Steinbrueck again argued that the 
City should build a park and that a sale to a developer could not "provide an aesthetically satisfying public open space" as the "heart of downtown." Royer simply said that the City could not afford such an alternative. ${ }^{31}$ Royer also received advice from the Westlake project manager, Barry Getzel, that incorporating Steinbrueck's ideas about maintaining a sense of open space along the old Westlake alignment would discourage developer interest. Royer denigrated Steinbrueck's desire to reduce the private Wintergarden space in favor of a larger public plaza by characterizing such an increase in public space as the "Steinbrueck cut."32

On July 6, 1982 the City Council narrowly voted to sell the Westlake site.33 A Westlake Proposal Evaluation Committee made up of citizens experienced in design, finance, and development was subsequently established by the Mayor and the City Council to select a purchaser. This was a small committee of downtown influentials: developer Donald J. Covey, architect David Hewitt, builder David Wright, financier Robert B. Filley, and attorney Calhoun Dickinson. William Whyte was selected as the outside expert.

The prospectus offered to sell two-thirds of the block located between Pine and Olive Streets and Fourth and Fifth Avenues, 25,500 square feet of the Westlake Avenue right-of-way, and a portion of the adjoining alley for $\$ 7.8$ million in cash, approximately $\$ 1$ million in utility work and $\$ 1.8$ in monorail terminal redevelopment work for a total of $\$ 10.6$ million The purchaser was expected to meet the following project goals: 
1. To provide an aesthetically satisfying public open space. This space should become a center for general pedestrian-oriented amenities, both in the day time and at night; a place where people can pause and relax and enjoy the natural mix of people away from the rush of the City. It should also potentially provide a gathering spot for public events and celebrations. Therefore, the project should become a point of public pride to local residents.

2. To strengthen the retail core. The project should encourage additional investment in the retail core and strengthen the identity of the area. It should further encourage an appropriate mix of quality businesses, have a pedestrian orientation, minimize vehicular/pedestrian conflict, encourage day and night downtown utilization and improve the urban design quality and general quality and amenity of the area.

3. To redevelop the downtown monorail terminal in a manner compatible with the above goals. The new terminal should be a functional, aesthetically pleasing facility that: provides easy handicapped access, provides for efficient circulation of monorail patrons, interrelates well with downtown public transit, meets the highest standards of safety and comfort and provides the most efficient utilization of underlying and adjoining land area.

Despite this ordering, the retail anchor was the City's first priority. The developer was also constrained by the following siting requirements and design standards: permitted uses included small shops and restaurants, a retail department store and public space. A minimum of 15,000 square feet of ground level space was required. The maximum height was regulated only in the vicinity of Pine Street. Towers greater than 150 feet were to set back at least 100 ft. north of Pine Street. The monorail was to be incorporated into 
the project. The maximum FAR was 5.3:1, although the FAR could be increased to 6.5:1 FAR if additional public space were to be provided. The design of the building was to be complementary to other department stores nearby and the project plaza was to mirror the park to the south of Pine. Finally, design should recognize the existing orientation of Westlake Avenue.34 Like Portland, a two stage process was implemented in which developers submitted qualification proposals, then finalists were invited to submit proposals. 35

\section{ROUSE ENTERS THE SCENE}

The selection of Rouse has been described as victory through attrition. The other serious contender, Emerald Place Associates insisted on a program incompatible with the prospectus. After exhaustive negotiations, Seattle had only Rouse. Rouse's design was too inward-oriented for the Westlake Advisory Committee. But Rouse was known as a retail-driven corporation and Filly and other business interests were especially concerned that the retail component be viable.

\section{Continued Opposition}

During the public review process there continued to be concern over the private nature of the project (see Figure 31). Margaret Pageler of Allied Arts and Fred Bassetti now opposed the project and joined Victor Steinbrueck and the group of architects who essayed in the Seattle Weekly as the Gang of Five.36 The City Council objected 


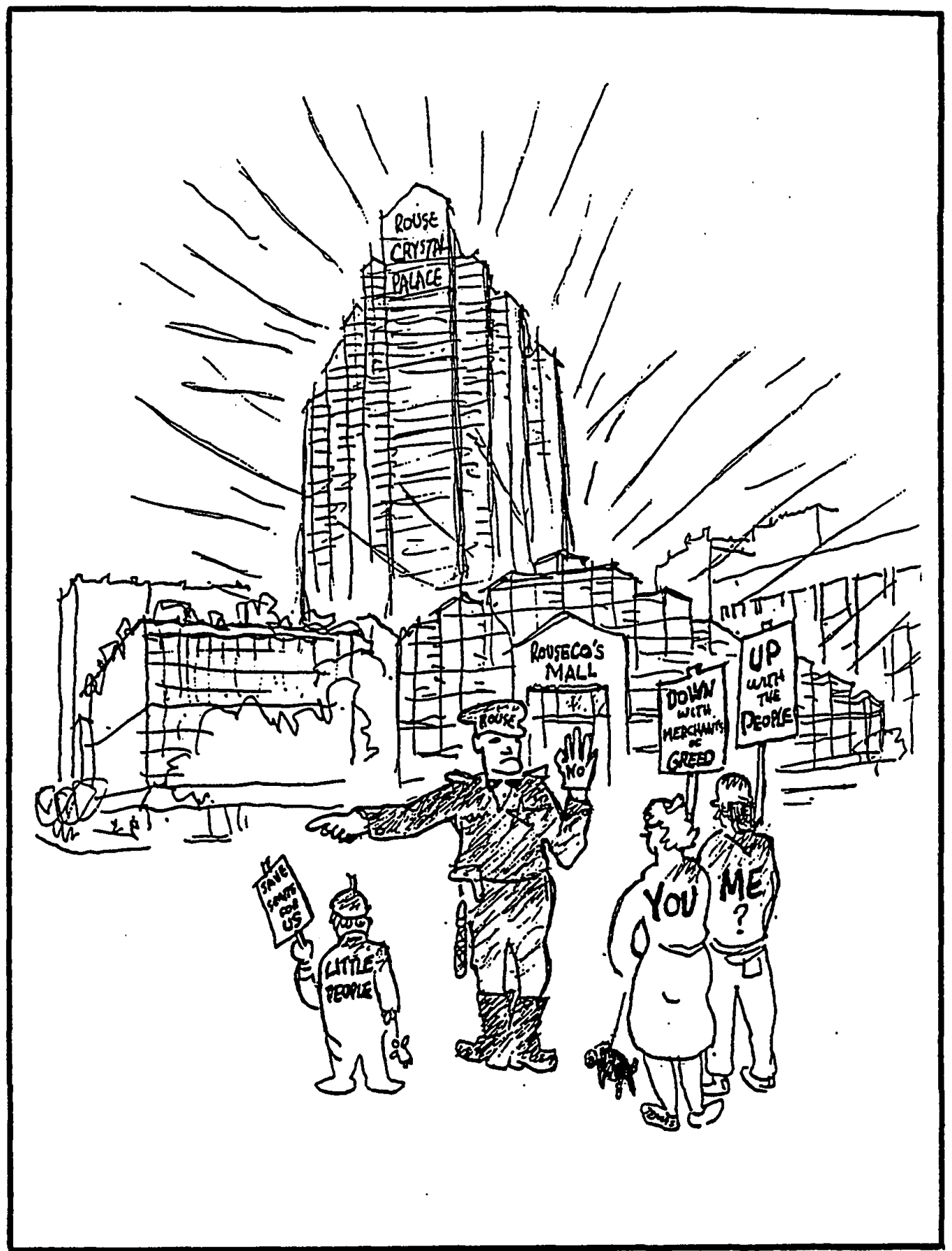

Figure 31. Private Public Space vs. Public Public Space at Westlake. From City of Seattle, Final Environmental Impact Statement Westlake Property Disposal and Development (1983). 
to Rouse's proposal to locate the monorail over the Fifth Avenue sidewalk. 37

In fact, the design would never be satisfactory to the community. The Seattle Weekly editorialized that the project had declined from an exciting "civic vision" to a "ho-hum shopping mall" (see Figure 32)."38 There would be general community dissatisfaction with the 18 story tower dropped right on the vacated Westlake right-of-way. There would be no strong lead person/agency for the City. The city review process would be split between the Department of Community Development, Department of Community Land Use (regulatory review) and Parks. The Design Commission would have no formal role. Rouse was able to design and redesign without any serious objection by the evaluation committee who feared to delay the project. Yet, the City was able to incorporate a tie with an important underground mass transit project, the bus tunnel project. ${ }^{39}$

C.A.W. appealed the final EIS statement and the Hearings Officer remanded the EIS to the City for supplemental information on shadowing, current uses, project economics, architectural massing and a space analysis. The City Council authorized execution of a Contract of Sale with Rouse on September 26, 1983. In May, 1984 further C.A.W. appeals were denied. Only Denny Regrade neighborhood, immediately adjacent to the north and the most impacted area, opposed the project with C.A.W. Other Seattle neighborhoods did not see this issue as affecting their interests. 


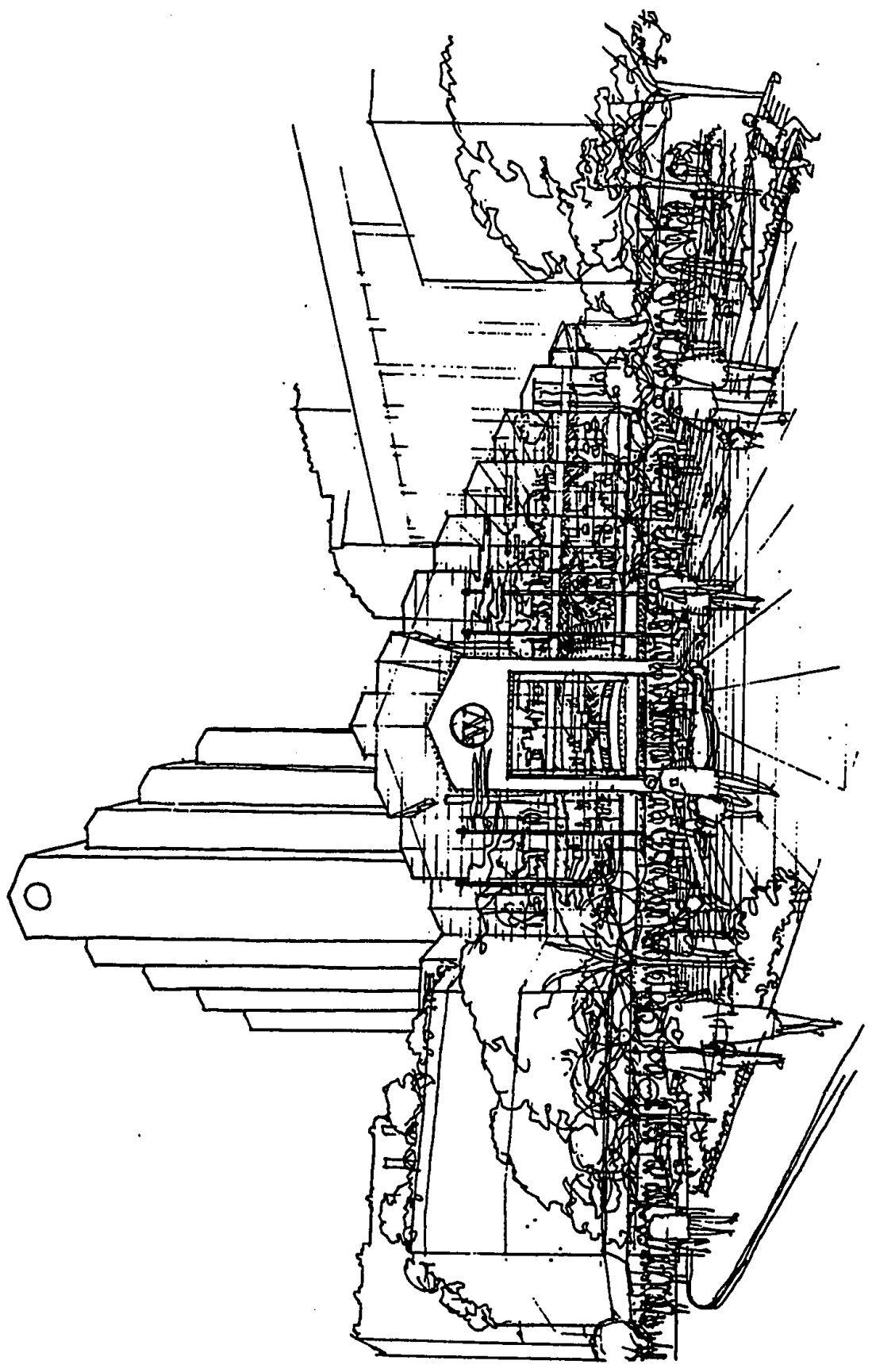

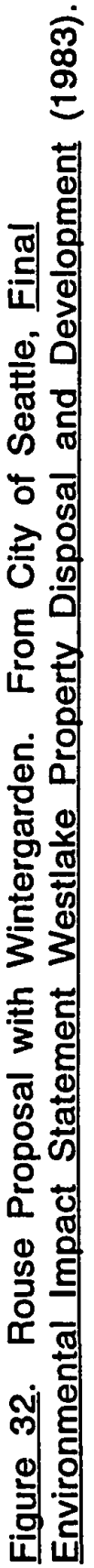


Allied Arts did not join Steinbrueck in opposition. On June 18, 1984, the City Council voted to endorse the $\$ 100$ million Rouse plan.

An internal confidential memorandum from Royer's office provides us with a snapshot of Council politics. Paul Kraabel, the Chairman of the Westlake committee, was described as "nervous," wanting Westlake to go, but also wanting low density and plenty of public space. The "recommended strategy" was to tell him that the open space would be of high quality, reinforce his understanding of the City's financial bind and convince him that there were no alternatives.

Jeannette Williams, a member of the Westlake Committee and also Council President, had concerns about transportation but was also politically pragmatic. She drew her political support from downtown and the DSA could be used to retain her vote.

Norm Rice, the third member of the Westlake Committee and also Finance Chairman, was described as fully understanding the "basics of development" and not likely to "get tied up with the aesthetics or the density issues."

Sam Smith drew support from downtown interests and minorities and his support would be reinforced by continued DSA lobbying and revenue considerations.

George Benson, who also drew support from the business community, was somewhat "fed up" with Westlake and sometimes an unreliable supporter. The recommended strategy would be to "reinforce the 'this is it or no Westlake' approach." 
Jack Richards, a first term Councilman, tended to vote with business interests. The anonymous staffer recommended "heavy use of DSA and Chamber."

Delores Sibonga, derived much support from low and middle income neighborhoods. She had voted consistently against Westlake, but as she had a good relationship with the Seattle Center, the staffer thought that the director might be able to change her mind.

Michael Hildt, the prime supporter of a Metro terminal at Westlake, was dismissed as a "burnt-out" lame duck. There seemed to be no need to "waste much time" trying for a yes vote.

Virginia Galle was disliked by the downtown community and derived much of her support from neighborhood activists. "She is strongly against most new development and is literally in the 'no growth' camp."

Clearly, the connection was made between downtown political ties and support for the project. 40

A Contract of Sale between the City and Westlake Associates (Rouse-Seattle, Inc./Koehler, McFadyen \& Company) was finally executed on August 17,1984 . The sale price was $\$ 7.6$ million cash; $\$ 1$ million for city utility work and $\$ 1.8$ million for the monorail. (The park south of Pine was budgeted at $\$ 7.8$ million.) $)^{41}$

C.A.W.'s persistence in court resulted in a redesign which Steinbrueck and Folke Nyberg could accept. 42 The compromise was announced at the October 10, 1984 news conference. The Rouse Company redesigned the project to move the southern mall perimeter to the north away from Pine Street, thereby increasing uncovered 
public space from 2,000 to 15,000 square feet. The increased setback from Pine Street caused the project to drop its "Wintergarden" and push the shops back into a conventional mall arrangement. The six-sided 23 story office building was changed from multi-faceted and glassy to beige and boring to "complement" the surrounding terra cotta department stores. The City paid $\$ 156,800$ in business relocation expenses and $\$ 33,000$ in legal expenses. 43

As construction commenced, the community reaction, especially that represented by the readership of the Seattle Weekly, was that of disappointment. The Weekly had actively disliked the Rouse proposal. The Weekly noted that at every stage, Rouse's design was found wanting. The City asked Rouse for revised concepts, schematics, and design development plans. The record bears that observation out. For example, David Moseley, of the Community Development agency wrote to Rouse on April 9, 1986 to withhold formal approval of the schematic drawings. The City referenced specific concerns of the Westlake Evaluation Committee, Citizens for Alternatives at Westlake, the Seattle Department of Construction and Land Use, the Seattle Engineering Department and the advisory Interdepartmental Design Review Group which consisted of DCLU, Engineering and Parks. 44 Media and community mistrust was high. "Blunders" such as mismeasuring the monorail and the resultant relocation outside the project were seen as cold calculated moves by the developer. 45 This was a $\$ 16$ million dollar mistake. Norm Rice, who would win the mayoral contest four years 
later, made the monorail an issue in his unsuccessful bid to be mayor in 1985.46

\section{The "Battle of Westlake"}

Once the buildings were down, Seattle activists began to imagine a true civic space instead of the miniature triangle south of Pine (Figure 33 shows what might have been.). The Seattle Times changed its position and editorialized in support of the larger square. Columnist Emmet Wilson publicized the challenge. The League of Women Voters, Allied Arts and others organized the People for an Open Westlake. Over 13,000 Seattle-ites signed petitions for a public square at Westlake in the spring of 1987.47

In June of 1987, People for an Open Westlake almost succeeded. By paying the developer for costs of the tower to date, the tower could be eliminated from the project. POW also proposed converting all of the planned underground parking to short-term, retail use, eliminating the Monorail terminal, and redesigning the axis of the shopping arcade into a more public galleria, with a better looking entrance on the north. The City would need to raise approximately $\$ 15$ million. Commissioner Jim Street led the charge. David Brewster, editor of the Seattle Weekly, described the "Battle of Westlake" as a desperate attempt to get six signatures before Mayor Royer learned of the "machinations." In the end, Commissioner Street could only get the signatures of five commissioners. Mayor Royer was tipped off and released the draft proposal "and all parties ran for their foxholes."48 Meanwhile, the park's cost (the triangle south of Pine) spiraled to $\$ 18$ million, 


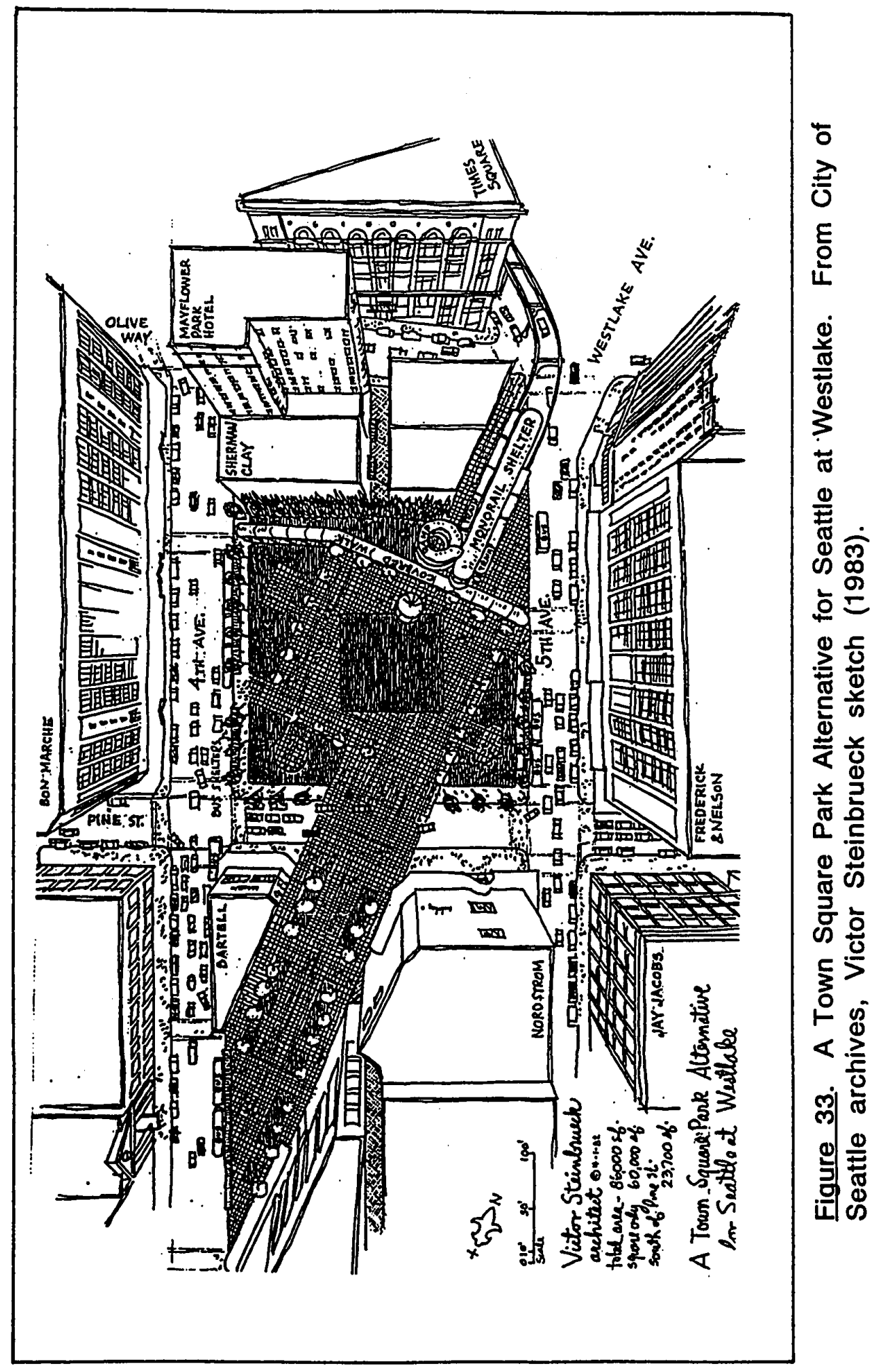


more than the People for an Open Westlake proposal to the City would have cost. 49

The grand opening, delayed once, took place on October 20, 1988. The debate still raged whether Pike Street should be closed. Heavy traffic was destroying the granite pavers. Royer granted the community a last-minute favor by deciding to keep Pine Street closed. And when a tie developed at Council, the new mayor, Norm Rice, declined to cast the deciding vote in the direction of the downtown business community. The "Battle of Westlake" had disturbed the politics of downtown, a little too late. 50

\section{CONCLUSION}

This chapter has described the conflict between the downtown/city hall urban regime and a succession of civic organizations and individuals. The 1965 Comprehensive Plan called for open space along Westlake Boulevard. Forward Thrust earmarked $\$ 1,750,000$ for downtown parks. Yet, with the need identified by the plan and with the money in hand, Seattle got a suburban shopping mall and small but expensive triangular park separated from the mall by a disused city street. The urban regime had built on the basis of potential financial return.

Figure 34 illustrates the workings of the urban regime. As the project history spans several decades, the answers to our three theoretical questions illustrate a profound shift from easy community acceptance of the regime's retail project to the public perception of a sell-out by the City, from the lone opposition of 


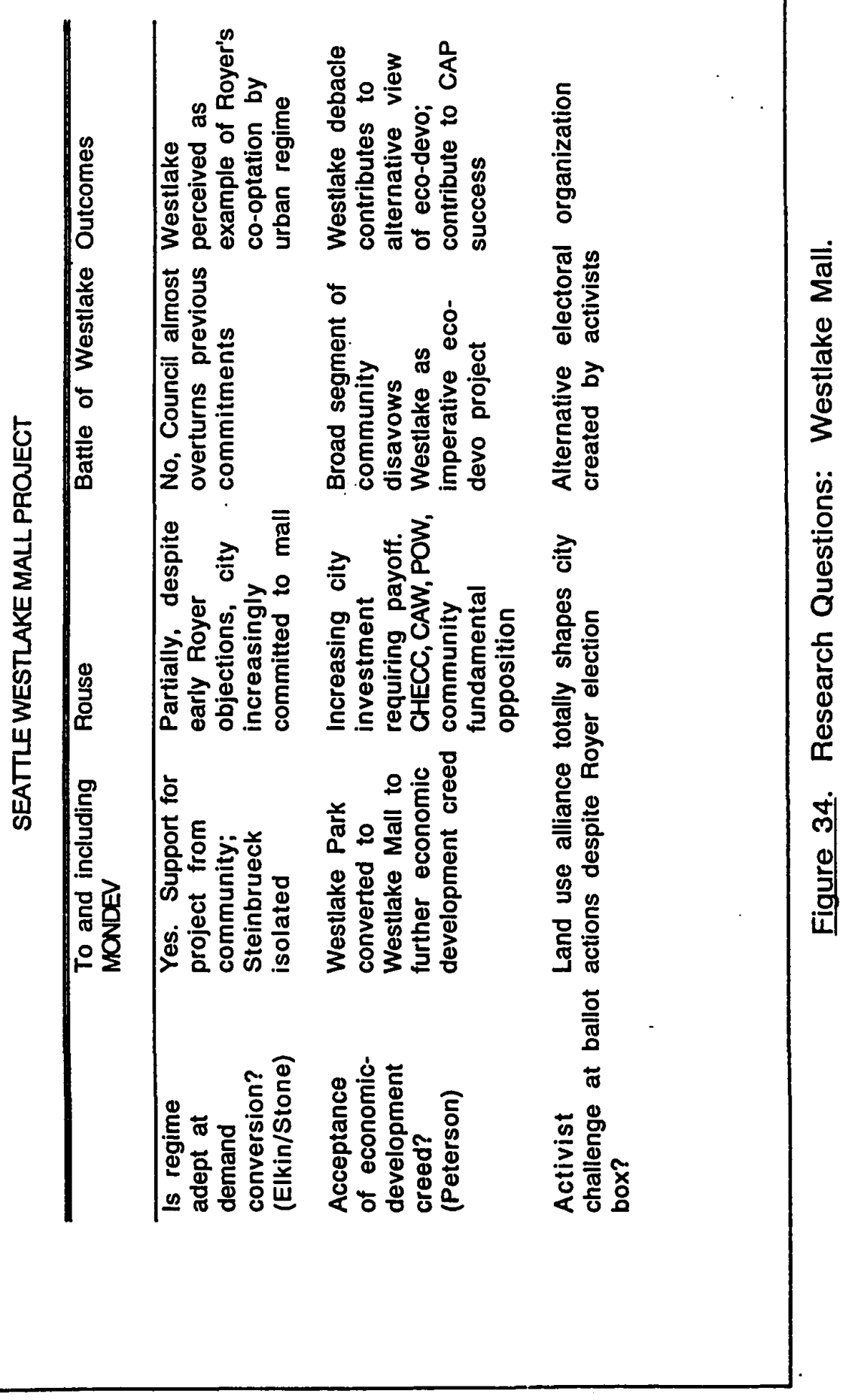


Victor Steinbrueck to mass community disaffection. Ultimately, the Westlake debacle contributed to CAP's and Vision Seattle's success.

From the beginning, project supporters were unable to distinguish private from public interest. Despite Seattle's unique. good fortune to have Pike Street Market at one end and a healthy retail core at the other end of Pike, standard retail revitalization strategy called for a private, inward-oriented shopping mall to "anchor" a downtown's retail core.

The Westlake Committee named by Uhlman reduced the park to the existing right-of-way of Westlake Boulevard. The urban regime was unwilling to create additional public space. The Chamber of Commerce, Downtown Seattle Development Association, Allied Arts and the League of Women Voters and the newspapers represented mainstream downtown interest who saw the redevelopment potential and desired to condemn private property for predominantly private development. These interests ignored demands by Victor Steinbrueck for a better balance between public and private interests and launched the project. Westlake Park became subservient to Westlake Mall in the interests of economic development.

Royer promised a rebalancing of public and private interest but confused the public spiritedness of the Seattle Art Museum with public interest. The City was forced to abandon the project by the courts but refused another opportunity to build a park as suggested by Steinbrueck. 51 By this time, the City was acting on the basis of its sunken costs, attempting to get something built. Public concerns 
over the inward nature of the project and the introduction of an office tower into the scheme were ignored by Council. The confidential staff memo clearly ties Council approval to the business community's desires. The land use alliance directed the City's intent away from the voters' wish for open space.

Community conflict accelerated as the project commenced. Steinbrueck compromised with the City, gaining as much open space as possible. It was the pending lawsuit, not reasoned opposition which pressured the City to compromise. Once the buildings were down, Seattle activists could point to the dimensions of the park if the shopping center were not built. The project's support was narrowed to City Hall and downtown business interests, but strengthened by the momentum associated with construction. Allied Arts, the League of Women Voters and the newspapers abandoned the project and pursued a park for the third time. These activists were defeated by Royer. However, they became part of the generalized opposition to the downtown land use alliance. Citizens Against Westlake, and People for an Open Westlake eventually merged with the Sierra Club, the Seattle Displacement Coalition and Vision Seattle to create an electoral alternative to the urban regime.

A comparison between the two cities shows that in Portland the urban regime successfully negotiated a process by which influentials were satisfied that the commercial public interest was being served. In Seattle, the urban regime never balanced public and private interests to its critics' satisfaction. 


\section{ENDNOTES}

1Fred Bassetti, "Seattle's Heart: An attempt at definition," undated, Royer's papers, Seattle Municipal Archives. Background intervlews were conducted for this chapter with Denny Brewster, July, 1991; Bill Duchek, July, 1990; Waiter Hatch, September, 1990; David Hewitt, March, 1991;Paul Kraabel, July, 1991; Skip Norton, March, 1991; James Pearce, July, 1990; Peter Steeinbrueck, September, 1990 and Pat Strosahl, March, 1991.

${ }^{2}$ Charles Royer, Charles Royer for Mayor: On the Issues. Westlake Mall, March 17, 1977. Royer papers, Seattle Municipal Archives.

City of Seattle, Department of Community Development, Westlake Project Draft Environmental Impact Statement, December, 1979.

3The proposal was titled "Action: Better City."

4Friends of the Pike Place Market and others defeated the city's and business community's proposal to raze Pike Street Market in November, 1971. Voters preserved an old-fashioned produce market very different from the ultimate Rouse project at Westlake. Bernard J. Freiden and Lynn B. Segalyn put Pike Street Market into the context of core retail development history in their book, Downtown. Inc. How America Rebuilds Citles, Chapter 6.

Arqus, "Westlake Mall plan nixed by businessmen; Forward Thrust project cut to ribbons by Bon Marche," August 13, 1971.

5 Skip Norton, interview, March, 1991. Archives.

6Barbara Dingfield to Wood, April 30, 1973, Royer's Papers, Seattle Municipal

Westlake Project Draft Environmental Impact Statement, December, 1979.

${ }^{7}$ City of Seattle, Westlake Advisory Committee, Report of Mayor's Westlake Committee, April 12, 1973. 1974.

${ }^{8}$ Coldwell Banker, "Retail and Economic Feasibility of the Westlake Park," August, 1973.

${ }^{9}$ Seattle Times, "\$60,000 study OK'd for Westlake Mall project," September 6,

Seattle Times, "Uhiman signs for Westlake study," November 3, 1979.

${ }^{10}$ City of Seattle, Department of Community Development, Westlake Final Environmental Impact Statement, May, 1975.

11 Displaced tenants included shoe stores, a drug store, book stores, jewelers, sporting goods stores, restaurants, a photo service, a plant, gift and cards shop, a candy store, a pharmacy, a barber shop, offices, banks, opticians, a ticket office, a bridal shop, travel agent, etc.

${ }^{12}$ City of Seattle, Westlake Prospectus, 1982. 
${ }^{13}$ Seattle Times, "Developers get look at Westlake plans," September 14, 1975.

Seattle Times, "Montreal firm chosen for Westlake project," November 4, 1975.

Seattle Times, "Westlake developer long on sensitivity," November. 9, 1975.

Seattle Times, "Westlake Park sult threatened," November 27, 1975.

Seattle Times, "Goal is new life for downtown," July 1, 1976.

14David Brewster, "Once More, With Westlake - If this brilliant architectural solution to Westlake Mall won't work, it's time to give up," Seattle Weekly July 7-13, 1976.

${ }^{15}$ Seattle Times, "Five groups agree to back Westlake Mall plan," March 3, 1977.

${ }^{16}$ Seattle Times, "Suit against city threatened," February 23, 1977.

Duff Wilson, "Making of a downtown mall," Arqus March 18, 1977.

${ }^{17}$ Seattle Times, "Westlake Mall tenants unite against city plan," April 25, 1975.

David Altaras, "Westlake Mall plan seen as big-business ploy," Seattle Times April 30, 1975. Seattle Post-Intelligencer, "Initiative threat in Westlake Mall," April 30, 1975.

${ }^{18}$ CHECC on Seattle City Government Park Committee, "The Park that Got Swallowed Up. Westlake Park, An easy catch for Big Fish progress?" paid advertisement in Seattle Sun, February 16, 1977.

19 Victor Steinbrueck, "Seattle Architect Evaluates Concept for Westlake Mall," reprinted from Northwest Arts August 6, 1976.

${ }^{20}$ Citizens and Merchants Against the Westlake Project. Eacts on the Westlake Park(?) Project or Ten Reasons Why We Stopped Learning To Love This Bomb, June, 1977 Seattle Municipal Library uncat. N.W. Box 33.

Seattle Times, "Virtually assured: Council unit OK's Westlake Mall," April 16, 1977: A1. "Westlake development approved.: April 26, 1977.

Seattle Post-Intelligencer "Westlake Mall project wins the go-ahead," April 16, 1977. Seattle Post-Intelligencer editorial, "Westlake Mall will help revitalize downtown," April 19, 1977.

Seattle Times, "Council approves Westlake Mall bonds (they are not subject to voter approval)," May 10, 1977.

Seattle Times, "Uhlman signs Westlake charter," December 22, 1977.

21 Duff Wilson, "Making of a downtown mall," Arqus, March 18, 1977.

${ }^{22}$ Charles Royer, Charles Rover for Mavor: On the Issues. Westlake Mall, March 17, 1977. Royer papers, Seattle Municipal Archives. 
Seattle Times, "Westlake Mall called 'end run," April 19, 1977.

${ }^{23}$ Seattle Times, "Citizens to study Westlake Mall plan," February 18, 1978.

${ }^{24}$ Seattle Times, "Royer defends closed-door Westlake talks," March 12, 1978.

Seattle Times, "More closed meetings expected on project." March 18, 1978.

${ }^{25}$ Seattle Times, "Art museum may be focus of new Westlake Mall plan," April 19, 1978.

Seattle Times, "Westlake Mall Will Be Smaller Says Royer," April 20, 1978.

Seattle Times. "Royer asks Council to OK revamped Westlake plan," April 21, 1978.

${ }^{26}$ Seattle Times, "Supporters, foes debate Westlake Mall project," March 23, 1978. Seattle Sun, "Royer mall plan not out of woods yet," May 17, 1978.

Seattle Times, "Steinbrueck blasts Westlake redesign," October 6, 1978. Seattle Post Intelligencer, "Dean of architecture praises mall design," October 8, 1978. Seattle Times, "City Council hearing: Mall project roundly criticized, October 20, 1978.

27 The citation is In RE Seattle 96 Wn 2 d616.

${ }^{28}$ The citation is (EX 17 \& $1(B)(17)(b) ; C P ~ 104-105$ Affidavit, para 6).

${ }^{29}$ Seattle Times, "Lawsuit seeks to scrap mall plan," November 22, 1979. 4, 1980.

Seattle Times, "Westlake Mall project faces opponents in courtroom today," December

Seattle Times, "Westlake Mall foes to challenge city in court," December 6, 1980.

Seattle Times, "Court ruling derails Westlake Mall plan," December 16, 1980.

Seattle Times, "Officlals not giving up on Westlake Mall," December 17, 1980.

Seattle Times, "High court to get Westlake appeal," December 24, 1980.

Herb Robinson, "Westlake case: Defining a 'public purpose'."- Seattle Times January 7. 1981. 10. 1981 .

Seattle Times, "Westlake Mall proposal loses second round in legal fight," February

Seattle Times, "City to appeal Westlake Mall ban," February 24, 1981.

Seattle Times, "Future of Westlake project up to High Court," March 15, 1981.

Seattle Times, "Both sides argue appeal on Westlake Mall," June 16, 1981. 
Seattle Times, "It's the last of the ninth for Westlake Mall; court hears plea," June 15, 1981. Seattle Post-Intelligencer, "State court hears both sides on Westlake Mall debate," June 16, 1981.

Seattle Times, "Despite adverse ruling, Royer sees new mall," December 25, 1981.

Seattle Times, "Court ruling latest woe for Westlake developers," January 26, 1982.

Susan Gilmore, "Royer struggles to revive Westlake Mall project," Seattle Times

March 9, 1982.

${ }^{30}$ Cynthia H. Wilson, "Westlake R.I.P. SAM and the city shelve their scheme for a downtown square," Seattle Weekly, March 31, 1982.

${ }^{31}$ In his letter to C.A.W. Royer stated that the city's strategy was the result of "a realistic appraisal of how to achieve our long-term objectives." Royer to C.A.W., September 21, 1982, Seattle Municipal Archives.

32Victor Steinbrueck, letter to Charles Royer, Royer papers, Seattle Municipal Archives. David Hewitt, interview, March, 1991.

${ }^{33}$ Seattle Post-Intelligencer, "Council passes new Westlake plan barely," July 7 , 1982.

${ }^{34}$ City of Seattle, Department of Community Development, Westlake Prospectus, 1982.

${ }^{35}$ To qualify, each prospective purchaser would submit materials relating to purchaser's development experience - 30 points; financial capability - 30 points; project architecture/planning/design experience - 30 points and evidence of Local (Seattle Area) Participation - 10 points. To win, each qualified developer would be judged on the nature and quality of the proposed development - 40 points; the ability to financed the proposed development - 40 points; tenant resettlement opportunity - 10 points; and relative experience - 10 points.

36Polly Lane, "Westlake development breeds talk without action," Seattle Times February 13, 1983.

37 David Hewitt, Interview, March, 1991.

${ }^{38}$ David Brewster, "The latest Westlake Mall plan: Trading away design integrity," Seattle Weakly October 31, 1984, :2, 54.

${ }^{39}$ Seattle Weekly. "Westlake Solution \#74: A transit hub for Seattle. The Gang of Five makes a peace proposal in the Westlake Downtown Transit wars," November 10, 1982.

Cynthia H. Wilson, "Good design, bad politics Could City and Metro pull off a joint project at Westlake?" Seattle Weekly December 15, 1982.

Seattle Times, "Royer blasts Metro's plan for transit center near Westlake Mall," January 21, 1983. 
Seattle Times, "Metro committee won't consider Westlake Mall for transit center," February 6, 1983.

Seattle Post-Intelligencer, "A bus terminal in Westlake Mall area? That's part of Metro plan," February 9, 1983.

Seattle Times, "High-rise plan, without transit, may stir Westlake debate," June 3, 1983. Seattle Times, "Westlake proposal lacks transit link, says developer," June 12, 1983.

Rebecca Boren, "Another best solution. The mayor now knows what he wants - but Metro, the City Council, and the activists aren't so sure they like it," Seattle Weekly June 8 , 1983.

${ }^{40}$ Anonymous, "The City Council and the Westlake Project," Royer's papers, Seattle Municipal Archives.

${ }^{41}$ Seattle Times, "Westlake plan wins nod of City Council majority," September 24, 1983. 1984.

Seattle Post-Intelligencer, "Royer signs contract for Westlake Mall." August 18,

42The citation is (CAW v. Seattle et. al. King Co. NO. 82-2-155110).

${ }^{43}$ Seattle Post-Intelligencer, "Westlake Mall plan under fire - againl" June 7, 1984. 10, 1984.

Seattle Times, "Both sides gain in settlement of lawsuit over Westlake plan," October

Seattle Post-Intelligencer, "Doug Jewett gets credit for ending Westlake stalemate," October 11, 1984.

Seattle Times, "Westlake Mall feud settled in nick of time," October 14, 1984.

Memorandum of Settlement. Royer papers, Seattle Municipal archives.

44David Brewster, "The latest Westlake Mall plan: trading away design integrity," Seattle Weekly October 31, 1984.

"Memorandum, "Moseley to Rouse, April 9, 1986.

45 Seattle Times, "Monorail snags Westlake Mall plans," May 20, 1985. 21, 1985.

Seattle Times editorial, "Monorail Blunder: Why didn't they measure it sooner?" May

Rebecca Boren, "Westlake: Whaddaya mean you didn't measure it," Seattle Weekly, May 29, 1985.

Seattle Times, "Plan puts monorail back on track," June 29, 1985.

46 Seattle Times, "Rice makes Monorail an issue in race for mayor," July 9, 1985. 
${ }^{47}$ Seattle Times, "A Times 'Phototorial': What's wrong, and right, with this picture?" February 17, 1987.

Emmet Watson, "Big hole leads to big dreams at Fifth and Pine," Seattle Times, February 24, 1987. 1987.

Seattle Times editorial, "Too late? City is 'trapped' in Westlake plan," March 1,

Seattle Times, "Unbiased" look at Westlake is urged," March 3, 1987.

John Hamer, "One Final Shot: 'POWs' make a last stand at Westlake," Seattle Times, March 5, 1987.

Seattle Times editorial, "Is this really the best Westlake plan? Issue deserves one last debate," March 8, 1987.

Seattle Post-Intelligencer. "Foes of Westlake Mall claim growing support," March 19, 1987.

Seattle Times, "Westlake supporters petition city," March 31, 1987.

Seattle Post-Intelligencer, "13,000 sign petitions for a public square at Westlake," March 31, 1987. 12, 1987.

Emmet Watson, "High-rises: their time has come--and gone," Seattle Times April

${ }^{48}$ Seattle Times. "Westlake: is a change in plans still possible? City official to approach developer," April 12, 1987.

Seattle Times, "Buyout attempt already was dead: Five on council opposed tower," April 28, 1987.

Seattle Times editorial, "Gallant Effort: Last chance for a Westlake compromise," April 29, 1987.

Seattle Times, "A vision of space: Seattle architects could picture Westlake plan so clearly, they felt certain others could see it too," May 6, 1987.

Curtis R. Bales, "The Ugly Rouse Project: Land-use travesty at Westlake site." Seattle Times, June 19, 1987. 1987.

David Brewster, "Who really won the battle of Westlake," Seattle Weekly, June 24,

${ }^{49}$ Seattle Times, "Council gives final OK to Westlake Park. Down to $\$ 18$ million, it's still city's costliest," February 3, 1988.

${ }^{50}$ Seattle City Council member Jim Street, interview, March, 1991. 
Seattle Times, "Mayor won't lead crusade to keep cars off Pine Street," August 23, 1988. Seattle Times editorial, "An appealing idea: Keep Pine St. closed and Westlake open," August 29, 1988.

Seattle Times, "Downtown Seattle against Pine closure," September 1, 1988.

Seattle Times. "City council split over plans to keep Pine Street closed," September 13. 1988.

Seattle Times, "Pine Street debate: Closure plan draws hearing; council members divided," September 15, 1988.

Seattle Times, "Westlake paving problems spread; bus traffic blamed," December 9 , 1988. Seattle Times, "Consultant says it may cost $\$ 500,000$ to replace granite paving at Westlake," January 13, 1989.

Seattle Times, "Pine Street repair plan may reopen closure fight. Council seems willing to approve $\$ 650,000 \mathrm{fix}^{\prime \prime}$ April 11, 1989 .

Seattle Times, "Williams buries the downtown hatchet; But Pine Street reversal may cost other votes," September 6, 1989.

51There is a triangular open space to the south of Pine. It lacks the presence of a significant civic space due to its cramped dimension and loss of sight lines up Westlake north of the mall. The original Forward Thrust concept would have allowed an open space/boulevard treatment from the retail core north to Seattle Center and Lake Union. 


\section{CHAPTER VII}

\section{FROM SKD ROAD TO NORTH DOWNTOWN}

\section{DOWNTOWN PLAN}

The 1972 Downtown Plan marked a change in public policy for the area north of Burnside. Until the concept plan map knitted the areas north and south of Burnside, downtown was considered to stop at Burnside to the north and Jefferson to the south. The 1964 Comprehensive Plan accurately characterized the area, from Burnside Street north to Glisan Street, as a wholesaling and automobile sales-service district and as the city's skid road. No redevelopment plan was proposed. The area's strategic location between the downtown core and Lloyd Center was recognized but redevelopment was not considered probable within the time span of the plan.

The Downtown Plan incorporated the area north of Burnside into downtown. Downtown now included the entire area south of Hoyt between the 1-405 freeway and the Willamette River. The concept map indicated the area to be a medium density office district, with preservation of the Skidmore/Old Town Historic District. Although the plan called for replacement housing for the single male population and allowances for special social and commercial services and facilities, the transit mall was drawn through the heart of the district. The plan envisioned redevelopment 
of the area outside of the historic district as a mix of retail, office and housing uses. Housing would be concentrated west of Third, offices to the east of Third. At the same time, the plan also called for a
high priority to increasing the number of residential accommodations in the Downtown area for a mix of age and income groups, taking into consideration differing life styles...the differing needs and problems of the various groups who will be housed, including those groups who naturally gravitate to the city core... housing and services commensurate with their physical and social needs. These groups include the single retired, the elderly, itinerant worker, "down and outers," students, and the handicapped, as well as middle and upper income groups. 1

The Union Station/Railyard area was tagged as the area appropriate for low-income housing for the "single men who live in the area" who required special social and commercial facilities (see Figures 35 and 36). However, the Downtown Plan envisioned that long-range redevelopment would displace these dependent populations. The resultant mix of retailing, offices and housing would probably leave little room for these men. The Lownsdale neighborhood at the south end of downtown would also be redeveloped but low-income housing could potentially be built in the vicinity of the Hawthorne or Morrison bridgeheads. No special social services would be provided there. The Downtown Plan identified other concentrations of existing or potential housing - South Auditorium, the Fourth-Broadway corridor south of Market Street, Skidmore Fountain, Union Station-Railyards, West of Tenth, South Park Blocks and South Waterfront - but these areas would contain 


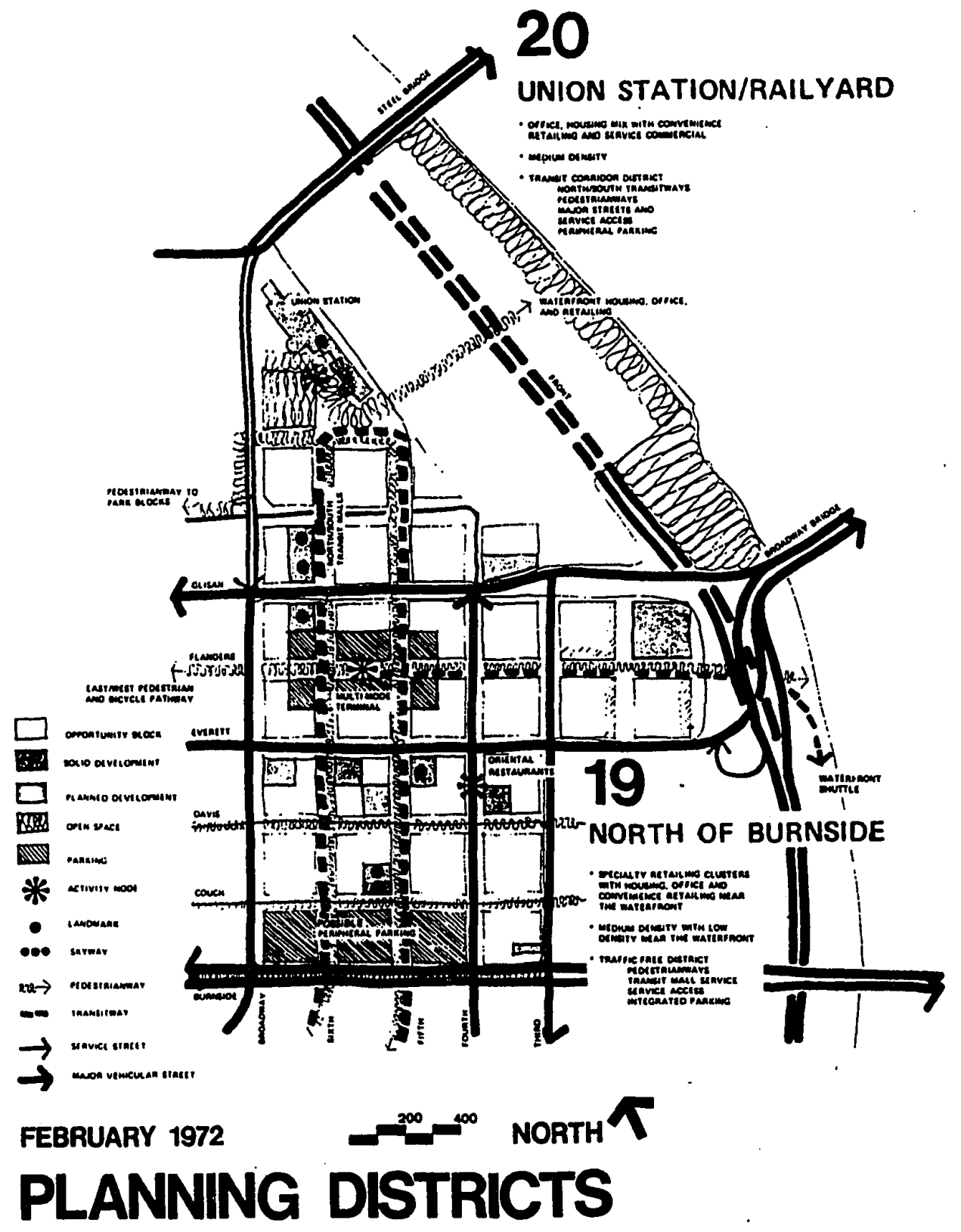

Figure 35. Union Station, Railyard Planning District. From City of Portland, Planning Guidelines: Portland Downtown Plan (1972). 


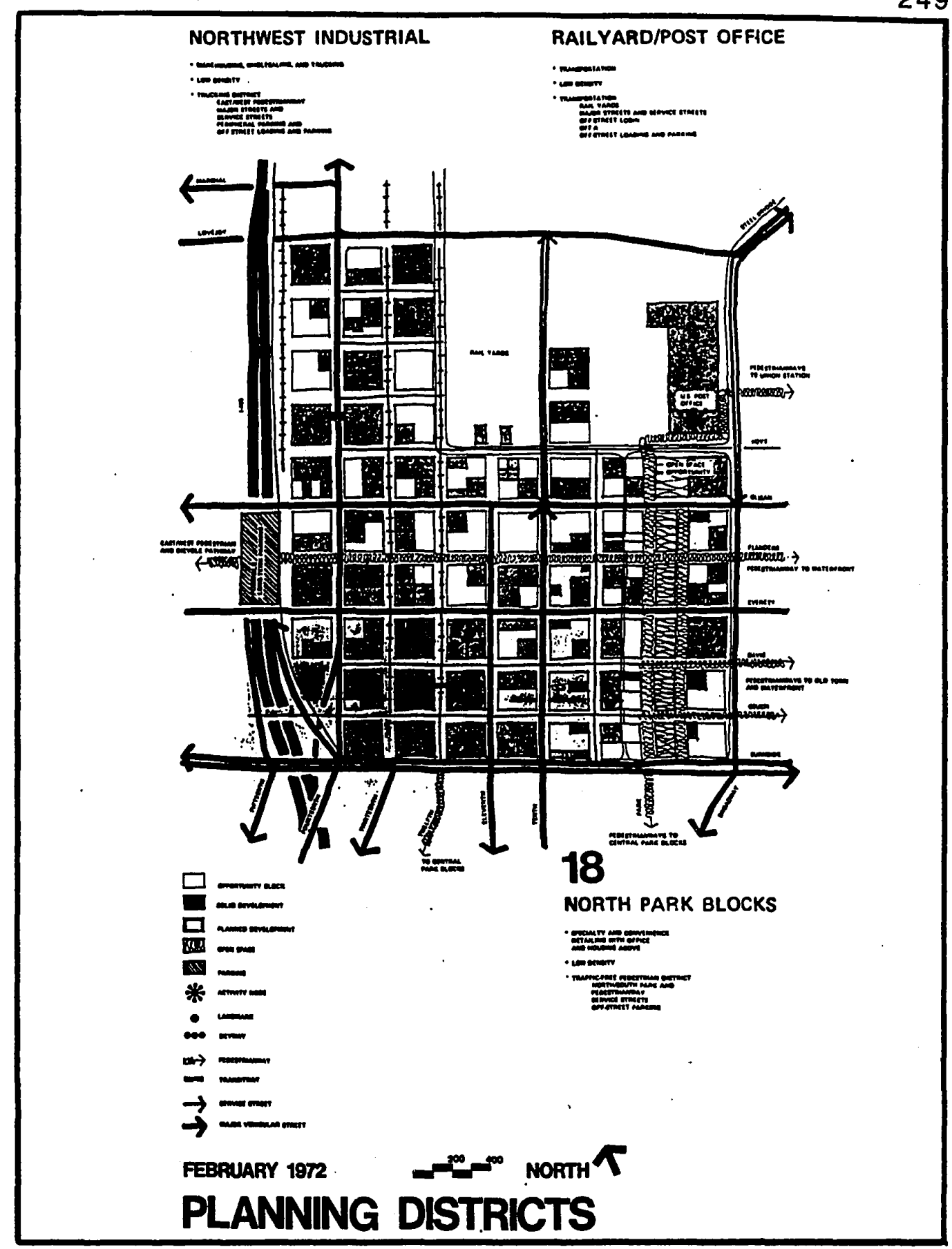

Figure 36. Northwest Industrial Planning District and Railyard/Post Office Planning District. From City of Portland, Planning Guidelines: Portland Downtown Plan (1972). 
little low-income housing and no support services. 2 In retrospect, the crucial significance of the Downtown Plan to the future conflict was its "annexation" of skid road via the proposal for office redevelopment and extension of the Transit Mall through the area. The plan's recognition of a declining supply of low-income housing and the need for the City to intervene in the market came increasingly in conflict with potential redevelopment. Citizen involvement of residents and social service providers came increasingly in conflict with the urban regime's "public-private partnership." The Burnside Community Council (BCC) was the recognized neighborhood association and had shared policy-making with U. S. Bank and the Portland Downtown Plan Office during preparation of the Downtown Plan. Yet, BCC was to be increasingly at odds with other actors in Old Town.

\section{IMPLEMENTATION OF THE DOWNTOWN PLAN}

In 1974, the City embarked upon the "second wave" or implementation phase of the Downtown Plan. The plan would be realized through new development regulations, historic preservation, and design guidelines to be coordinated by the Planning Bureau. A Downtown Parking and Circulation Policy (DPCP) would be put in place. The City would create a waterfront urban renewal district through PDC. A social plan would consider housing issues. Irving W. Shandler, Director of the Diagnostic and Rehabilitation Center in Philadelphia, was retained to visit skid road and recommend a resolution to the conflict between redevelopment and 
displacement. Shandler's report was to create "social policy" to be folded into the new urban renewal plan to be adopted to implement the Downtown Plan. This report called for the elimination of the Burnside community by requiring residents of the area to enroll in programs "that would improve their life style as an integral part of redeveloping the area in which they live" and by eliminating both small stores which catered to the local residents and agencies which provided social services. Shandler was actually advocating the destruction of the small 1,500 - 2,000 person Burnside Community. Shandler specifically stated that the Asian Community and historic resources were overvalued. ${ }^{3}$

This was unacceptable to the Burnside community. Burnside Projects (later Transition Projects), St. Vincent dePaul, and NW Pilot Projects, all private social service agencies, and Burnside Community Council, the recognized neighborhood association who provided services and advocacy for the resident population, objected. The Citizens Advisory Committee to the Downtown Plan, the Japanese American Citizens League, and the Chinese Consolidated Benevolent Association were other interested parties who disagreed with the Shandler dispersion strategy. Although the City's Bureau of Human Resources agreed that the skid road north of Burnside was undesirable, it seemed that an immediate dissolution would only create small skid roads elsewhere. The Bureau of Human Resources recommended $\$ 1,000,000$ in subsidies over the next five years to reconstruct 400 housing units. 
Despite continuing support, housing units continued to vanish. PDC was unwilling to use tax increment money for low-income housing and new building codes closed unsafe units. The Downtown Plan had called for the dispersal of the Lownsdale population but the closure of the Lownsdale, Geneva and Lenox hotels galvanized the liberal establishment into demanding action. Mayor Neil Goldschmidt appointed a Downtown Housing Advisory Committee. The group was well-balanced between businessmen and established social-service agencies. ${ }^{4}$ The Committee proposed four policy recommendations and eleven programs. The policies called for the maintenance of low-income housing, the creation of middle-income housing, the encouragement of high-income housing and City support of conversion of commercial space to housing. The policy strongly called for an absolute end to the erosion of no-and low-income housing:

The City recognizes the importance of Downtown as a low-income housing resource, appealing to a variety of needs and life-styles and supported by existing services. It also recognizes that this housing and these services cannot be effectively and economically replaced elsewhere in the City. Therefore, the City is committed to assure that the 5,183 low-income units which existed in April 1978, be maintained in the Downtown. ${ }^{5}$

The Downtown Housing Advisory Committee continued as an advisory group. However, PDC and BCD became the dominant city agencies as they had the use of HCD block grant money.

In 1978, the City organized an umbrella group, Burnside Consortium (later Central City Concern) which hoped to coordinate the 40 agencies then operating on Burnside. The first six board 
members balanced social service, property, and residential interests. The members included property owner Sam Naito, architect George "Bing" Sheldon; Peter Paulson of Burnside Projects; Bob Butler, manager of the Villa Hotel; Sherman Partridge, a resident of a SRO hotel; and Dave Hutchinson, a participant of an alcohol treatment program. Andy Raubeson, from the Bureau of Human Resources, became director. Raubeson had previously been connected with the Model Cities program. Raubeson quickly gained a reputation as capable of building and maintaining property but autocratic toward the myriad agencies on Burnside. Burnside Consortium gravitated toward bricks and mortar and left social policy to others. Burnside Community Council (BCC) was not included although it was the officially recognized neighborhood association. BCC was excluded because its director, Michael Stoops, was an outspoken critic of City Hall.

\section{North of Burnside Study}

In 1979, the North of Burnside area was set aside for special review when the 1972 Downtown Plan was revisited to measure progress in implementation. City policy restraining intense office development was seemingly challenged by the planned construction of Pacific Square, the U.S. National Bank tower and other projects. Northwest National Gas Pacific Square was a proposed five and onehalf block mixed-use project including office and commercial space, a major hotel, World Trade Center, public plaza, off-street parking garage, and athletic club. (In fact, out of a total of 2,246,305 square feet of proposed space, only a single office building was ever 
built.) U.S. National Bank proposed and later built a 37-story headquarters tower on the south side of Burnside between SW Fifth and Sixth Avenues (Transit Mall streets). These were the projects which put redevelopment pressure on Old Town. In addition, although the Transit Mall was still slated for expansion to the transportation center on Glisan, floor area allowances were lower north of Burnside than south of Burnside. Development interests argued that floor area allowances north of Burnside should be raised. Thirty projects were cited as justification for a re-examination of the lower FAR controls. (These projects were mostly rehabilitations of existing buildings.)

In order to maintain the contemporary policy of restricting development and maintaining low-income housing, the study participants had to answer six questions:

1. Is the underused land in the North of Burnside area necessary to meet the demand for downtown high density office and retail uses?

2. Is it efficient for the City to continue to target the North of Burnside area for low income housing resources and social services?

3. Are existing and planned land uses compatible with the preservation of historic resources in the North of Burnside area, particularly the Skidmore/Old Town Historic District?

4. What is the role of the North of Burnside area in the downtown transportation system?

5. Are the urban amenities represented by the North Park Blocks and Waterfront Park currently underutilized? 
6. What form of encouragement should be given the facilities and identity of the Chinese-American community in the North of Burnside area?6

Two sets of city staff were responsible for the kernel of the project, the economic study. The original economic study was directed by the Office of Planning and Development. With the abolition of OPD after Mayor Neil Goldschmidt's departure to the Carter administration, the Special Projects section of the Bureau of Planning under Commissioner Margaret Strachan evaluated the economic data and continued the process with a study committee and subcommittees on economic demand, historic preservation, housing preservation and social services. The leadership of the study committee was balanced between Jim Atwood, representing the real estate/development interests and Peter Paulson, head of Northwest Pilot Project, representing the social service agencies. Every interest was represented by the 53 members of committees and subcommittees. There were five major groups of players with specific interests: 1) big-time developers who wanted to extend the transit mall and go for "big-time redevelopment" along the lines of the gas company project (the Naitos, Kalberers and Elmakers have sizable private property interests); 2) small-time property owners and investors who had been attracted by the low rents, proximity to downtown or had always been there serving the loggers on skid road (yuppie-oriented businesses were not yet a factor); 3) historic preservationists (who had managed to get designation of the Skidmore/Old Town Historic District east of SW Fourth and who wanted to save as many buildings as possible in Chinatown) who 
were opposed to raising floor area allowances if redevelopment pressure would increase; 4) social service agencies and private operators of SRO hotels who felt the greatest threat from high floor area allowances and redevelopment pressures; and 5) the Asian community. City officials in OPD or PDC were inclined toward redevelopment of areas outside the official historic districts. The planners in the Bureau of Planning were inclined to hold the line. Richard Meier, who wrote the plan for the Bureau, became convinced during the course of meetings with Burnside Community Council and Burnside Projects that there had to be a place for the lowincome.

The study succeeded in maintaining the existing policy (see Figure 37). The area would not be slated for massive redevelopment. Floor area limitations would be kept down. At the Planning Commission review, this issue would be the only point of public dispute. Chief Planner Karen Kramer would specifically link permitted floor area to redevelopment potential. Every interest group but the big developers were in support of maintaining the status quo. The study made the following conclusions:

1. The land in the North of Burnside area is not necessary to meet the demand for downtown highdensity office and commercial development.

2. Low income housing in the North of Burnside area, particularly SRO hotels, is a significant resource and is difficult to replace.

3. Existing and planned land uses are compatible with the preservation of historical resources in the North of 


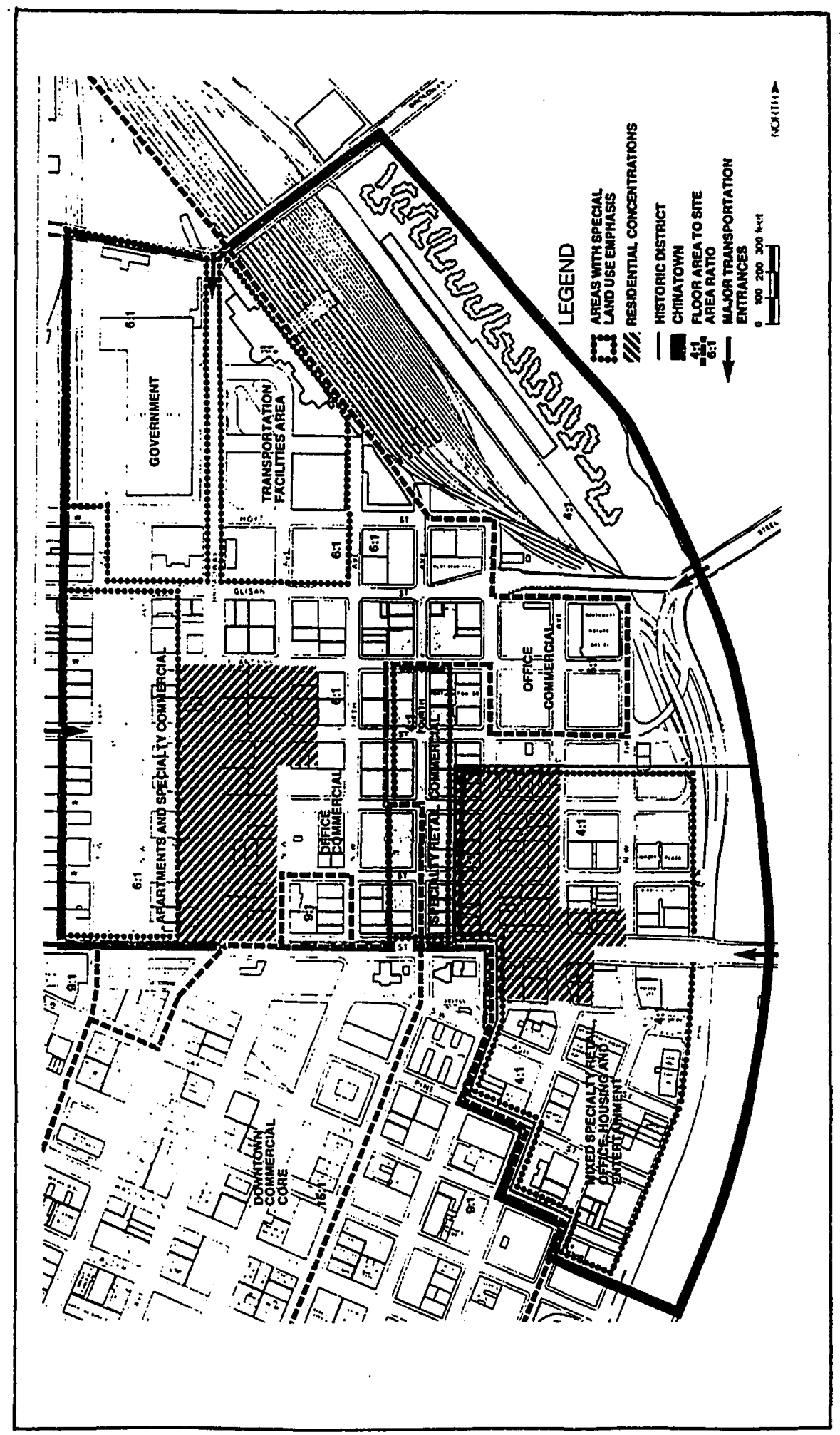

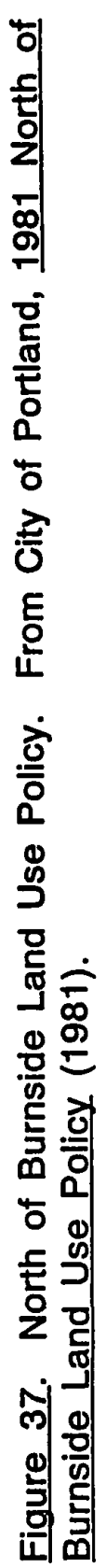


Burnside, especially Skidmore/Old Town Historic District.

4. The role of the North of Burnside area in the downtown transportation system remains one of a major entrance and terminus of downtown circulation.

5. The North Park Blocks and Waterfront Park are currently underutilized urban amenities.

6. The identity of a Chinatown area in North of Burnside should be encouraged with continued assistance to development activities and support of a request for special district designation.?

From a planning standpoint, the most important action of the Bureau of Planning had been to successfully question the economic analyses made by consultants Leland and Hobson for OPD/PDC. While the study found that up to three million square feet of commercial expansion could happen in the core, there was 4.9 million square feet of underused land just in the district and five times that in the entire downtown. 8 What had seemed to be very strong demand seriously restrained by restrictive floor areas zoning code limitations turned out, in a second look, to be sufficient regulatory permission for 37 years worth of growth in the entire downtown!

Thus the plan successfully resisted the push for dispersal as had been suggested by Shandler and partially implemented by the gas company. Other accomplishments of the plan included finding a permanent place for the district's weekly crafts market, promoting the Chinatown District and recognizing the historic value of Union Station. A compromise on social services projected their removal from the heart of Old Town and relocation northward to Flanders and Glisan. The North Park blocks would be redeveloped with low- 
income housing. (By 1985, both these last two policy choices would be under attack.)

\section{Mid-1980's Conflicts}

By the mid-1980's the north of Burnside area was represented by strong-willed advocates who clearly represented divergent interests. The social service agencies were represented by Don Clark, at the newly renamed Central City Concern (formerly Burnside Consortium); Jean DeMaster at Burnside Projects; and Michael Stoops at Burnside Community Council. Central City Concern was the establishment's agency. Its nine-member appointed board was comprised of three city positions, three county positions and three Burnside resident slots. Burnside Projects was a more traditional agency which heavily relied upon government grants. Burnside Community Council was the grass-roots independent agency. BCC relied upon government grants for only 20 percent of its budget. Of the three, Central City Concern was most in synch with Mayor Bud Clark. As early as February 1985, Don Clark proposed a "coordinated service delivery plan" including many of the features that would ultimately be folded into official social service policy.

A pro-active housing policy was crucial to keep Burnside social services and housing from extinction. The building code threatened many units. Shelters were not meeting health sanitation codes. In 1983 an Emergency Services Task Force disbanded after failing to implement recommendations for coordination. Elaine Cogan, a PDC board member, warned about duplication and lack of coordination on Burnside. Burnside was becoming a meaner street; 
an increasing number of the mentally ill were being thrown on the street because of the state's deinstitutionalization program. Then crack and other drugs hit during the Reagan administration. The high hopes of the 1970s for a new Georgetown north of Burnside were destroyed first by the recession and then by the shifting character of Old Town's low income population. Northwest Third and NW Couch became a center of the drug trade. The bike shop at the corner moved out. Other businesses had come and gone but the owner had made the notorious drug trade at the corner of NW 3rd and Couch a public issue.

Small property owners were upset over the behavior of street people. In 1985, the Bureau of Licenses, responsible for making recommendations on liquor license renewals to the state, proposed a ban on fortified wine in Old Town. The Council's subsequent action implementing this policy angered surrounding neighborhoods who feared an influx of inebriates. Business people in the Central Eastside were especially angered. The Baloney Joe's shelter operated by BCC had already been forced to move to the east end of the Burnside Bridge when westside business people informally organized to prevent Baloney Joe's from leasing new space on the west side.9 The fortified wine ban looked like another effort to push Burnside area problems onto other districts.

\section{Mayor Clark's 12-point Plan}

Bud Clark, who had raised the issue of homelessness in his successful mayoral campaign, brought Dan Steffey into City Hall. Steffey had been a newspaper reporter and then administrator of a 
workshop for the disabled. Steffey was representative of the mayor's staff in that Clark brought in people whom he personally picked, who did not have long-standing ties with established powers, and who had not served on the relevant citizen committees. Steffey coalesced proposals of Don Clark with Bud Clark to create an integrated package of social services and policing policies to complement the replacement housing program.

In December, 1985, Mayor Clark proposed the purchase of the Estate Hotel at 225 NW Couch and the Beaver Hotel at 506 NW Fifth Avenue (see Figure 38). The Estate, then rented by Central City Concern, would continue as a 162-room SRO with 55 fourth-floor rooms for recovering alcoholics. The Beaver would become a social service center for transients and the homeless. This was the first test of the Mayor's campaign pledge to help the homeless.

The business community tested the mayor in his resolve. The proposal drew immediate opposition from the two-month old Union Station Business Community Association. The leader of the opposition was C. Joseph Van Haverbeke, a building owner and developer with offices at 406 NW. Glisan Street. Van Haverbeke drew support from Naito property interests, although Bill Naito merely suggested transporting the transients to the Pacific International Livestock Exposition building on Marine Drive rather than putting them on a ship/detention center in the Willamette as Van Haverbeke suggested. Naito was on record as supporting the purchase of the Estate Hotel although he also signed a protest petition along with the gas company and a couple hundred business 


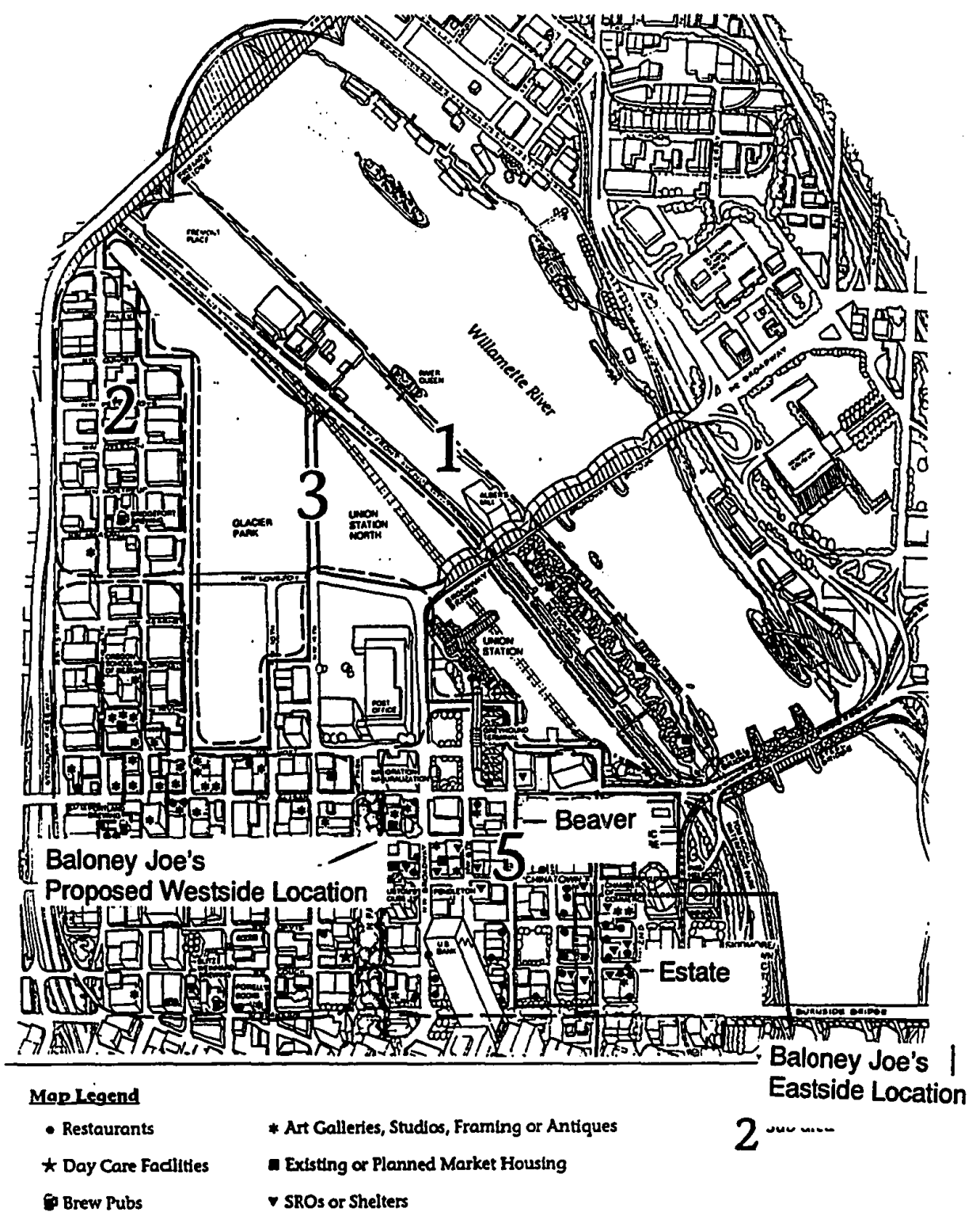

Existing Characteristics

Figure 38. Location of SRO's or Shelters North of Burnside. From City of Portland, North Downtown Development Program (1990). 
people. The purchase of the Estate was one of 12 recommendations put forth by Steffey and Clark:

1. Provide case management services to help guide the homeless through the social service network;

2. Acquire the Beaver as the access point where the homeless and transients could obtain basic services. Funds would come from the federal government, tax increment financing, the Wessinger Foundation, the Collins Foundation and the Rose Tucker Charitable Trust;

3. Develop a social service plan to define social service needs and to recommend ways to divide responsibilities among agencies, the City and Multnomah County. (This would accomplish what the old Burnside Consortium had failed to do.);

4. Adopt a housing plan to use vacant hotel rooms and Portland Housing Authority emergency housing and establish a unified city-state requisition system for housing vouchers;

5. Create a public camping area within freeway rightsof-way with supervision and sanitary services (on the back burner due to opposition from eastside interests and reluctance by the Oregon Department of Transportation).

6. Establish a "man down" response system in which one agency would pick up public inebriates;

7. Develop new programs through Multnomah County to meet the needs of drug and alcohol abusers;

8. Lobby for changes in state law to provide for involuntary commitment of chronic alcoholics involved in a "revolving door" use of detoxification;

9. Provide pissoirs in Old Town; 
10. Encourage private employers to offer minimum wage jobs to Burnside residents and work with the Association for Portland Progress on a jobs program for the poor;

11. Prohibit dumpsters on Old Town sidewalks and develop a trash system, using low-income persons to haul trash to a central location; and

12. Establish a pilot neighborhood team police unit north of Burnside. The unarmed police aides would serve to assure the area of a police presence and would increase public safety.

It was clear that this was to be a major fight. As the Oregonian commented:

The rift between businesses and social services providers threatens to irreparably damage the fragile mixed residential and business community that has developed north of Burnside and in the Skidmore Fountain district over the past two decades. There is general agreement that construction of a convention center north of Old Town, if that site is chosen by the City Council, would exacerbate the conflict, and a growing fear that privately operated low-income hotels remain threatened. by age and development pressures." 10

Soon afterwards, the Mayor met separately with social service agencies and business people. The Mayor's press secretary, Jack McGowan, emphasized to the public that the goal of the program was to return the homeless to productive citizen status, thereby reinforcing community standards.

Peter Paulson of Northwest Pilot Projects, who had co-chaired the 1981 North of Burnside study, supported the program. C. Joseph Van Haverbeke, the other chair of the study, did not. The business community saw this proposal as a setback in their attempts to drive 
the social service agencies out of Old Town. Louis Waschmuth, who owned property two blocks south of Burnside, installed drip lines around the perimeter of his restaurant to regularly drench transients who might be loitering by his building. Van Haverbeke called for the Mayor's recall.

In August of that year, public officials Mayor Clark, Dan Steffey, Pat LaCrosse, and Don Clark brought representatives from U.S. Bank, Northwest Natural Gas, Pacific NW Bell and Vern Ryles from CEIC to Seattle for a tour of the program there. At dinner at the Washington Athletic Club, the big property owners were brought on board, at least temporarily. Radicals like Michael Stoops ${ }^{11}$, who was running a progressively larger and financially fragile social service agency and small business people grouped together in the Union Station Business Community Association were not invited.

The Beaver/Estate proposal required an amendment to the Downtown Waterfront Urban Renewal Plan. The Union Station Business Community Association continued to fight the proposal. The Association proposed locating any shelter in an industrial zone in the Stenger building at 77 SE Taylor. Arguments were made to Council that additional social services would increase transient populations and make the area permanently blighted, would cost too much, would cause crime, and social service providers simply benefited from human misery.

Council approved the amendment on January 31, 1986. The merchants appealed the matter to the state's land use appeals court. 
Although the Land Use Board of Appeals remanded the issue back to the City, the hotels were eventually acquired.

The City and County also agreed to meet in a joint session to consider a revised version of the 12-point plan. A 65-member CityCounty Emergency Basic Needs Committee was organized to create a comprehensive plan to coordinate the delivery of services. The committee would include two elected city officials and two elected county officials, four community representatives and one representative of service providers.

\section{THE CLARK-SHIELS AGREEMENT}

The success of the mayor's 12 Point Plan meant that the area north of Burnside would provide a system of social services in tandem with a range of low-cost housing from shelters to independent living. Small businessmen were impatient and did not grasp that the eventual intent was to eliminate the shelters in favor of residential SROs with mandatory rehabilitation program.

Large property owners and businessmen were also frustrated by the lack of progress toward redevelopment in the North of Burnside area. The Convention Center's location at the east end of the Steel Bridge and the potential for railyard redevelopment (Glacier Park) meant great potential, but nothing was being realized. North of Burnside business people felt that the unsavory character of their area was frightening away potential investment. This was an accurate assessment as the eventual loss of the Oregon Museum of Science and Industry (OMSI) to the Central Eastside and the State 
Office Building to Lloyd District would attest. Private consultant Roger Shiels was hired to represent U.S. Bank, the gas company, and the big property interests such as Hillman and Naito. (Shiels was joined by Doug Obletz who had shepherded both the Rouse project and the Transit Mall to completion.) The business agenda consisted of extending the Transit Mall, relaxing development regulations as part of the Central City planning effort, and limiting social service agency expansion. The firm of Shiels and Obletz was able to "shift" funds around in order to get the Transit Mall work going. This was crucial work as the last of the funds associated with the Banfield light rail project were due to expire.

Also, the Central City Plan was amended to significantly increase floor area limits. This was done by increasing the number of blocks with 9:1 floor area ratios from one to fourteen blocks. Also, there is now a built-in guaranteed 3:1 bonus for corporate prestige items such as art and water features. With this bonus system, the minimum floor area allowance north of Burnside is 7:1. Areas along the transit mall enjoy development permission equal to most areas south of Burnside.

However, these public works and permissive zoning regulations have come at a price. In order to push the transit mall through without public opposition, negotiations were held with Don Clark who represented the social service agencies. Beginning with lunch at the Marriott and continuing in the Mayor's office, both sides agreed on the followinc principles: 
1. Preservation and upgrading of existing SRO housing to provide decent, safe and well-managed accommodations for all low- and zero- income persons living within the District.

2. Continuation of services which support the permanent low-income and zero-income persons living in the District including employment, health, nutritional and personal services.

3. Continuation of emergency shelter and related services for the homeless at current levels, while seeking to eliminate the need for these services by assuring that adequate permanent housing, jobs and support services are provided community-wide.

4. Acceleration of economic growth of office, retail, restaurant and visitor oriented commercial activities while preserving and building upon the district's unique assets including improving the District's image.

In order to simultaneously promote housing and services which served the poor and to "accelerate" economic growth and improving the District's "image" (the euphemism for getting the bums off the streets), the private agreement strictly limited the number of shelter beds to those run by the Portland Rescue Mission (52 beds), the Glisan Street Multi-Service Center (150 beds) and the Union Gospel Mission (50 beds). SRO beds were limited to 1030 units - the existing occupied SRO units (803 units), plus SRO units vacant since 1978 (227 units). Additionally, as shelter beds were permanently removed, these beds could be replaced by SRO units.

There were two very important results of the agreement. First, Baloney Joe's could not return to the westside, nor could other agencies increase their shelter capacity; and second, all SROs would 
eventually be under public control though conditional use review and funding. Subject to city public review, proposals could now be turned down.

The Council blessed this private agreement by passing Resolution 34286 on May 13, 1987, commending "the initiative of the represented property owners and non-profit social service representative .... for their commitment to resolve past conflicts and seek cooperative solutions which support low and no income persons living North of Burnside while also accelerating economic growth."12 The Essential Service Provider (ESP) provisions were adopted into the zoning code through a process of adapting the on-going Central City Plan process to meet the needs of the parties involved. The proposed draft Central City Plan zoning had proposed to require that social service agencies apply for conditional use approval. These code provisions had been suggested by PDC. At the direction of Dan Steffey and Roger Shiels, staff revised the language to develop different levels of approval criteria depending upon the distance between the ESP facilities in order to reduce the impacts of social service concentrations. Don Clark presented the ESP amendments to the Planning Commission at the first public hearing regarding amendments to the Proposed Plan (November 5, 1987.) At the November 10, 1987 hearing, Richard Meyer, who had moved from the Planning Bureau to Burnside Community Council, and BCC attorney Ed Sullivan argued that the distance criteria would make all applications subject to appeal. The Planning Commission, when faced with a choice between removing distance criteria or allowing 
the application to be subject to appeal, chose the latter. Commissioner Lindberg supported the agreement and clarified that the regulations would be applied only to food and shelter providers. Council also accepted the request by Roger Shiels that the SRO and shelter bed limit be placed in the code rather than being a policy consideration. The request was made without the Council being aware that the social service agencies expected this to be merely a "gentlemen's agreement."

The Central City Plan SRO cap north of Burnside, 1030 units, theoretically meant that Burnside Projects was required to eliminate about 30 shelter beds in the Glisan Street shelter in order to open the Shoreline residential hotel. However, Legal Services challenged the constitutionality of the code provision and it is not currently being enforced.

At the adoption of the Central City Plan, the low-income housing supply was 900 units less than the downtown housing policy goal of 5,183 units The Golden West, Foster, Sally McCracken and Shoreline hotels were rehabilitated north of Burnside before the SRO lid was reached. This shortfall is proposed to be made up in the remainder of the Central City. The area west of SW Park Avenue and south of Burnside contains the only other low-income area specifically called out by the Central City Plan. With north of Burnside and south of Burnside "full-up," Mayor Bud Clark and Commissioner Earl Blumenauer directed PDC to start looking elsewhere for new low-income project sites. PDC was pushed to expand its South Park Blocks urban renewal district and start using 
public money to go beyond its previous middle-income projects. PDC extended the South Park Blocks urban renewal district to include this area and promised to use tax-increment financing for rehabilitation and renovation of housing units. This new approach reflects a change of policy for PDC. With the adoption of the ClarkShiels agreement and its incorporation into the Central City Plan, the business community accepted a small residential program to be run by PDC. The Downtown Housing Preservation Program, or DHPP, was adopted in 1988 . Its budget was $\$ 2.6$ million annually, or $\$ 7.8$ million over three years to produce 450-750 units. The project projected a gain of 482 units by the end of 1991 .

South of Burnside, PDC undertook the renovation of the Henry Building to house downtown workers with low incomes. U.S. Bank was opposed to the renovation as it was feared that the City would begin rehabilitating low-income housing south of Burnside where no cap was in effect. However, PDC criteria, (“...availability, building size, development cost," etc.) eliminated potential activity south of Burnside.

The necessity of PDC involvement and the use of tax increment. financing was demonstrated in the spring election of 1989 when voters overwhelmingly defeated a measure to permanently fund housing for the poor. The Building Owners Managers Association (BOMA) led an overwhelmingly successful campaign against a proposed real estate title transfer fee. The 0.15 percent tax would have provided \$2.3 million per year. BOMA and the Homebuilders Association created a "Committee Against the Real Estate Sales 
Tax" successfully changing the ballot title from fee to tax and opposing not the principle of helping the homeless but a system of "patchwork taxation." The measure went down 93,055 to 29,341.

\section{CENTRAL CITY PLAN POLICY REVERSAL}

In addition to institutionalizing the Clark-Shiels agreement with caps and public approval requirements for shelters, the Central City Plan marked the end of the former spirit of laissez-faire north of Burnside.

First, the Plan specifically repealed the 1981 North of Burnside policy. The issue of supply and demand for land was turned on its head. Instead of concluding that there was plenty of land elsewhere than the North of Burnside District, the plan advertised "redevelopment potential." North of Burnside had two-thirds of its area available for redevelopment

Secondly, as previously mentioned, major upzoning specifically raised FAR limits from 9:1 on one block to 9:1 on 14 blocks with a height limit of $460 \mathrm{ft}$. south of Everett along the transit mall. (Figure 39 illustrates the greatly increased floor area zoning regulations north of Burnside.) The FAR limit itself could easily be increased by $3: 1$ so that the most restrictive floor area limit became 7:1, more than twice the existing development pattern. Central City Plan Finding \#137 justified the "re-examination" of FAR limits based on the Clark-Shields agreement; finding \#139 stated that 6:1 FAR is inconsistent with extension of the Transit 


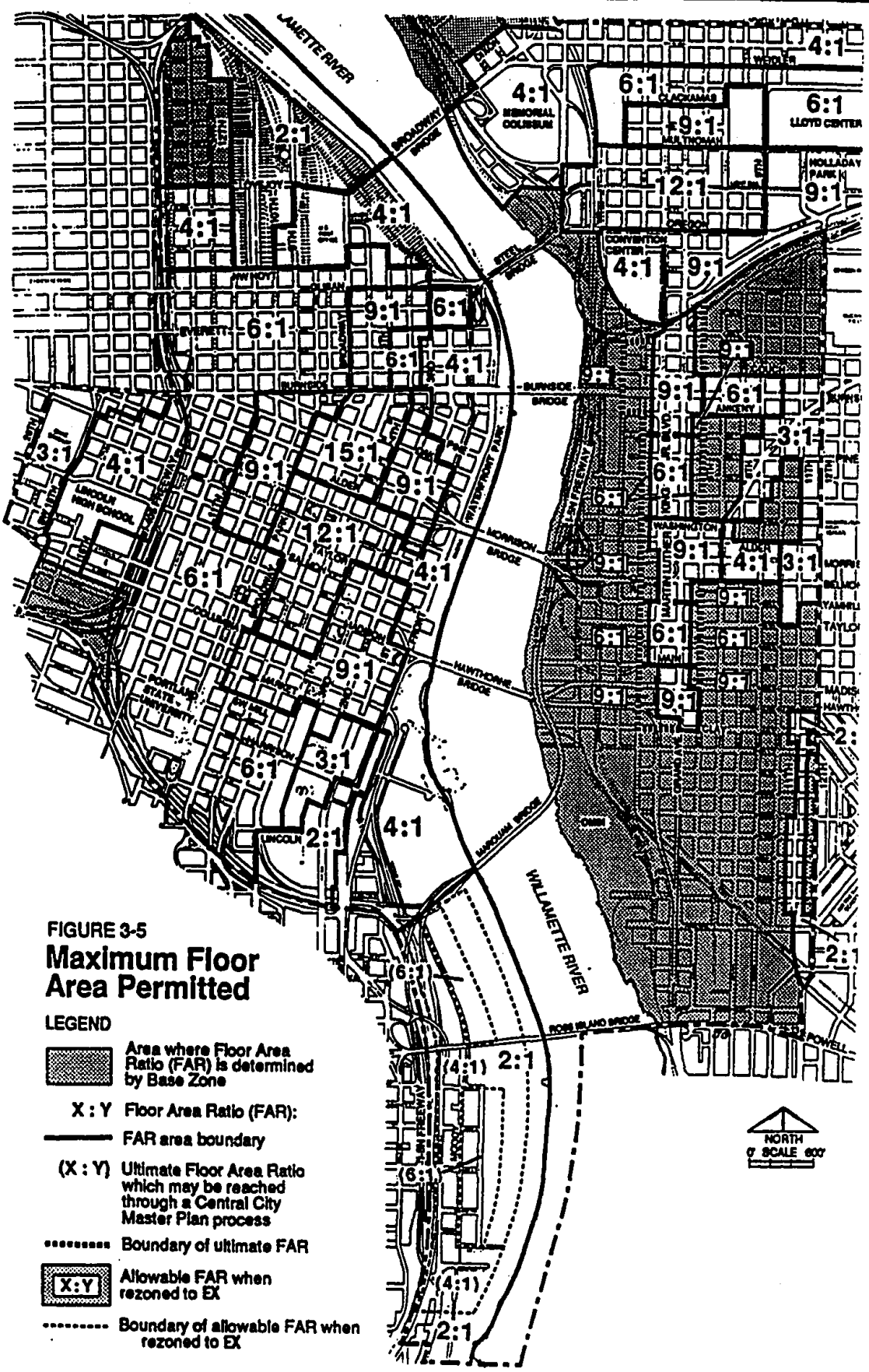

Figure 39. Central City Floor Area, 1988. From City of Portland, Developers Handbook (1992). 
Mall (a finding which contradicts the 1981 North of Burnside implementation report - finding \#3).

Thirdly, the plan sanctioned the Clark-Shiels agreement, including the extension of the transit mall and the redevelopment of Union Station. The challenge of $B C C$ to the urban regime and the social service agency, City and business community counterreaction deserves a separate section. If there was to be a compact, there had to be a penalty for disregarding' it.

The Burnside Community Council Closes

An examination of the fate of $B C C$ once it decided to ignore the Clark-Shiels agreement and the Central City plan and relocate to the westside provides the clearest example of the strength of the urban regime.

The BCC was originally organized in 1974 as the Burnside Neighborhood Committee, an official Portland city neighborhood. In 1976, Michael Stoops arrived as a Vista volunteer; he conceived of and worked at a day shelter on Couch Street. In 1981, BCC moved its shelter, Baloney Joe's, to the east side of the Burnside Bridge. BCC began the Hobo parade. This parade mocked the City's Rose Festival by replacing the Rose Festival Queen and her court with the more colorful transients of skid road. The Burnside Community Council decided in August 1986 that the shelter was inadequate. And, BCC had been severely criticized for allowing homeless men to congregate on the Burnside Bridge waiting to get in the door. Michael Stoops bought a property at 725 NW Flanders in a blind sale. The City and business community were outraged because this meant 
that the City's plan to upgrade the area west of Broadway would come to naught if day shelters moved to the area and scared potential residents and businesses away.

This area west of the North of Burnside area had been renamed the Northwest Triangle. The dividing line was the Park Blocks south of Hoyt to Burnside. The blocks adjacent to the North Park Blocks and a newly formed historic district along NW 13th Avenue were slated for massive upgrading in hopes of creating a Portland SoHo. In 1983, the City of Portland Planning Bureau had completed a comprehensive study of the Northwest Triangle following an AIA study of the area in 1983. The Planning Bureau collaborated with the Northwest Triangle Business Association to produce a plan which provided momentum to upgrade the North Park Blocks, build new streets and create an historic district. Before long the area was marketing itself as the "Pearl District" -- that is, still grubby on the outside but an exciting arts environment within restored warehouse spaces. The Central City Plan codified the work of the last half-decade to redevelop the area. The Central City plan rezoned the area and called for an urban renewal district, a cultural development area, floor area bonuses for housing, and regional public attractions (and even microbreweries!) ${ }^{13}$

$B C C$ found itself in increasing difficulty with the City and downtown business community as it attempted to move to $725 \mathrm{NW}$ Flanders on the North Park Blocks. In December, 1987, Mayor Clark visited a BCC Building Committee meeting and requested that $B C C$ reconsider its options. PDC was recruited to spot alternative sites 
on the eastside. In April, 1988, the Oregonian criticized BCC for its too ample "cash reserves." In May, 1988, the mayor cut $\$ 25,000$ from BCC's budget. In June, 1988, the Flanders site financing loan was turned down by U.S. Bank. In November, 1987, Willamette Week weekly newspaper accused Michael Stoops of sexual misconduct with one of his juvenile clients. In November, 1988, Mayor Clark publicly announced his opposition to the Flanders site, vowing public condemnation if necessary. 14 The Stoops affair had doomed the agency. The agency was ultimately forced to hand over operations to the Salvation Army. The shelter remained at the east end of the Burnside Bridge despite the $\$ 350,000$ spent by $B C C$ to renovate NW Flanders. An analysis, written by BCC's bookkeeper, Gene Ediger, illustrates the isolation of those bucking the consensus reached during Clark's tenure. Ediger wrote in an Oregonian opinion piece that BCC was done in by a variety of factors - the resignation of Stoops; the increasingly negative media coverage; naivete on the part of BCC in dealing with the City, the banks and other property owners; and Mayor Bud Clark. Dan Steffey, speaking for the City, rebutted that the bad press was deserved; that BCC got its just desserts in rejecting the Clark-Shiels agreement; and that BCC was not willing to participate in an open discussion, a condition of the Mayor's support. 15

There have been a few protests since the destruction of BCC. As previously mentioned, Legal Aid challenged the shelter limit zoning code provisions under the Fair Housing Act. And Jeff Liddicoat and New Clear Vision staged a camp protest on land 
opposite the South Waterfront project in 1991. However, the camp was eventually cleared. And when Mayor Clark allowed protesters to camp across the street from the Courthouse to protest the lack of a public campground, the Oregonian expressed indignation that the protesters had not been rousted immediately.

\section{CHALIENGE TO PDC}

As part of an on-going struggle to deploy resources more effectively, Portland, Multnomah County, the Housing Authority and United Way retained a consultant, Barney \& Worth, to report on duplication and wasted effort in the delivery of housing services. Barney \& Worth's report called for a "county-wide joint mechanism that is responsible for county-wide housing policy, planning, advocacy and coordination." The Chamber and the City/County oversight committee reviewed the report and called for a consolidated policy and planning committee. In the fall of 1989, the City and County created a five-member City/County Housing Management Plan Development Council. It was comprised of Mayor Clark, Multnomah County Chair Gladys McCoy, City Commissioners Blumenauer and Bogel, and County Commissioner Gretchen Kafoury. These elected officials delegated the work to a group of City, County and Housing Authority employees. Their charge was to propose "a consolidation of housing-related agencies and organizations under the jurisdiction of the City of Portland and Multnomah County to be reviewed for inclusion in the consolidation of all agencies, organizations and operations units which carry out housing related 
functions." The technical group decided to recommend that the City and County HCD agencies, the Housing Section of PDC, the Housing Authority and the Planning Bureau's housing planners be merged by June 30, 1990. Furthermore, the remainder of PDC would be merged "within two years to create a county-wide housing, community development and urban renewal agency."16 This latter proposal was tantamount to abolishing PDC and the basic businessmen's premise that PDC's most important function was economic development.

The proposal was dead on arrival. The news was leaked to the press before the recommendation could be delivered. Front page headlines and business objections immediately killed the proposal. At the Housing Management Plan Development Council Meeting on January 18, 1990, Gladys McCoy began the meeting by killing the concept. She was seconded by Gretchen Kafoury and Bud Clark and Earl Blumenauer. The Chamber of Commerce objected that a functional study had turned into a organization study. Not only had PDC turned back the most direct assault on its organization, since the OPD study in the late 70"s (the Marriott tennis court deal), but Pat LaCrosse fired the PDC liaison to the technical group. Don Clark's and Dan Steffey's initiative had failed.17

\section{RIVER DISTRICT PROPOSAL}

In March, 1992, private business collaborated to lobby City Council on a proposal for a major city redevelopment focus on the railyards located just north of NW Hoyt Street at the west end of the Broadway Bridge. (See Figure 40. The parcels are marked Glacier 


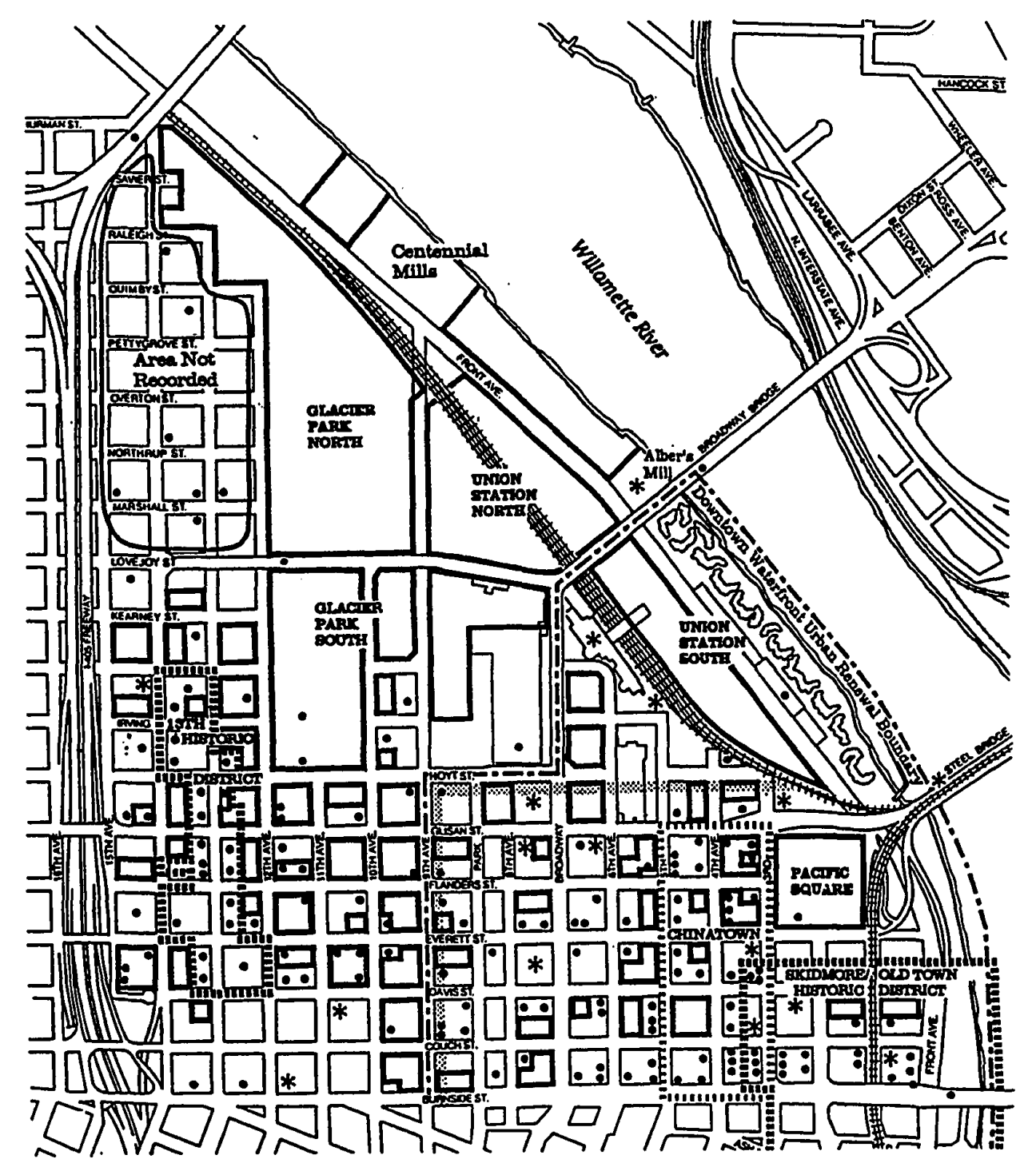

Q Strong Redevelopment Potential

* Historical Landmarks

- Potentlal Landmarks/Rank 1,2 and 3

Historical Inventory/Primary and Secondary

Contributing Fistorical Bulldings

Figure 40. North Downtown Redevelopment Opportunities, 1990. From City of Portland, North Downtown Development Program (1990). 
Park, Union Station and Centennial Mills.) The owners of the railyards wished to collaborate with PDC in creating a new upscale, pedestrian district adjacent to the light rail crescent. The River District is the linchpin in the City's effort to redevelop the light rail crescent. The River District would also put Old Town in the center of redevelopment with the River District to the north, the Northwest Triangle district to the west, downtown to the south and the Blazer arena/Lloyd District to the east. The River District was a capstone to City efforts to create an effective "North Downtown" strategy. The strategy would replicate the South Auditorium effort:

... in that case, two clearance urban renewal areas, once developed, served as a magnet to pull the traditional downtown southward. The land between was redeveloped with office and housing uses with minimal public investments. For North Downtown a similar strategy is possible, with the advantage that the railyards provide already cleared development sites. The difficulty with North Downtown is the public perception of the area as generally unsuitable for development. The City's intent to maintain both the historic structures and the SRO housing increases the difficulty of overcoming public perceptions. ${ }^{18}$

\section{CONCLUSION}

An examination of the outcomes illustrated by Figure 41 indicates the absolute connection between the increasing economic importance of this once-peripheral district and the downtown urban regime's increasing control of public development policy. Planning documents labeled the area skid road in the 1960s; followed by Union Station/Railyard in the 1970s; North of Burnside in the early 


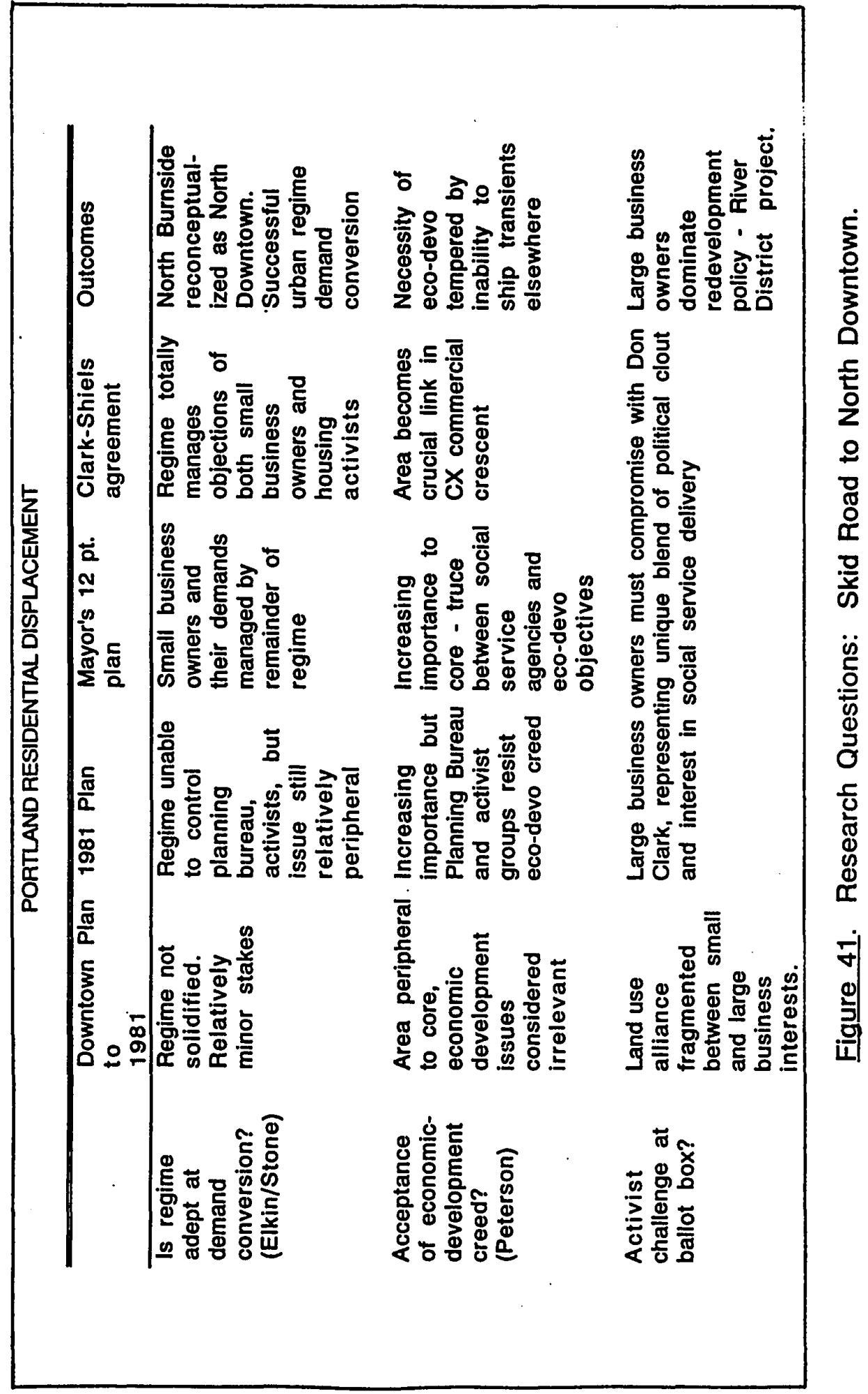


1980s; and most recently, North Downtown or the River District. These names indicate how this area moved from the northern periphery of the westside downtown to the central position in today's light rail crescent of development. As the area has become increasingly central to core development, the area has been renamed, and reconceptualized, as activists' demands lose ground. At each stage, the urban regime was confronted with the presence of transients, displaced workers and seasonal workers and those social service providers who served them who could not be displaced elsewhere.

The Downtown Plan reshaped the westside core and excluded skid road habitués from areas south of Burnside. Furthermore, the plan proposed to extend the Transit Mall and provide redevelopment opportunities at the same time it acknowledged the critical loss of housing. Throughout the 1970s, the City unsuccessfully attempted to balance these competing policies. The City advanced an organization, Burnside Consortium, which brought together the more prominent members of the urban regime and which excluded the radical activist, Michael Stoops. But, the 1981 North of Burnside Plan brokered five major interests who disputed whether the area would remain a backwater skid road, or a revitalized and historic small business community, or a redeveloped northern extension of downtown. This was a high stakes conflict in which the Planning Bureau under Commissioner Strachan played an unusual social activist role. The Bureau restrained pro-growth local businessmen by actually lowering floor area ratios. In contrast to the Central 
City Plan Experience described in Chapter III, the Bureau was able to recast PDC's research to demonstrate that the area north of Burnside was not crucial to the downtown retail and office market. The economic development argument was examined and found wanting. Thus, district pro-growth activists were isolated from the westside business establishment centered around the retail/office core.

Mayor Clark's 12 Point Plan attempted to finally implement the Downtown Plan in a decade when divisions between pro-growth interests and social activists had been exacerbated. The recession and growing street crime threatened both residents and potential customers. Planning for a new convention center north of the area or across the river signaled that the area was no longer isolated.

The City's developmental policies, its economic stake in the convention center, and the question of Burnside were no longer disconnected policy issues. The new geography meant that the stand-off could not continue. The construction of light rail and the extension of the Transit Mall (begun in 1993) favored redevelopment. The construction of the Convention Center across the river and the railroad's divestiture of Union Station and the railyards created a powerful magnet for new investment. The Central City Plan provided the means to change public policy. Just as the Downtown Plan's initial success created the demand for the Central City Plan update, the experience with the South Auditorium district suggested a model for a mirror River District. The South Auditorium urban renewal area was Portland's unchallenged economic development success 
story and the warnings that might have been heard by an objective historian of displacement were very faint.

Both the Central City Plan shelter restriction and the River District proposal were approved by City Council in public hearings. But these decisions were fundamentally private negotiations. The Shiels-Obletz consulting firm represented pro-growth private property owners at the same time it helped the City save federal funds for the Transit Mall extension. Total victory for private progrowth interests was averted only by the fortuitous position of Central City Concern director, Don Clark. In this case, Don Clark exercised a unique blend of political clout and interest in social service delivery. Otherwise, activists were unable to mount a serious challenge to downtown interests.

Institutional arrangements for the North Downtown/River District development program now being put in place will ensure redevelopment and displacement of many of the poor when the real estate market turns around.19 Of the five groups contesting public policy in 1981, large property interests completely dominate development policy as the City pursues its North Downtown crescent strategy. Only the inability to ship the transients elsewhere constrains the urban regime. 


\section{ENDNOTES}

${ }^{1}$ City of Portland, Housing and Downtown Neighborhoods. Documentation of 1980 Housekeeping Amendments to Planning Guidelines/Portland Downtown Plan Retitled Goals and Guidelines/Portland Downtown Plan, As Adopted by the Portland City Planning Commission, August 5, 1980, exhibit "B" , p. 9 of Resolution 32772, adopted by the Portland City Council, October 1, 1980.

${ }^{2}$ City of Portland, Planning Guidelines. Portland Downtown Plan, pp. 26-27.

3irving W. Shandler, "Portland Oregon Skid Road Project: Social Policy Recommendations," Diagnostic and Rehabilltation Center, Philadelphia, attached to "Social Policy Report for the Downtown Urban Renewal Area," Human Resources Bureau, City of Portland, November 24, 1974, pp. 87-125.

4Members included Bill Wessinger, business executlve; Richard Cohn, Vera Katz, Oregon House of Representatives; Bill Lindsey, head pastor of First Presbyterian Church; Reverend Joseph, pastor of First Lutheran Church; Jim Atwood, a real estate agent; Edith Sherman, housing activist; Mary Burki, housing activist; and the manager of the Ambassador condominium.

${ }^{5}$ City of Portland, Downtown Housing Advisory Committee, "Downtown Housing Policy and Program," Adopted by the Portland City Council, October, 1979.

${ }^{6}$ City of Portland, Oregon, "North of Burnside Land Use Policy," Adopted by the Portland City Council, May 14, 1981, Ordinance No. 151568. pp.1-2.

7Ordinance No. 151568, findings $4(a)$ through $(f)$.

8Leland and Hobson Economic Consultants, "North of Burnside Study: Analysis of Economic Impacts: Assessment of Development Potentials," September, 1980, pp. 113 and 122.

9Richard Meier, interview, February, 1991.

${ }^{10}$ Oregonian, "Mayor's Plan Splits Agencies " December 3, 1985 (This was the first public draft of the plan in a slightly different form.) Oregonian, "Most at hearing balk at plan for homeless," February 25, 1986.

${ }^{11}$ Stoops called the plan the Yamhill Market "boutique" approach to homelessness.

12Don Clark, Roger Shiels, "Memorandum of Intent", attached as "Exhibit 'A'" to Resolution 34286, adopted by Portland City Council on May 13, 1987.

${ }^{13}$ American Institute of Architects, Last Place in the Downtown. Central City Plan Policy 17: Northwest Triangle Action Chart.

${ }^{14}$ Burnside Community Council, "Flanders Siting Background," no date. The author quizzed several knowledgeable individuals as to the truth of this chronology. No rebuttals were forthcoming. 
${ }^{15}$ The following individuals are most knowledgeable: Don Clark, Roger Shiels, Sam Galbreath, and Richard Meier.

${ }^{16}$ Adriana Cardenas, Housing Advisory Group, "Interim Report on the Housing Management Plan", p. 2.

17 Minutes Housing Management Plan Development Council Meeting: 7:30 AM, January 18, 1990.

18Steve Dotterrer, Office of Transportation, City of Portland, "Draft Memorandum, North Downtown Strategy," . May 26, 1987.

- 19 In 1988, Mayor Clark's office issued its own call to manifest destiny: "The geography of Portland with its rivers, hills, and fully developed residential areas to the south, west and east makes North Downtown the only area in which the city core can expand. The choice is to grow into North Downtown, or quit growing." Office of the Mayor, City of Portland, "Breaking the Cycle of Homelessness: The Portland Model," Revised September, 1988, p. 12. 


\section{CHAPTER VIII}

\section{RESIDENTIAL DISPLACEMENT IN DOWNTOWN SEATTLE}

To his credit, he [Royer] was willing and able to commit money, to find money to build housing, and to provide services to the poor. On the other hand, he pushed policies to redevelop the city, even though the impact of that contributed to the loss of hundreds and hundreds of low-income housing - much more than we could ever build. The Development community has been the beneficiaries of his policies. Look at downtown as testimony to that: three to four-hour rush hours in the afternoon. He had opportunities to control those forces and he didn't.'

John Fox, Seattle Displacement Coalition

\section{COMMUNITY REACTION TO INCREASING DISPLACEMENT}

During the 1960s and 1970s code enforcement and demolition for large-scale public projects contributed to the loss of downtown housing, even as the gap widened between potential and effective demand for housing. Between 1960 and 1974, half the supply of downtown housing was lost - 16,251 housing units in 393 buildings. The business community recognized the loss as early as the 1960 s. The Downtown Seattle Development Association (DSDA) organized an In-Town Living Committee in that decade. The In-Town Living Committee set a goal of 50,000 additional units between 1970 and 1980. Yet by 1974, only 1,163 new units had been constructed; it was then estimated that commercial re-investment was pushing 
1000 people from Pioneer Square to areas adjacent to Pike Place Market and the area between Westlake and I-5 (See Figure 42). In 1974, the Skid Road Community Council asked Seattle City Council to develop a short term strategy for downtown housing. In 1976, the Council created a task force to rehabilitate as many as 31,893 units but only 14 units were ever rehabilitated. The following year, 1977, the Seattle Tenant Rights Association proposed that rent control be adopted. Over 4,000 signatures were collected in support. The Seattle Apartment Owners Association opposed the proposal and Mayor Uhlman and the Council unanimously rejected the proposal. The Council created another task force to deal with the newly discovered city-wide redlining phenomenon. The Task Force on Redlining split on fundamental philosophical issues and fair housing issues were dropped for another decade. The City pursued its own strategies based upon federal funding of projects. The Department of Community Development under Mayor Royer was unpopular with the neighborhoods as the promoter of scatter-site low-income public housing.

The Seattle Displacement Coalition (SDC) was formed in February, 1977 to fight high-rise condominium proposals, gentrification, and displacement of local businesses along Broadway on Capitol Hill to the east of downtown. Its first event was a debate between mayoral candidates Paul Schell and Charles Royer on the issue of urban displacement. The coalition was an advocacy group backed by the Church Council of Greater Seattle with offices in the Fremont neighborhood (near the University of Washington campus). 


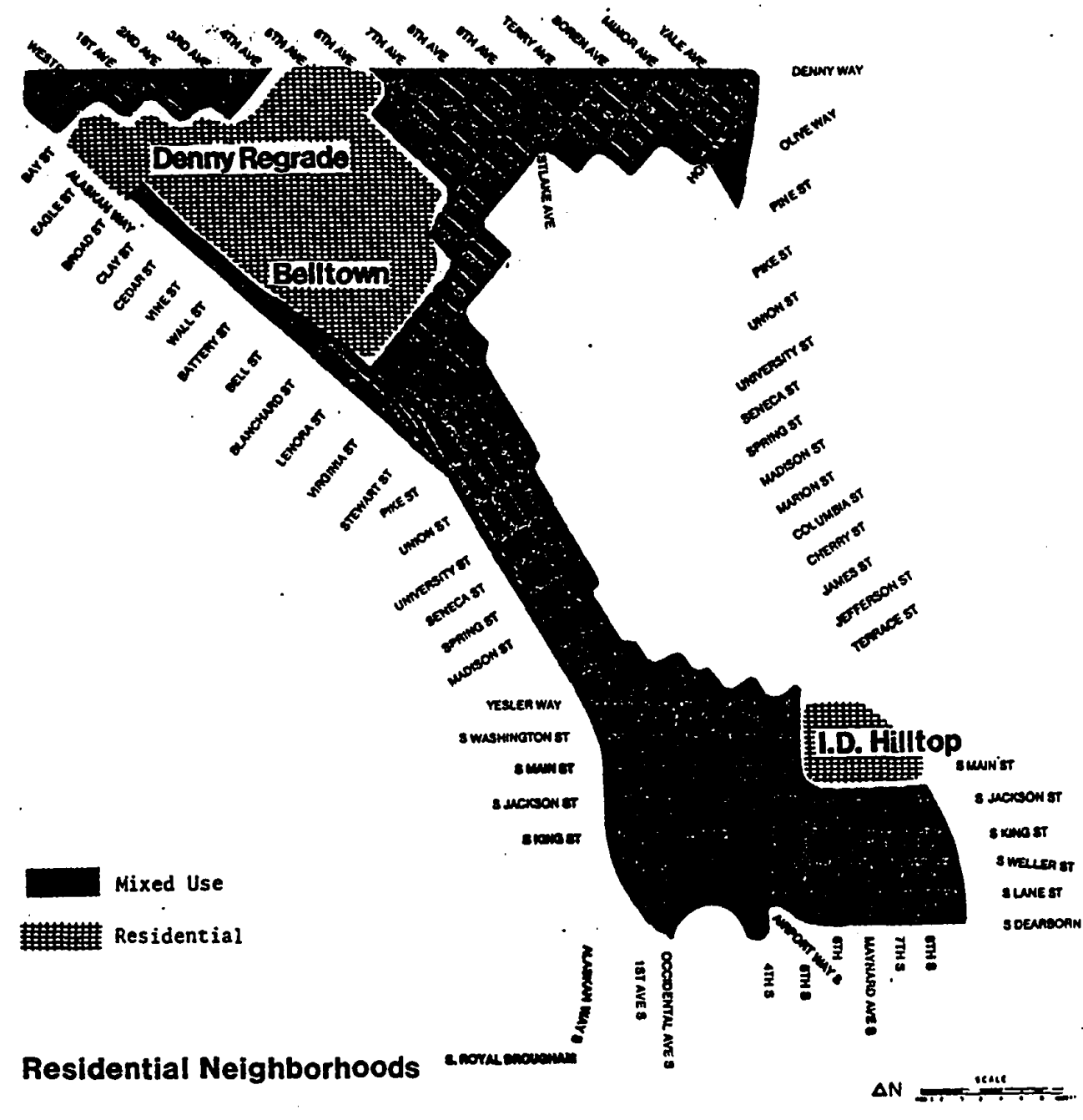

$3 \boldsymbol{A}$

Figure 42. Seattle Downtown Residential Neighborhoods.

From City of Seattle, Land Use and Transportation Plan (1988). 
The coalition testified at hearings, held debates, and met with developers over breakfasts to negotiate. Its strength was its power to delay as well as "overloading" public hearings with 200 to 300 people prepared to testify. The two major forces in the SDC during this study period were John Fox and the Rev. David Bloom. John Fox worked for the Fremont Neighborhood Association before working full time, at $\$ 12,000$ per year, for the SDC "Displacement Project," financed by a grant from the U.S. Department of Housing and Urban Development. Fox is still active in housing issues in Seattle and provided material for this study. Rev. David Bloom is an ordained American Baptist Minister formerly in the University Baptist Church. Bloom is presently active in the controversy over Seattle's huge homeless shelters at Seattle Center. Both activists were disliked by the business community. John Gilmore, then executive vice president of the Downtown Seattle Development Association, now president, called the SDC "againers," people who are "against" anything proposed, in this case, growth or new construction. Of course, Fox responded in a Seattle Post-Intelligencer profile, that wasn't so: "We're for compatible growth that preserves and enhances the existing character and economic and social diversity of Seattle's neighborhoods." There was also friction between city planners and housing activists. City planners accused the housing activists of making deals with developers outside the zoning code and creating "chaos." Fox's view as expressed to the newspaper was that planners made wrong decisions: "Their decisions tend to reflect the special interests." 2 
At this time, in the late 1970s, condominium conversions created the greatest controversy. The Displacement Coalition wanted stronger State Environmental Protection Act (SEPA) impact standards to fight condominium conversions. The Seattle Tenant's Union proposed an immediate moratorium on condominium conversions which was backed by Council member Michael Hildt. As chair of the Urban Development and Housing Committee of Seattle City Council, Hildt drafted a "Housing Policy Plan." This plan contained a number of ideas which formed the future agenda for housing activists: rezoning single family and multi-family parcels, subsidizing developers to build housing, allowing building permits to be denied if people were to be displaced, and requiring maintenance and occupancy of existing multi-family units.

In December of 1978,300 housing activists attended the Seattle Housing Convention and passed a resolution calling for a capital gains tax, rent control and rent stabilization, prohibitions on demolition of multi-family housing, a moratorium on condominium conversion until the vacancy rate rose to 5 percent, and withholding of public moneys from projects which would result in the loss of low-income housing.

Activists rallied at City Hall on occasion, pushing to save particular buildings or emergency housing legislation. The Royer administration sought to increase the housing supply by rezoning the neighborhoods for higher density.

In 1980, the Department of Community Development issued a Downtown Housing Report which made it clear that market forces 
were destroying downtown housing. The conclusions are worth repeating as a snapshot of a crisis situation:

The poor, the old, the alone, live downtown in housing which uniquely meets their needs for low rents and access to services.

The downtown housing stock is quickly disappearing. Over half of downtown's housing, 16,000 units, has been lost since 1960.

The housing for the poor has already been built. When it is. lost it is not replaced. The loss is not only to the individual downtown residents, it is a loss to the City. The displaced people must live somewhere. Housing available under "Government Programs" is not being built at a rate which can begin to meet the need; and fewer units are being made available by Congress because of the expense of subsidy units.

Costs in social, police and health services also increase elsewhere when individuals are unable to find housing. Loss of housing downtown increases pressure in the remaining rental stock forcing rental rates even higher and vacancies lower. Transiency increases. Pressure on social services is great from clients who require assistance with every basic need - food, shelter, health. The downtown housing problem is acute, immediate and is a problem of losing a nonrenewable resource.

The housing crisis affects all Seattle neighborhoods, but it affects downtown most dramatically. The entire City experiences low housing vacancy rates, increasing demand, rapidly rising rents and mortgage payments, scarce vacant land, development pressure, and displacement, which sum up to a very serious housing problem Take these factors and add poverty, the problems and needs of the elderly, central city business growth, deteriorating housing and the result is the very 
severe downtown housing dilemma for which answers are imperative. ${ }^{3}$

\section{HOUSING PRESERVATION ORDINANCE}

The City responded to the housing and political crisis by passing a housing preservation ordinance (HPO). The ordinance required replacement of low-income housing downtown or alternatively, a contribution to the City's housing fund. The housing activists were supported by the Church Council of Greater Seattle and the Catholic Archdiocese. The Seattle Downtown Development Association criticized the proposal as placing an unfair burden upon downtown interests. The HPO barely passed 5-4. The chief sponsor was Michael Hildt. Council members Paul Kraabel, Norm Rice and Randy Revelle also supported the measure. Council member George Benson was the unexpected swing vote in favor, although later he changed his mind and contributed to the weakening of the ordinance. The HPO was considered an emergency measure. Housing downtown was rapidly disappearing.

The symbol of the fight, the Devonshire Apartment building, was to be demolished by developer Martin Selig for an office tower. As the HPO did not prohibit demolition but levied a tax to discourage demolition and conversion of land from residential to commercial, Martin Selig was able to proceed with the project. The cost was $\$ 107$ per square foot and a $\$ 1000$ relocation payment to each displaced tenant. 


\section{Rent Control}

Initiative 24, a rent control measure, widened the issue from the Council to the electorate. The initiative proposed to:

- roll back rents to January 1, 1979 plus an increase equal to half the Consumer Price Index

- establish a board to review further increases

- restrict demolition and conversion of rentals

- hear eviction appeals based upon "just cause" criteria

Rent control was opposed by builders, realtors, brokers, bankers, apartment owners and developers, all organized as the "Washington Coalition for Affordable Housing." The Coalition countered with an alternative package - a bond issue to build 1,000 to 3,500 housing units, city-wide upzonings, and reduction of apartment parking standards. The DSDA came out in support of a bond issue to build affordable housing. Jon Runstad and Paul Schell organized the Seattle Housing Resources Group to provide lowincome housing as alternative to rent control. Mayor Charles Royer refused to support rent control. But he used the threat of rent control to get support of the bond issue from the downtown business community. As Royer later remarked, "I have no problem using rent control as a way of getting housing built in this city." The rent control initiative failed by a 2-1 margin. Opponents spent approximately $\$ 800,000$ to defeat the measure.

The HPO was further weakened when Council member Benson changed his mind. James Mason of the DSDA drafted an amendment to rescind fees if housing were to be replaced within three years. 
The DSDA used the "little guy" argument to claim that small property owners found the tax to be an insurmountable obstacle to expanding and remaining in business, an infringement on property rights. Royer threatened a veto and a compromise was reached whereby the demolition fee was put on a sliding scale based upon the disparity in rent between old and replacement housing. Despite the revision, the resulting compromise was a significant victory for the activists because it institutionalized the City's commitment to interfere with the normal operations of the real estate market. This commitment would become a significant problem for the City in the course of adopting the housing component of the Land Use and Transportation Project downtown plan.

The Seattle Displacement Coalition commissioned a series of reports in 1979 which led to the conclusion that growth itself created displacement throughout the city. The Commission expected that by $1985,30,000$ new jobs in downtown alone would combine with regional growth to create a demand for 20,000 additional housing units in the City of Seattle. Only 7,000 units were likely to be built. Newcomers would be forced to rent and rents would rise between 46 percent to 60 percent Approximately 14 percent to 22 percent of the rent increase would be attributable to increases in downtown employment. 4 This new understanding of growth impacts led to an alliance with energy conservationists to call for limits to growth. The Seattle Displacement Coalition formed the Downtown Neighborhood Alliance to specifically tie zoning allowances with resulting housing, transportation, infrastructure and energy impacts. 
The Displacement Coalition hoped that by forming the DNA, citizen activists could focus on the causes of displacement rather than continually fight brush fires such as the demolition of the Devonshire.

\section{LAND USE AND TRANSPORTATION PLAN HOUSING POLICY}

The background document prepared to facilitate the Land Use and Transportation Plan was ambivalent about the connection between growth and displacement It argued that "growth improves the prospects for achieving the City's goal of more housing in and around downtown. It also makes older apartments and residential hotels in the downtown core more susceptible to redevelopment or conversion to more economic uses." The questions of whether to maintain affordable downtown housing or to relocate housing to the surrounding neighborhoods, what would happen to Skid Road and special population groups, how to balance downtown needs with other low-income neighborhoods, and other issues were presented in neutral theoretical tones: "What proportion of the current lower income residents downtown would prefer to live elsewhere if they could find housing? 5 Despite dire warnings of a housing crisis from Seattle's Office of Long-range Planning in 1979 and the City's Department of Community Development in 1980, the Seattle City Council concluded in December, 1981 that interim controls on growth were not required.

In 1983, the issue was revisited. The Draft Land Use and Transportation Plan called for an additional 4,000-5,000 downtown 
housing units. The plan called for an affordable housing program to maintain the then current stock of 8,671 low-income units (halfsubsidized). Three "options" were identified: an accessory housing requirement, a housing zoning bonus, and an inclusionary requirement for housing as part of commercial projects.

Option \#1 - Accessory Housing Requirement. This program would require that all new commercial development provide housing as an accessory use at the rate of 300 square feet of housing for every 1000 square feet of commercial development. Housing units provided under this requirement could be sold or rented. Housing could be provided on- or off-site and anywhere in downtown through new construction or rehabilitation of vacant structures. The planners estimated that approximately 4000 to 5000 downtown units would be produced over the next 20 years and result in a 3 percent to 5 percent increase in construction costs.

An optional payment to a "Downtown Housing Trust Fund" would build low-income housing. A payment of $\$ 5$ per square foot was estimated to raise $\$ 15$ million, sufficient to build 620 low-income units. Mayor Royer had floated this option in his "State of the City" address that year. The DSDA was vigorously opposed. 
Option \#2 - Housing Bonus. This incentive program would allow additional commercial space in exchange for the provision of affordable housing units. The housing bonus would complement the use of other bonuses, granted for providing on-site public amenities Approximately 800 to 1000 units would be produced at no greater expense than other incentive public amenities. This was the DSDA program; later, both Council members Street and Noland unsuccessfully sought to reshape the program to favor housing over building amenities and to count low-income housing before middle-income housing.

Option \#3 - Inclusionary Housing requirement. Ten percent of all new housing would be required to be affordable to low and moderate-income households. Three to five hundred units would be produced at the expense of a slight increase in the cost of market rate housing and possibly a slight reduction in the number of market rate units built. 6

These options would operate in conjunction with the City's existing Housing Preservation Ordinance (HPO) and transferable development rights (TDR) zoning regulations. The accessory housing program, although officially listed as one of three options was rated vastly more effective by the planning staff in various analyses throughout the planning process. Planners also noted that tax increment financing funding of housing urban renewal programs was 
prohibited by the state. State legislation prevented the City from using the power of condemnation and proceeds from tax revenues to facilitate private development of affordable housing.

The homeless crisis was the most visible housing displacement issue at this time. The Seattle Weekly and PostIntelligencer newspapers published reports calling attention to the homelessness. Panhandling and vagrancy were conspicuous; the DSDA called for a legal ban on panhandling. ${ }^{7}$

Under Washington law, draft and final environmental impact statements were required for each alternative proposal. The impact statement analyzed the proposed policies and actions of city hall planners and alternatives suggested by community participants. These proposals were examined in terms of impacts upon the housing supply, mitigation of impact, and unavoidable impact. The Draft Environmental Impact Statement for the Land Use and Transportation Policy, released in October, 1983, contained a complicated section on the plan's expected impacts on housing demand and supply. The impact statement analyzed five basic alternatives: (1) the proposed action by planning staff; (2) the Allied Arts/Department of Community Development/Denny Regrade proposal; ( 3 and 4) two alternatives based upon theoretical models of "Limited growth" and "Regional employment center;" and (5) no action. The planning staff's proposed action included accessory housing requirements, housing bonuses and incentives; inclusionary requirements, and public programs funded locally or by the federal government. Most of the housing bonuses were oriented toward provision of middle- 
income housing. The other alternatives were basically variants on the theme.

The housing market is generally divided into low, middle and high-income segments. The draft impact statement forecast that the real estate market would provide upscale housing but also forecast "the loss of low-income residential building due to demolitions, code-enforcement closures and renovation of lowincome units to middle income units. ${ }^{8}$ Each basic alternative envisioned additional downtown low-income housing units being lost. Without public action, the Environmental Impact Statement forecast a net loss of 909 low income units, from 6,615 housing units to 5,706 units. The City's draft plan promised no loss of lowincome units. Other options varied between 5,578 and 5,717 new units by the year 2000.9 The draft EIS considered the accessory housing requirement to be most effective in providing low-income housing units compared to housing bonuses or inclusionary zoning. The accessory housing requirement could be expected to create 2,100 units compared to 220 and 430 respectively. The draft EIS proposed a potential range of measures to reduce the "unavoidable adverse impacts" of growth. These included a strong accessory housing requirement, a strengthened Housing Preservation Ordinance, and an anti-abandonment ordinance which "would restrict the length of time that a structure can remain vacant, after which the owner would be subject to a civil penalty or fine."10

The accessory housing requirement became an issue which clearly divided developers and architects from neighborhood and 
housing interests. Because each organization responded to the draft EIS, associated correspondence and testimony provides a record of each organization's position at this crucial point in time. The following list summarizes the actors and their positions:

- The Downtown Seattle Association flatly stated that an accessory housing requirement was illegal. Housing was a city-wide problem; the role of downtown was to provide regional office, service and retail employment.

- The Downtown Neighborhood Alliance and People for Downtown Housing called for an expansion of the accessory housing requirement, actually expanding protective regulations so that all persons earning less than $\$ 12,000$ would receive rehabilitated shelter.

Each group's position was consistent with its position in general on voluntary vs. mandatory housing requirements:

- The DSA believed that housing could only be encouraged and never required. A "superbonus" should be considered which would allow floor area even beyond the routine maximum floor area permitted with bonuses (20:1 FAR). The bonus should be recalculated with more favorable housing costs and market assumptions. In addition, the TDR program should be liberalized.

- People for Downtown Housing called for controls on abandonment, tougher restrictions on the demolition of low-cost housing, a more realistic housing production estimate based on TDR, and a cap on growth to one-half that allowed by the plan. 
- The Downtown Neighborhood Alliance accused the City of retreating from a previous commitment to maintain and expand lowincome housing by calling housing loss unavoidable in the EIS draft.

The effect of growth on neighborhoods, city services, housing costs were questioned by these activist organizations. Interestingly, both the League of Women Voters and Allied Arts took no stance on the issue.

\section{Mayor's Recommended Draft}

The Mayor's Recommended Draft dropped the accessory housing requirement and low-income inclusionary requirement in the face of business community opposition and the uncertain legal environment. In 1982 the Washington Supreme Court had declared that local residential subdivision exactions were illegal. ${ }^{11}$ While the case was pending, the Washington Legislature pre-empted mandatory local development impact mitigation fees. The statute allowed for voluntary agreements limited to payments for impact mitigation "reasonably necessary as a direct result of the proposed development."12 The City argued that affordable housing could only be legally provided by existing programs, bond issues and an incentive system. The housing bonus plan would link additional floor area with the construction or funding of "low and moderate income units. These were defined as households with less than 150 percent of the Seattle area median income.13 However, neighborhood and housing activists were also assured by proposed policy language of the City's commitment to maintain, if not expand, the supply of low 
income housing stock by the final EIS statement. The City sought to repair the credibility gap without using all the tools at its disposal.

With the loss of a linkage program, the City was forced to rely upon a long list of proposed actions to stabilize the Year 2000 supply of low income housing. Subsidized units would have to replace unsubsidized units which market forces would cause to be demolished, abandoned or gentrified. Figure 39A from the EIS, reproduced here as Figure 43, represents one "scenario," in which TDR provisions, floor area bonuses, housing maintenance and a revised housing preservation ordinance are added to on-going public housing programs. These programs were expected to result in maintenance of 1443 units compared to the projected gain of 2,160 units through the accessory housing program.

The LUTP envisioned that approximately 1.6 million square feet of office development rights would be gained through use of the housing bonus, primarily in the Downtown office core. Yet, by placing housing at the highest tier of floor area bonus incentives, only the largest projects would be required to provide housing. Earlier drafts did place housing in a greater priority position, but architects and developers had insisted that hillclimbs or arcades were more integral to the project and thus a greater public benefit than housing produced by the incentive system. While the floor area bonus system was expected to produce relatively few new low income units, it became an important planning controversy when Seattle-ites weighed the benefit vs. cost of projects such as the 
TABLE 39A

DOWNTOWN LOW INCOME HOUSING PROGRAM: PROPOSEO ACTION

\begin{tabular}{|c|c|c|c|}
\cline { 2 - 4 } \multicolumn{1}{c|}{} & Subsidized & Unsubsidized & Total \\
\hline 1983 SUPPLY & 3,185 & 4,126 & 7,311 \\
\hline
\end{tabular}

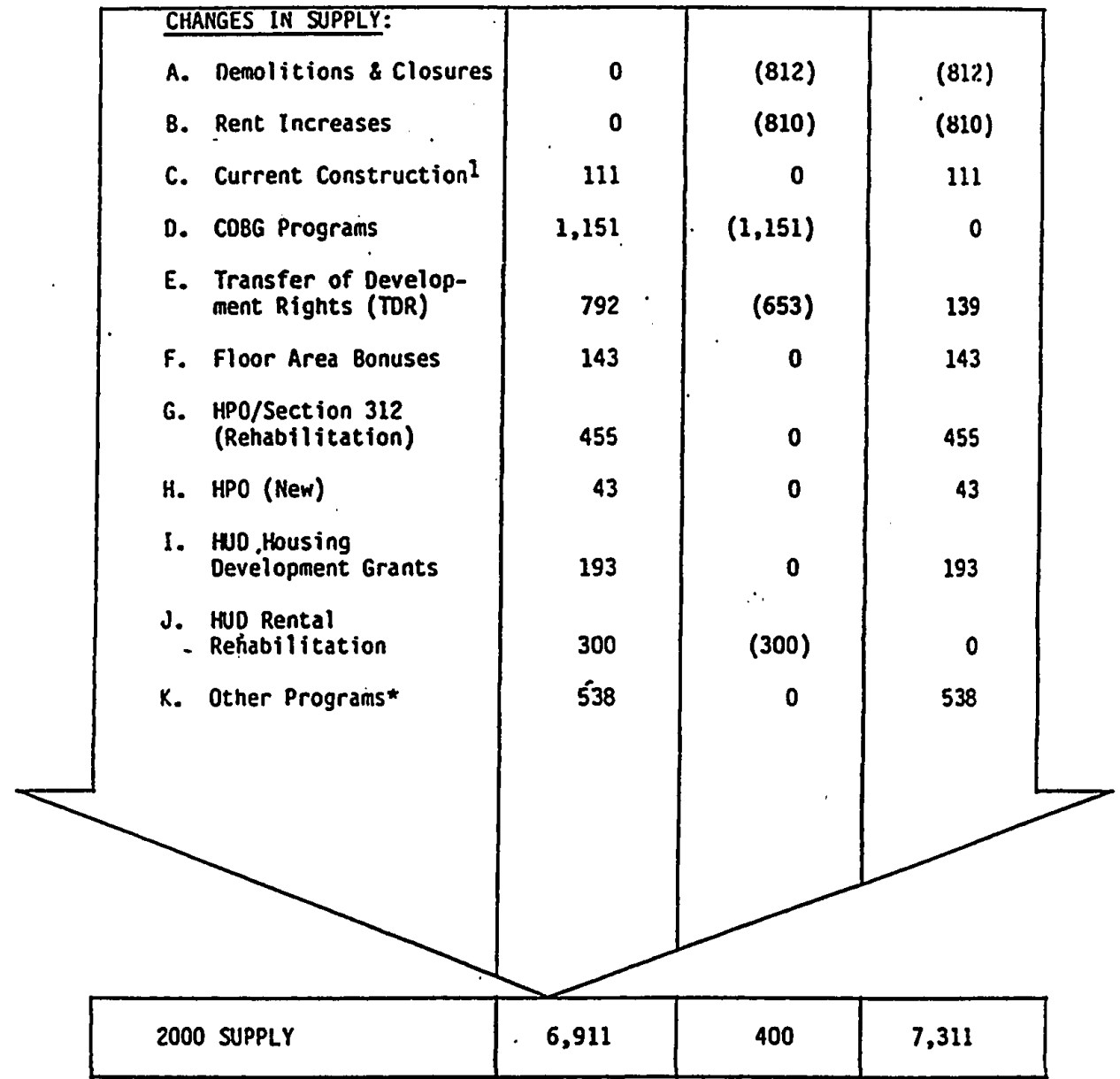

SOURCE: Departinent of Community Development, June 1984.

* Other future local, state, federal and private programs.

151 units in Market House and 60 units in South Arcade.

104

Figure 43. Downtown Low Income Program. From City of Seattle, Draft Environmental Impact Statement for the Land Use and Transportation Plan (1984). 
Washington Mutual tower (see Figures 20 and 44). In an incentive system, public vs. private benefit becomes a question of pricing.

LUTP assumed average land values of $\$ 250$ per square feet and a discount factor of 0.8 to provide an incentive to developers; typical development would generate about $\$ 20$ in housing assistance per square foot of bonused office space.

$\frac{\$ 250 \text { per square foot }}{10 \mathrm{FAR}} \times 0.8$ Discount Factor $=\$ 20$ square foot $=$ Value development rights

These numbers attempted to link land values to housing costs:

The Proposed Action would structure the housing bonus to respond to future changes in office core land values (and hence value of development rights gained through the bonus), housing production costs, and household incomes of downtown workers. Thus, as office core land prices increase due to redevelopment, a portion of the increase in value will be captured to assist the production of affordable downtown housing. Bonused housing is likely to be produced on less expensive downtown land, such as in the Denny Regrade and International District. If housing production costs increase at a slower rate than office core land prices, the number of units assisted would be greater than estimated in this analysis. Conversely, the opposite would be true if inflation in housing production costs exceed increases on office core land prices. ${ }^{14}$

\section{Court Invalidates HPO}

These estimates were conditioned upon controls over housing demolition and abandonment, i.e. the Housing Preservation Ordinance. The Housing Preservation Ordinance was considered essential to retard speculative pressure on "affordable" housing. The 1980 HPO 


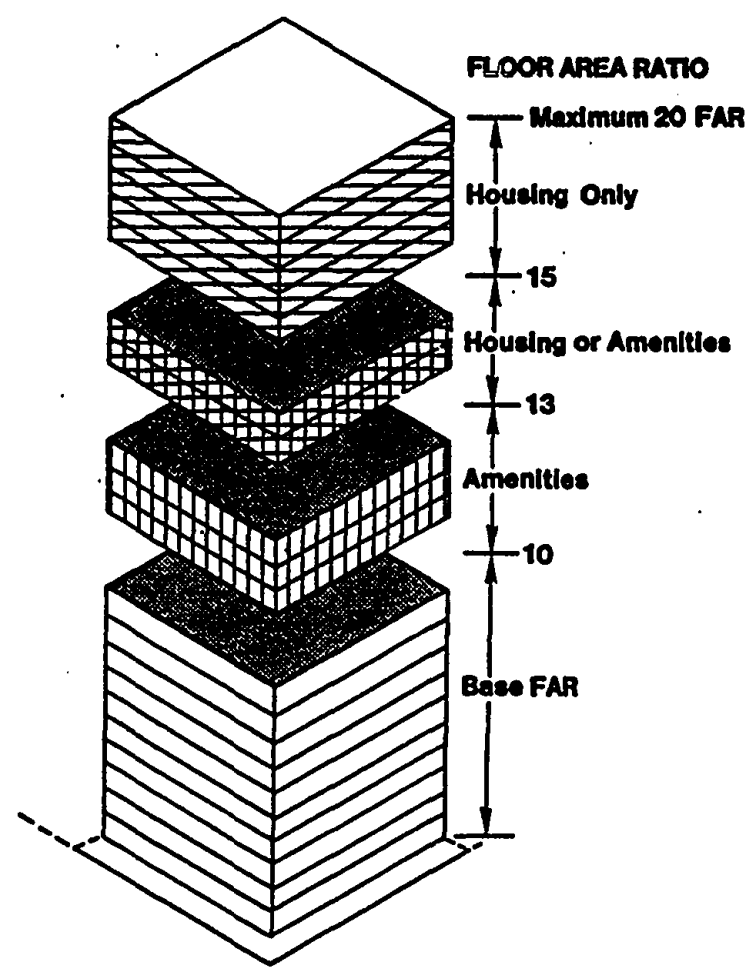

Example of Tiered FAR Schedule in Office Core 1 District

26A

Figure 44. Housing Bonus. From City of Seattle, Land Use and Transportation Plan (1985). 
was strengthened by LUTP to require that units demolished downtown would be replaced downtown, demolition license fees and relocation payments to displaced tenants were increased; lowincome housing was to be counted on a four square foot to one basis. However, the 1980 HPO was invalidated by the Washington State court in April, . 1987. The court based its decision upon 1982 legislation which prohibited real property exactions. The Court ruled that the City could not constitutionally pass on the "social costs" of housing displacement to the developers alone. The City was required to return $\$ 1.3$ million. Most of the money ( $\$ 1.1$ million) was returned to Metro which had paid the fee as part of its bus terminal project. The successful litigants, San Telmo Associates, had ties to DSA and the business community. ${ }^{15}$ Inclusionary requirements were also eased by the Mayor's Recommended Plan. The 10 percent Iriclusionary zoning requirement applied to moderate income households only. The Mayor's recommended draft dropped reference to low-income households and set moderate income levels at 150 percent of the area median income.

A more palatable regulatory device was the transfer of development rights regulation (TDR) which realized profits for owners of small residential properties. The TDR proposal allowed "unused" development rights to be transferred from low income housing to any site within an office or mixed use commercial district downtown, provided that the donor (housing) site be retained in low income housing for a period of at least 20 years. 
Although the TDR system also worked with historic structures, by assuming that the system would work on the basis of proportionate supply, about three-quarters of the transactions was expected to involve low-income housing. Both Denny Regrade and downtown owners would benefit:

Most low income housing TDR transactions will involve sending (housing) sites where land prices are relatively low, such as the Denny Regrade and International District, and receiving (commercial) sites in the two office districts where land is much more expensive. This will occur for two reasons: (1) the proposed density schedules in the office areas would only permit use of the housing bonus or low income housing TDR to achieve the highest densities, and (2) the development rights are more valuable if sold to sites in office areas.16

TDR's were considered an important part of the "incentive system." It was hoped that TDR's would account for almost onefourth of the incentive space which would be gained through TDR or bonus incentives (about 1.5 million square feet). This would provide a total of 139 low-income housing units. The largest potential supply of low-income assistance, Community Development Block Grants (CDBG), was assumed to work in conjunction with the HPO ordinance. This program would rehabilitate 1,151 units.

\section{Business Commitment}

In implicit exchange for dropping the accessory housing provision and low-income inclusionary requirements, the Mayor's Recommended plan reiterated the call for private business support

The City is seeking a commitment from the downtown business community to work aggressively and 
cooperatively in the retention of a supply of 7,311 low income downtown housing units. The business community shall agree to participate in low income housing programs through its own nonprofit housing arm, the Seattle Housing Resources Group, or other mutually agreed to mechanisms, which may include a downtown wide assessment district for public improvements. 17

This was rhetoric on the part of the City, as the plan no longer specifically asked for 500 new units from the business community. The business community had softened the original planning staff proposals to the point of rhetoric. Small property owners in the Denny Regrade were the only commercial interests adversely affected by the LUTP. Their properties were downzoned to residential use preventing speculative commercial investments. DSA lent its support to the subsequent campaign to pass a city-wide housing levy. A \$49.975 million housing levy was passed in 1985. Approximately, 1,100 units could be built with these funds.

\section{CITIZENS' ALTERNATIVE PLAN CHALLENGE}

Even as the Land Use and Transportation Plan was being adopted in June of 1985, the housing crisis intensified. The Seattle Times, Seattle Weekly, and the Post-Intelligencer published reports. The Post Intelligencer called its series, "Broken Housing, Broken Promises." Only 6,000 low income units were counted in downtown. The City administration was short 1,300 low-income units withir: a year of its commitment. The City explained that there had been a miscount of several hundred and that two hundred units had been simply upgraded and only 330 units demolished. Another $\$ 50$ million 
levy was passed to construct senior low-income housing. In 1987, it was estimated by the newspapers that there were 12,000 to 14,000 homeless people on the streets of Seattle. By 1988, the City felt compelled to impose a moratorium on the issuance of permits for demolitions or change of use of low-income housing throughout the city (Ordinance 113821, effective February 8,1988 ). Vision Seattle, a community based civic group, claimed credit for the moratorium.

Low-income housing continued to disappear despite the new policy. Seattle activists noted that the Washington Mutual Tower, the first tower to be built under the new LUTP rules and completed by November, 1988, would demolish the Savoy Apartments which contained a vacant 225 units. ${ }^{18}$ When the Council considered revising the housing bonus program to target the low-income the DSA objected.

When CAP was filed in 1989, the Council responded prior to the vote by imposing interim controls, eight years after the first request by the Seattle Displacement Coalition. The Council appointed a Downtown Plan Revisions Advisory Committee who altered the bonus system to make housing a de facto requirement and lowered FARs. Growth issues, housing displacement, and housing affordability issues had coalesced in the CAP debate.

The planners had argued that it was not possible to isolate the impacts of new office construction on the housing costs downtown and throughout Seattle. They argued that it was impossible to estimate the impact of growth: 
It is difficult to isolate the impacts of new office construction on the availability of low income housing downtown. ... There is a basic amount of downtown low income housing (between 800 and 900 units) that is in such poor condition, that if it is not demolished for new construction it will be lost through other closures, and vice versa; the overall total of low income housing loss would remain the same for all Alternatives....

It is not possible to quantify the effects of downtown employment growth on housing prices in Seattle's neighborhoods outside of downtown, due to the complex relationship between housing and employment. The generalized theory of this relationship is as follows: employment growth means growth of labor and then population growth to provide that labor. Population growth, in turn, means growth of households which, in turn, means increased demand for housing. This increased competition could mean upwards pressure on prices and rents. The amount of increase in prices and rents depends on the extent of imbalance between supply and demand and on the ability and willingness of housing consumers to pay higher prices and rents. It also depends on whether the housing market automatically responds with new development to increase the supply. Generally, employment growth would mean that housing prices are likely to be higher than they otherwise would be.

However, there are many complicating factors. For one thing, housing demand and employment levels are regional phenomena. Housing prices have increased dramatically throughout the region in recent years, and prices are likely to increase in the future even if future growth is shifted from downtown to other parts of the region.

It is difficult to isolate the effect of employment growth on housing costs, since at any one time other factors also contribute to the demand for, and the supply of, housing; employment levels, especially employment 
levels in only one section of the region (downtown Seattle) is only one factor, and probably not the most important one. Other factors affecting housing prices include changes in life style (such as increased demand for in-city living), changing demographic and household characteristics (such as smaller family sizes but greater number of households), the attractiveness of the Puget Sound region and Seattle as places to live, the attractiveness of real estate as an investment, etc. The cost and availability of money for housing construction and purchases have played a very significant role in setting housing price levels in recent years. Financing has been available only at very high interest rates, due to the inability of savings and loan institutions to attract inexpensive deposits in competition with alternative saving vehicles. 19

Yet, housing activists charged City complicity in "bulldozing the poor." John Fox, the most prominent activist, wrote that Seattle had traded off its soul for a glitzy downtown:

There is much talk about the liveability of Seattle for the middle class and families. Yet the city is losing its middle class as more families join an "underclass" of long-time residents-minorities, elderly and the poor. They coexist with a growing class of young professionals who are the recipients of the jobs created by the highrise explosion. Nowhere are the contrasts as visible as they are on downtown streets, where 'yuppies' uncomfortably rub shoulders with an army of unemployed and homeless street people.

Downtown growth, however, is not merely a product of changing market conditions. There are conscious decisions made by locally elected officials which promote the office boom at the expense of other economic options for Seattle. The city, Metro, the State of Washington and the federal government will spend over one billion dollars in the next three or four years to accommodate more office growth downtown. They will provide added transit capacity (the downtown bus 
tunnel), a convention center, a new Westlake park, an art museum, and numerous street improvements for the area. More city services -sewer, water, electric wiring, police, fire - are also earmarked for downtown.

While the city allocates a large chunk of its budget each year to support the office boom, it spends little to minimize the effects of that growth on downtown's longtime residents. Only about four million dollars will be available city wide this year for low-income housing production. Most of these funds come from federal sources that are drying up. It costs more than $\$ 50,000$ to rehab or construct a new single unit of low-income housing. Roughly $\$ 20,000$ of that is borne by the city, using federal funds. The rest of the funding comes from non-profit housing organizations -foundations, churchesor private developers meeting what replacement requirements do exist. During the coming year, city programs will be lucky to add 400 units to the lowincome stock. In downtown alone, developers already have applied for permits to demolish 700 low-rent units in 1986.20

Vision Seattle and Citizens for an Alternative Plan also disagreed with the City's neutral conclusion. The CAP resolution directly ties liberal permitted floor areas and amenity-oriented bonuses to displacement of the poor and an affordability crisis for the middle-class:

WHEREAS, thousands of units of downtown low-income housing have been lost in recent years to office development, with thousands of additional units in danger of demolition; and

WHEREAS, the city-subsidized replacement of downtown low-income housing lost solely because of office development will cost taxpayers millions of dollars, which could better be spent for other purposes if such housing were preserved; and 
WHEREAS, overdevelopment of downtown office space will adversely affect the city's residential neighborhoods, driving up the price of homes, depriving middle income families of the option of living in Seattle, and increasing the likelihood of residential up-zones in single family areas 21

CAP put restrictions on growth and put low-income housing much farther down the bonus tier. Floor area ratios were reduced to $7: 1$ and less without provision of housing. To build a moderatelysized building a developer must now support housing.

\section{CONCLUSION}

The continued loss of housing throughout the study period presented two very different challenges to housing activists and the downtown business community. Housing activists, themselves negatively affected by the ever worsening housing market, saw this issue as crucial to Seattle's quality of life at the least and a matter of survival at the extreme. These activists, with the help of Commissioner Hildt, pushed thorough a housing preservation ordinance although they failed to pass rent control. The downtown business community accepted housing displacement as the price of re-investment in the core. The Downtown Seattle Development Association organized an ineffectual promotional campaign to attract middle-class residents as its first response to the crisis. The DSDA fought both rent control and the housing preservation ordinance. DSDA supported a housing bond issue as an alternative to rent control and the DSDA fought the HPO in the name of the small real estate owner. Although business owners were eventually able 
to have the courts rescind the HPO, its temporary survival thanks to Hildt and Royer22 signaled that the urban regime split between downtown business interests and progressive City Council politicians.. The urban regime was unable to agree that economic development imperatives superseded all public regulation of private housing investment decisions. (Figure 45 illustrates splits in the urban regime at the beginning of this case study period.)

The Land Use and Transportation Plan allowed activists to turn to other progressive tools such as accessory and inclusionary housing requirements, linkage and city housing programs. These proposals were supported initially by the Royer administration and were proposed in the first plan draft. DSDA opposition shifted the emphasis back to government funded and taxpayer supported programs. LUTP planners retreated to a defensive position; the Draft and Final Environmental Impact Statements decoupled continuous downtown growth and continued housing displacement. The EIS was forced to posit an unlikely scenario in which 7,311 low-income housing units would be saved by hypothetical use of housing bonuses. The relatively low influence of the housing activists is illustrated by the last place assigned to housing in the original bonus system. As the Land Use and Transportation Plan got closer to Council passage, incentives for provision of housing were lessened, requirements became encouragement and business was asked only for promises. The business community did support both bond issues, but these funds were levied on a city-wide basis and administered by the DSDA's own housing development arm. The urban regime 


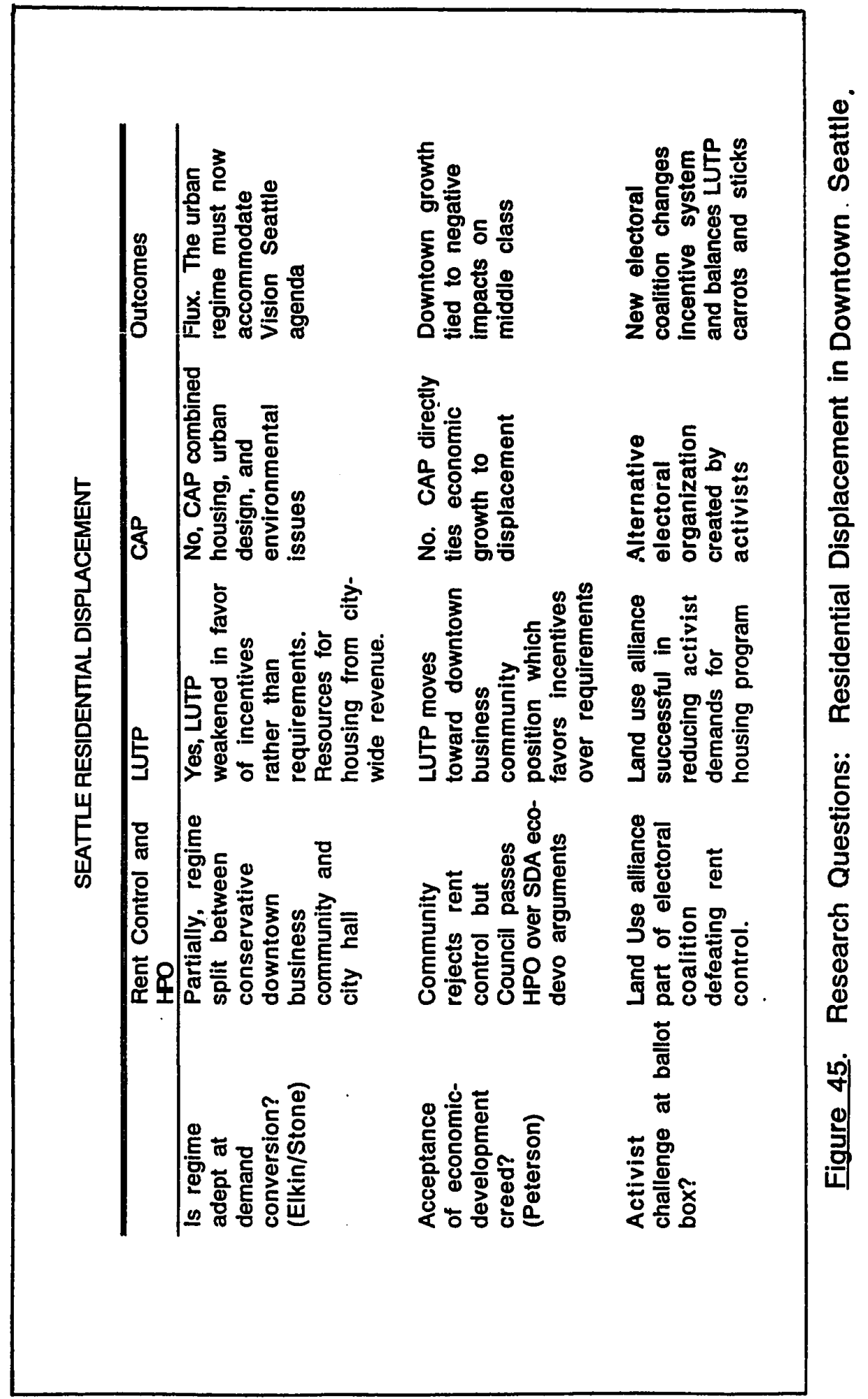


followed its disposition to accept the business community's preference for city-wide funding. (As if Portland were to extend its tax increment financing boundary to the entire city and privatize PDC.)

The urban regime effectively ignored the housing crisis as it worsened. By 1988 , activists estimated that 12,000 to 14,000 homeless were on the streets of Seattle. The Seattle Displacement Coalition had tied housing losses to downtown growth as early as 1979. The City was open to criticism that it subsidized downtown development at the expense of downtown low-income housing and the city's residential neighborhoods. The activists equated this favoritism to depriving middle income families of the option of living in Seattle and increasing the likelihood of rezoning single family neighborhoods to apartment zones. The Citizens' Alternative Plan referendum confronted the urban regime with the powerful neighborhood fears of middle-class displacement.23 CAP combined housing, urban design and environmental issues - a combination of demands beyond the urban regime's ability to control. This was an unmanageable political factor. The disposition of the courts and the legislature had worked in favor of DSDA/DSA positions, but the activists had shifted the debate from property rights and the limited dialogue of the downtown urban regime to a city-wide issue. This challenged LUTP's position that growth could be harnessed to neutralize the negative impacts of growth.

These unresolved conflicts over housing policy reflect the differing political styles in Portland and Seattle. Portland came to 
a compromise and then reduced the strength of the activists through the redefinition of the problem from North Burnside to North Downtown. The total acceptance of redevelopment outside the Skidmore/Old Town historic district and resultant displacement was only tempered by the inability of the regime to ship the transients elsewhere. Large business owners dominated redevelopment policy. In Seattle, the city-wide impact of the housing crisis brought citywide attention to this issue. The failure of LUTP to manage the issue and the absence of an effective public response undercut the public's willingness to allow a private-oriented approach which left the issue to the good works of SHRUG. The urban regime must now accommodate an alternative agenda. This activist agenda may rebalance the trade-off between growth and housing supply. 


\section{ENDNOTES}

1 John V. Fox, "Bulldozing the poor away - Seattle traded off its soul for a glitzy downtown," Counterpoint, January 13, 1986.

2Jane Hadley, Seattle Post-Intelligencer, SDC Squad Works Like a Regiment

${ }^{3}$ City of Seattle, Department of Community Development, Housing_Report (Seattle, 1979), summary.

${ }^{4}$ Fremont Public Association, SCOPI report/housing, (Seattle, 1979), summary.

${ }^{5}$ City of Seattle, Office of Pollicy and Evaluation, Background Report of the Land Use and Transportation Project, March, 1981, pp. 5-7,

${ }^{6}$ City of Seattle, Land Use and Transportation Project Draft Land Use and Transportation Plan for Downtown Seattle, June, 1983, pp. 45-46.

${ }^{7}$ Seattle Weekly, May 22, 1989 and Seattle Post-Intelligencer, March 27, 1985.

${ }^{8}$ Land Use and Transportation Plan, Draft Environmental Impact Statement, October, 1983, p. 44.

${ }^{9}$ City of Seattle, Land Use and Transportation Project, Draft Environmental Impact Statement. Forecast Year 2000 Downtown Housing By Type, October, 1983, p. 197.

${ }^{10}$ City of Seattle, Land Use and Transportation Project, Draft Environmental Impact Statement, October, 1983, p. 45.

${ }^{11}$ The citation is Hills Homes, Inc. v. Snohomish County, $97 \mathrm{Wn}$. 2d 804,65 Pacific 2d 193.

${ }^{12}$ The citation is Washington revised Code 82.02 .020 (1983).

13 In 1984, $150 \%$ of the Seattle area median income was $\$ 34,000$ for a one-person household and $\$ 38,900$ for a two-person household. Thus housing considered affordable to those making between $\$ 51,000$ and $\$ 58,350$ qualified for a bonus! The Mayor's Recommended policy clearly focused on the middle-income market, defined as $150 \%$ of median income: "Development of a strong middle income community is critical to the overall health of downtown and is key to mitigating many of the impacts of employment growth. To create downtown middle income communities will require aggressive actions by both the public and private sectors. Major office development must assist affordable housing production. The City must take action to reduce housing production costs and target existing programs to assist middle income housing production. In addition, changes are needed in State laws which now preclude City use of property tax district (Community Redevelopment Financing) powers of condemnation and public subsidies to facilitate private or public development of moderate income housing. City of Seattle, Land Use and Transportation Project. Mayor's Recommended Land Use and Transportation Plan for Downtown Seattle, May, 1984, p. 61. 
${ }^{14}$ City of Seattle, Land Use and Transportation Project, Final Environmental Impact Statement, August, 1984, p. 109.

${ }^{15}$ Seattle Weekly, "Developers Slip a Bill," unknown date.

${ }^{16}$ EEIS, p. 107

17 Mayor's Recommended LUTP, Guideline 8: Downtown Business Commitment May, 1984, p. 60.

18peter Staten, "Seattle's New Landmark: The Tower That Dares to Be Fun," Seattle Weekly, November, 1988, November 16, 1988.

$19_{\text {FEIS, p. } 115}$

20 John V. Fox, "Bulldozing the poor away Seattle traded off its soul for a glitzy downtown," Counterpoint. January 13, 1986.

${ }^{21}$ CAP initiative.

22The reader may have noticed that Royer plays a different role in regard to housing displacement compared to his push of the Rouse Westlake Mall. It may simply be that as Mayor Royer was dedicated to getting projects done. The Clty had enormous sunken costs in both money and pyschological capital invested in the Rouse project.

${ }^{23}$ Peter Steinbrueck, Pat Stroshal and Ted Inkeley set out the Vision Seattle view in three articles in the City Watch newsletter, The Forum. These articles are "Public Costs and Private Benefits, A Closer Look at the New Washington Mutual Tower," by Peter Steinbrueck, Vice-President of Vision Seattle, March, 1989; "Housing, Growth and the CAP Debate, by Pat Strosahl, President of Vision Seattle, May, 1989; and "Downtown Boom, Neighborhood Fallout," by Ted Inkley; Vision Seattle Advisory Council, no date. The Vision Seattle Issue Agenda is "A working statement of the beliefs and ideals of the combined Vision Seattle membership and Board of Directors," September 16, 1990. 


\section{CHAPTER IX}

\section{CONTRASTS IN URBAN REGIMES}

\section{HOW THE URBAN REGIMES OPERATE}

\section{Portland}

In Portland, the business association, private consultants and public bureaucracies are indistinguishable. Representatives of banks, utilities, large property owners and large property-owning corporations serve on the boards of commissions such as PDC on an on-going basis or an ad hoc basis on projects such as Portland's Future Focus. (The Future Focus strategic plan effort acknowledged them as "stakeholders.")

The Terry Schrunk/Bill Roberts days have passed, but the Portland Development Commission and Association for Portland Progress are adept players. The same small group of private consultants are useful to PDC and larger business interests, project after project, issue after issue. Furthermore, westside downtown interests are quickly coming to terms with new players such as Pacific Development, Inc. on the eastside. The ease with which the Planning Bureau put together a "Blue Ribbon" committee to ratify the Central City development review process - the "Central City Fundamental Guidelines" - indicates that the local influentials such as downtown property owners Bill Naito or Melvin Mark, utility executive William Scott in Lloyd District, and entrepreneur Jack 
Burns on the eastside are well known and accommodated. These are all legitimate members of the growth machine or entrepreneurial regime. ${ }^{1}$

A potential rupture in this remarkable consensus among the growth coalition over Cadillac-Fairview was averted when a new system of private business participation in PDC projects was institutionalized for Rouse. A new request for proposal system allowed local firms full warning of PDC initiatives.

With the completion of the Central City Plan and the adoption of two urban renewal districts on the eastside, especially around the Convention Center, little downtown land lies outside PDC's domain. ${ }^{2}$ Westside/eastside conflict has been replaced by debates over core vs. suburban development restraints such as regional parking limitations or expansion of the urban growth boundary which restricts speculative development on farm land. The potentially disruptive Central City Plan issue - unequal parking restrictions on west and east sides - is now being quietly decided. A policy committee consisting of City Council members and Association for Portland Progress representatives will pass on previous work by a citizen's committee and bureaucratic technical committee.

Presently, the City Council expects development disputes to be resolved internally without City Council debate, much less a role for citizen ballot initiatives. Crime and city/suburban disputes displace Downtown Portland issues. All city council candidates support downtown growth, presented as a pro-environmental policy to avoid regional sprawl. An entrepreneurial urban regime is united 
in pursuit of a common "politics of profit." 3 Yet, little of this seems forced. The 1980's represented the institutionalization of city involvement in private development decisions and an easy involvement of influentials in city politics. The city plans on the basis of influentials who seek government involvement in a relatively weak economic climate. A vision, such as returning the east bank of the river to Portlanders, in the spirit of Tom McCall, can animate an activist group such as Riverfront for People but only for a short time. Most citizen involvement is eventually managed in carefully tailored committees. This mechanism works against individual influentials as well. Not all the demands of individual members of the regime were met. For example, the City Council turned down most demands for individual floor area increases in the Central City Plan. Council members can usually check with the Association for Portland Progress to differentiate an individual interest from general business concerns.

Portland elections have not challenged CBD growth as in Seattle since the 1950s. Successful local businessmen are integrated into Portland decision-making regardless of the administration (unlike the abrupt transition in Seattle from Royer to Rice) Portland even has an unofficial mayor, Bill Naito. Elkin's criticisms of Dahl's pluralism seem reasonable in Portland. Portland is a place where the "institutional context" promotes an entrepreneurial regime. Elkin's description of an entrepreneurial regime politics in Dallas fits Portland just as well: 
The essential point of difference between this sort of political economy and the pluralist and federalist types is that the behavior of public officials in the entrepreneurial version is not as much shaped by the building of electoral organizations and political coalitions. Concomitantly, public officials are less drawn to land-use schemes to generate the stream of benefits helpful to their electoral careers. Rather, they are drawn to land-use schemes because the political arrangements work to recruit those with a strong disposition to ally themselves with local businessmen...Equally, important, in entrepreneurial political economies, insofar as citizens play an active role in political life, they are drawn into politics either to speak for their neighborhood, ethnic group or some other interest or as a bureaucratic client. ${ }^{4}$

\section{Seattle}

Elkin's description does not fit Seattle well. In Seattle, the growth coalition split badly over Westlake Mall; local papers even supported CAP. The local land use alliance was weakened by CAP. The retailers could not even keep Pine Street open. The CAP committee has turned into a de facto design commission despite business (and their architects') opposition. Vision Seattle's electoral challenge has put Margaret Pageler on the Council.

Early victories by downtown business interests such as repositioning Westlake Park into a shopping mall, monopolizing discussion of LUTP regulations and bonuses, and shifting the cost of a housing program to a general bond issue are increasingly offset by a distrustful electorate. A general distrust of government involvement in private affairs prohibited the use of eminent domain in the Westlake process. And local environmental politics created a 
requirement for an environmental impact statement and continues a complex and antagonistic development review process. The establishment entrepreneurial regime is in a trough. The functional bureaucracy is fractured in Seattle. Numerous reorganizations and lack of contact among planners has left a void. Most notably, the lack of eminent domain power and tax increment financing leaves the city with few carrots or sticks. The floor area bonuses scaled down by CAP were some of the few carrots available to shape downtown development

Seattle lacks the links between land use alliance, bureaucracy and electorate that Portland enjoyed. For example, when Strachan's outsider, citizen-driven process Central City Plan faltered, PDC provided the requisite market perspective. The Planning and Transportation Bureaus were able to translate the desire for eastside downtown expansion into appropriate zoning and capital improvements needed to push the expansion. In Seattle, the planners successfully negotiated a compromise acceptable to the more civicminded downtown interests but disregarded neighborhood-oriented activists to the city's peril.

Social policy, as debated in the downtown plans or individual initiatives, reflects the differing regime structures in both cities. In Portland, Burnside Community Council stood as the only institution outside the regime consensus on "tough love." Only Baloney Joe's, run by the BCC, would provide homeless shelters without regard to impact on neighboring property values. The close links among the other social service providers, local governments 
and other funding sources led to the Clark-Shiels truce between social service providers and influential property owners. BCC went out of operation and North of Burnside became North Downtown incorporated into the arc from downtown to Lloyd Center. In return, PDC was pressured to begin low-income projects throughout the Central City (Downtown Housing Preservation Program). The weakness of the housing activists was signaled by the failure of their proposal to reconfigure PDC into a housing development agency.

In Seattle, the fight over rent control, the housing preservation ordinance and proposed LUTP linkage requirements revealed a clear divide between the downtown business interests and housing activists allied with the Greater Church Council of Seattle. The formation of a privately funded counterpart to PDC's Downtown Housing Preservation Program did not result in diminished antagonism. Issues such as housing displacement have resulted in city policies like the housing preservation ordinance, which have led to numerous court battles and stalemate.

Both cities completed their Rouse projects. Portland successfully negotiated conflict; Seattle survived conflict. The ability of PDC to reform the process - selection, negotiation and financing through the RFQ and RFP process - allowed Bill Roberts, chair of the Commission, to quietly direct its retail mission. The Rouse Company renegotiations were never subject to significant community oversight, much less challenge. The bumpy Seattle process led to the creation of another political grouping, Victor Steinbrueck's Citizens Against Westlake (C.A.W.). Compromise was 
not satisfactory to later activists and Public for an Open Westlake's frustration led to Vision Seattle.

During this study period, Portland and Seattle have pursued remarkably similar CBD redevelopment policies. Both cities proposed massive redevelopment schemes to modernize their cores after the war. Modernization included new permissive zoning codes, proposed demolition of historic districts and promoted new freeway access. From the 1970 s on, both cities recognized the negative impact of these proposals. Both cities talked about quality of life and urban design quality. Both cities committed to retaining downtown housing. Both cities even employed Rouse projects which are located in similar strategic locations in order to anchor an upscale retail core. Yet the politics of urban redevelopment have differed in significant ways. In Portland, a downtown plan was adopted in response to a visibly declining downtown. Implementation was slowly developed over the course of a decade through urban renewal, capital improvements, zoning and design review. Seattle responded to neighborhood concerns over the quality of life with a policy plan, Goals for Seattle 2000 which papered over real conflicts within the community.

While both Portland and Seattle shared the vision of a regional office and commercial core leavened with pedestrian amenities, different histories separated Portland's success and Seattle's partial failure. In Portland, Downtown Plan participants began a decade and a half process leading to mutual accommodation as reflected in the Central City Plan. Neighborhoods such as Northwest 
which was adjacent to downtown, and Irvington, just across the river, were key players in writing the Downtown Plan. These neighborhoods were anxious that downtown be revitalized as the cornerstone of Portland livability. Downtown was surrounded by the freeway, Skid Road, and eastside industrial uses from the neighborhoods. It would be many years before Downtown would create displacement pressure. Portland institutions were strengthened. The Portland Development Commission was redirected away from the urban clearance projects of the 1960s. New projects promoted downtown growth but with a sophisticated blend of new construction and rehabilitation. PDC no longer acquired vast tracts of blighted neighborhoods, but specific sites to further specific goals of the Downtown Plan as amended by the Central City Plan. These project decisions were ratified by amendments to the appropriate urban renewal plan which were reviewed by the Development Commission, Planning Commission and City Council in advance of condemnation. These amendments specified the public purpose and requirements of developers. The Planning and Transportation Bureaus worked in tandem with the Development Commission

In Seattle, the adoption of the Seattle 2000 Commission's Goals 2000 led to a city-wide effort to rewrite the Comprehensive Plan, a process in which the city lost credibility with the neighborhoods. The city liberalized the single-family zoning code only to experience overly large and incompatible residential development. Maximum allowed density was then scaled back in a 
decade-long period of neighborhood/City Hall acrimony. Ultimately, Seattle activists focused on the downtown office core as the source of increased pressures on the neighborhoods. The Citizen's Alternative Plan tied downtown development politics to powerful neighborhood politics. Lacking a powerful development commission, the Seattle government emphasized the regulatory aspect of planning and adopted a local environmental impact assessment process. This regulatory process created visible winners and losers. The impact statement provided information for opponents of particular projects; for example, the CAP initiative depended for its electoral propaganda upon the Washington Mutual office tower environmental impact statement

By the late 1980s Portland and Seattle had traveled in opposite directions. Portland's neighborhoods supported downtown redevelopment guided by the "public-private partnership." Seattle's downtown entrepreneurial regime was challenged by neighborhood, social service and church-based community groups.

\section{WHY THE PORTLAND URBAN REGIME IS MORE SUCCESSFUL}

Returning to indirect as well as direct determinants of public policy, we can answer why Portland has generated a more successful urban regime than Seattle. Some of these reasons have been detailed by this research; some are more speculative.

The period of greatest downtown construction benefited Portland more than Seattle. Most of Portland's construction growth came after the adoption of the Downtown Plan and tax increment 
financing in the early 1970s. Portland's parking and retail core

crisis lent legitimacy to efforts to stimulate growth. The Downtown Plan was a corrective to concerns raised in the 1960s about quality of life issues and was well-positioned to meld quality of life issues and economic development through creation of a "public-private" partnership. By 1982, the same "links" had been in place for a decade. In Seattle, downtown growth peaked just as the Land Use and Transportation Plan was adopted. There was no time for adjustments. Seattle growth seemed to be destroying whole precincts (such as Pioneer Square and Pike Place Market). Also, unlike Portland, Seattle experienced cycles of boom and bust which further reduced confidence in the worth of Seattle's official assumptions about future downtown growth, production of housing or shape of the built environment. Planning in an uncertain economic environment is more difficult than in a steady environment like Portland's. As a result, policy issues came to be understood differently in Portland than in Seattle. While Portland sought to halt downtown decline, Seattle's Land Use and Transportation Plan sought to redirect growth. Portland could spend public funds for its open space but needed private investment to revitalize the retail core. Seattle had budgeted for a public open space but seemed unable to agree on the mix between public and private space. Both cities sought to halt the "natural" workings of the real estate market. While Portland struggled with the depressed market of skid road and frustration in redeveloping the area north of Burnside, 
Seattle sought to halt displacement caused the rising demand and rising rents.

The impact of previous downtown plans, projects and policies favored the Portland urban regime. The Portland Downtown Plan proved that mass transit was the solution to access problems of the constricted downtown, rather than more and more shopper and employee parking. This solution put government in a permanent activist role. Furthermore, adoption of a parking lid and design standards and discretionary design review brought local government into every development and redevelopment decision. Siphoning off property taxes directly to PDC through the tax increment revenue system balanced regulatory sticks with public subsidy carrots. In contrast, Seattle's legendary World's Fair and Forward Thrust bond issues were private successes. These projects originated within the business community, making legends of Hotelman Eddie Carlson and Ford dealer Joe Gandy and attorney Jim Ellis. 5 With permissive zoning in place, with no design standards or design review and no height requirements, Seattle developers could think big. Every downtown office core block could be envisioned as a site for a world-class skyscraper. Larger projects meant that more was at stake with each decision. Larger projects also created bigger impacts. Seattle's environmental impact statement process was indicative of a stronger regulatory climate.

The interplay of private investment climate and governmental response results in a contrast between process and product orientation. Portland is process-oriented. Seattle is product- 
oriented. Process-orientation means frequent communication between property interests and City Hall. Consultants grease the flow of communication. Product orientation in Seattle means that developers are more leery of the exercise of bureaucratic discretion. Design review was successfully resisted until passage of CAP.

Portland benefits from a closer tie between elite residents and the downtown core. Both cities are middle-class cities without vast areas of inner-city slums surrounding the center. Both cities retain close-in wealthy residential enclaves - Portland's West Hills and Seattle's Queen Anne Hill - which literally look across the CBD to Mount Hood and Mount Rainier respectively. Portland particularly benefits from a close relationship in which residential neighborhoods are cut off from their views if downtown towers rise above $\mathbf{3 5 0}$ feet in elevation. Elites attend downtown religious and cultural activities during the weekend as well as working downtown. This physical and functional proximity has created a greater interest in downtown among Portland's west side elite. Seattle's connection is somewhat more distant; Queen Anne Hill is at a greater distance from downtown and religious institutions are spread throughout the city. Until the recent move of the Seattle Art Museum to downtown (not to Westlake), no high culture institutions were located downtown. Seattle's elite is spread throughout north Seattle and the suburbs to the east of Lake Washington. This elite is also less intimately involved with downtown development interests. Much of Seattle's prosperous middle-class is tied to Boeing, the University of Washington, and the electronics industry, all of which 
are all located outside downtown. At the same time, this independent base has allowed sophisticated residents to form coalitions in opposition to the downtown urban regime. CHECC represents an early, business-oriented grouping. Vision Seattle currently represents a coalition of north Seattle activists.

Seattle's downtown business association has fought defensive battles. Since CHECC, Seattle City Council and the Seattle downtown business association have fought defensive battles against rent control, against the Housing Preservation Ordinance, against Royer's early LUTP housing linkage proposals, and then against the Citizens' Alternative Plan. Also, crime and the state of the schools have replaced planning for downtown growth as the significant issues for post-Royer Seattle. In contrast, the Association for Portland Progress has been able to act strategically, providing planning services that the City has ceded to the Association - most notably, a strategic plan for the downtown completed after the adoption of the comprehensive Central City Plan. APP is currently teaming up with PDC and downtown property owners to abolish the downtown parking lid.

Portland's Commission form of government is less transparent than Seattle's Strong Mayor-Strong Council form of government. Both cities have adopted non-partisan, at-large political elections which makes the threshold for activist activity much higher. In addition, however, Portland's Commission form of government works to the activists' disadvantage. The Commission form of city government is ostensibly weaker. The Mayor has but one vote of five 
and the Mayor shares administrative duties with four

Commissioners. But this system creates the policy equivalent of the old ward system. Downtown development politics generally concerns only the Development Commission, the Planning Bureau and the Office of Transportation. The Mayor typically oversees the Development Commission and assigns the Planning and Transportation Bureaus to one or two Commissioners who is/are keen to further downtown growth. Only three votes are required at Council to pass pro-growth policies. Even if an activist were to win election to Council, that one vote would not make a difference. The reader may recall the difficulty when Commissioner Strachan attempted to balance citizen representation with the usual progrowth agenda. In Seattle, an independent, strong Council form of government means that there are potential places at City Hall for activists. Seattle activists have advanced to the Council.6 Portland's successes mask the trade-off between effectiveness and democracy. The successful Downtown Plan implementation made it easy for Portlanders to feel that things were going well downtown. Few failures have meant less controversy. In Seattle, the failure to get projects like Westlake going left more time for new activists to follow-up where Victor Steinbrueck left off.

Systemic power arrangements in both cities favor those who value the use of space for exchange purposes versus those who value space for use purposes. The former faction, the "growth machine" coalition, tends to benefit from systemic power. The latter faction 
often must justify the stability of a community as financially rewarding. Historic preservationists have fallen for the trap of "adaptive reuse." They cannot fight for preservation of an historic structure if a convenient reuse of the structure is not apparent. Activists must highlight the biased nature of the downtown development process. An entrepreneurial urban regime creates institutional arrangements. These institutional arrangements are buttressed by the sociological process of systemic power or stratification. Stone writes that the "durable features of the socioeconomic system" confer advantages and disadvantages. Portland case studies show an increasingly durable system. Steady growth, public investment according to a plan, and the longestablished ties between City Hall and the downtown community have created a predictable investment climate. Both City Hall and the business community increasingly institutionalized development review. The business community accepted design review, aware that approvals would be forthcoming with only minor aesthetic modifications required by the City. PDC would control public investment and the board of PDC would be almost synonymous with the leaders of the business community. APP proved a model of the new, sophisticated downtown business association. Portland is an extremely cautious town. Tax increment funding insures that proposed projects are carefully reviewed to avoid the risk that project revenue cannot pay off bonds.

In Seattle, the socioeconomic climate was challenged as the middle class found itself disturbed by the boom of the 1980s which 
created a real housing crisis. City Hall and the downtown business community refused to acknowledge the city-wide impact and citywide interest in downtown development. The activists' articulated demands, so clearly indicated by each set of responses to the LUTP or Westlake draft Environmental Impact Statement, met an official disposition to consider neighborhood interests as peripheral to City Hall/downtown business community negotiations. Seattle pursued the same pro-growth policies as Portland but the pluralist composition of Seattle caused an increasing backlog of unmet demands.

Where Portland and Seattle differed most greatly was the composition and strength of dissidents. In the three case studies we have examined, there have been few Portland ad hoc citizen committees, and no political groupings. Ed Tenny and Michael Stoops were isolated figures. Save Our Livable Downtown quickly vanished. Even when the alternative was another pro-growth strategy such as the crescent approach advocated by George Crandall, the alternative vision was not allowed to compete with the urban regime's preference. The Seattle urban regime has had to confront enduring organizations - Allied Arts on urban design issues; SDC/Greater Council of Churches on housing issues; environmentalists; and finally, Vision Seattle, an organization capable of getting a candidate onto City Council.

One may compare the CAP referendum to the ultimate prodevelopment disposition of the Central City Plan. The public demand for a true river city became policy number one, but mostly as a 
graphic. PDC created policy rather than implement the CSC's vision. Stone's stratification theory provides a plausible reason why the Portland agenda excludes viable alternatives to official policy. Plans and projects simply represent the articulated demands of local Portland influentials who came to consensus as the result of the Downtown Plan crisis.

\section{SUMMARY: LESSONS FROM SEATTLE AND PORTLAND}

I hope that this dissertation has shown that Portland and Seattle have remarkably similar socio-economic environments. Similarities are greater than differences. Both downtowns experienced growth and both cities created plans based upon a similar desire for continued regional dominance and a new concern for quality of life issues. Both cities desired a thriving retail core and both cities recognized that old housing stock was disappearing. Both cities used plans and projects to address these issues. Each city brought mostly middle-class interest groups to the table, but favored business interests.

Seattle distinguished itself with the dogged commitment and perseverance of ad hoc electoral coalitions. In Portland, government officials and associates in the downtown business community proved to have the greatest staying power. In both cities the effectiveness of demands for resources were affected by the status of the parties involved. Business interests could hire consultants to present material at public meetings and could mobilize informal support. Portland brokered a Central City Plan which accepted 
eastside interests into the core but restricted the role of housing activists and architects who threatened the success of the crescent concept. The Central City Plan provided the means through which the entrepreneurial regime has consolidated the economic objectives of the Downtown Plan and reached across the river to meet the regional challenges of the next century. Downtown interests and surrounding neighborhoods have come to terms. No outside activists threaten. In fact, environmentalists accept the argument that the center must grow to avoid peripheral sprawl. The definition of downtown is successfully enlarged and within the boundary, development can proceed without much review of impacts (see Figure 46). Housing activists are closely managed. Shiels and Obletz is currently engaged in a process to reduce the number of shelter beds and close the homeless shelter on the east end of the Burnside Bridge. Portland also obtained the Rouse project by re-adjusting PDC's procedures to provide a place at the table for local investors.

Seattle wrote the Land Use and Transportation Plan which brought business owners closer to accepting liberal notions of quality urban environments. But the city hall and downtown business parties to these agreements neglected to understand the increasing impatience of neighborhood and social activists who came to see downtown growth as the root cause of housing price inflation, housing displacement and the deteriorating quality of life. Westlake Mall was built without responding to Seattle-ites love of the outdoors and long-stated policy of providing a real park in the 


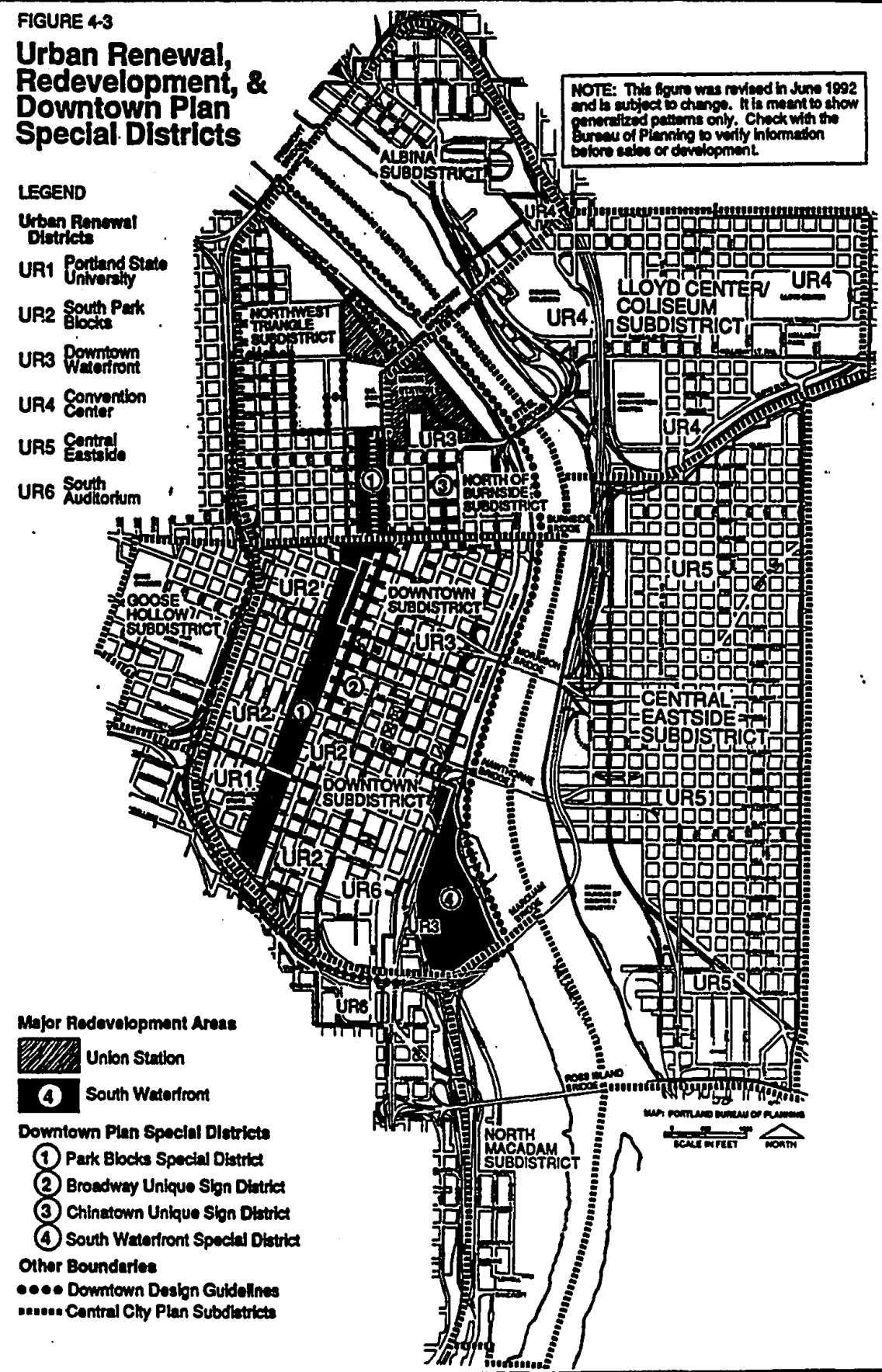

Figure 46. Portland: Urban Renewal, Redevelopment and Downtown Plan Special Districts. From City of Portland, Developer's Handbook (1992). 
heart of Seattle. The urban regime's disregard for activist concerns over the proliferation of towers and loss of housing fueled CAP.

Although these case studies are not exactly comparable, they provide a convenient pause to this study. Elites in Portland have successfully pursued a strategy to maintain downtown's preeminence, adapting to the dispersion of the population throughout the region. Portland has always been portrayed as conservative in nature. But this conservatism has masked a very successful publicprivate partnership.

In Seattle, the urban regime is under attack. Ad hoc citizen groups have risen in the past and again threaten city hall/downtown business interests. The passage of CAP and continued efforts by Vision Seattle are part of a continuing, cyclical contest between downtown interests and middle-class neighborhood residents. This is a surprising conclusion because the "Seattle spirit," a legendary entrepreneurial attitude, seems to promote unbridled growth. Despite the World's Fair booster image of Seattle spirit, there has always been a strong progressive element in the electorate. Royer was elected on a progressive platform, attacking the Westlake Mall project. The public voted for CAP. The downtown agenda was eclipsed with the election of Norm Rice and the elevation of public safety and education concerns.

Pro-development policies do not always mean clear positive economic benefits, as suggested by Peterson. Lack of conflict is not equivalent to consensus. Lack of conflict in Portland means that there are relatively few dissidents. Their resources are scant and 
the urban regime manages the few demands which surface. More conflict in Seattle meant a less durable outside environment and more powerful and able citizens. This is not to say that conflict is better than consensus, but that the real costs and benefits of downtown growth are clearer to a citizen of Seattle.

These case histories describe a city in which the urban regime, meaning the downtown business community and City Hall, are not all powerful. Activists dispute EIS conclusions, put initiatives on the ballot, and run for City Council seats. Activists have successfully challenged what Molotch calls the "growth imperative." Activists specifically tied downtown development to negative externalities like congestion and displacement. Seattle fits Dahl's model of dispersed influence, at least in the 1980s. Pro-growth interests do not have a monopoly on resources and cannot silence the opposition. This does not mean that Elkin's urban regime model is wrong. There will always be a natural affinity between downtown business associations and City Hall. Even relatively independent bureaucracies are negotiating from a position of weakness when professional norms conflict with the bottom line. Almost all politicians run on a pro-business platform or at least sidestep the issue. But we can thank Seattle for showing us that fundamental issues can be raised and the business agenda can be expanded.

On a darker note, the Portland case studies indicate that unless activists make it to the ballot box, and unless the public interest can be framed in terms of public interest rather than urban regime interest, "citizen participation" rhetoric becomes 
camouflage for elite decision-making. The Portland regime is more inclusive than the old Seattle regime, but that broader base reduces the potential for an alternative decision-making process through electoral politics. The tight network of relationships in Portland means that business interests must at least listen to social service members of the regime. This is generally a quiet discussion, away from the public spotlight. In the absence of specific public discussion, quasi-public agencies such as the Portland Development Commission create the dominant policy environment. Citizens are not asked to prioritize downtown development in relation to other public expenditures. Funding and policies are not subject to general debate. Discussion of the public interest is reduced to regard for fair procedures, that is, impartial government selection of private investors, within the general context of private property. Seattle's past conflict and cool relationships leads to more open conflict. Factions turn often to local election to determine politics outcomes. For example, CAP specifically asked Seattle voters to balance growth costs against benefits. This makes for more open politics. Seattle grass roots organizations, like Vision Seattle, have no counterpart in Portland.

Portland's elite may be enlightened but it is not democratic. There is no room for debate on the fundamentals in Portland.

\section{DIRECTIONS FOR FURTHER RESEARCH}

Suburban growth remains the dominant and yet unconquered threat to downtown primacy. In November, 1990, elections in both 
metropolitan regions revealed the strength of the Portland urban regime and the weakness of the regime in Seattle. A major difference between Portland and Seattle is the role of the central city vis a vis the metropolitan region. Although both cities are becoming politically weaker in comparison to the suburbs, Portland is engaged in an effort to contain the region and refocus it upon the center. The containment of sprawl and increased city density is in Portland's interest. Oregon's statewide land-use planning system allows Portland city planners to legitimately explore issues such as suburban sprawl. In Washington, Seattle has just embarked upon a quest to harness new statewide growth legislation.

The Oregon elections in November, 1990, provided a rare referendum on the ruling regime's organizational and strategic tools regarding growth and regional development. The voters approved three measures: Measure 1 granted Metro the right to "selfgovernance" through adoption of a home-rule charter. This measure confirmed the increasing tendency to seek "regional solutions." Passage of Tri-Met measure 26-1 allowed Tri-Met to expand the light rail system from downtown to suburban Washington County to the west. Measure 5 slashed local government property taxes and inadvertently put a lid on tax increment revenue.

Measure 1 mandates regional planning through Metro. However, this is carefully limited by placing local governments in an oversight position. Local governments will decide which functions Metro will take on. A committee of local governments must approve the tasks that Metro takes on. These will be those tasks such as the 
downtown arts complex which the city wishes to share the burden of funding.

Tri-Met measure 26-1 passed by a 2-1 margin despite the simultaneous passage of a property tax limitation. The light rail measure included $\$ 110$ million for the construction of a Washington County link and \$15 million for engineering and right-of-way acquisition of a North Portland/Clackamas County line. The measure was a referendum on the region's light rail program and its role in shaping future regional growth. Supporters argued that light rail is a fast, quiet, environmentally sound alternative to highways and a weapon against suburban sprawl. Opponents argued that the project was a "boondoggle" which would benefit only downtown business interests and suburban developers. This election was critical for the success of the project. The federal/local match of $75 / 25$ could not be assured beyond this election date. Passage of this measure was essential to continue to build the system and move toward a grand growth management strategy of a structured metropolitan region with downtown the dominant center. Growth is directed along light rail lines and at the hub of the light rail network, downtown Portland. Metro operates the UGB, Tri-Met operates the light rail network and the City of Portland promotes downtown growth in urban renewal districts using tax increment financing to fund public improvements. In addition to the $\$ 110$ million, Tri-Met secured \$99 from the Oregon Legislature and \$21 from local governments to meet the local match. Local match for transit will 
be more difficult as the federal government will no longer put up 75 percent.

Passage of Measure Five limited property taxes and inadvertently the revenue which the Portland Development Commission needs to implement urban renewal. After failing to get court exemption from this limit, the city is pursuing an amendment to the state constitution.

On balance, it appears that the Portland regime is succeeding in its pursuit of regional policies which benefit the center.

In Washington state, voters rejected a growth management initiative sponsored by Citizens for Balanced Growth - Puget Sound environmentalists - which promised to establish strict limits on growth, creating a state agency whose mission would be similar to LCDC's. This was an outsider's movement. Initiative 547 would have set up a state panel to review local growth management plans, institutionalizing a protectionist vision of the environment, imposed development-impact fees and given local citizens more power to contest developments. Developers raised over $\$ 627,657$ compared to $\$ 161,600$ raised by initiative supporters as of one month before the election. 7 Voters rejected an Oregon approach by a 2-1 margin. Instead, the Washington Legislature did pass a limited growth management measure but the effect this will have on redirecting growth toward the city is still unclear. Washington voters consistently reject any statewide planning system which would limit the ability of suburbanites to escape central city problems. 
In the mass transit arena, the Rail Transit Plan (RTP) is poised to have King, Snohomish and Pierce Counties endorse its $\$ 9.3$ billion, 120 mile, heavy rail transit plan to the voters:

Back in the Boeing Boom the Legislature insisted that Pierce, King, and Snohomish counties yoke together a plan. That idea made planning sense, but politically it meant that a swarm of politicians had to deliver goodies to their voters. In short order, the scheme got loaded up like a Christmas tree with extensions, commuter-rail lines, HOV lanes, road-widening, urban jitneys, and transit stops. Needing to have voter approval from three counties meant the rail line had to be far-flung right from the first. The cost went through the roof before anyone really noticed. 8

A proposal of such enormous scale is in keeping with the "Seattle spirit." The response was in keeping with our research. The Washington Environmental Council, the Sierra Club and a private consulting firm, Petrie Transit Consultants, appealed the EIS statement. The environmental groups questioned the impacts on air quality and energy consumption. Although the appeal was denied on April 19, 1993 the project is not yet scheduled for a vote. In additional to environmental objections that the project is too grandiose, neighborhoods fear that the project will tear up neighborhoods like Capitol Hill, where an enormous tunnel is proposed. The Seattle Weekly considers it a boondoggle. The planners have already rejected compromises put forward by ad hoc activist groups such as SMART who call for a small system to be added upon later (just like Portland's MAX). 9

Thus, Portland and Seattle seem to be continuing their divergence at a much larger, regional scale. We can continue our basic research into the potential for a regional-scale downtown- 
focused urban regime and the increased difficulty of incorporating citizens into decision making, much less getting projects done. An interesting question in further research would be to ask how downtown growth coalitions cooperate with the environmental movement in stopping "edge city" development. How are downtown coalitions reacting to the challenge of the increasingly diffused suburban centers of influence?. How does the state value its relationship with sub-entities whose purposes cross?

Portland's past success does not ensure continued effectiveness in the regional realm just as Seattle may not continue to stumble. The late 1960 s and early 1970 s were a golden era of coalitions of grass roots activists and the civic elite in both cities. In our study period, 1972 through 1992, city politics shifted to an urban regime which either didn't need or didn't want grass roots activist involvement. Now, both cities face an uncertain future in a metropolitan, global world. The task is to redirect private and public investment to effectively compete, yet avoid further degredation of the environment. If the urban regime respects the integrity of willing activist partners, democracy and the lives of our metropolitan citizens will benefit. 10 
1Pacific Development Inc. is in the process of selling its properties on the eastside. A recent decision to hold off an office tower project has left the city with several million dollars invested without much tangible return.

2The passage of property tax limitation Measure 5 has placed a lid on local property tax assessments. Portland can no longer exclude increment revenue from property taxes from the limit. PDC's budget is suddenly visible and subject to new political pressures.

3Frederick-M. Wirt, Power in the City Decision Making in San Francisce, Berkeley, University of California Press, 1974. Wirt divides San Francisco politics into the "politics of profit" (downtown redevelopment) and the "politics of deference" (ethnic rivalry). City politics results from history and external influences. This dissertation has picked Portland and Seattle to factor out national influences, both economic and political, leaving history and state and regional constraints on the two cities.

${ }^{4}$ Elkin, City and Regime in the American Republic, Chicago: University of Chicago Press, 1987, pp. 81-82. Elkin seems to stop at the distinction between a commercial private interest (bias) and the public commercial interest (the commercial republic). I think that much of the conflict in Seattle is motivated by progressive concern over the use of space being subverted for its exchange value. The concerns of Lefebre seem to motivate the most progressive of Seattle-ites. Portlanders seem to feel that the Downtown Plan successfully melded use and exchange values.

5 Norbert MacDonald, Distant Neiahbors, p. 170.

6 Note that formal institutional structures do not explain why Portland activists do not put initiatives on the ballot.

7 Linda Yoshikawa-Cogley, "Anti-547 spending outpaces rival group," Seattle PostIntelligencer, October 17, 1990. Linda Yoshikawa-Cogley, "Voters rejecting initiative on growth control," Seattle Post-Intelligencer, November 7, 1991.

${ }^{8}$ Seattle Weekly, "Our Two Cents: Derailing the RTP," April 28, 1993.

${ }^{9}$ Seattle Times, "Transit appeals rejected," April 20, 1993. Seattle Weekly, "A KING special: Too cozy with Metro," April 21, 1993.

10In 1983, Carl Abbot summed up his history of planning, politics and growth in Portland by noting that: "The future [of planning] will belong to leaders who can bring together grassroots activists and members of the civic elite in new coalitons for the improvement of Portland's metropolitan environment and the lives of its citizens." Portland, p. 277. 


\section{RERERENCES}

\section{A. Manuscript Collections}

Portland City Archives, Portland, Oregon.

Neil Goldschmidt, Commissioner's Files (1971-72)

Neil Goldschmidt, Mayor's Files (1973-79)

Portland City Council Documents

Portland Planning Bureau Papers: Project Files

Portland Development Commission Papers: Project Files

Seattle City Archives, Seattle, Washington.

Charles Royer, Mayor's Files (1984-1989)

B. Minutes and Annual Reports

Portland City Council. Proceedings, 1963-90.

Resolutions, 1958-90.

Portland City Planning Commission. Minutes, 1958-90.

Seattle. City Council. Proceedings, 1963-90.

C. Periodicals and Newspapers

Business Journal. 1979-1992.

City Club Bulletin. City Club of Portland. 1971-1992.

Counterpoint. (Seattle). 1986.

Oregon Journal. 1979-1982.

Oregonian. 1955-1992.

Northwestern Arts. (Seattle). 1986.

Seattle Argus. 1965-1972. 
Seattle Post Intelligencer. 1975-1992,

Seattle Times. 1959-1992.

Seattle Weekly. 1973-1992.

The Forum. Vision Seattle. 1989.

Willamette Week. 1979-1992.

D. Planning Reports and Government Documents

Abbott, Norman A. "Memorandum to Earl Blumenauer, Commissionerelect. Central City Plan Options." Portland: December 29, 1986.

Allied Arts of Seattle. Downtown Committee. Recommendations for the Downtown Seattle Comprehensive Land Use and Transportation Plan. Seattle: 1981.

American Institute of Architects, Portland Chapter. A Visual Survey of Downtown Portland. Portland: 1971.

American Institute of Architects, Seattle Chapter. Action: Better City. Seattle: 1968.

American Institute of Architects. Region-Urban Design Assistance Team. Last Place in the Downtown Plan. Portland: May, 1983.

Association for Portland Progress. Five Year Strategic Plan. Portland: January, 1991.

Barnes, Rebecca. Letter. "Rouse Westlake Project Schematic Design Review by Interdepartmental Design Review Group." Seattle: April 7, 1986.

Bogue, Virgil G. Plan of Seattle. Report of the Municipal Plans Commission submiting report of Virgil C. Bogue, Engineer. Seattle: 1911.

Cadillac Fairview U.S., Inc. Proposed Morrison Street Downtown Development. Wilmington, Delaware: 1979.

Central City Plan Pre-Planning Committee. Central City Plan: Adopted Planning Process. Portland: July, 1984. 
Central City Plan Process Subcommittee. Central City Plan. Proposed Process Refinements. Portland: September, 1985.

Central Seattle Community Council Federation. Final Environmental Impact Statement for the Land Use and Transportation Plan For Downtown Seattle. Seattle: 1984.

CH2M-Hill and DeLeuw, Cather and Company. Inventory and Analysis: Downtown Plan. Portland: 1971.

Chamber of Commerce. Final Environmental Impact Statement for the Land Use and Transportation Plan For Downtown Seattle. Seattle: 1984.

Citizens Alternative Plan. The Citizens' Alternative Plan A Summary of the Proposed Ordinance Presented to the Seattle City Council September 14. 1988. Seattle: 1988.

Citizens Steering Committee. Final Report and Recommendations, Citizen Steering Committee. Portland: May 7, 1987.

City Club of Portland. "Report on the Impact of Building Heights in Portland." City Club Bulletin Vol. 55. No. 42. March, 1975.

"Report on the Need for Community Goals." City Club Bulletin Vol. 54. No. 5. June 29, 1963.

City of Seattle and the Central Association of Seattle. Exploring Ways of of Developing a Better Downtown Seattle. Seattle: October, 1959.

Planning the Future of Seattle's Central Area--A Joint Policy Statement. Seattle: May, 1959.

Research Highlights--Background for a Comprehensive Plan for Central Seattle. A Joint Report. Seattle: November, 1959.

Clark, Mayor Bud J.E. and Commissioner Earl Blumenauer. "Letter to Harry Demorest and Patrick L LaCrosse." April 18, 1990

Cline, Scott. Office of the Comptroller. City of Seattle Municipal Archives Program. Guide to the Archives of the City of Seattle. Seattle: 1988. 
Decision Sciences, Inc. Portland Residents Discuss Community Values. A Quantitative Research Project Prepared for: Policy Group of Portland Future Focus. Portland: June, 1990.

Denny Regrade Property Owners Association. Final Environmental Impact Statement for the Land Use and Transportation Plan For Downtown Seattle. Seattle: 1984.

Downtown Human Services Commission. Downtown Housing for the Low-Income: A Crisis. Seattle: 1985

Downtown Neighborhood Alliance. Final Environmental Impact Statement for the Land Use and Transportation Plan For Downtown Seattle. Seattle: August, 1984.

Downtown Neighborhood Association. The Downtown Boom. A Special Report from the DNA on the Untold Costs of Highrise Development. Seattle: 1981

Downtown Seattle Association. Final Environmental Impact Statement for the Land Use and Transportation Plan For Downtown Seattle. Seattle: 1984.

Citizens For a Better Downtown Statement of Purpose. Seattle: February 1, 1989.

Downtown Seattle Development Association There's No Place Like This Place Anyplace. Blue Book of Downtown Seattle Association. Seattle: 1990. Housing Subcommittee "Firm Alternatives: Recommended by the Urban Design Seattle: Subcommittee" Seattle:

Duchek, Bill. "Assignment of Floor Area Bonus Values for Downtown Public Benefit Features." Memorandum to Rich Yukubousky, Director Land Use and Transportation Project. Seattle:

Elway Research, Inc. 1989 Puget Sound Leadership Conference of Survey Findings. Seattle: May, 1988. Downtown Development Survey. Seattle: November, 1989. 
Emergency Housing Coalition. Final Environmental Impact Statement for the Land Use and Transportation Plan For Downtown Seattle. Seattle: 1984.

Environmental Works/Community Design Center. Seattle Housing Affordability Background Report. Seattle: November, 1989.

ERA Associates. Westlake Mall: Economic Evaluation of Proposed Seattle Art Museum. Seattle: 1977.

Functional Advisory Committees, Central City Plan. Final Reports: Phase 1I. September, 1986.

Hodge, David. Seattle Displacement Study. City of Seattle Office of Policy Planning. Seattle: March, 1979.

Housing Advisory Committee. Downtown Housing Policy and Program. Portland: October 3, 1979. Local Options for Funding Low- Income Housing. Portland: April, 1987.

Housing Advisory Group. Interim Report on the Housing Management Plan. Portland: January, 1990.

Housing Advocates. Final Environmental Impact Statement for the Land Use and Transportation Plan For Downtown Seattle.

Housing Authority of Portland. Breaking the Cycle of Homelessness. Master Plan Agreement. Portland: May, 1989.

- Resolving Homelessness in Portland and Multnomah County. A Report and Planning Framework. November, 1989.

International Community Development Association (ID), Final Environmental Impact Statement for the Land Use and Transportation Plan For Downtown Seattle. Seattle: 1984.

International Special Review District, Final Environmental Impact Statement for the Land Use and Transportation Plan For Downtown Seattle. Seattle: 1984. 
John M. Sanger, Future Development in Downtown Seattle Prepared for the City of Seattle Office of Policy and Evaluation.

Seattle: November, 1980.

John Spencer Associates. Development Regulation Techniques in the Central City. Portland: March, 1987.

Jones, Casey, and Michael Hildt. "1977 budget report - OPP and the Comprehensive Policy Plan." Memorandum to Seattle City Council, November 8, 1977.

Karen Myers \& Associates. Central City Planning Area Housing Study. Final Report. Portland: April, 1986.

Single-Room (SRO) Housing Study. Central City Planning Area. Portland: September, 1986.

Central City Planning Area Office Market Study: Final Report. Portland: March, 1986.

League of Women Voters. Final Environmental Impact Statement for the Land Use and Transportation Plan For Downtown Seattle. Seattle: 1984. Neighhborhood Planning in Seattle. Seattle: May, 1990.

Leland and Hobson. North of Burnside Study: Analysis of Economic Impacts: Assessment of Development Potentials. Portland: September, 1980.

Livingston and Blayney et. al. Alternative Approaches to Downtown Portland Development Regulations. Portland: April, 1974.

Downtown Portland Proposed Development Regulations Portland: November, 1974.

Lord and LeBlanc. Economic analysis of the Portland Downtown Guidelines Plan: Qutlook and Recommendations for Implementation. July, 1974.

McLerran, Dennis J. Director, Department of Construction and Land Use "Director's Report on Downtown Interim Controls. Memorandum to Coucil member Paul Kraabel, Chair Urban Redevelopment Committee." Seattle: March 2, 1989. 
Metropolitan Service District. Regional Urban Growth Goals and Objectives. Review Draft. Portland: August, 1990.

Mondev International. Westlake Park. Seattle: 1976.

Monson, Donald, Planning Consultant. Comprehensive Plan--Central Business District. Technical Report. Seattle: February, 1963.

Mundy, Bill. Downtown Seattle: A Neighborhood Viability Study for the Downtown Seattle Development Asociation. Seattle: June, 1981.

Narramore, Bain, Brady and Johanson and Fred Bassetti and Company. Westlake Park Feasibility Study. Seattle: August, 1974.

Northwest Strategies. Report to Central City Plan Steering Committee on Design Event One. Portland: July, 1985. The Central City Today. Portland: June, 1985. Portland: Give Us Your Dreams to Build a Plan On. Portland: May, 1986.

Owens, Jim. "Portland's Central City Plan: An Annotated and Unfinished History of Its Process." Arcade. December 1987/January 1988.

People for Downtown Housing. Final Environmental Impact Statement for the Land Use and Transportation Plan For Downtown Seattle. Seattle: 1984.

Pike Place Market Constituency. Final Environmental Impact Statement for the Land Use and Transportation Plan For Downtown Seattle. Seattle: 1984.

Pike Place Market Historical District. Final Environmental Impact Statement for the Land Use and Transportation Plan For Downtown Seattle. Seattle: 1984.

Pike Place Market Preservation \& Development Authority, Final Environmental Impact Statement for the Land Use and Transportation Plan For Downtown Seattle. Seattle: 1984. 
Pike Place Merchants Association. Final Environmental Impact Statement for the Land Use and Transportation Plan For Downtown Seattle. Seattle: 1984.

PMC Associates. Portland: A Balance of Interest in Public Private Cooperation. Prepared for the Committee for Economic Development. Palo Alto, CA: September, 1981.

Portland Future Focus. Bridging to the New Century. Portland: April, 1990.

Portland. Bureau of Planning. Central City Plan. Urban Design, Land Use and Historic Preservation (Draft). Portland: June, 1986. Downtown Design Guidelines. Portland: 1983.

Analysis of Potential Central City Housing Implementation Strategies. Portland: June, 1986.

Central City Plan. Portland: March, 1988.

Central City Plan. Report and Recommendations on City Form. Portland: May, 1987.

Central City Plan: Choices for the Future. Portland: February, 1987.

Central City Plan: Phase II Staff Report. Portland: August, 1986.

- Compatible Infill Analysis Development. Portland: June, 1986, Comprehensive Downtown PlanParking Planning Concepts Portland: June 25, 1962.

__ Comprehensive Plan. Portland: October, 1980. Downtown Plan and Program Rudy Brunner Application. Portland: December, 1972.

Downtown Plan Inventory and Analysis. Portland: September, 1971. 
Downtown Portland Planning Concepts. Portland: September, 1964.

Eastbank Esplanade Report. Portland: June, 1963.

"Essential Service Providers. Memorandum to Kathryn Imperati." Portland: December 8, 1988.

Final Reports. Functional Advisory Committees. Central City Plan. Phase II. Portland: September, 1986.

Historic Preservation in Portland: Focus on the Central City. Portland: June, 1986.

Housing in the Central City Plan. Portland: March, 1987. Land Use Findings Central City Plan (Draft). Portland: July, 1986.

Morrison Street Project Competition. Summary Report to the Portland Development Commission. Portland: 1983.

North of Burnside Implementation and Management Program. Portland: August, 1982.

North of Burnside Land Use Policy. Portland: May 14, 1981, reprinted March, 1986.

North of Burnside Study. Portland: September, 1980.

North of Burnside Supplemental Report. Portland: May14, 1981.

Northwest Triangle Report. Portland: August, 1985.

Northwest Triangle Study Background Report. Portland: May, 1984.

Planning Guidelines Portland Downtown Plan. Portland: December, 1972.

__ Report on Public Review Period 2. Portland: April, 1987. 
Status Report on Low Income Single Room Occupancy (SRO) Housing in Downtown Portland. Portland: March, 1986, reprinted September, 1986.

Portland. City Council. Resolution 34286 (adopting Memorandum of Agreement between Don Clark and Roger Shiels). Portland: May $5,1987$.

Portland. Housing Advisory Committee. Proposed Oregon Housing Trust Fund. Portland: January, 1985.

Portland. Human Resources Bureau. Social Policy Report for the Downtown Urban Renewal Area. Portland: November 26, 1974.

Portland. Office of Planning and Development and Bureau of Planning. North of Burnside Study: Analysis of Economic Impacts :Assessment of Development Potentials. Portland: September, 1980.

Portland. Office of Planning and Development and Portland Development Commission. Downtown Housing Inventory. Portland: April, 1978.

Portland. Office of Planning and Development. An Analysis of Administrative and Policy Alternatives Prepared for the Portland Development Commission. Portland: November 25, 1977. - Progress Report on the Downtown, 1977-1979. Portland:

Study of Morrison Street Development Proposal. Portland: December, 1979.

Portland. Office of the Mayor. Breaking the Cycle of Homelessness: The Portland Model. Portland: Revised September, 1988.

Portland. Portland City Planning Commission. Amendment to the Downtown Waterfront Urban Renewal Plan--Acquistion of Beaver and Estate Hotels. Portland: November 12, 1985. Downtown Housing Preservation Program. Planning Commission Agenda: 592. February 12, 1990 
Portland Downtown Plan Inventory and Analysis. September, 1971.

Portland. Portland Development Commission. Action Plan for Downtown Retail Development in Portland. Oregon. Portland: June, 1981.

Background Paper. Portland Development Commission and the Morrison Street Downtown Development Project. Portland: November, 1979.

Central City Plan. Briefing Paper \#1: Population and Household Trends in the Portland Metropolitan Area 1970 to 1990. Portland: February, 1986.

Central City Plan. Briefing Paper \#2: Employment and Economic Trends in the Portland Metropolitan Area 1960 to 2005. Portland: March, 1986.

Central City Plan. Briefing Paper \#3: Historic and Current Office Space Development Trends in the Portland Metropolitan Area. Portland: March, 1986.

Central City Plan. Briefing Paper \#4: Historical and Current Retail Activity in the Portland Metropolitan Area. Portland: March, 1986.

Central City Plan. Briefing Paper \#5: Convention and Tourism Activity in the Portland Metropolitan Area. Portland: March, 1986.

Central City Plan. Briefing Paper \#6: Small Business Incubators. Portland: April, 1986.

_ Central City Plan. Briefing Paper \#7: Basic Industry in the Portland Metropolitan Area. Portland: April, 1986.

Central City Plan. Briefing Paper \#8: The City of Portland's Industrial Sanctuary Policy. vApril, 1986.

Development Guidelines for the Morrison Street Project. Portland: 1981

Downtown Housing Policy and Program. Portland: 1979. 
Downtown Portland Project Reference File. Portland:

August, 1986.

Downtown Program. Portland: March, 1981.

North Downtown Redevelopment Program Portland: February, 1986.

Qutlooks and Options for the Morrison Street Project. Portland: 1979.

The Morrison Street Project. A Portland Development

Commission Request For Proposals. Portland: August, 1982.

Urban Renewal Plan for the Downtown Waterfront Urban

Renewal Project. Portland: April 25, 1974.

Urban Renewal Plan for the Downtown Waterfront Urban

Renewal Project. Fourteenth Amendment. Housing

Rehabilitation and New Construction. Portland:

Urban Renewal Plan for the Downtown Waterfront Urban Renewal Project. Morrison Street Project Redevelopment Activities. Portland: December, 1986.

Urban Renewal Plan for the Downtown Waterfront Urban Renewal Project. Ninth Amendment. Low Income Hotel and Social Service Center. Portland: Rescinded January 1986.

Urban Renewal Plan for the Downtown Waterfront Urban Renewal Project. Seventh Amendment. Portland: September 2, 1981.

Urban Renewal Plan for the Downtown Waterfront Urban

Renewal Project. Seventh Amendment. September 2, 1981.

Urban Renewal Plan for the Downtown Waterfront Urban

Renewal Project. Sixth Amendment. South Waterfront and

Pioneer Square Redevelopment Activities. Portland:

September 13, 1979.

Portland. Portland Historical Landmarks Commission. How Do We Know It Is Us Without Our Past? Portland: January, 1974. 
Puget Sound Council of Governments. Growth and Transportation Seattle: September, 1989

Population and Employment Forecasts King County. Seattle CBD. Seattle: June, 1988.

Population and Employment Forecasts, 1990-2000-2020. Seattle: June 1988.

Vision 2020 Growth Strategy and Transportation Plan for the Central Puget Sound Region. Draft Environmental Impact Statement. Seattle: April, 1990.

Vision 2020 Region at a Crossroads: Time to Choose.. Seattle: May, 1990.

Ranier Club, Final Environmental Impact Statement for the Land Use and Transportation Plan For Downtown Seattle. 1984.

Rouse. Westlake Project Prospectus. Seattle: August, 1982.

Royer, Charles. Office of the Mayor. "Letter to Seattle City Employees." Seattle: January, 1989.

"Proposed revisions to the Downtown Land Use and Transportation Plan as Alternative Ballot Measure." Seattle: November 29, 1988

"Citizen's Alternative Plan." January, 1989.

On the Issues. Westlake Mall. Seattle: March 17, 1977.

Seattle City Council. "Central Staff Report on Downtown Growth Issues." Seattle: August 14, 1984.

Seattle City Council Memorandum. Notice of Public Hearing Regarding the Creation of a New Department of Neighborhood Services. Seattle: August 9, 1990.

Seattle Displacement Coalition. Downtown Boom. Seattle: n.p., n.d.. Final Environmental Impact Statement for the Land Use and Transportation Plan For Downtown Seattle. Seattle: 1984. 
Seattle Economic Development Commission and Seattle Planning Commission. Proceedings of the Symposium on Planning for Growth in Seattle Seattle: October 5, 1988.

Seattle League of Women Voters. Neighborhood Planning in Seattle. Seattle: May, 1990

Seattle City Council. Resolution 27909. A resolution declaring the intent of the Mayor and City Council to re-examine and revise the Land Use and Transportation Plan for Downtown Seattle. and establishing a schedule for the plan review process. Seattle:

Seattle. Office for Long-range Planning, Commercial Development in Seattle. Seattle: December 1, 1989.

Analysis of Alternatives in Response to the Moratorium on Downtown Low-Income Housing Demolition. Seattle: March, 1989.

Commercial Development in Seattle Current Research Bulletin Number 49. Seattle: December 1, 1989.

Design Review Analysis of Options. October 1, 1988 Downtown Development Survey. November 1981

Residential Demolitions in Seattle: A Study of Household and Unit Characteristics. November, 1988.

Residential Development in Seattle, 1980-1987. Current Research Bulletin Number 48. Seattle: July, 1990.

Residential Development in Seattle, 1987-1989. Current Research Bulletin Number 50. Seattle: July, 1990. Seattle Residential Development Report 1980-1987. Current Research Bulletin Number 48. Seattle: July, 1988.

Seattle, Office of Management and Budget. "The Future of Comprehensive Land Use Planning in the City of Seattle," Seattle: July 1988. 
Seattle, Office of Policy Planning. Displacement Report; Executive Summary.

Seattle. Citizen Alternative Plan, Initiative 31, Comptroller File Number 296826, Seattle: November 21, 1988.

Seattle. City Planning Commission and Central Association. Pioneer Square. Seattle: August, 1961.

Seattle. Department of Community Develoment. Westlake Prospectus. Seattle: 1975.

Seattle. Department of Community Development Housing Division Draft 1991 Housing Assistance Plan. Seattle: August 27, 1990.

Seattle. Department of Community Development, Parks and Recreation Department and Law Department. Westlake Park Feasibility Study Seattle: August, 1974.

Seattle. Department of Community Development. 1987 Annual Report. Seattle: 1987.

Contract for Sale of Property. Seattle:

Draft 1991 Housing Assistance Plan. Seattle: August 27, 1990

Housing at Risk: Interim Report on Federally Assisted LowIncome Housing. Seattle:

Pike Place. Seattle: August; 1971.

Pike Place.Market Historical District Preservation Plan Seattle: January, 1973.

Planning for Downtown Seattle - Background. Seattle: December, 1973.

Planning for Downtown Seattle - Concept. Seattle: December, 1973.

Planning for Downtown Seattle - Introduction. Seattle:

December, 1973. 
Planning for Downtown Seattle--Downtown Boulevard. Seattle: May, 1973.

Revised Westlake Environmental Impact Statement. Seattle: 1978.

Seattle Housing Levy Program. Downtown Housing Preservation Program. 1991-1992. Seattle: 1992.

Seattle's Downtown Housing. Inventory. Analysis and Recommendations. Seattle: July, 1989.

Special Needs and SRO Housing Production Program, '88-'89. Seattle:

The Guidelines. Pike Place Market Historical District. Seattle: January, 1974.

_Urban Renewal Plan. Pike Place Project. Amended - 1973. Seattle: 1973

Westlake Environmental Impact Statement Seattle: 1977. Westlake Project Prospectus. Seattle: August, 1982. Westlake Prospectus Environmental Impact Statement. Seattle: 1986.

Westlake Prospectus. Seattle: August, 1982 Westlake 1982 Request for Proposal. Seattle:

Seattle. Department of Construction and Land Use. Director's Rule 16-89 Public Benefit Features: Guidelines for EvaluatingProjects. Administrative Procedures and Submittal Requirements in Downtown Zones Seattle: November 2, 1989.

Seattle. Department of Parks and Recreation. Westlake Draft Environmental Impact Statement. Seattle: February, 1979.

Westlake Final Environmental Impact Statement. Seattle: May, 1979. 
Seattle. Downtown Transit Project. The Downtown Transit Project Preferred Alternative. Seattle: November, 1983.

Seattle. Land Use \& Transportation Project. Background Report of the Downtown Land Use and Transportation Project. Seattle: March, 1981.

Downtown Alternative Plan Guidelines for Alternative Plans. Seattle: May, 1982.

Draft Environmental Impact Statement for the Land Use and Transportation Plan for Downtown Seattle. 2 vols. Seattle: October, 1983.

Draft Land Use \& Transportation Plan for Downtown Seattle. Seattle: Seattle: June, 1983.

Final Environmental Impact Statement for the Land Use and Transportation Plan For Downtown Seattle 2 vol.. Seattle: August, 1984.

Land Use \& Transportation Plan for Downtown Seattle. Adopted June 10,985 by Resolution 27281. Seattle: June, 1985.

Mayor's Recommended Land Use \& Transportation Plan for Downtown Seattle. Seattle: May, 1984.

1982 Downtown Alternative Plan. Seattle: May, 1982.

Stalking the Elusive FAR: A Guide to Downtown Building Densities Seattle: June, 1984.

Summary of the Land Use \& Transportation Plan for Downtown Seattle. Adopted June 10,1985 by Resolution 27281. Seattle: June, 1985.

Summary of the Mayor's Recommended Land Use \& Transportation Plan for DowntownSeattle. Seattle: May 1984. Downtown Housing Issues. Seattle:

Draft Environmental Impact Statement._Seattle: October, 1983. 
Draft Land Use and Transportation Plan for Downtown Seattle. Seattle: June, 1983.

Final Environmental Impact Statement for the Land Use and Transportation Plan for Downtown Seattle. 2 vols. Seattle: August, 1984

Final Environmental Impact Statement. Seattle: August, 1984 Guidelines for Alternative Plans. Seattle: August,, 1981. Land Use and Transportation Plan for Seattle. Adopted June 10. 1985 by Resolution 272281. Seattle: June 10, 1985. Mayor's Recommended Land Use and Transportation Plan for Seattle._Seattle: May, 1984. Summary of the Mayor's Recommended Land Use and Iransportation Plan for Seattle. Seattle: May, 1984.

Seattle. Mayor's Reorganization Project. Final report to the mayor: Mayor's Reorganization Project: Phase 1 - Study of executive department. Seattle: June 1.

Final report to the mayor: Mayor's Reorganization Project: Phase II - Line department organization. Unpublished report, Seattle:

Seattle. Municipal Code, Chapter 22.210. 22-29. Seattle: 1990.

Seattle Municipal Code Table for Section 23.49.050 B Public Benefit Feature Area Bonuses. 23-294 - 23-325. Seattle: 1989.

Seattle. Office of Human Services. Land Use Planning and Social Services Planning for Downtown Seattle. Seattle: January 27, 1982.

Seattle. Office of Long-Range Planning. Analysis of Alternatives in Response to the Moratorium on Downtown Low-income Housing Demolition. Seattle: March, 1989. 
Analysis of Effects of the CAP Initiative on the location of new office development: A report to City Council. Seattle: December 1, 1989.

Commercial Development in Seattle Current Research Bulletin Number 49. Seattle: December 1, 1989.

Comprehensive Plan Framework Policies. Executive Summaries. Population and Human Needs. Housing. Transportation. Economy and Employment. Environment. Community Services and Facilities. Public Utilities. Background Paper. Seattle: December, 1990.

Design Review Analysis of Options. Seattle: October, 1988. Growth and Change. Seattle and the Region. A Background Report for the Advisory Forum on Balanced Growth. Seattle: January, 1989.

Growth Management Policy Paper \#13, Seattle's Retail Sector: Trends. Implications and Policy Recommendations Seattle:

Proceedings of the Symposium on Practical Tools for Downtown Growth Management. Seattle: December, 1989.

Seattle. Office of Policy and Evaluation. Background Report of the Downtown Land Use \& Transportation Project. Seattle: March, 1981.

Seattle. Office of Policy Planning and City Council Policy Staff. Growth Management Policy Paper \#2. Seattle: May, 1976.

Seattle. Office of Policy Planning. Annotated Bibliography City of Seattle Planning Publications 1911-1977. Seattle:

_ Seattle's Growth Policies. Seattle: May, 1977.

Seattle. City Council Ordinance 114428. "An Ordinance relating to land use and zoning, enacting interim zoning controls in certain downtown zones pending the adoption of permanent controls for zoning the downtown area." Seattle: March, 1989

Seattle Planning Commission. Sumary Forum II Planning Reorganization. Seattle: September 26, 1985. 
Sumary Forum III Planning Reorganization. Seattle: October 1, 1985.

Seattle. State Environmental Policy Act of 1971. Ordinances. Chapter 25.04 Seattle Municipal Code. Seattle: 1992

Seattle Shorelines Coalition. Final Environmental Impact Statement for the Land Use and Transportation Plan For Downtown Seattle Seattle: 1984.

Seattle 2000 Action Inventory. An Inventory of City Actions Related to the Seattle 2000 Goals. 1973-1984. A Staff Report to the Seattle City Council Final Working Draft. Seattle. May, 1985.

Seattle 2000 Commission. Goals for Seattle. Preparted by the Citizens of Seattle and Adopted by the Mayor and the City Council. Seattle: 1973.

Shandler, Irving W. "Portland, Oregon Skid Road Project: Social Policy Recommendations," Diagnostic and Rehabilitation Center, Philadelphia, PA, November 26, 1974.

Sierra Club. Seattle Downtown Plan Firm Alternatives Sierra Club Urban Committee. Seattle: 1981.

Skidmore. Owings \& Merrill. Urban Design Plan and Program Waterfront Renewal Area. Portland: March, 1975.

Smith, Dean S. "Memorandum to Norman A. Abbott, Director. Analysis of Central City Plan Options". Portland: January 12, 1987.

Strachan, Margaret D. "The Central City Plan: Goals and Visions for the Future." Portland: May 25, 1984.

Taoka, Sue. Your City: Seattle Works in the 1990's. Office of the Mayor. Seattle:

The Planning Group. Assessment of Service Needs of Special Populations Within the Central City Area. Portland: April, 1986.

Human Services for Portland's Central City. Portland: April, 1986. 
Literature Review on Needs of Central City Residents and Social Service Users. Portland: April, 1985.

Three Deinstitutionalized Populations. Portland: April, 1986.

University of Washington, Institute of Governmental Research InnerCity Revitalization and Displacement: The Now Urban Future Seattle: 1979.

Vision Seattle. Final Environmental Impact Statement for the Land Use and Transportation Plan For Downtown Seattle.. Seattle: 1984.

- The Vision Seattle Issue Agenda. A Working Statement of the Beliefs and Ideals of the Combined Vision Seattle Membership and Board of Directors. Seattle: September, 1990.

Washington. State Environmental Policy Act of 1971 Chapter 43.21c, Revised Code of Washington. Seattle: 1992.

Waterfront Plan Group. Final Report. Downtown Waterfront Park. Portland:August, 1975.

Summary Report. Portland Downtown Waterfront Development Study. December, 1974.

Waterfront Study - Downtown Portland. December, April, 1972.

West Coast Paper Profit Sharing Trust, Final Environmental Impact Statement for the Land Use and Transportation Plan For Downtown Seattle. Seattle: 1984.

Westlake Advisory Committee. Westlake Final Report. Seattle: 1972.

E. Books and Articles

Abbott, Carl. The New Urban America: Growth and Politics in Sunbelt Cities. Rev. Edition Chapel Hill: University of North Carolina Press, 1987.

Portland: Planning. Politics, and Growth in a Twentieth Century City. Lincoln: University of Nebraska Press, 1983. 
"Regional Cities and Network Cities: Portland and Seattle in the Twentieth Century." Western Historical Quarterly 23.3(1992): 293-322.

"Urban Design in Portland, Oregon as Policy and Process," Planning Perspectives. 6.1 (1991): 1-18.

and Sy Adler. "Historical Analysis as a Planning Tool." Journal of the American Planning Association 46.3 (1989): 467-473.

Andrew, Christine I. and Dwight H. Merrian. "Defensible Linkage." Journal of the American Planning Association 54.2 (1988): 199-209.

Apoduca, Virginia. State of the City: The Crisis in Basic Human Needs. Seattle: Church Council, State of the City Committee, 1986

Bachrach, Peter and Morton Baratz. "The Two Faces of Power." American Political Science Review 56 (1962) 947-52.

Banfield, Edward C. Big City Politics. New York: Random House, 1965.

Barbour, George P., Jr. "Portland, Oregon: A Balance of Interest in Public-Private Cooperation." Public-Private Partnership in American Cities: Seven Case Studies. Edited by R. Scott Fosler and Renee A. Berger. Lexington, Mass.: DC. Heath and Company, 1982: 201-242.

Barnekov, Timothy and Daniel Rich. "Privatism and Urban Development: An Analysis of the Organized Influence of Local Business Elites." Urban Affairs Quarterly 12.3 (1977): 431 60.

Beauregard, Robert A. Atop the Urban Hierarchy. Totowa, N.J.: Rowman and Littlefield, 1989. Ed. Economic Restructuring \& Political Response. Urban Affairs Annual Reviews 34. Newbury Park, Ca: Sage, 1989. 
"The Redevelopment of Capitalist Cities; the Case of the United States. Paper delivered at New Perspectives on the Political Economy Conference, 1981.

"Space, Time and Economic Restructuring." Economic Restructuring and Political Response. Urban Affairs Annual Reviews 34 Newbury Park, CA: Sage, 1989. 209-239.

"Structure, Agency and Urban Redevelopment." Ed. Michael Peter Smith. Cities in Transformation: Class, Capital and the State: Beverly Hills: Sage, 1984. 51-72.

Structural Analysis and Urban Redevelopment." Comparative Urban Research 9.2 (1983): 47-52.

Bender, Thomas. A Report on Politics in Seattle. Cambridge: Harvard - MIT Joint Center for Urban Studies, 1961.

Bernard, Richard M. and Bradley R. Rice, eds. Sunbelt Cities: Politics and Growth since World War II. Austin: University of Texas Press, 1983.

Boyer, M. Christine. Dreaming the Rational City: The Myth of American City Planning. Cambridge: MIT Press, 1986.

"The Return of Aesthetics to City Planning: Future Theory As a Departure From the Past." Paper delivered at Rutgers University Conference. Washington, 31 March 1987.

Brewster, David. "Sweeping Downtown Plan Unites Portland. 34Acre Waterfront Park, Transit Malls, Central Plaza Among Features; Initiative and Generosity from Business Leaders Essential Ingredients." Argus [Seattle]: 3 May, 1972.

Briggs, Catherine. "Downtown Housing: Seattle and Portland." n.p. March 14, 1989.

Burd, Gene. "The Selling of the Sunbelt: Civic Boosterism in the Media." The Rise of the Sunbelt Cities. Ed. David Perry and Alfred Watkins. Beverly Hills: Sage, 1977. 129-150.

Burgess, Ernest W. "The Growth of the City." The City. Eds. Robert Ezra Park, Ernest W. Burgess, and Roderick D. McKenzie. Chicago: University of Chicago Press, 1925. 47-62. 
Castells, Manuel. The City and the Grassroots: A Cross-Cultural Theory of Urban Social Movements. Berkeley: University of California Press, 1983.

City, Class \& Power. Trans. Elizabeth Lebas. New York: St. Martin's Press, 1979.

The Economic Crisis and American Society. Princeton:

Princeton University Press, 1980.

Ed. High Technology. Space and Society. Urban Affairs Annual Reviews. 28. Beverly Hills: Sage, 1985.

"The New Urban Crisis." The Quality of Urban Life. Ed., Dieter Frick. Berlin: Walter deGruyter, 1989.

"Space and Society: Managing the New Historical

Relationships." Cities in Transformation. Class. Capital and the State. Urban Affairs Annual Reviews 26. Ed. Michael Peter Smith. Beverly Hills: Sage, 1989. 235-260.

The Spatial Question. London: Blackwell, 1989.

"Theory and Ideology in Urban Society." Urban Sociology:

Critical Essays. Ed. C.G. Pickvance. New York: St. Martin's Press, 1976. 60-84.

The Urban Question: a Marxist approach. Cambridge: MIT Press, 1979.

Clark, Susan E. and Andrew Kirby. "In Search of the Corpse. The Mysterious Case of Local Politics." Urban Affairs' Quarterly 25. 25.3 (1990): 389-419.

Clavel, Pierre. The Progressive City: Planning and Participation. 1969-1986. New Brunswick: Rutgers University Press, 1985.

Cox, Kevin R. Conflict. Politics and the Urban Scene. New York: St. Martin's Press, 1982. Location and Public Problems. A Political Geography of the Contemporary World. Chicago: Maaroufa Press, 1979. 
Urbanization and Conflict in Market Societies. Chicago: Maaroufa Press, 1978.

Cummings, Scott. "Private Enterprise and Public Policy: Business Hegemony in the Metropolis," Business Elites and Urban Development: Case Studies and Critical Perspectives. Albany: SUNY Press, 1988. 3-25.

Dahl, Robert A. Democracy and Its Critics. New Haven: Yale University Press, 1991.

Dilemmas of Pluralist Democracy: Autonomy vs. Control. (Studies in Political Science: Vol. 3). New Haven: Yale University Press, 1983.

Who Governs? Democracy and Power in an American City. New Haven: Yale University Press, 1961.

Dalton, Linda C. "Politics and Planning Agency Performance Lessons from Seattle." Journal of the American Planning Association. 51.2 (1985): 189-199.

Dartt, Donald. "Portland's Design Review Process: An Introduction and Assessment." Portland: n.p., 1984.

Dear, Michael and Allen J. Scott. Urbanization and Urban Planning in Capitalist Society. London: Metheun, 1981.

Denny, Brewster. "New York Alki: Physical Planning and the Vision of a City." Arcade Seattle: February/March 1989.

Domhoff, G. William. Who Really Rules? New Haven and Community Power Reexamined. New Brunswick, N.J.: Transaction Books, 1977.

Eagin, Michael. Seattle: Renaissance of America's Most Livable City. Seattle: Medium Rare, 1978.

Elkin, Stephen L. "Castells, Marxism and the New Urban Politics." Comparative Urban Research 7.2 (1979): 22-32.

City and Regime in the American Republic. Chicago: University of Chicago Press, 1987. 
"Cities Without Power. The Transformation of American Urban Regimes. National Resources and Urban Policy. Ed. Douglas Ashford. New York: Metheun, 1980. 265-291.

"Pluralism in its Place." The Democratic State. Lawrence: Eds. Roger Benjamin and Stephen L. Elkin University of Kansas Press, 1984.

"Popular Control and Private Interests in American Cities." Paper delivered at a meeting of the American Political Science Association. Chicago, September, 1983.

"Twentieth Century Urban Regimes." Journal of Urban Affairs7 (1985): 11-28.

Fainstein, Norman and Susan Fainstein and P. Jefferson Armistead. "San Francisco: Urban Transformation and the Local State." Restructuring the City: The Political Economy of Urban Redevelopment. Ed. Norman Fainstein. New York: Longman, 1983. 202-243.

Fainstein, Norman I. and Susan S. Fainstein. "Restructuring the American City: A Comparative Perspective." Urban Policy under Capitalism. Urban Affairs Annual Review. 22. Beverly Hills: Sage , 1982. 161-190.

Fainstein, Susan, et. al. eds. Divided Cities: New York and London in the Contemporary World. London: Blackwell, 1991.

Fainstein, Susan and Norman Fainstein, "Economic Restructuring and the Rise of Urban Social Movements," Urban Affairs Quarterl. 21.2 (1986): 187-206.

Fischer, John. "Seattle's Modern-Day Vigilantes." Harpers 238, 1428 (1969): 14-26.

Fox, John, "Bulldozing the poor away" Counterpoint 13 January, 1986: 8 - 15. Downtown Boom. Seattle: n.p., n.d....

Fox, Siegrun F. "Who Opposes Public/Private Financial Partnerships for Urban Renewal?" Journal of Urban Affairs 7 (Winter, 1985) $27-40$. 
Frieden, Bernard. J. "Center City Transformed." Journal of the American Planning Association 56,4 (1990): 423-491. and Lynne B. Sagalyn. Downtown. Inc.: How America Rebuilds Cities. Cambridge: MIT Press, 1989.

Friedland, Roger. Power and Crisis in the City. New York: Schocken Books, 1983.

Fugon, Sharon. Scientists/Citizens Organized on Policy Issues. Impact of Downtown Development on Seattle Housing Cost. Seattle, 1982.

Gluck, Peter R. and Richard J. Meister. Cities in Transition: Social Change and Institutional Responses in Urban Development. New York: New Viewpoints, Franklin Watts, 1979.

Gordon, Margaret T., Hubert G. Locke, Laurie McCutcheon and William B. Stafford. "Seattle: Grassroots Politics Shaping the Environment." Big City Politics in Transition. Urban Affairs Annual Reviews Ed. H. V. Savitch and John Clayton Thomas. 38 Newbury Park, Ca.: Sage, 1991. 216-234.

Gottdiener, Mark R. Capitalist development and crisis theory: Accumulation. Regulation and Spatial Restructuring. New York: St. Martin's Press, 1989.

"Characteristics of Support for Local Growth Control." Urban Affairs Quarterly 17.(1981): 55-73.

Ed. Cities in Stress. A New Look at the Urban Crisis Urban Affairs Annual Reviews 30. Beverly Hills: Sage, 1986.

"Debate on the Theory of Space: Toward an Urban Praxis." Cities in Transformation. Urban Affairs Annual Review 26. Ed. M. Smith. Beverly Hills: Sage, 1984. 199-218.

The Decline of Urban Politics. Political Theory and the Crisis of the Local State. Newbury Park, CA: Sage, 1987. Planned Sprawl: Private and Public Interests in Suburbia. Beverly Hills: Sage, 1977. 
The Social Production of Urban Space. Austin: University of Texas Press, 1985.

"Some Theoretical Issues in Growth Control." Urban Affairs Quarterly 17 (1983): 55-73.

Gottdiener, Mark R. and Max Neiman. "Characteristics of Support for Local Growth Control." Urban Affairs Quarterly 17.1 1981: 55-73.

Gottdiener, Mark R. and Chris G. Pickvance. Urban Life in Transition. Urban Affairs Annual Reviews 39. Newbury Park, Ca: Sage, 1991.

Gunther, John. Inside USA. New York: Harper and Row, 1947.

Hadley, Jane. "The politics of planning in Seattle." Planning $\mathbf{4 9 . 2}$ (1983) $12-17$.

Hartman, Chester. The Transformation of San Francisco. San Francisco: Glide Publications, 1974.

Yerba Buena: Land Grab and Community Resistance in San

Francisco. San Francisco: Glide Publications, 1985.

Hartman, Chester and Rob Kessler. "The Illusion and Reality of Urban Renewal: San Francisco's Yerba Buena Center," Marxism and the Metropolis. Ed. William K. Tabb and Larry Sawers. New York: Oxford University Press, 1978.

Harvey, David. The Condition of Postmodernity. London: Blackwell, 1989.

"Labor, Capital and Class Struggle around the Built Environment in Advanced Capitalist Societies," Urbanization and Conflict in Market Societies. Ed. Kevin R. Cox. Chicago: Maaroufa Press, 1978.

- The Limits to Capital. Chicago: University of Chicago Press, 1989.

"On countering the Marxian myth - Chicago style." Comparative Urban Research 6.2 (1978) 28-45. 
"The Place of Urban Politics in the Geography of Uneven Capitalist Development." The Urbanization of Capital. Baltimore: John Hopkins Press, 1985. 125-164.

Social Justice and the City. London: Edward Arnold, 1973.

The Urban Experience. Baltimore: John Hopkins, 1989.

"The Urban Process under Capitalism: A Framework for Analysis." Urbanization and Urban Planning in Capitalist Society. London: Metheun, 1981. 91 .

Hatch, Walter. "City Limits. Seattle Times Special Report" Seattle: May 1989.

Untitled news article on Vision Seattle. U.p.., U.d...

Hausrath, Linda L. "Economic Basis for Linking Jobs and Housing in San Francisco." Journal of the American Planning Association 54.2 (1988): 210-216.

Hill, G. Richard. "Seattle's Voters Cap Downtown Development." Urban Land. 48.8 (1989): 32-33.

Hill, Greg. Electrical Energy Demand Growth in Seattle's Business District Impacts and Policy Alternatives. Scientists/Citizens Organized on Policy Issues. Seattle: 1982

Horan, Cynthia. "Beyond Governing Coalitions: Analyzing Urban Regimes in the 1990's." Journal of Urban Affairs 13.2 (1991) 119-135.

Horseley, John. "Pugetoppling Can the region diversity the second time around?" Planning 49.2 (1983): 30-33.

Huffman, Jr. Forest E. and Marc T. Smith. "Market Effects of Office Development Linkage Fees. Journal of the American Planning Association. 54.2 (1988): 217-224.

Hunter, Floyd. Community Power Structure. Chapel Hill: University of North Carolina Press, 1953. 
Community Power Succession: Atlanta's Policy-Makers Revisited. Chapel Hill: University of North Carolina Press, 1980.

Jackson, Peter \& Susan J. Smith. Exploring Social Geography. London: George Allen \& Unwin, 1984.

Keating, W. Dennis. "Linking Downtown Development to Broader Community Goals: An Analysis of Linkage Policy in Three Cities." Journal of the American Planning Association $\mathbf{5 2 . 2}$ (1986): 133-41.

Keating, W. Dennis and Norman Krumholz. "Downtown Plans of the 1980s" The Case for More Equity in the 1990s." Journal of the American Planning Association 57.2 (1991): 136-152

Lassar, Terry Jill "Great Expectations: The Limits of Incentive Zoning," Urban Land 49.5 (1990): 12-15.

Carrots and Sticks: New Zoning Downtown. Washington, D.C.: Urban Land Institute, 1989.

Lawless, The Evolution of Spatial Policy. London: Pion Limited, 1986.

Lefebre, Henri. Critique of Everyday Life. London: Routledge Chapman \& Hall, 1991.

Everyday Life in the Modern World. Trans. Sacha Rabinovitch. New Brunswick: Transaction Books, 1984.

The Production of Space. Trans. Donald Nicholson-Smith, London: Blackwell, 1991.

The Sociology of Marx. New York: Columbia University Press, 1982.

Space: "Social Product and Use Value," Critical Sociology: European Perspective. New York: Irvington Publishers, 1977.

Logan, John R. "Growth, Politics, and the Stratification of Places." American Journal of Sociology 84.2 (1978): 404-415. 
"Notes on the Growth Machine: Toward a Comparative Political Economy of Growth." American Journal of Sociology 82.2 (1976): 349-352.

Logan, John R. and Harvey L. Molotch. Urban Fortunes. Berkeley: University of California Press, 1987.

Logan, John R. and Todd Swanstom. Beyond the City Limits: Urban Policy and Economic Restructuring in Comparative Perspective. Philadelphia: Temple University Press, 1990.

Lukes, Steven. Power: A Radical View. London: Macmillan, 1974.

MacColl, E. Kimbark. The Growth of a City. Portland, Or.: Georgian Press, 1979.

The Shaping of a City. Portland, Or.: Georgian Press, 1976.

MacDonald, Norbert. Distant Neighbors. A Comparative History of Seattle and Vancouver. London: University of Nebraska Press, 1988.

Miller, Delbert. International Power Structure: Comparative Study of Four World Cities. Bloomington Indiana University Press, 1970.

Mollenkopf, John. The Contested City. Princeton: Princeton University Press, 1983.

"Paths toward the Post-Industrial Service City: the Northeast and the Southwest." R. Burchell and D. Listokin, eds. Cities Under Stress. New Brunswick, N.J.: Rutgers, 1981. 77-113.

A Phoenix in Ashes: The Rise \& Fall of the Koch Coalition in New York Politics. Princeton: Princeton University Press, 1992.

"The Postwar Politics of Urban Development." Politics and Society 5 (1975): 247-296.

Power. Culture \& Place: Essays on New York City. Beverly Hills: Sage, 1989. 
Mollenkopf, John and Manuel Castells. Dual City: The Restructuring of New York. Beverly Hills: Sage, 1991.

Molotch, Harvey. "Capital and Neighborhood in the United States," Urban Affairs Quarterly 14.3 (1978/1979): 289-312.

"The City as a Growth Machine: Toward a Political Economy of Place." American Journal of Sociology, 82.3 (1976): 309-332.

"Logan on Molotch and Molotch on Logan," American Journal of Sociology 82(2): 309-332.

"Strategies and Constraints of Growth Elites," Business Elites and Urban Development: Case Studies and Critical

Perspectives. Ed. Scott Cummings. Albany: SUNY Press, 1988: 25-47.

John Logan. "Tensions in the Growth Machine: Overcoming Resistance to Value-Free Development." Social Problems 31.5 (1984): 483-499.

"Urban Dependencies: New Forms of Use and Exchange in U.S.

Cities," Urban Affairs Quarterly 21.2 (1985/1986): 143-169.

Netter, Edith M. "An Uncertain Future for Historic Preservation Ordinances." Urban Land 46.7 (1987): 34-35.

Nicholas, Jonathan. "Earl of the Eastside. Can developer Bill Scott bring westside clout to the other side of town?" Northwest Magazine. The Sunday Oregonian. Portland: October 21, 1990.

O'Connor, James. The Fiscal Crisis of the State. New York: St Martin's Press, 1973.

Peirce, Neal. The Peirce Report. Puget Sound in the '90's: the challenge of growth, the cost of sprawl, the danger in failing to act." Reprinted from Seattle Times. October 1-8, 1989.

Perry, David. C. and Alfred J. Watkins. The Rise of the Sunbelt Cities. Beverly Hills: Sage, 1977.

Peterson, Paul E. City Limits. Chicago: The University of Chicago Press, 1981. 
Polsby, Nelson. Community Power and Political Theory: A Further Look at Evidence and Inference. 2nd rev. ed. New Haven: Yale University Press, 1980.

Pomeroy, Earl. The Pacific Slope: A History of California, Oregon, Washington, Idaho. Utah and Nevada. New York: Alfred A. Knopf, 1965.

Porter, Douglas R. and Lassar Terry Jill "The Latest on Linkage" Urban Land 47.12 (1988): 7-11

Protasch, William and Mark Baldassare. "Growth Policies and Community Status: A Test and Modification of Logan's Theory." Urban Affairs Quarterly 18(3) 397-412.

Ratcliff, Richard E. and Mary Elizabeth Gallagher and Kathyrn Strother Ratcliff. "The Civic Involvement of Bankers: An Analysis of the Influence of Economic Power and Social Prominence in the Command of Civic Policy Positions." Social Problems 26.3 (1979): 298-312.

Rose, David C. "City Profile: Seattle." Cities 7.4 (1990): 283-288.

Rosenthal, Donald B. Urban Revitalization. Urban Affairs Annual Reviews 18. Beverly Hills: Sage, 1980.

Ryan, Beatrice, Rich Yukubousky, Philip Sherburne, Rona Zevin and John Linner. "Insider's view. The big picture." Planning 49.2 (1983): 22-29.

Ryan, Dennis. "Lay of the land" Planning 49.2 (1983): 18-21.

Sagalyn, Lynne B. "Explaining the Improbable: Local Redevelopment in the Wake of Federal Cutbacks." Journal of the American Planning Association 56.4 (1990) 429-441.

Sale, Roger. Seattle: Past to Present. Seattle: University of Washington Press, 1976.

Sanders, Heywood T. "Urban Renewal and the Revitalized City: A Reconsideration of Recent History." Urban Revitalization Urban Affairs Annual Reviews 18 Ed. Donald B. Rosenthal.Beverly Hills: Sage, 1980. 103-126. 
Saunders, Peter. Social Theory and the Urban Question. New York: Holmes and Meier, 1981.

Urban Politics: a sociological interpretation. London: Hutchinson, 1978.

Savitch, H. V. and John Clayton Thomas. Big City Politics in Transition. Urban Affairs Annual Reviews 38. Newbury Park, Ca.: Sage, 1991.

Sawers, Larry. "New Perspectives on the Urban Political Economy," Marxism and the Metropolis. Eds. William Tabb and Larry Sawers. New York: Oxford University Press, 1978.

Sawers, Larry and W. Tabb, eds. Sunbelt/Snowbelt. New York: Oxford University Press, 1984.

Sherburne, Phillip. "An untapped resource." Planning February, 49.2 (1983): 26-27.

Sidron, Mark H. Middle-class Politics in Seattle BA Thesis, Harvard, 1973.

Simmie, James. "Planning Theory and Planning Practice: An Analysis of the San Francisco Downtown Plan." Cities. 4.4 (1987): 304-324.

Smith, Michael Peter, ed. After Modernism: Global Restructuring \& the Changing Boundaries of City Life. New Brunswick: Transaction Books, 1992.

Breaking Chains: Social Movements and Collective Action (Comparative Urban and Community Research Series: Vol. 3) New Brunswick: Transaction Books, 1990.

Ed. Cities in Transformation: Class, Capital, and the State. Urban Affairs Annual Review 26. Beverly Hills: Sage, 1984. The City and Social Theory. New York: St. Martin's Press, 1979.

City. State, and Market. New York: Basil Blackwell, 1988. 
"Critical Theory and Urban Political Theory." Comparative Urban Research 7.3 (1980): 5-23.

Power. Community \& The City: Comparative Urban and

Community Research. Vol. 1. New Brunswick: Transaction Books, 1988.

Smith, Michael Peter and Joe R. Feagin. The Capitalist City: Global Restructuring \& Community Politics. London: Blackwell, 1987.

Smith, N. and P. Williams, eds. Gentrification of the City. London: Allen and Unwin, 1986.

South, Scott J. and Dudley L. Poston, Jr. "The U.S. Metropolitan System: Regional Change, 1950-1970." Urban Affairs Quarterly 18,2 (1982) 187-206.

Spiedel, William. Sons of the Profits. or There's no Business Like Grow Business. The Seattle Story, 1851-1901. Seattle: Nettle Creek Publishing Co., 1967.

Squires, Gregory D. "Partnership and the Pursuit of the Private City." Urban Affairs Annual Reviews 39 Newbury Park, Ca.: Sage, 1991. 196-221.

Stone, Clarence N. "City Politics and Economic Development: Political Economy Perspectives." Journal of Politics 46.1 (1984): 286-299.

"Community Power Structure - A Further Look." Urban Affairs Quarterly 16.4 (1976): 505-515.

Economic Growth and Neighborhood Discontent. System Bias in the Urban Renewal Program of Atlanta. University of North Carolina Press, 1976.

"Efficiency vs. Social Learning." Policy Studies Review 4.(Feb. 1985): 484-96.

Regime Politics: Governing Atlanta, 1946-1988. Lawrence, University of Kansas Press, 1989. 
"Social Stratification, Non-Decision-Making and the Study of Community Power." American Politics Quarterly 10.3: (1982): 275-302.

_ "Systemic Power in Community Decision Making: A Restatement of Stratification Theory." American Political Science Review 74.3 (1980): 978-990.

"Systemic Power in Community Decision Making: A Restatement of Stratification Theory," American Political Science Review 74,3 (1980): 159-179.

Urban Policy and Politics in a Bureaucratic Age. Englewood Cliffs, NJ.: Prentice-Hall, 1979.

Stone, Clarence N., Marion E. Orr, and David Imbroscio. "The Reshaping of Urban Leadership in U.S. Cities: A Regime Analysis." Urban Life in Transition. Urban Affairs Annual Reviews 39 Newbury Park, Ca.: Sage, 1991. 222-239.

Stone, Clarence N. and Heywood T. Sanders. The Politics of Urban Development. Lawrence: University Press of Kansas, 1987.

Sullivan, Arthur M. Urban Economics. Homewood, II: Irwin, 1990.

Swanstrom, Todd. Crisis of Growth Politics: Cleveland, Kucinich and the Challenge of Urban Populism. Philadelphia: Temple University Press, 1985.

Tabb, William and Larry Sawers, eds. Marxism and the Metropolis. New York: Oxford University Press, 1978.

Thomlinson, Ralph. Urban Structure: The Social and Spatial Characteristics of Cities. New York: Random House, 1969.

Tilden, Freeman. "Portland, Oregon: Yankee Prudence on the West Coast." World's Work 60.10 (1931): 34-40.

University of Washington, Institute of Governmental Research. Inner-City Revitalization and Displacement: The New Urban Future. Seattle: University of Washington, 1979.

Downtown Development Washington, DC.: Urban Land Institute, 1981. 
Joint Development. Washington, DC.: Urban Land Institute, 1979.

Urban Waterfront Handbook. Washington, DC.: Urban Land Institute, 1983.

Verba, Sydney and Norman H. Nie. Participation in America. New York: Harper \& Row, 1972.

Vision Seattle. The Vision Seattle Issue Agenda. A working statement of the beliefs and ideals of the combined Vision Seattle membership and Board of Directors. Seattle: Vision Seattle, 1990.

Wirt, Frederick M. Power in the City: Decision Making in San Francisco, Berkeley: University of California Press, 1974.

Woods, Julia A. "Seattle's Friday Afternoon Massacre." Planning 45.4 (1979): 6-7.

Yates, Douglas. The Ungovernable City: The Politics of Urban Problems and Policy Making. Cambridge: MIT Press, 1977.

Yukubousky, Richard. "On the road." Planning February, 124 (1983): 24-26.

Zevin, Rona and John Linner. "Livable but still lacking." Planning February (1983): 27-28.

F. Interviews

Abbott, Norm. Portland. July, 1991.

Angel, Joseph,. Portland. July, 1991.

Barnett, Beverly. City of Seattle. September, 1990.

Bauer, Steve. City of Portland. December, 1991.

Bonner, Ernie. Portland. July, 1991.

Burki, Mary. Seattle. March, 1991.

Butler, Doug. Portland Development Commission. March, 1992.

Champion, Jeff. Portland. June, 1991. 
Clark, Donald. Housing Authority of Portland. February, 1991.

Clay, Robert. City of Portland. January, 1991.

Clemons, Mark. Portland Development Commission. March, 1992.

Copca, Chris. Portland Development Commission. June, 1991.

Crandall, George. Portland. June, 1991.

Davis, Gordon. Portland. June, 1991.

DeMaster, Jean. Transition Projects (name?). May, 1992.

Denny, Brewster. July, 1991.

Dobson, Linda. City of Portland. March, 1991.

Dotterrer, Steve. Portland. July, 1991.

Duchek, Bill. City of Seattle. July, 1990.

Forester, Richard. Portland. April, 1992.

Fry, Peter. Portland. July, 1991.

Galbreath, Samuel. Portland. January, 1991.

Gisvold, Dean. Portland, June, 1991.

Harper, Dennis. Portland. June, 1991.

Harrison, Michael. City of Portland. April, 1991 and June, 1991.

Hatch, Walter. Seattle Times. September, 1990.

Hewitt, David. Seattle. March, 1991.

Kilgore, Judith. City of Seattle. March, 1991.

Kraabel, Paul. Seattle City Council (name?) July, 1991.

Lindberg, Mike. Portland City Council. May, 1992.

Lindsey, Betsey (sp?). Portland. June, 1991.

McLaughlin, Anne (sp?). City of Portland. August, 1991.

McPherson, Linda. City of Portland. June, 1991.

Meier, Dennis. City of Seattle. July, 1990 and June, 1991. 
Meier, Richard. Portland. February, 1991.

Norton, Skip. Bassetti, Norton, P.C. Seattle. March, 1991.

O'Hiser, Rodney. City of Portland. June, 1991 and January, 1992 and April, 1992.

Owens, James. Portland. March, 1991.

Pearce, James. City of Seattle. July, 1990.

Sharpe, Sumner. Portland. May, 1991 and April, 1992.

Shiels, Roger. Portland. January, 1991.

Smith, Dean. Portland. March 1991.

Solheim, Al. Portland. April, 1992.

Steffey, Dan. City of Portland. January, 1992

Steinbrueck, Peter. Seattle. September, 1990.

Strachan, Margaret. Portland. April, 1992.

Strosahl, Pat. Seattle. March, 1991.

Tenny, Ed Portland.

Tillett, Paddy. Portland. March, 1991, and October, 1991.

Tweete, Cheryl. Portland Development Commission. July, 1991.

Waehrer, Edgar. City of Portland. September, 1991. 
APPENDIX

\section{KEY PLAYERS}

\section{PORTLAND}

The most influential members of the downtown community have remained on the scene since the beginning of the study period with few exceptions. The most notable departure has been that of Bill Roberts who saw the implementation of the Transit Mall, the single defining project in downtown Portland. Mayor Goldschmidt (1973 - 1979) reappeared as Governor Goldschmidt (1987 -1990).

The Association for Portland Progress (APP) has a convenient list of 75 members. These members may join by invitation only and are expected to participate in APF's programs and to contribute to a special assessment to provide an extra level of city services from civic promotion to sanitation to police patrol. The most prominent developers/property owners are: Doug Goodman, Melvin Mark Jr., William S. (Bill) Naito, Patrick R. Prendergast, John Russell, and Jack Saltzman. Others are officials of big development concerns such as Harriet Sherburne, Olympia \& York; Denis O'Neill, Cornerstone (Riverplace); Larry Troyer, Lloyd Center; and [formerly] William C. Scott, Pacific Development Inc. (owner of most of the remainder of the Lloyd District). The two big banks, First Interstate and U.S. Bank, are represented by Robert Ames and Edmund P. Jensen. 
Harry Demorest, Managing Partner of Arthur Andersen \& Co. and former chair of PDC; Robert Frasca, partner at ZGF architectural firm; Stephen T. Janik, Partner at Ball, Janik \& Novack law firm; and Jon R. Schleuning, SRG Partnership are all professionals with intimate ties to the business and development end of downtown development. Retailers include Meier \& Frank, Nordstrom and Rouse. Hotels are also represented. Media institutions include the The Qregonian, and KATU, KPTV, KOIN, and KGW television. Other institutions include the gas company, the Portland Trail Blazers of the National Basketball Association, and Portland State University. The Chamber of Commerce or the Port of Portland may be involved on a limited basis.

Not members of this club are those consultants such as Roger Shiels and Doug Obletz who represent north of Burnside interests and Peter Fry who represents the East Portland interests. It should be noted that the Central Eastside Industrial Council has little tiein. The Association for Portland Progress, which once included only downtown westside interests, has now expanded to include the Lloyd District but no Central Eastside business interests. However, Vern . Ryles of the Central Eastside is the new chair of PDC.

Most importantly, the Portland Development Commission is a player in any urban renewal district. And urban renewal districts stretch from Union Station to Cornerstone, from the South and North Park Blocks to Lloyd District and Central Eastside (that is, just about everywhere.) 
Community action is usually limited by function, for example, the League of Women Voters was concerned about downtown parking issues. The Riverfront for People group organized to fight for the 15 move. The Downtown Community Association and Goose Hollow are the only relevant neighborhood groups as the Burnside Community Council no longer exists and no neighborhood group exists for the Lloyd District. Individuals such as Ray Polani, head of Citizens for Better Transit, is one of a handful of individuals without professional or business connections, who have participated in policy debates. George Crandall, who is associated with the local chapter of the A.I.A., has paticipated in many issues.

Although both Seattle and Portland have downtown business associations and powerful private businessmen, local government in Portland is much more involved in redevelopment. The city has close ties with private interests and local social activists are also tied into city policy.

\section{SEATTLE}

In April, 1987, the Seattle Times published a special report, "Who runs Seattle. - Facts and opirions about People, Politics and Power in the City." The newspaper gathered over 400 names before winnowing these into a list of 10 influentials, 10 more in a second tier, and dozens of names in varying fields. The top ten were: Jim and John Ellis, Jon and Judy Runstad, Herman Sarkowsy, Frank Shrontz (Boeing), Martin Selig, Ned Skinner, Andrew Smith (Pacific NW Bell); G. Robert Truex (Ranier Bank), George Weyerhauser, Bagley 
and Virginia Wright. The top twenty individuals or businesses mentioned in interviews were: Jim Ellis; Boeing; Mayor Royer; the Seattle Times and Seattle Post-Intelligencer newspapers; Rainer Bank; Seafirst Bank; Seattle City Council; Metro; KING, KIRO and KOMO television; Weyerhaeuser; Pacific NW Bell; Seattle University; Jon and Judy Runstad; Seattle Chamber of Commerce; King County; Ned Skinner; Nordstrom and Burlington Northern railroad. The Seattle Times grouped these forces into politicians, bureaucrats, the establishment, the banks, the developers, the media, the culture elite, the sports elite, the clubs, networkers, and minorities and women. The Downtown Seattle Association represents the establishment, the developers, and the media.

However, controversies in Seattle have brought forth counterforces. These have been primarily neighborhood, housing or reform civic groups. The most prominent groups are Allied Arts, the Municipal League, Seattle Displacement Coalition, and Vision Seattle. Previous groups have included Citizens for an Alternative Plan, People for an Open Westlake and CHECC.

Seattle City government occupies a middle ground between the downtown establishment and the neighborhoods: The Office of Policy Evaluation (OPE), Office of Long-range Planning (OLP), and Land Use and Transportation Plan (LUTP), and the Department of Community Development (DCD) report to the mayor [Wes Uhlman, Charles Royer and now Norm Rice]. The Seattle City Council reviews the Mayor's recommended policies. Jim Street and Paul Kraabel negotiated many of the decisions regarding land use. 


\section{KEY PLAYERS IN EACH CITY}

The following are the key players in each of the decisions discussed within this dissertation.

\section{PORTLAND}

\section{Chapter III: From Downtown Plan to Central City Plan}

Edwin W. Steidle (Meier \& Frank department store); Bill Roberts (Lipman's department store); Glen Jackson (Oregon Highway Department); and Ira Keller (PDC); Downtown Committee; CH2MHill; Dean Gisvold, Citizen's Advisory Commission; Portland Chapter of the AIA.; Bob Baldwin, Multnomah County planner; Portland City Commissioner Lloyd Anderson; and City Planner Rod O'Hiser.

\section{Central City Plan}

Strachan era

Commissioner Margaret Strachan; Pre-planning Committee members PDC Executive Director Patrick LaCrosse, Planning Bureau Director Terry Sandblast, William Wyatt (APP) and Donald Lengacher (CEIC); Strachan confident architect Donald Statsney; consultants Don Barney and Gordon Davis; Citizen's Steering Committee members; PDC staff; Planning Commission and Bureau of Planning ex officio members; Citizen Functional Advisory Committees; George Crandall, Will Martin and Paddy Tillett, Urban Design Advisory Team; Vern Ryles, Central Eastside Industrial Council; Ernie Bonner, Riverfront for People; Plan Manager Dean Smith and City Planner Rod 
O'Hiser; Planning Director Norm Abbott; and " 10,000 " Portland participants in public Design Events One and Two.

Blumenauer era

Those listed above and Michael S. Harrison, Portland Planning Bureau; Joseph Angel and other members of the Planning Commission; attorneys Steve Janik and Timothy Ramis; housing activists; Commissioners Earl Blumenauer and Mike Lindberg and Mayor J.E. "Bud" Clark, City Council; and Jane Cease, Metro JPac Committee.

Chapter V. Portland Morrison Street Project

Cadillac Fairview

Mayor Goldschmidt; Portland Development Commission staff; Office of Plarining and Development staff; Linden Bronan, Society of Industrial Realtors; Bill Naito; Robert Frasca; Don Barney; the Oregonian; Homeowners Association; Martin Gix, Downtown Community Association; Portland Chapter of the AIA and Ed Tenny, Save Our Liveable Downtown.

Rouse Phase

Doug Obletz; Morrison Project Selection Advisory Committee Joan Smith, Planning Commission, Pat LaCrosse, PDC, Robert Franz, Pacwest Bancorp, Jon Schleuning, AIA and Bill Roberts; the Design Commission (skybridges); Diane Spies (condemnation suit) and Tom Dennehey (tax increment funding critic). 
Chapter Vil: From Skid Road to North Dowtown

Downtown Plan

Robert Baldwin; George 'Bing' Sheldon; Dean Gisvold and other Downtown Plan actors; Irving Shandler; Bureau of Human Resources; and the Downtown Housing Advisory Committee.

\section{Plan}

Northwest Natural Gas; U.S. Bank and other big property owners; small time entrepreuners; historic preservationists; social service agencies; the Asian community; Office of Planning and Development; and Bureau of Planning (Karen Kramer).

Mayor's 12 Point Plan

Mayor Bud Clark, BCD executive Don Steffey, and PDC Executive Director Pat LaCrosse; Donald E. Clark Burnside Consortium (renamed Central City Concern); Jean DeMaster, Burnside Projects; Michael Stoops, Burnside Community Concern; Union Station Business Community Association; and Bill Naito.

Central City Plan/North Downtown

PDC (development limitations); Don Clark/Roger Shiels (ClarkShiels agreement).

Challenge to PDC

Barney \& Worth; City/County Housing Management Association. 
River District

Bob Ames, First Interstate Bank; Roger Breezley, U.S. Bancorp; John Carroll, Prendergast Associates; Jim Edwards, Hillman Properties Northwest; North Downtown Consortium; Paul Hathaway, Chamber of Commerce; Don Magnusen, Union Station Task Force (PDC); Bill Naito; Pat Prendergast; Robert Ridgley, Northwest Natural Gas Company; Mike Thorne, Port of Portland; Doug McGregor, PDC; (Prepared by Shiels \& Obletz and Zimmer Gunsul Frasca Partnership)

Central City Plan

PDC; Businesses represented by Roger Shiels; Don Clark, Central City Concern; and Bureau of Planning.

\section{Seattle}

\section{Chapter IV: Land Use and Transportation Plan}

Downtown Seattle Association (DSA, iormerly Central Association and Downtown Seattle Development Association); Seattle Chapter of the AIA; Allied Arts; Sierra Club; Citizens' Alliance for Urban Seattle; housing activist organizations such as the Downtown Neighborhood Alliance; Mayor's Advisory Group, and the League of Women Voters.

Land Use and Transportation staff; Paul Kraabel, chair of the Urban Redevelopment Committee of Seattle City Council. 
Citizens' Alternative Plan

DSA/Citizens for a Better Downtown, i.e. developers, banks, contractors, manufacturers, real estate utilities, architects and engineers, hotels, business associations, lawyers, accountants, retailers, and unions; Ted Inkeley, Peter Steinbrueck, Pat Stroshal, Citizens for an Alternative Plan; Vision Seattle; Paul Schell, Cornerstone; Mayor Royer and Seattle City Council members Jim Street and Virginia Galle.

Post CAP

Downtown Plan Revision Advisory Committee: John Phillips, Phillips and Wilson; Dorm Anderson, NBBJ; Steven Arai, Arai/Jackson; Sue Cary, Southeast Effective Development; A.M. Clise, Clise Agency; Ken Cole, Pioneer Human Services; Jerry Ernst, TRA; John Fox, People for Downtown Housing; Joan Gamble, Puget Sound Power \& light; John Gibson, Gibson Economics; Tom Graff, Allied Arts; Jim Greenfield, Seattle Goodwill Games; Grace Jansons; Brian Jennison; Mary McCumber; Melcidy McCrutcheon; Gary Schweikhardt; Peter Steinbrueck; Lucy Steers; Sue Taoka; Steve Trainer, Wright Runstad \& Co.; Tom Walsh, Foster Pepper \& Shefelman; Carol Warren, League of Women Voters, Mark Wheeler; Lane Powell; and Moss Miller. 
Chapter Vl: Seattle Westlake Mall Project

Westlake Mall/Uhlman

Mayor Wes Uhlman, City Council, City Planning staff, Central Business Association Cultural and Beautification Committee, Seattle Chapter of the AIA, Allied Arts, CHECC, and Citizens and Merchants against the Westlake Project.

Mondev phase

Mayor Charles Royer; Westlake Advisory Committee; Westlake Development Authority; Seattle Art Museum/Royer; and Citizens for an Alternative at Westlake (CAW)/Nictor Steinbrueck and Folke Nyberg.

Rouse phase

Mayor Charles Royer; Westlake Proposal Evaluation Committee; Gang of Five, CAW; City Attorney Doug Jewett; and the Seattle City Council.

Demolition phase

People for an Open Westlake (organized by League of Women Voters, Allied Arts, 13,000 petition signers)/Margaret Pageler; David Brewster; Patricia Denny and Brewster Denny; and Mayor Charles Royer. 
Chapter VIII: Residential Displacement in Downtown Seattle

Housing displacement

DSA, Denny Regrade Property Owners, property owners such as West Coast Paper Profit Sharing Trust, Harbor Properties, Inc., Block 60 Associates, and Sterling Recreation Organization; Downtown Neighborhood Alliance; People for Downtown Housing; International District Housing Alliance; Plymouth Housing Group; Emergency Housing Coalition; Downtown Neighborhood Alliance; Elder Citizens Coalition of Seattle-King County; King County Union Retirees;

Downtown Human Services Council; John Fox and Rev. David Bloom, Seattle Displacement Coalition; and Church Council of Greater Seattle; Market Residents Association; Pike Place Market Constituency; Pike Place Merchants Association; Pike Place Market Preservation \& Development Authority; Belltown Coalition; Denny Regrade Community Council and Interim Community Development Association. 